\title{
Progress ToWARD The SYNTHESIS OF LABELED Derivatives of THE CySTIC Fibrosis DRUG, IVACAFTOR
}

\author{
By: \\ Salma Elmallah \\ Bachelor of Science, Pharmacy, \\ Alexandria University, Egypt, 2009 \\ A thesis presented to Ryerson University \\ in partial fulfillment of the requirements for the degree of \\ Master of Science in the program of \\ Molecular Science
}

Toronto, Ontario, Canada, 2012

(C) Salma Elmallah 2012 


\section{Author's Declaration}

I hereby declare that I am the sole author of this thesis. This is a true copy of the thesis, including any required final revisions, as accepted by my examiners.

I authorize Ryerson University to lend this thesis to other institutions or individuals for the purpose of scholarly research.

I further authorize Ryerson University to reproduce this thesis by photocopying or by other means, in total or in part, at the request of other institutions or individuals for the purpose of scholarly research.

I understand that my thesis may be made electronically available to the public. 


\begin{abstract}
Progress Toward The Synthesis of Labeled Derivatives of The Cystic Fibrosis

DRUG, IVACAFTOR
\end{abstract}

Salma Elmallah

Master of Science, Molecular Science, Ryerson University, 2012

Cystic fibrosis (CF) is one of the most common genetic diseases, affecting approximately 70,000 people worldwide causing severe complications and often leading to early death. CF is caused by a mutation in the gene encoding for the cystic fibrosis transmembrane conductance regulator (CFTR) protein which is responsible for fluid and ion transport through epithelial membranes maintaining the formation of a thin slippery mucous layer. CFTR mutations either lead to a trafficking defect where the CFTR protein does not reach the plasma membrane or a gating defect where CFTR protein at the plasma membrane does not function properly. Treatment of cystic fibrosis usually addresses the symptoms to overcome the complications of the disease such as pneumonia, lung infections, pancreatitis, maldigestion and infertility. Vertex pharmaceuticals has been interested in developing small molecules that have the ability to interact with mutated CFTR proteins, aiding in their delivery to the cell membrane and/or restoring their channel function. VX-770 is an orally bioavailable potentiator that has the ability to improve the gating activity and increasing the open probability of CFTR protein in patients carrying the G551D mutation. VX770, Ivacaftor, was recently approved by the US FDA after showing very good improvements in the lung function in CF patients with good safety profile. Our research is focusing on the synthesis of VX770 under mild conditions and formation of labeled derivatives to help in the understanding of its exact mode of action. Different methods were developed toward the synthesis of the two main components, LHS and RHS, of VX770 by using less harsh conditions for a short period of time. We were successfully able to make two photoaffinity labeled derivatives, aryl azide and benzophenone derivatives, which will be beneficial in tracking the drug molecule and revealing the exact site of interaction between the drug and the protein. Synthesis of VX770 fragments was is another focus of interest in our research as they will provide us with information about the best positions for further derivatization. 


\section{Acknowledgements}

I would like to start off by expressing my sincere and deepest gratitude to my supervisor, Dr. Russell Viirre, for giving me the opportunity to pursue my graduate studies in his lab. He has supported me throughout my research project with his continuous guidance, patience and expertise as he made my two years at Ryerson pass very smoothly. Not only was he a phenomenal mentor and supervisor, he was also really inspiring by his great knowledge and passion towards synthetic organic chemistry. One simply could not wish for a better supervisor.

I would like to thank my committee members; Dr. Robert Gossage and Dr. Andrew McWilliams for their help and expertise as well as everyone in the synthetic group at Ryerson for being such an amazing group.

Next, I would like to thank my research group. In my daily work, I was blessed with a fantastic,

cheerful, motivating group of people. I want to thank my past and present lab mates; Augusto Matarazzo, Bashar Alkhouri, Salman Ansari, Rob Denning and Vassilios Kanellis. You guys have made this experience really enjoyable and unforgettable.

Last but not least, I would like to thank my parents; Safinaz and Aly Elmallah for their continuous encouragement and support. I would also like to thank my sister, Sarah, my brother, Mahmoud, my brother-in-law, Sameh, and my cute little niece, Jana. I would have never been able to finish my master's without your understanding, encouragement and continuous support. 
Table of Contents:

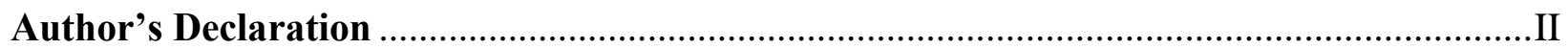

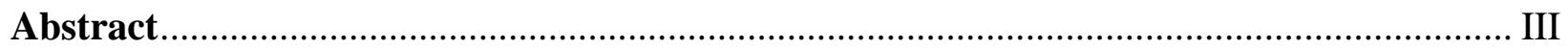

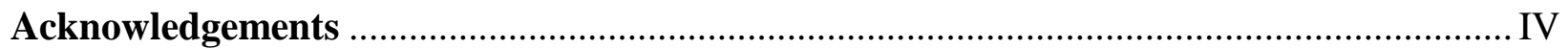

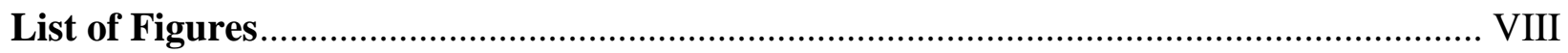

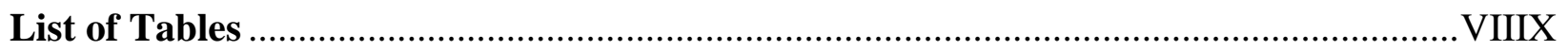

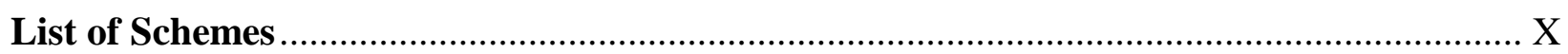

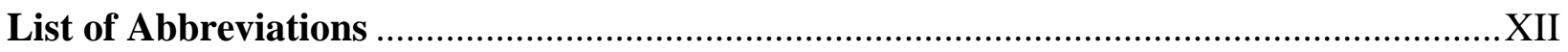

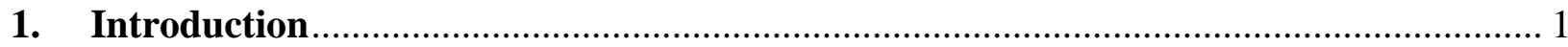

1.1. Background ........................................................................................................ 1

1.2. Structure and Function of CFTR Protein …………................................................. 2

1.3. CFTR Acting as A Multifunctional Protein ………….............................................. 3

1.4. Normal CFTR Protein Synthesis ............................................................................ 5

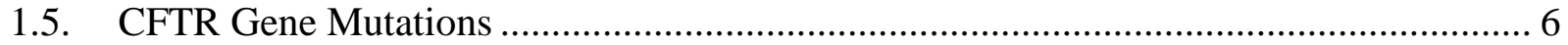

1.5.1. Class I Mutations: Defective Protein Production..................................................... 7

1.5.2. Class II Mutations: Defective Protein Processing ................................................ 9

1.5.3. Class III Mutations: Defective Regulation ...................................................... 10

1.5.4. Class IV Mutations: Defective Conduction ........................................................ 11

1.5.5. Class V Mutations: Reduced Synthesis .............................................................. 12

1.6. Symptoms of Cystic Fibrosis ............................................................................ 12

1.7. Towards The Treatment of CF ........................................................................... 13

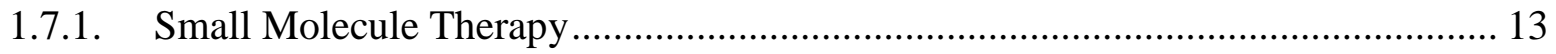

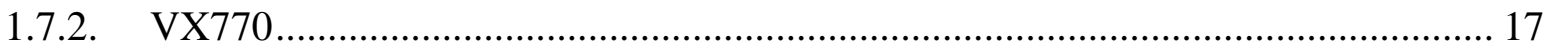

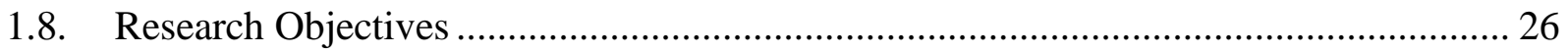

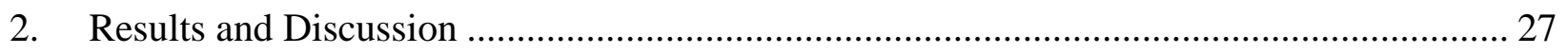

2.1. Towards the Synthesis of 4-oxo-1,4-dihydroquinoline-3-carboxylic acid (LHS) ......... 27

2.1.1. First Approach: Starting from phenylamino malonate ........................................ 27

2.1.2. Second Approach: Starting from ethoxymethylene Meldrum's acid ...................... 33 
2.1.3. Third Approach: Starting from Isatoic anhydride .......................................... 36

2.1.4. Fourth Approach: Tandem reduction-addition-elimination reaction..................... 38

2.2. Towards the Synthesis of 5-amino-2,4-di-tert-butyl phenol (RHS) ........................... 43

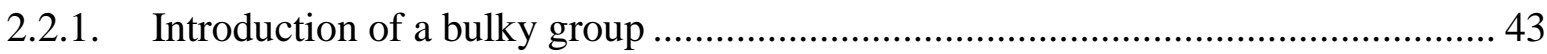

2.2.2. Introduction of an electron withdrawing group ............................................. 45

2.2.3. Blocking the ortho position on the RHS ...................................................... 47

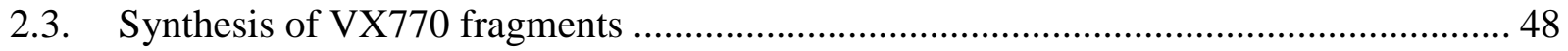

2.4. Towards the Synthesis of Labeled Derivatives ................................................... 51

2.4.1. Synthesis of Azido Photoaffinity Label ........................................................ 51

2.4.2. Synthesis of Benzophenone Photoaffinity Label ............................................ 53

2.4.3. Synthesis of Trifluoromethyl Diazirine Photoaffinity Label .............................. 55

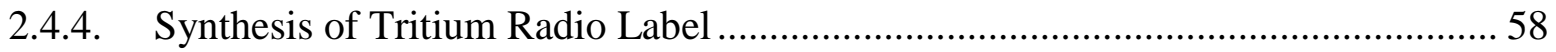

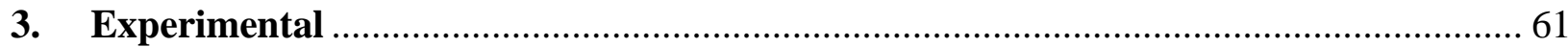

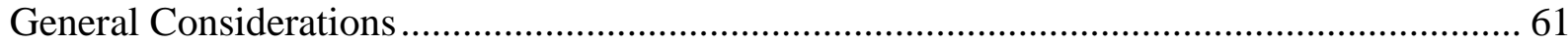

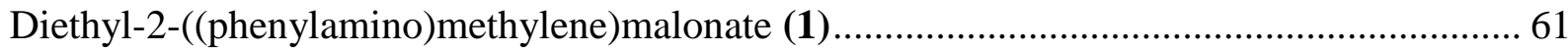

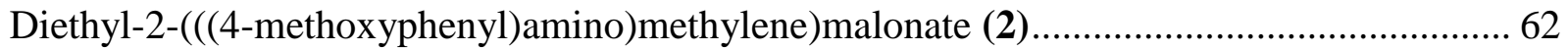

Diethyl-2-((N-(4-methoxyphenyl)acetamido)methylene)malonate (3) ............................... 63

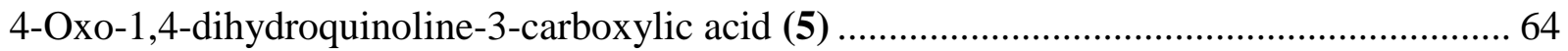

5-(((4-Methoxyphenyl)amino)methylene)-2,2-dimethyl-1,3dioxane-4,6-dione (7).............. 65

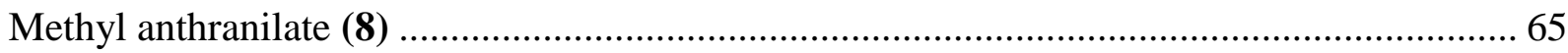

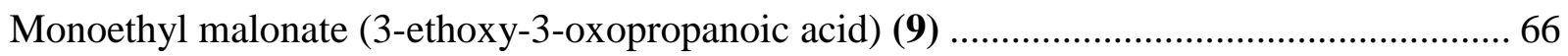

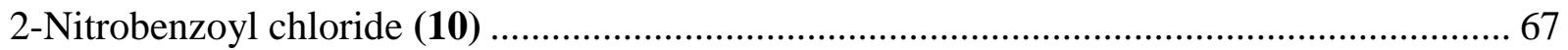

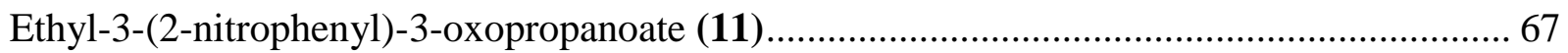

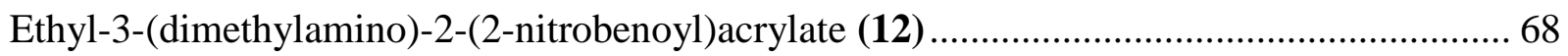

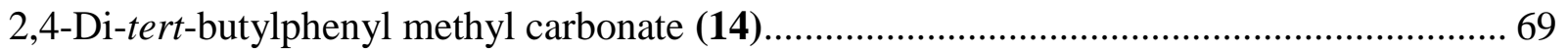

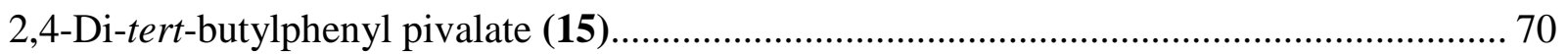

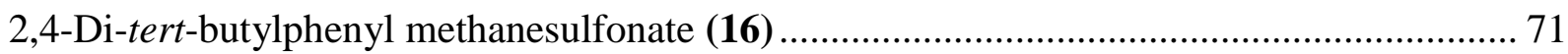

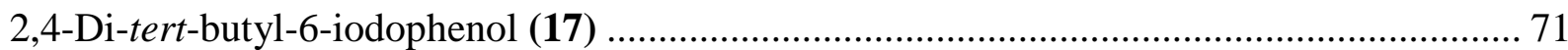

$N$-(4-(tert-butyl)phenyl)-4-oxo-1,4-dihydroquinoline-3-carboxamide (18) .......................... 72

$N$-(2-(tert-butyl)phenyl)-4-oxo-1,4-dihydroquinoline-3-carboxamide (19) ......................... 73

$N$-(3-hydroxyphenyl)-4-oxo-1,4-dihydroquinoline-3-carboxamide (20) ............................. 74

$N$-(4-butoxyphenyl)-4-oxo-1,4-dihydroquinoline-3-carboxamide (21).............................. 75

Ethyl-3-(dimethylamino)-2-(2,4,5-trifluorobenzoyl)acrylate (23) .................................... 77

(Z)-ethyl-3-(tert-butylamino)-2-(2,4,5-trifluorobenzoyl)acrylate (24) ................................ 78 
Ethyl-1-(tert-butyl)-6,7-difluoro-4-oxo-1,4-dihydroquinoline-3-carboxylate (25) ................ 78

Ethyl-7-azido-1-(tert-butyl)-6-fluoro-4-oxo-1,4-dihydroquinoline-3-carboxylate (26).......... 79

7-Azido-1-(tert-butyl)-6-fluoro-4-oxo-1,4-dihydroquinoline-3-carboxylic acid (27)............. 80

7-Azido-1-(tert-butyl)- $N$-(4-(tert-butyl)phenyl)-6-fluoro-4-oxo-1,4-dihydroquinoline-3-

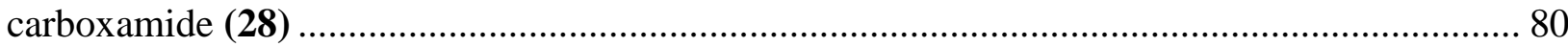

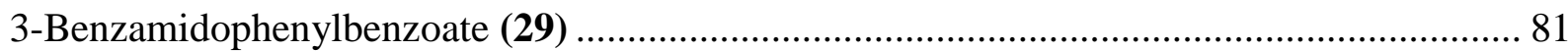

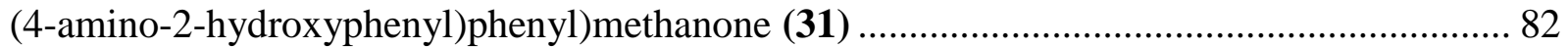

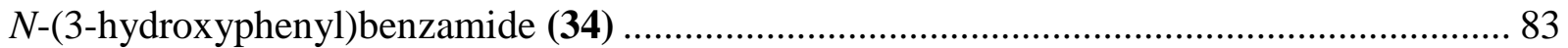

Diethyl-2-(((4-bromophenyl)amino)methylene)malonate (35) ........................................ 84

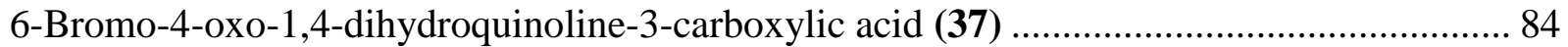

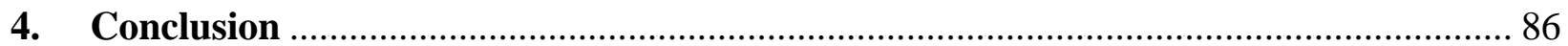

5. Appendix: NMR spectra $\left({ }^{1} \mathrm{H},{ }^{13} \mathrm{C},{ }^{19} \mathrm{~F}\right), \mathrm{HPLC}$ chromatograms....................... 88

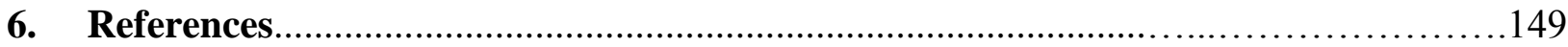




\section{List of Tables:}

Table 1: The functional classification of CFTR mutations................................................... 7

Table 2: Treatment effect of VX770 as compared to placebo ............................................ 21

Table 3: Different conditions attempted for the Friedel-Crafts acylation reaction.................... 29

Table 4: Different reagents used for the cyclization of compound 7 .................................. 35

Table 5: Different conditions tried for the synthesis of LHS starting from isatoic anhydride .... 36 


\section{List of Figures:}

Figure 1: Schematic diagram of the CFTR protein as best understood now ............................. 2

Figure 2: Diagram of multifunctional CFTR protein................................................... 4

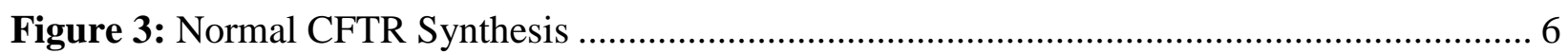

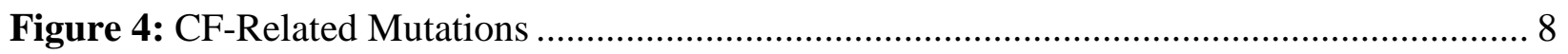

Figure 5: $\Delta$ F508 mutation; phenylalanine amino acid is deleted........................................ 10

Figure 6: G551D mutation; glycine amino acid is replaced by aspartic acid ........................ 11

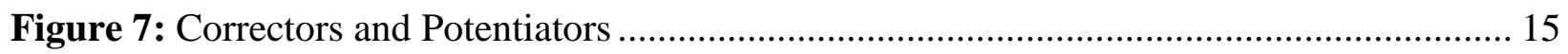

Figure 8: Corrector-Potentiator Hybrid Molecule ............................................................. 16

Figure 9: Structure of cyanoquinoline dual acting molecule (corrector/potentiator) ................ 17

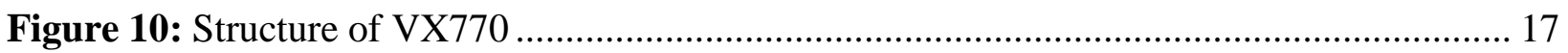

Figure 11: VX770 potentiating gating activity of CFTR. Mean $\mathrm{P}^{\circ}$ in presence of PKA and ATP alone (open bars) and with VX770 (filled bars) ...................................................... 19

Figure 12: Reactivity of photoaffinity labels ............................................................... 22

Figure 13: Reactive intermediates of; a) aryl azides, b) diazirines, and c) benzophenones ........ 23

Figure 14: Proposed mechanism of the addition reaction between methyl anthranilate and methyl propiolate to form quinolinone heterocycle ................................................ 38

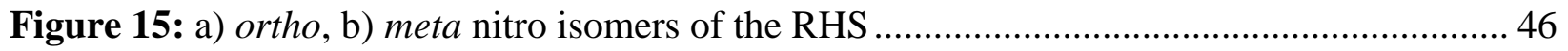

Figure 16: Main product of trifuoroacetylation-Fries reaction ....................................... 57 


\section{List of Schemes:}

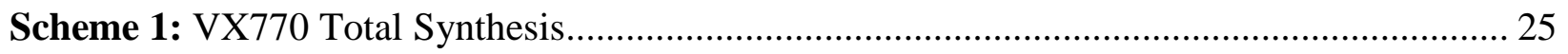

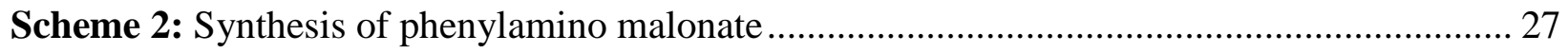

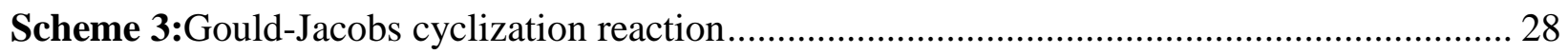

Scheme 4: Synthesis of diethyl-2-(((4-methoxyphenyl)amino)methylene)malonate ................... 30

Scheme 5: Synthesis of diethyl 2-((N-(4-methoxyphenyl)acetamido)methylene)malonate ........ 31

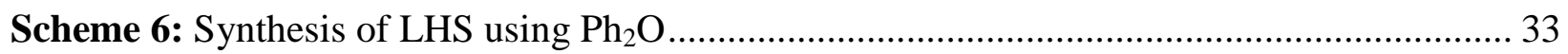

Scheme 7: Different ways for the synthesis of 5-(((4-methoxyphenyl)amino)methylene)-2,2dimethyl-1,3-dioxane-4,6-dione ..................................................................................... 34

Scheme 8: Synthesis of quinolinone starting from isatoic anhydride ......................................... 36

Scheme 9: Synthesis of methyl anthranilate and attempts for making quinolinone compound .. 37

Scheme 10: Synthesis of quinolinone via tandem reduction-addition elimination reaction ......... 39

Scheme 11: Synthesis of monoethyl malonate ..................................................................... 39

Scheme 12: Synthesis of 2-nitrobenzoyl chloride ..................................................................... 40

Scheme 13: Modified method for the synthesis of ethyl 3-(2-nitrophenyl)-3-oxopropanoate … 41

Scheme 14: Formation of ethyl-1-hydroxy-4-oxo-1,4-dihydroquinoline-3-carboxylate .............. 42

Scheme 15: Synthesis of 2,4-di-tert-butylphenyl pivalate ............................................................ 44

Scheme 16: Synthesis of 2,4-di-tert-butylphenyl methanesulfonate …..................................... 45

Scheme 17: Synthesis of 2,4-di-tert-butyl-6-iodophenol ............................................................ 47

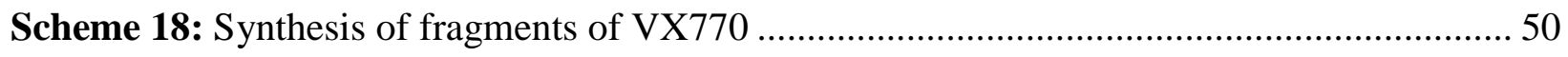

Scheme 19: Synthesis of $N$-(4-butoxyphenyl)-4-oxo-1,4-dihydroquinoline-3-carboxamide ...... 51

Scheme 20: Synthesis of 7-azido-1-(tert-butyl)-6-fluoro-4-oxo-1,4-dihydroquinoline-3carboxylic acid 52 
Scheme 21: Synthesis of azido photoaffinity label, compound 28

Scheme 22: Synthesis of (4-Amino-2-hydroxyphenyl)phenyl)methanone.................................. 54

Scheme 23: Synthesis of benzophenone photoaffinity label, compound 32 ….......................... 55

Scheme 24: Towards the synthesis of trifluoromethyl diazirine starting from $m$-aminophenol.. 55

Scheme 25: Towards the synthesis of trifluoromethyl diazirine starting from $\mathrm{N}$-(3-

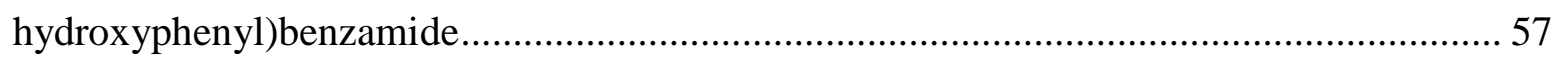

Scheme 26: Synthesis of 6-Bromo-4-oxo-1,4-dihydroquinoline-3-carboxylic acid ..................... 59 


\section{List of Abbreviations:}

ABC ATP-binding cassette

AMPK Adenosine monophosphate-activated protein kinase

Anh. Anhydrous

Aq. Aqueous

ASL Airway surface liquid

ATP Adenosine triphosphate

CF $\quad$ Cystic fibrosis

CFTR Cystic fibrosis transmembrane conductance regulator

Conc. Concentrated

Corr-4a Corrector-4a

DCM Dichloromethane

DEEMM Diethyl-2-(ethoxymethylene)malonate

DIPEA $\quad N, N$-diisopropylethylamine

DMAP 4-Dimethylaminopyridine

DMF $\quad N, N$-dimethylformamide

DMSO Dimethylsulfoxide

DNA Deoxyribonucleic acid

$\mathrm{ENaC} \quad$ Epithelial sodium channel

eq Equivalent(s)

ER Endoplasmic reticulum

EtOAc Ethyl acetate

$\Delta$ F508 Deletion of phenylalanine amino acid at position 508 on the CFTR protein

$\mathrm{FEV}_{1} \quad$ Forced expiratory volume in one second

g $\quad \operatorname{Gram}(\mathrm{s})$ 
G551D Replacement of glycine amino acid by an aspartic acid residue at position 551 on the CFTR protein

HBE Human bronchial epithelia

HBTU O-Benzotriazole- $N, N, N^{\prime}, N^{\prime}$-tetramethyluronium hexafluorophosphate

HPLC High-performance liquid chromatography

$\mathrm{I}_{\mathrm{T}} \quad$ Transepithelial current

LHS Left hand side

Lit Literature

$\mathrm{MeOH} \quad$ Methyl alcohol

$\mathrm{MHz} \quad$ Megahertz

$\min \quad$ Minute(s)

mL Milliliter(s)

mmol Millimole(s)

mp Melting point

mRNA Messenger ribonucleic acid

MSD Membrane spanning domain

NBD Nucleotide-binding domain

NMR Nuclear magnetic resonance

ORCC Outwardly rectifying chloride channel

P。 Open probability

PG01 Phenylglycine-01

PKA Protein kinase A

PKC Protein kinase C

PPA Polyphosphoric acid

RD Regulatory domain 
R117H Replacement of arginine amino acid by a histidine residue at position 117 on the CFTR protein

RHS Right hand side

ROMK Renal outer medullary potassium channel

RT Room temperature

TFA Trifluoroacetic acid

THF Tetrahydrofuran

TLC Thin layer chromatography

TMSCl Trimethylsilyl chloride

$t_{R} \quad$ Retention time

US FDA The food and drug administration

UV Ultra-violet light 


\section{Introduction}

\subsection{Background}

Cystic fibrosis (CF) is one of the most common life-threatening genetic diseases among people of Caucasian origin. It is an autosomal recessive disorder characterized by a widespread dysfunction of exocrine glands particularly in lungs and the gastrointestinal tract leading to severe complications and often early death. ${ }^{1} \mathrm{CF}$ was first recognized in 1938 by the pathologist Dorothy Andersen and since then the interest in understanding the pathophysiology and the underlying mechanism of the disease has been in continuous growth. ${ }^{1}$ In the 1950 's, it was noted by Kessler and Andersen that cystic fibrosis patients show an abnormal electrolyte composition of the sweat (excess $\mathrm{NaCl}){ }^{42}$ Further investigations suggested that the disturbance in fluids and electrolyte transport is associated to an abnormally low chloride ion permeability through epithelial membranes that leads to poor $\mathrm{NaCl}$ reabsorption in sweat ducts and consequently high concentration of $\mathrm{NaCl}$ in the sweat of cystic fibrosis patients. ${ }^{3}$ The underlying cellular defect of this abnormality remained unknown until the identification of the gene mutation responsible for this defect in 1989. ${ }^{1}$ Molecular cloning experiments have allowed the isolation of DNA segments containing the cystic fibrosis gene locus. The CF gene is located on the long arm of chromosome 7, embracing 180000 base pairs. ${ }^{4}$ In 1989 , John Riordan et al. were able to fully characterize the product of the CF gene and it was given the name of CFTR (cystic fibrosis transmembrane conductance regulator) protein. ${ }^{4}$ The CFTR glycoprotein is comprised of 1480 amino acids and is a member of the ATP-binding cassette (ABC) superfamily; it is a family of active transporters that use the energy of ATP hydrolysis to translocate ions across epithelial membranes based on concentration gradient. ${ }^{5,11}$ 


\subsection{Structure and Function of CFTR Protein:}

Uniquely, the CFTR protein acts as a chloride channel not a transporter and it is mainly constituted of two membrane spanning domains (MSD), two nucleotide-binding domains (NBD) and a regulatory domain (RD) (Figure 1$){ }^{4}$ Each of the MSD's consists of six hydrophobic segments that form three traversing loops across the phospholipid bilayer which are followed by hydrophilic NBD's, interacting from head to tail to form nucleotide binding sites at their interface. ${ }^{4,6}$ The regulatory domain is located in the middle of the CFTR polypeptide to link both halves of the protein. ${ }^{6}$ It is a highly charged cytoplasmic domain containing multiple phosphorylation sites for protein kinase A (PKA), protein kinase C (PKC) and AMP-activated protein kinase (AMPK). ${ }^{6}$

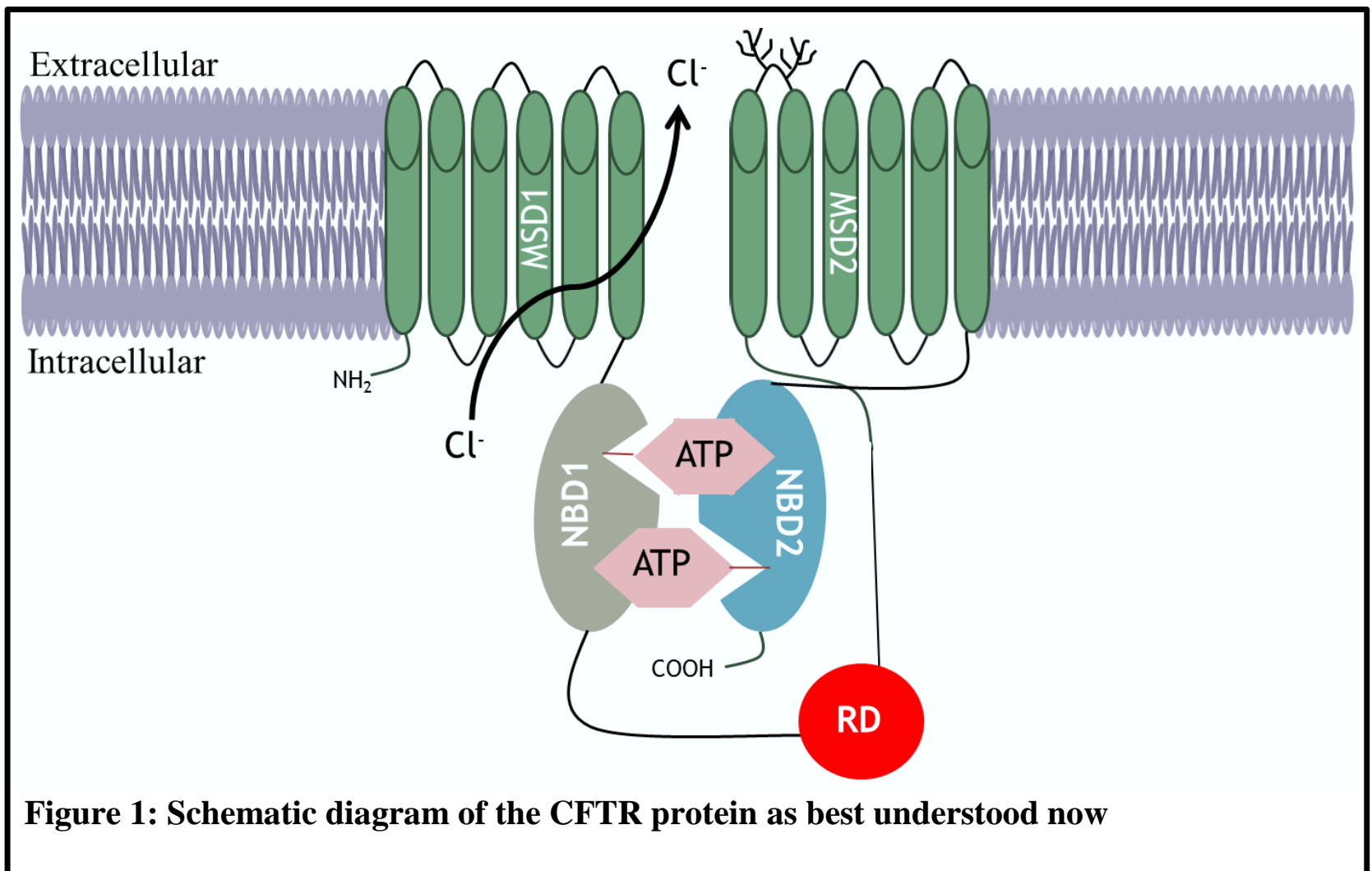

CFTR protein is principally expressed in epithelial membranes such as airways, pancreas, sweat ducts, intestines, etc. It is an anion selective channel that regulates the flow of salt and water 
across epithelial membranes. The activation and opening of the CFTR channel requires two main factors; the phosphorylation of the RD, mainly by PKA, and binding of two ATP molecules at the NBD's. ${ }^{7}$ ATP binding at the interface between NBD1 and NBD2 stimulates the dimerization of the NBD's that leads to channel opening and chloride secretion. Whereas the closure of the channel is induced by the ATPase activity (i.e. the hydrolysis of ATP into ADP and inorganic phosphate), that promotes the dissociation of the NBD heterodimer. ${ }^{8}$ The part of CFTR responsible for the chloride channel function was found to be in $\alpha$ helices 5 and 6 of MSD1. ${ }^{10}$ The series of defects and complications associated with cystic fibrosis cannot only be reconciled with abnormalities or mutations in a chloride channel, which suggests that CFTR is a multifunctional protein.

\subsection{CFTR Acting as A Multifunctional Protein:}

Besides being a chloride channel, CFTR can also act as a conductance regulator for other ion channels. It acts as a selective $\mathrm{HCO}_{3}{ }^{-}$ion channel and a regulator of other channels and transporters directly or indirectly, such as; outwardly rectifying chloride channel (ORCC), epithelial sodium channel $(\mathrm{ENaC})$ and renal outer medullary potassium channel (ROMK) or other inwardly rectifying $\mathrm{K}^{+}$channels (Figure 2). ${ }^{9,10}$ 


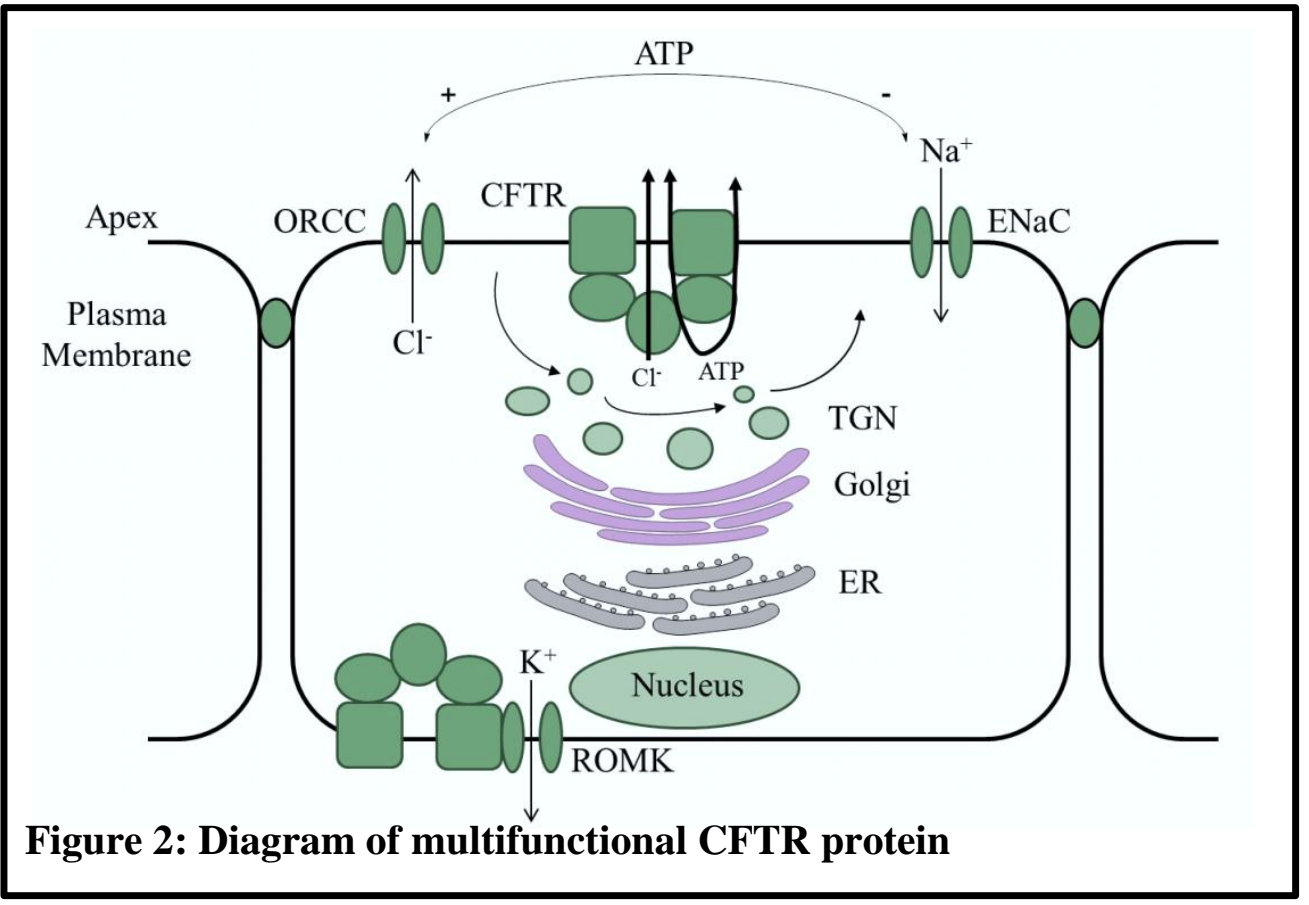

The ORCC is a chloride channel that helps the efflux of chloride ions through cell membranes. The expression of the CFTR is essential for PKA stimulation and the positive regulation of ORCC. ${ }^{10}$ The ATP is a cofactor for PKA or PKC phosphorylation of the ORCC and hence the activation of the channel. A functional CFTR is essential for the transport and the release of ATP out of the cell which in turn will stimulate the phosphorylation of the channel either directly or through purinergic receptors. ${ }^{10}$ The mechanism whereby CFTR promotes the release of ATP is still not fully resolved. Knowing the fact that immnunopurified CFTR is not an ATP channel as it cannot conduct ATP itself, suggests two plausible mechanisms; the presence of separate specific ATP protein channel or CFTR requires additional cofactors and regulatory proteins to conduct ATP. ${ }^{10}$ The CFTR domains essential for the interaction with ORCC have been demonstrated to be NBD1 and the R domain. A dysfunction in the CFTR protein will lead to a consequent inhibition of chloride ion secretion through the ORCC channel.

On the other hand, a functional CFTR is essential for a parallel inhibition and the downregulation of the epithelial $\mathrm{Na}^{+}$channel $(\mathrm{ENaC}) .{ }^{9}$ A malfunctioning CFTR protein will cause a disturbance 
in $\mathrm{Na}^{+}$transport across apical membranes. Cystic fibrosis patients have shown an increased level of $\mathrm{Na}^{+}$absorption that can be attributed to the great activity of the sodium channel. It was observed that the activity of $\mathrm{ENaC}$, in $\mathrm{CF}$ patients, is two to threefold greater than $\mathrm{ENaC}$ derived from the epithelia of non-CF individuals. ${ }^{10}$ The molecular mechanism, whereby CFTR downregulates ENaC, has not been identified yet, but there are a lot of possibilities that are still experimented and illustrated in the literature. ${ }^{10}$ CFTR expression is also important for the activation and the regulation of at least two different isomers of the renal outer medullary potassium channel (ROMK1 and ROMK2). The interaction between CFTR and ROMK has been demonstrated as a direct interaction between nucleotide binding domains of CFTR and ROMK. ${ }^{10}$ Any mutation or dysfunction of the CFTR protein will lead to reduced $\mathrm{Cl}^{-}$secretion and a secondary increase in $\mathrm{Na}^{+}$reabsorption.

\subsection{Normal CFTR Protein Synthesis:}

Since the characterization of the CFTR gene, over 1600 different gene mutations have been identified. $^{2}$ These mutations interfere with the normal pathway of CFTR from the nucleus to the plasma membrane leading to either no $\mathrm{Cl}^{-}$channel or a malfunctioning one. The journey of the CFTR protein includes many cellular proteins within multiple compartments (Figure 3). ${ }^{12}$ It first starts with transcription of the DNA code, within the nucleus, into mRNA. The mRNA leaves the nucleus to be translated, mainly in the endoplasmic reticulum (ER), into a nascent polypeptide. Within the ER lipid bilayer, the nascent protein undergoes further protein maturation and a cotranslational folding process. ${ }^{11}$ Any formed misfolded CFTR protein will be bound to a specific chaperone protein to carry it through an ER-associated degradation process, ubiquitinization, followed by degradation in the ubiquitin proteasome system. The cytoplasmic transfer of the properly folded CFTR protein to Golgi apparatus is done through a variety of 
chaperone proteins, where it will undergo posttranslational modification, notably glycosylation. The CFTR processing involves its conversion from mannose-enriched to a mature oligosaccharide side chain attached at the aspargine residues located in the fourth loop of MSD2. ${ }^{11}$ The mature CFTR will be shuttled, by clathrin-coated vesicles, from the Golgi and stationed in the plasma membrane. Once inserted into the plasma membrane, CFTR turns over at a rate of $10 \%$ per minute and has a half-life of $\sim 12-24$ hrs. Finally, the internalization of the mature protein proceeds through clathrin-coated endosomes. ${ }^{11}$

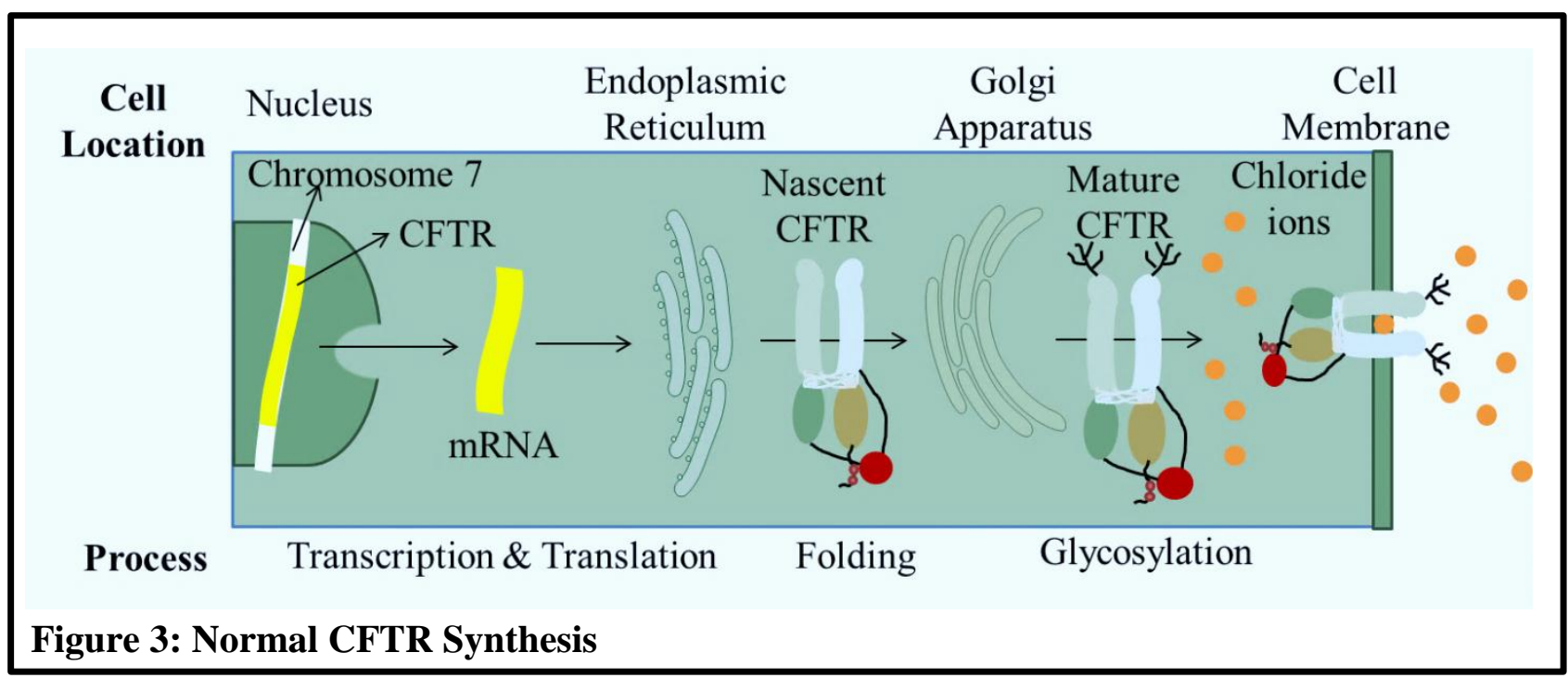

\subsection{CFTR Gene Mutations:}

There are hundreds of different CF mutations, but most of them are rare. ${ }^{11}$ The most common types of CF mutations, affecting $\sim 80 \%$ of patients, can be mainly categorized into five classes according to their functional effect on CFTR production (Table 1). ${ }^{11}$ 


\begin{tabular}{|c|c|c|c|c|c|c|}
\hline Class & $\begin{array}{l}\text { Approximate } \\
\text { Worldwide } \\
\text { Frequency }\end{array}$ & $\begin{array}{c}\text { Predominan } \\
\text { t Mutation } \\
\text { Type }\end{array}$ & $\begin{array}{c}\text { Common } \\
\text { Representative } \\
\text { Mutations }\end{array}$ & $\begin{array}{c}\text { CFTR } \\
\text { Domain } \\
\text { Location }\end{array}$ & $\begin{array}{c}\text { CFTR } \\
\text { Protein } \\
\text { Outcome }\end{array}$ & $\begin{array}{c}\text { Functional } \\
\text { Consequence }\end{array}$ \\
\hline I & $\sim 10 \%$ & $\begin{array}{l}\text { Nonsense, } \\
\text { splice }\end{array}$ & $\begin{array}{c}\text { G524X, } \\
\text { W1282X, } \\
\text { R553X, R1162X }\end{array}$ & $\begin{array}{l}\text { NBD1, } \\
\text { NBD2, } \\
\text { MSD1 }\end{array}$ & No CFTR & $\mathrm{No}^{-} l^{-}$transport \\
\hline II & $70 \%$ & Missense & $\Delta \mathrm{F} 508, \mathrm{~N} 1303 \mathrm{~K}$ & $\begin{array}{l}\text { NBD1, } \\
\text { NBD2 }\end{array}$ & $\begin{array}{l}\text { Defective } \\
\text { processing }\end{array}$ & $\mathrm{No} \mathrm{Cl}^{-}$transport \\
\hline III & $2 \%-3 \%$ & Missense & G551D, R560T & $\begin{array}{l}\text { NBD1, } \\
\text { NBD2 }\end{array}$ & $\begin{array}{l}\text { Defective } \\
\text { regulation }\end{array}$ & $\mathrm{No}^{-} l^{-}$transport \\
\hline IV & Uncertain, $<2 \%$ & Missense & R117H, R347P & $\begin{array}{l}\text { MSD1, } \\
\text { MSD2 }\end{array}$ & $\begin{array}{c}\text { Altered } \\
\text { conductance }\end{array}$ & $\begin{array}{c}\text { Minimal } \\
\text { expression and } \\
\mathrm{Cl}^{-} \text {transport } \\
\end{array}$ \\
\hline $\mathbf{V}$ & Uncertain, $<1 \%$ & $\begin{array}{l}\text { Missense, } \\
\text { splice }\end{array}$ & $\begin{array}{c}3349+10 \mathrm{~Kb} \\
\mathrm{C} \rightarrow \mathrm{G}\end{array}$ & Intron & $\begin{array}{l}\text { Reduced } \\
\text { synthesis }\end{array}$ & $\begin{array}{c}\text { Reduced } \\
\text { expression and } \\
\mathrm{Cl}^{-} \text {transport }\end{array}$ \\
\hline
\end{tabular}

Table 1: The functional classification of CFTR mutations

\subsubsection{Class I Mutations: Defective Protein Production: (Figure 4a)}

Class I includes nonsense mutations where single point alteration in DNA leads to the formation

of premature termination codons (eg, UAA, UGA, UAG) in the protein coding region. ${ }^{11}$ This will lead to premature termination of translation and splice defects. This mutation will result in a truncated, unstable mRNA and consequently the formation of no or an aberrant protein that contains deleted or new sequences of amino acids. This nonfunctional protein will be degraded before reaching the epithelial membrane leading to no $\mathrm{Cl}^{-}$transport. Nonsense mutations affect around $10 \%$ of CF patients worldwide. ${ }^{13}$ 
a) Class I:

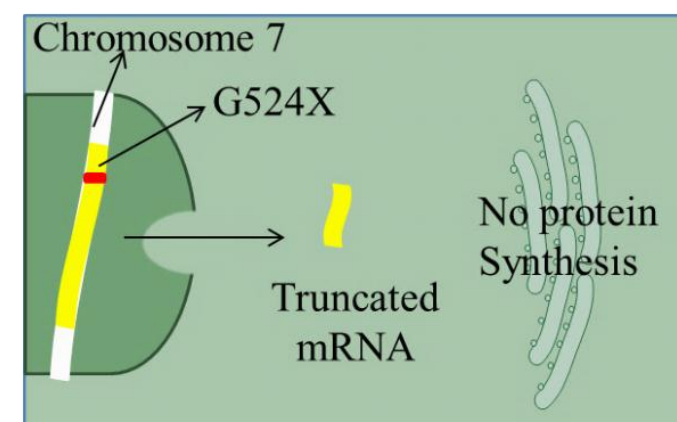

No CFTR at the cell membrane

b) Class II:

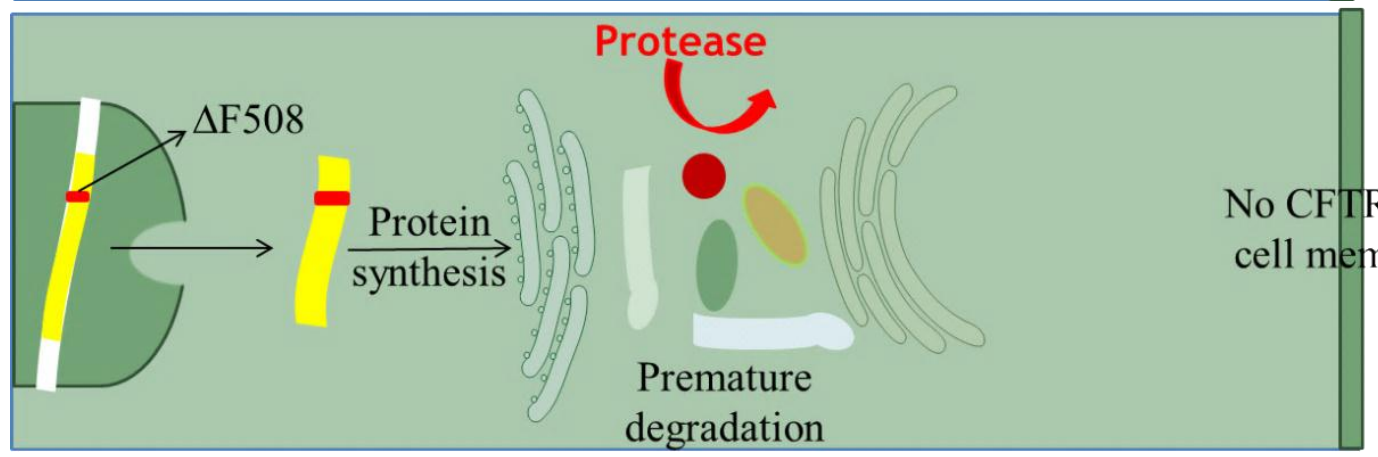

c) Class III:

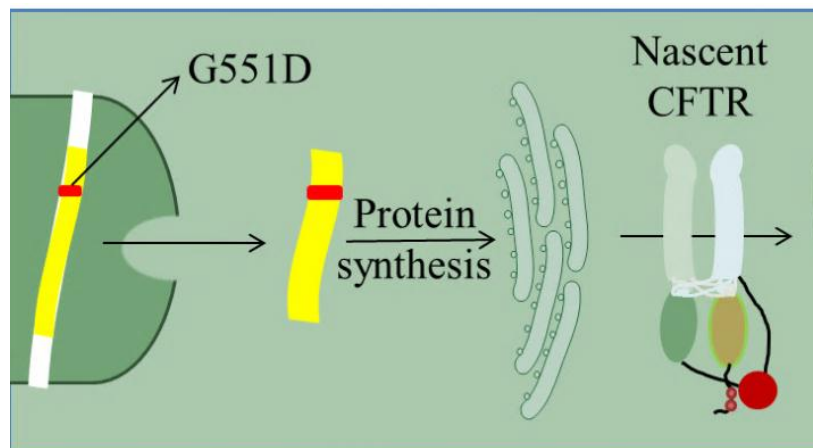

d) Class IV:
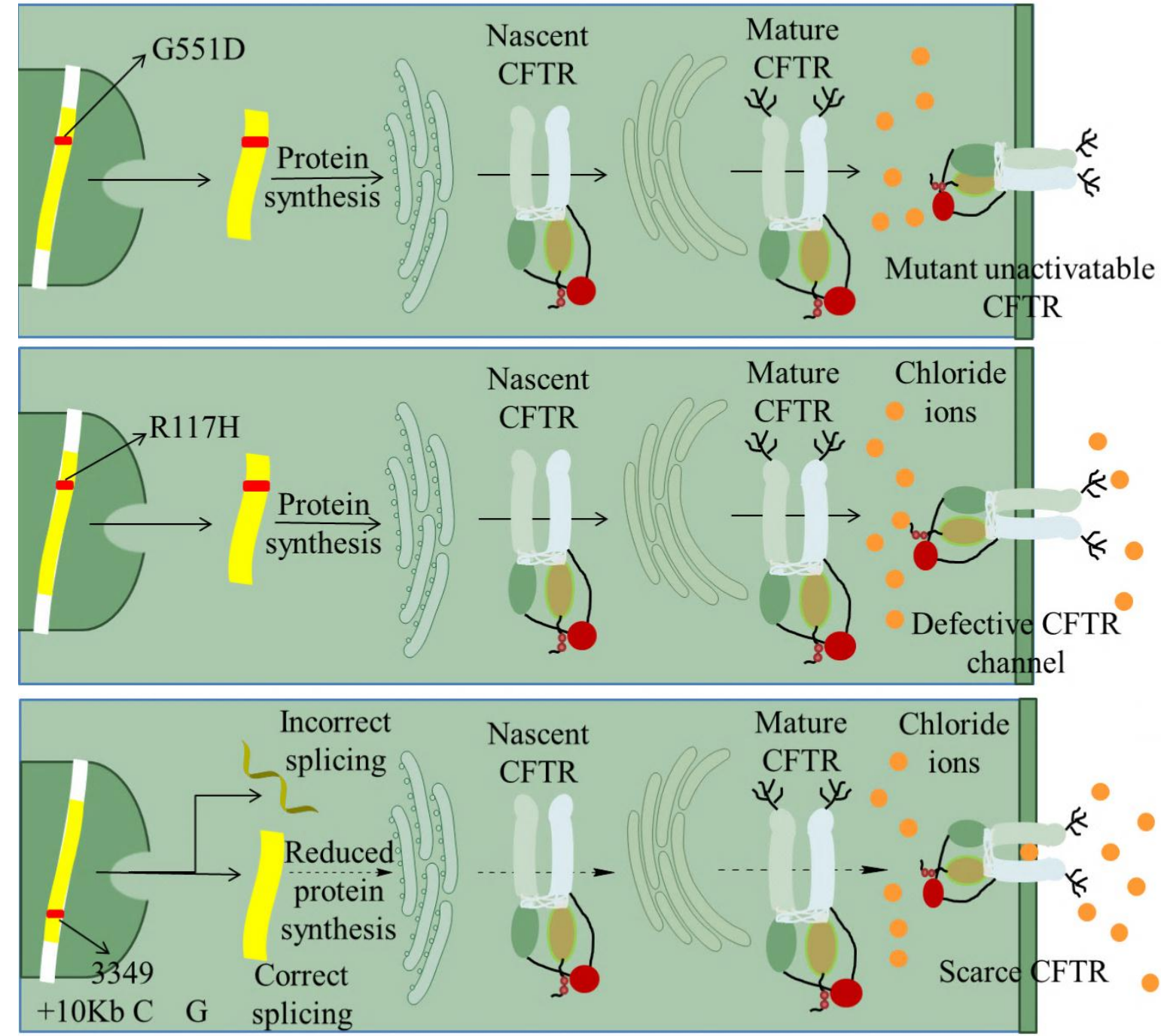

e) Class V:

\section{Figure 4: CF-Related Mutations}




\subsubsection{Class II Mutations: Defective Protein Processing: (Figure 4b)}

Class II of mutations includes the most common type of CFTR mutation, $\Delta \mathrm{F} 508$. The $\Delta \mathrm{F} 508$ is the most frequent and severe mutation that contributes to $\sim 60 \%$ of all CF genes and in $\sim 90 \%$ of $\mathrm{CF}$ patients as at least one allele. ${ }^{23}$ It involves the deletion of phenylalanine amino acid located at position 508 in the NBD1 of the CFTR protein (Figure 5). This kind of mutation causes a mistrafficking problem. This problem arises when the formed misfolded, partially glycosylated protein fails to be recognized by cellular quality control mechanisms. Thus, it will be retained inside the endoplasmic reticulum and subsequently subjected to premature degradation and proteolysis rather than transported to the plasma membrane (defective trafficking). ${ }^{13,14}$ The trafficking of $\Delta \mathrm{F} 508$ mutated CFTR can be rescued in vitro, either under low temperature or overexpression, but it shows extremely impaired channel activity. The maximal open probability of the rescued $\Delta \mathrm{F} 508$ mutant is highly decreased where the amount of time the mutated channel is in the open configuration was three fold lower than that of the wild type CFTR protein leading to lower chloride conductance (defective gating). ${ }^{14}$ 


\section{CFTR Sequence:}

Nucleotide

Amino Acid ATC AT

ATC AT C TT

Ile Ile

506
T GGT GTT

Gly

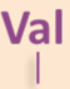

510

\section{Deleted in $\Delta \mathrm{F} 508$}

\section{$\triangle$ F508 CFTR Sequence:}

Nucleotide

Amino Acid
ATC ATT GGT GTT

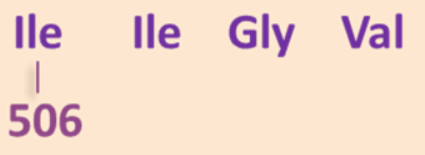

Figure 5: $\Delta$ F508 mutation; phenylalanine amino acid is deleted

\subsubsection{Class III Mutations: Defective Regulation: (Figure 4c)}

Glycine to aspartic acid missense mutation (G551D) is the third most common type of CFTR mutation occurring in $~ 5 \%$ of CF patients worldwide. ${ }^{15}$ It takes place when the glycine amino acid, located at position 551within the NBD1 of the CFTR protein, is replaced by an aspartic acid (Figure 6). It interferes with NBD1 and NBD2 heterodimerization, ATP binding and hydrolysis. ${ }^{16}$ In this kind of mutation, the mutated CFTR protein is fully glycosylated, adequately folded and inserted appropriately into the plasma membrane, but it exhibits defective gating. ${ }^{16}$ The G551D-CFTR mutant has low open probability, tenfold lower than the wild type, and consequently defective epithelial $\mathrm{Cl}^{-}$permeability (defective gating). 


\section{CFTR Sequence:}

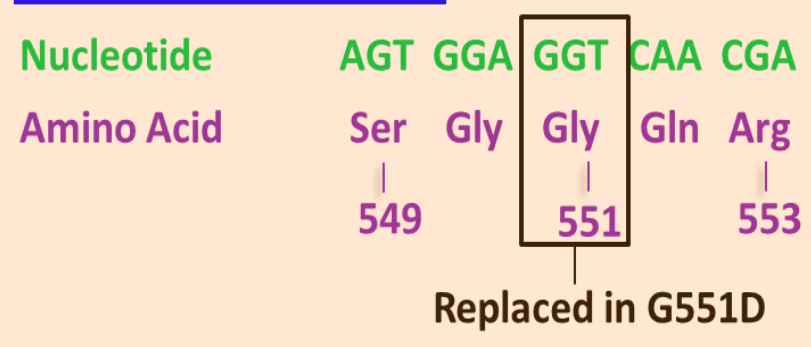

\section{G551D CFTR Sequence:}

Nucleotide

Amino Acid
AGT GGA

Ser Gly

549

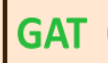

Asp

551
CAA CGA

GIn Arg

553

Figure 6: G551D mutation; glycine amino acid is replaced by aspartic acid

\subsubsection{Class IV Mutations: Defective Conduction: (Figure 4d)}

The defective conduction class of mutation usually affects a membrane spanning domain of CFTR which contributes to the channel pore. ${ }^{13} \mathrm{R} 117 \mathrm{H}$ is the most common type of mutation among this class; it has a worldwide frequency of $0.5 \% .{ }^{11} \mathrm{R} 117 \mathrm{H}$ is a missense mutation where arginine amino acid, at position 117 within MSD1 in CFTR protein, is substituted by a histidine residue. ${ }^{11}$ In this kind of mutation, CFTR is normally inserted into the plasma membrane, the $\mathrm{R}$ domain is phosphorylated and the NBD binds ATP, but the channel open probability is reduced to one third that of the wild type leading to a defective ion channel. ${ }^{13}$ The reduced open channel time leads to decreased chloride ion permeation and defective single-channel chloride ion conductance. ${ }^{11}$ 


\subsubsection{Class V Mutations: Reduced Synthesis: (Figure 4e)}

Reduced synthesis mutation is only found in $<1 \%$ of CF patients. ${ }^{11}$ It involves transcriptional dysregulation and defective splicing machinery, which results in the formation of a mixture of both correctly and aberrantly spliced mRNA. ${ }^{11}$ This will lead to reduced abundance of functional CFTR protein on the plasma membrane and thus reduced chloride conductance across the membrane.

\subsection{Symptoms of Cystic Fibrosis:}

The lack of functioning CFTR at the proper location in the epithelial membrane, due to different types of mutations, leads to malfunctioning CFTR-dependent ion channels. This results in the disruption of ion transport homeostasis through epithelial membranes in different organs. ${ }^{1}$ In the lungs, CFTR and ENaC are important for the regulation of the water volume and height of the airway surface liquid (ASL). ${ }^{17}$ ASL is the layer covering the lung surface. It is composed of mucus and periciliary liquid and it is necessary for mucociliary clearance. ${ }^{1}$ In $\mathrm{CF}$, overexpression of $\mathrm{ENaC}$ leads to increased absorption of salt and water from airway surfaces and ASL depletion. ${ }^{17}$ Dehydration of airway surface liquid leads to defective mucociliary clearance and reduced bacterial clearance. Mucus accumulation provides a good environment for bacterial colonization and subsequently chronic airway diseases, chronic inflammation and respiratory failure. Pulmonary disease is the primary cause of morbidity in cystic fibrosis $(>90 \%){ }^{1,18}$ Thick mucus can also accumulate in the pancreas and intestines, leading to the obstruction of pancreatic ducts and preventing the passage of digestive enzymes to small intestines. This leads to pancreatic insufficiency, maldigestion, poor growth and weight loss. Other symptoms of cystic fibrosis are liver cirrhosis, rectal prolapse, male infertility, diabetes, and a salty sweat. 


\subsection{Towards The Treatment of CF:}

Isolation of CFTR protein and understanding of molecular mechanisms behind the clinical manifestations of the disease has helped in the development of new treatments to overcome the symptoms of cystic fibrosis. Current therapies alleviate the symptoms; improving the quality of life of $\mathrm{CF}$ patients by treating downstream disease processes that are secondary to CFTR malfunction, without curing the disease itself. ${ }^{19}$ This includes inhaled antibiotics and antiinflammatory agents that help to eradicate bacterial infections. CF patients are also given pancreatic enzymes to help digestion, supplementary vitamins to ensure good nutrition and mucolytic agents to break down mucus and clear up airways and pancreatic ducts. At present, other drug approaches are being developed that can overcome the underlying genetic defect causing the disease and help to stop or reduce the progression of the disease. Development of a CF gene therapy by insertion of a corrective DNA sequence is still under progress with no positive results. ${ }^{20}$

\subsubsection{Small Molecule Therapy:}

The discovery of small molecules, drug candidates, which can interact with the malfunctioning CFTR protein, has evolved over the years. This therapy has the advantage over gene therapy, as it avoids the potential treatment of wrong cells and/or losing the physiological CFTR regulation. ${ }^{23}$ Small molecule therapy mainly involves the development of new compounds that can overcome the underlying CFTR defects and help in the restoration of its function. These defects can be mainly summarized into 2 points:

1) Aberrant CFTR folding and premature degradation,

2) Defective channel gating. 
Development of such pharmacological agents is usually done through high throughput screening. High throughput screening involves testing a large collection of small molecules, either natural or synthetic drug-like compounds, using an automated assay designed to recognize active compounds with high efficiency and reliability. ${ }^{24}$ The active candidates in the initial primary screen are further evaluated and the lead compounds are then optimized and intensively screened as potential new drugs. ${ }^{24}$ Small molecules developed for cystic fibrosis treatment are classified as either correctors or potentiators (Figure 7). Correctors are pharmacological agents that overcome the defective processing of mutant CFTR. They can interact with either chaperone proteins to block CFTR premature degradation, or with the CFTR protein itself to help its proper folding and trafficking to the cell membrane, thus rescuing the cell surface expression of the mutant CFTR. ${ }^{26}$ Potentiators are small molecules that can repair the gating defect of CFTR ion channel by interacting with mutant CFTR protein, localized at the cell surface. They potentiate the channel activity of mutant CFTR and increase $\mathrm{Cl}^{-}$transport across the membrane. ${ }^{7}$

Treatment of $\Delta \mathrm{F} 508$ is presumed to require a combination of both correctors and potentiators to efficiently address all the functional defects (trafficking and gating), and help to rescue the CFTR protein to the plasma membrane and restore its function. Treatment of G551D can be monotherapeutic using only potentiators as it is a less complex mutation.

Several classes of efficacious correctors and potentiators have been developed in different laboratories. They can rescue the CFTR protein with different mechanisms. Examples of each class are elucidated in Figure 7. ${ }^{15,26}$ 
a) Correctors:<smiles>COc1cc(/C=C/C(=O)/C=C(O)/C=C/c2ccc(O)c(OC)c2)ccc1O</smiles>

(Curcumin)<smiles>CCCc1nn(C)c2c(=O)[nH]c(-c3cc(S(=O)(=O)N4CCN(C)CC4)ccc3OCC)nc12</smiles>

(Sildenafil)

b) Potentiators:<smiles>O=c1cc(-c2ccc(O)cc2)oc2cc(O)cc(O)c12</smiles>

(Apigenin)

Flavones<smiles>C=CCNC(=O)c1c[nH]c2ccc(S(=O)(=O)N(C)c3ccccc3OCC)cc2c1=O</smiles>

(SF-01)

Sulfonamides<smiles>COc1ccc(Cl)cc1Nc1nc(-c2sc(NC(=O)c3ccccc3)nc2C)cs1</smiles>

(Corr-4a)

Bithiazoles<smiles>Cc1ccc(NC(=O)C2(c3ccc4c(c3)OC(F)(F)O4)CC2)nc1-c1cccc(C(=O)O)c1</smiles>

(VX-809)<smiles>CC(C)c1ccc(NC(=O)C(c2ccccc2)N(C)C(=O)Cc2c[nH]c3ccccc23)cc1</smiles>

(PG-01)

Phenylglycines<smiles>O=c1[nH]c2cc(C(F)(F)F)ccc2n1-c1cc(Cl)ccc1O</smiles>

(NS004)

Benzimidazolones

Figure 7: Correctors and Potentiators 
Development of one hybrid molecule that possess both corrector and potentiator ability has also interested different research groups. Such a molecule would be very beneficial especially for CF patients carrying $\Delta \mathrm{F} 508$ mutation. The development of a hybrid compound has the advantage over $\mathrm{CF}$ therapies requiring separate administration of correctors and potentiators, and also it requires lower cost to develop a single drug therapy. ${ }^{27}$ The Kurth group has designed a hybrid molecule that contains Corr-4a, corrector, and PG-01, potentiator, linked by a diethylene glycol spacer through an ester bond (Figure 8). ${ }^{25}$ Upon enzymatic hydrolysis, corrector and potentiator will be delivered. The potency of the molecule has been tested and it proved to have some activity in the restoration of cellular processing and channel activity. ${ }^{25}$

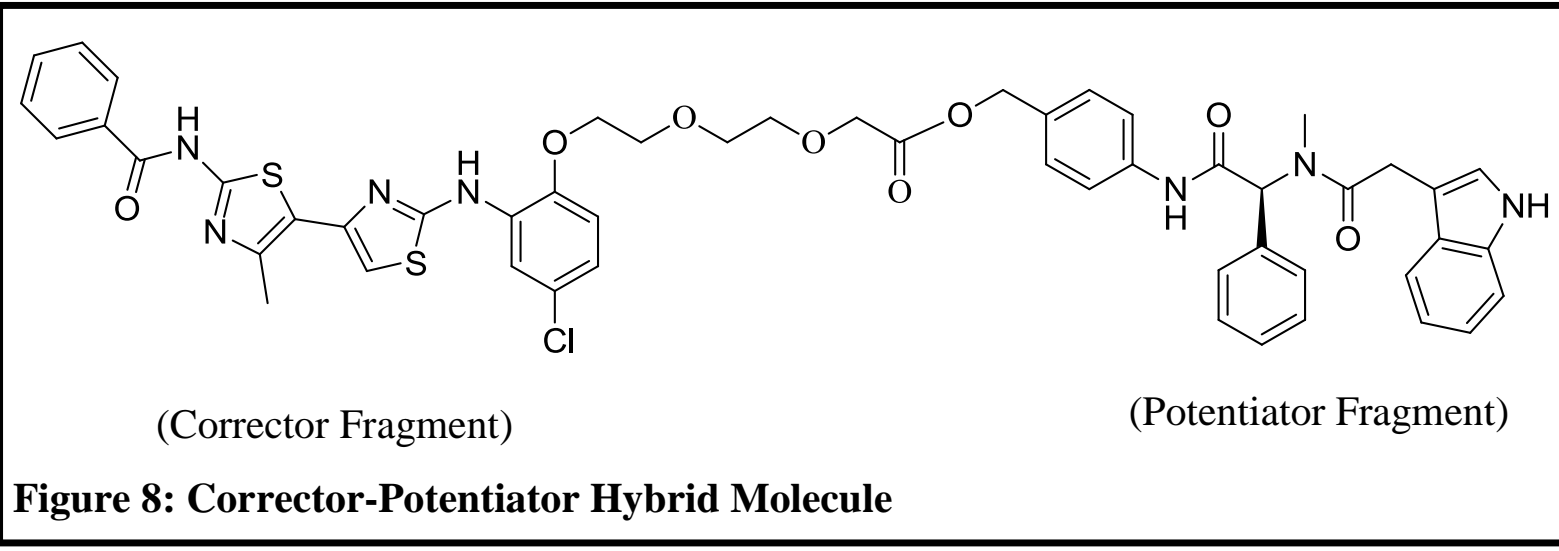

Another example of a dual acting molecule is a type of cyanoquinoline developed by the same research group. ${ }^{27}$ It consists of a cyanoquinoline core and arylamide moiety linked by a flexible tether (Figure 9). ${ }^{27}$ The use of different arylamide moieties can tune the corrector/potentiator activity of the molecule. The most likely hypothesis of mechanism of action is that the molecule can adopt binding to the two different forms of the binding site, on $\Delta \mathrm{F} 508$ mutant CFTR, that change shape during its transport from ER to the cell membrane. ${ }^{27}$ 


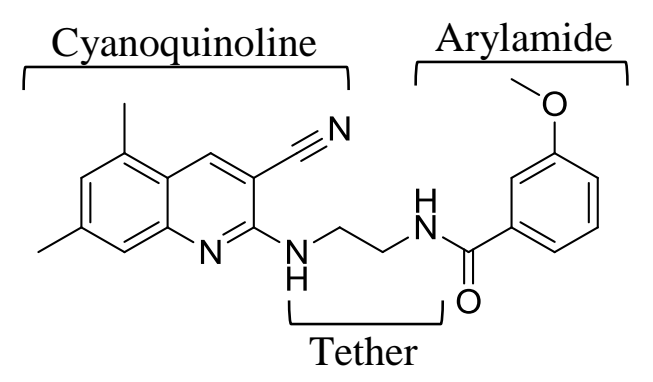

Figure 9: Structure of cyanoquinoline dual acting molecule (corrector/potentiator)

\subsection{2. $\underline{\text { VX770: }}$}

In the late 1990's, Vertex Pharmaceuticals supported by the cystic fibrosis foundation started the development of small molecules, through high throughput screening, that can act as protein (CFTR) modifiers. ${ }^{20}$ Over the years, Vertex Pharmaceuticals has dedicated a great effort in screening a lot of pharmacological compounds, $\sim 230,000$ compounds, by cell assays. ${ }^{20} \mathrm{After}$ more than 15 years of research, the development of the first CF drug has come to fruition and it was given the name of VX770 (Figure 10). In February 2012, VX770 was approved by the U.S. Food and Drug Administration after an unusually fast 3 months review. VX770's generic name is Ivacaftor and it was approved under the name of Kalydeco ${ }^{\mathrm{TM}} .{ }^{20}$<smiles>CC(C)(C)c1cc(C(C)(C)C)c(NC(=O)c2c[nH]c3ccccc3c2=O)cc1O</smiles>

Figure 10: Structure of VX770 
VX770 is a potent, orally bioavailable potentiator. It addresses CF patients carrying G551D mutation ( $\sim 5 \%$ CF patients) as it has the ability to augment the chloride transport activity of the mutated CFTR protein located at the cell membrane. Being a personalized medicine, addressing only a small number of patients, Ivacaftor is an extremely expensive drug that will be taken for a lifetime. It will cost $\$ 294,000$ a year for a twice daily pill. ${ }^{20}$ Although the price of Ivacaftor is still comparable with other drugs for rare diseases, Vertex Pharmaceuticals is planning to make it available for free for uninsured patients with low incomes and to cover up to $30 \%$ of copayments for some with insurance. ${ }^{20}$

Discovery of VX770 was performed via high throughput screening using voltage-sensitive assays. $^{21}$ These assays are based on the change in fluorescence energy transfer between a membrane soluble voltage-sensitive dye and a plasma membrane-localized fluorescent, coumarin-linked phospholipid to monitor the changes in anion flux through CFTR channel. ${ }^{21}$ In vitro pharmacology of VX770, on cultured human bronchial epithelia (HBE) isolated from the bronchi of CF donor lungs carrying G551D and/or $\Delta \mathrm{F} 508$ mutations, ${ }^{19}$ has shown that it has the ability to increase the open probability $\left(\mathrm{P}_{\circ}\right)$ of the CFTR channel (Figure 11), after its activation by PKA, thus improving transepithelial current $\left(\mathrm{I}_{\mathrm{T}}\right)$ in HBE. VX770 can also reduce the excessive sodium and fluid absorption mediated by ENaC resulting in the restoration of ASL, rehydration of apical membranes and improved ciliary beat frequency. ${ }^{19}$ 


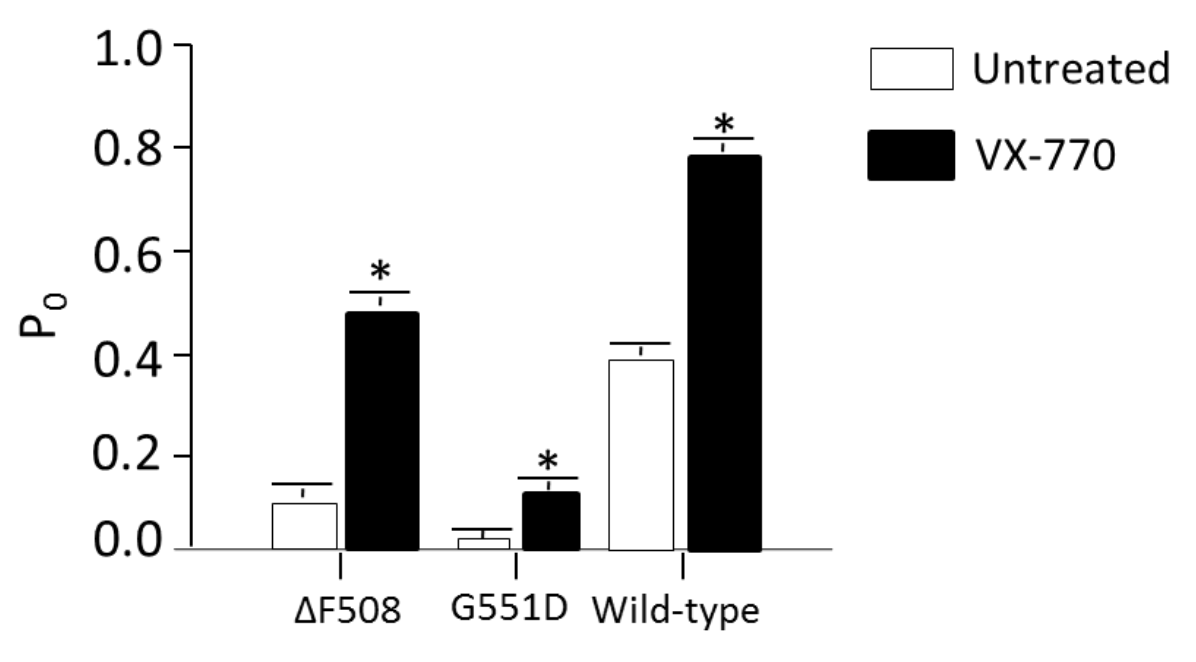

Figure 11: VX770 potentiating gating activity of CFTR. Mean $P$ in presence of PKA and ATP alone (open bars) and with VX770 (filled bars). ${ }^{19}$

In phase II clinical trials, VX770 was orally administered to CF patients carrying the G551D mutation. The main objective of this phase is to evaluate the safety and adverse effects of the drug. The impact of VX770 on the mutant CFTR protein was studied using biomarkers of the CFTR function; e.g. sweat chloride, and the improvement of the lung function determined by measurements of the forced expiratory volume in one second $\left(\mathrm{FEV}_{1}\right)$; which is a standard test that measures the amount of air that can be exhaled in one second. ${ }^{28}$ The results of this phase were positive, as the majority of adverse events of VX770 were mild to moderate in severity. ${ }^{28}$ VX770 has proved to increase CFTR activity as shown by a decrease in sweat chloride levels of CF patients to within the range of healthy individuals. Patients have also experienced good improvement in lung function which was assessed by the increase in $\mathrm{FEV}_{1}$ after administration of VX770. ${ }^{28}$ To further evaluate the drug, phase III clinical trials were then conducted on VX770 and the results were released by Vertex Pharmaceuticals in February 2012. A randomized, double-blind, placebo controlled protocol was tried in subjects of 12 years or older (mean age $=$ 25.5) carrying at least one allele of G551D-CFTR mutation. ${ }^{22}$ Subjects were randomly given 150 
mg of VX770 every 12 hrs or placebo for 48 weeks. ${ }^{22}$ The primary efficacy end point was the absolute change from the baseline through week 24 in the percent of predicted $\mathrm{FEV}_{1}{ }^{22}$ Secondary end points included measures such as; the change from baseline through week 48 in the percent of predicted $\mathrm{FEV}_{1}$, the change in body weight from baseline to weeks 24 and 48 and the change from the baseline in the concentration of sweat chloride (Table 2 ). ${ }^{22}$ Safety was also evaluated throughout this study. At week 24, the change from baseline in the percent of predicted $\mathrm{FEV}_{1}$ was $10.6 \%$ higher in the VX770 group than in the placebo group. ${ }^{22}$ At week 48 , the treatment effect was maintained with a change in the percent of predicted $\mathrm{FEV}_{1}$ from the baseline of $10.5 \%$ greater in VX770 group than the placebo one. ${ }^{22}$ By the end of the study, subjects in VX770 group gained $3.1 \mathrm{~kg}$

while the placebo group had gained $0.4 \mathrm{~kg} .{ }^{22}$ At week 24 , a large correction in the elevated sweat chloride level was observed, with the change from baseline in sweat chloride being -48.7 $\mathrm{mmol} / \mathrm{L}$ in VX770 group, as compared to $-0.8 \mathrm{mmol} / \mathrm{L}$ in the placebo group. The treatment effect was seen at day 15 and maintained through the end of the study. ${ }^{22}$ Subgroup analyses were also conducted to study the effect of age, sex or severity of lung disease on the clinical response. ${ }^{22}$ The analyses showed consistent responses across subgroups. ${ }^{22}$ VX770 showed a good safety profile with minor adverse events like; headache, nasal congestion, upper respiratory tract infection, rash and dizziness. ${ }^{22}$ 


\begin{tabular}{|c|c|c|}
\hline $\begin{array}{c}\text { Baseline change in } \\
\text { secondary end point }\end{array}$ & \multicolumn{2}{|c|}{ Treatment effect compared to placebo } \\
\hline & Week 24 & Week 48 \\
\hline FEV $_{\mathbf{1}}$ & $10.6 \%$ & $10.5 \%$ \\
\hline Weight & $2.5 \mathrm{~kg}$ & $2.7 \mathrm{~kg}$ \\
\hline Sweat chloride level & $-47.9 \mathrm{mmol} / \mathrm{L}$ & $-45 \mathrm{mmol} / \mathrm{L}$ \\
\hline
\end{tabular}

Table 2: Treatment effect of VX770 as compared to placebo

With these encouraging results, VX770 was approved by the US FDA to be the first approved potent orally bioavailable potentiator. The combination of VX770 with other potent correctors, e.g. VX809, has been also investigated. This combination is now in phase II of clinical trials showing very promising results, which gives hope for a higher population of $\mathrm{CF}$ patients, i.e. patients carrying the $\Delta \mathrm{F} 508$ mutation.

\subsubsection{Labeled Derivatives:}

The exact mechanism of action of VX770 is still unclear. For further investigation towards this issue, making labeled derivatives of the drug will help exploring this area of research and to accurately define the nature of interaction between the drug and the CFTR protein. Radio, fluorescent and photoaffinity labels are good examples for labeled probes that can be tracked in biochemical assays to help reveal the exact site of interaction of the drug with the protein. Photoaffinity labels usually consist of 2 main components; a compound carrying all binding sites of the drug, and a photoactivatable group for crosslinking (Figure 12). 


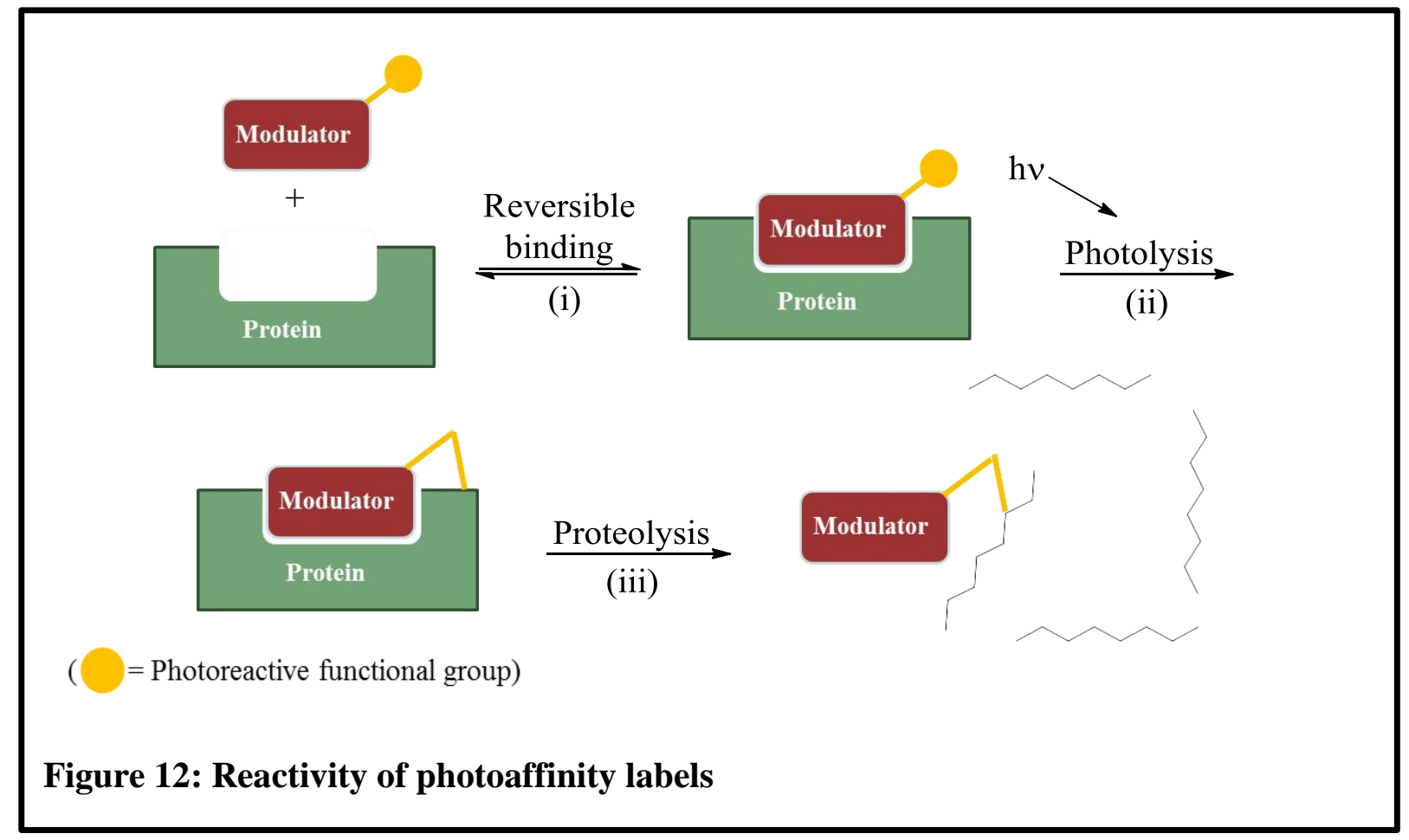

Aryl azides, diazirines, and benzophenones are c201ommon successful photoaffinity labeling reagents (Figure 13). Upon irradiation with ultra-violet (UV) light, a highly reactive intermediate will be formed that has the ability to form a covalent bond and bind irreversibly with the protein. Most of the existing aryl azides compounds tend to function by the same general reaction mechanism but differ in stability, efficiency and absorbance. ${ }^{29}$ By exposing an aryl azide to UV light, a molecule of $\mathrm{N}_{2}$ is extruded leaving a highly reactive nitrene group. The formed nitrene group can be inserted into a $\mathrm{C}-\mathrm{H}$ or $\mathrm{N}-\mathrm{H}$ bond or undergo a ring expansion reaction to react as an electrophile with primary amines (Figure 13a). ${ }^{29}$ The reactive intermediate of diazirenes are carbene intermediates that can form covalent bonds with a nearby protein through an addition reaction with the release of $\mathrm{N}_{2}$ as a byproduct (Figure 13b). ${ }^{29}$ Benzophenones are well known photoreactive cross linking reagents that upon illumination with UV light, a highly reactive ketyl radical is formed that can interact irreversibly with the protein (Figure 13c). ${ }^{30}$ Benzophenones 
are more advantageous than aryl azides and diazirines due to their stability and the ability to be manipulated at ambient light. ${ }^{30}$ These advantages outweigh the bulkiness and hydrophobicity of the benzophenone group. ${ }^{30}$ A radiolabel tag, such as tritium, can be also added to a photoaffinity label to make it easier to trace and identify the product of interaction.

a)<smiles>[N-]=[N+]=Nc1ccc(I)cc1</smiles><smiles>Cc1ccc([N+])cc1</smiles>

(Nitrene)

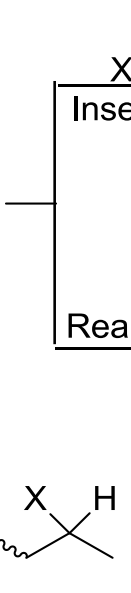

b)

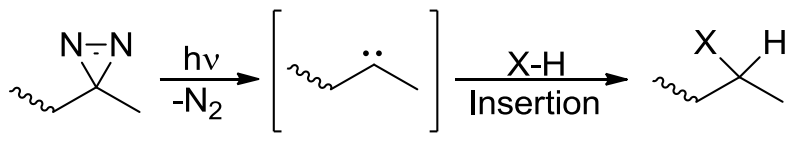

$$
\text { (Carbene) }
$$

c)

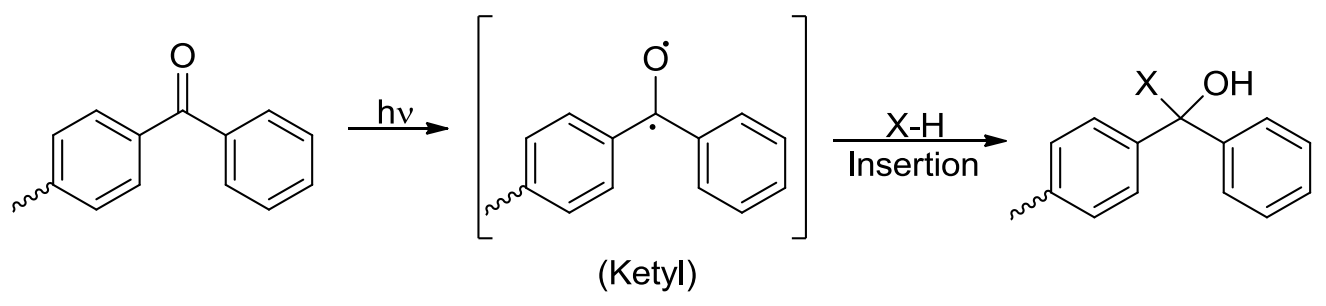

(X-H or $\mathrm{NuH}$ are parts of the target protein molecule)

Figure 13: Reactive intermediates of; a) aryl azides, b) diazirines, and c) benzophenones

\subsubsection{Synthesis of VX770:}

The total synthesis of VX770 has been patented by Vertex pharmaceuticals (Scheme 1). The retrosynthesis strategy includes the formation of both the quinolinone part and the amino phenol part, followed by a straightforward condensation reaction to get the VX770 drug molecule as a final product.

According to the patent, the quinolinone part was synthesized by heating a mixture of aniline and diethyl-2-(ethoxymethylene)malonate at high temperatures to afford diethyl-2- 
((phenylamino)methylene)malonate. ${ }^{45}$ This step was followed by an intramolecular FriedelCrafts-type acylation reaction (also known as the Gould-Jacobs reaction) using a mixture of strong acids, polyphosporic acid and phosphoryl chloride, and heat to get the cyclized quinolinone compound. At the end, an ester hydrolysis was performed yielding the left hand side (LHS) of VX770.

On the other hand, the aminophenol part was made through the reaction of di-t-butylphenol with methyl chloroformate, yielding the methyl carbonate. The formed di-t-butylphenol methyl carbonate was treated with a mixture of nitric and sulfuric acid to afford a mixture of ortho and meta nitro isomers. The next step was isolation and reduction of the meta isomer and ester hydrolysis to give the right hand side (RHS).

A final condensation reaction between LHS and RHS was done to make VX770 molecule.

The patent method has several drawbacks; such as the use of high temperatures and highly strong acidic medium for the Gould-Jacobs cyclization reaction. Another downside of this method is the formation of a mixture of ortho and meta isomers upon nitration. The undesired isomer, ortho, was the major product with a ratio of $2.5: 1$ (ortho:meta) resulting in low yields of the desired product. 
a) Synthesis of the quinolinone (LHS)<smiles>CCOC=C(C(=O)OCC)C(=O)OCC</smiles>

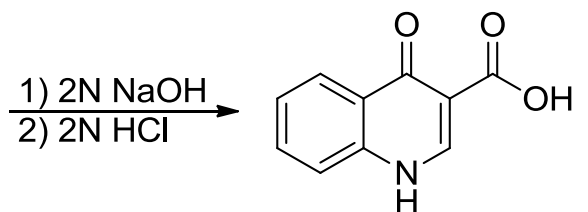

(1)

(4)

(5)

b) Synthesis of the aminophenol (RHS)

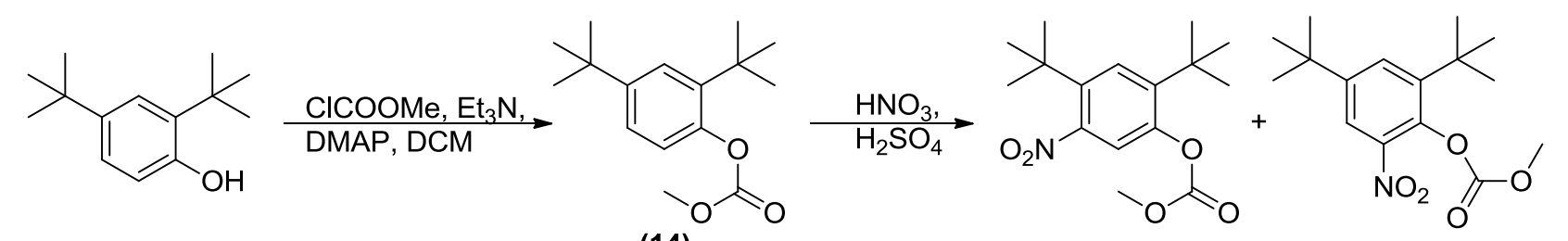
(14)<smiles>CC(C)(C)c1cc([N+](=O)[O-])c(O)c(C(C)(C)C)c1</smiles>

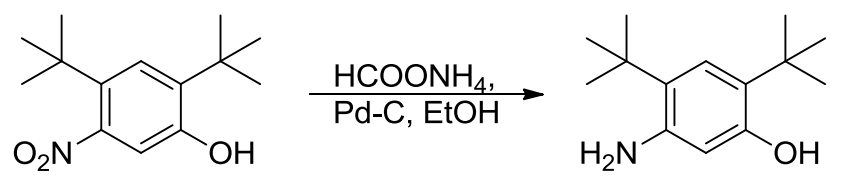

c) Condensation reaction to yield VX770<smiles>C[C@H](Br)NCCN(C)C(C)(C)C</smiles>

Scheme 1: VX770 Total Synthesis 


\subsection{Research Objectives:}

The main goal of this research project is making labeled derivatives of VX770 to be used as probes in biochemical assays to help in the clarification of the exact mechanism of action of the drug. The synthesis of Radio and photoaffinity labeled derivatives will be helpful in tracking the drug molecule and revealing the exact site of interaction between VX770 and the CFTR protein. In this issue, synthesis of the drug under mild and convenient conditions is a key and also it will be very beneficial for large scale production. The synthesis of VX770 fragments is another objective in our research as they will provide information about the best positions for derivatization on the drug molecule. 


\section{Results and Discussion}

\subsection{Towards the Synthesis of 4-Oxo-1,4-dihydroquinoline-3-carboxylic acid (LHS):}

The synthesis of the LHS under mild conditions of low temperature and less harsh acidic conditions was one of the main goals of this research project. In this context, different approaches have been attempted.

\subsubsection{First Approach: Starting from phenylamino malonate:}

The patent procedure of making compound 1, diethyl-2-((phenylamino)methylene)malonate, under high temperature, by heating both aniline and DEEMM neat at $140-150{ }^{\circ} \mathrm{C}$ (Scheme 1a), was modified by using ethanol as a solvent and heating to reflux overnight $\left(78{ }^{\circ} \mathrm{C}\right)$ followed by simply evaporating the solvent to afford compound $\mathbf{1}$ pure in a quantitative yield (Scheme 2).

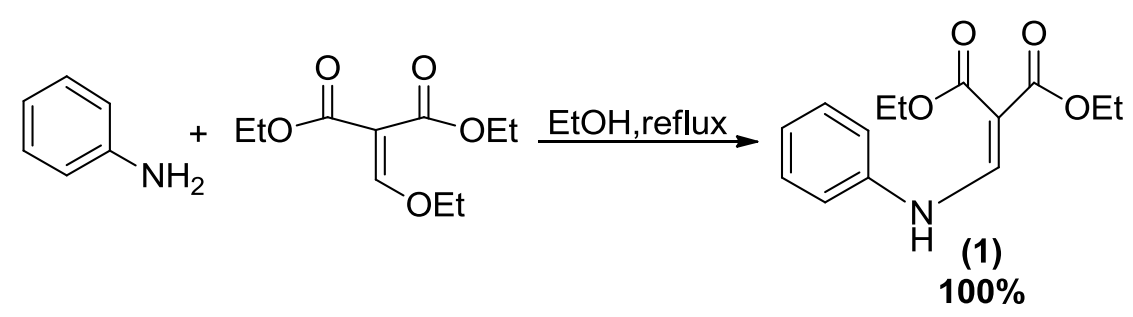

Scheme 2: Synthesis of phenylamino malonate

With compound $\mathbf{1}$ in hand, an intramolecular Friedel-Crafts type acylation reaction was needed to afford the quinolinone LHS ester (Scheme 3). While the patented procedure called for heating in a mixture of polyphosphoric acid and phosphoryl chloride, we sought to find milder conditions. To this end, several different conditions were attempted, summarized in Table 3. 


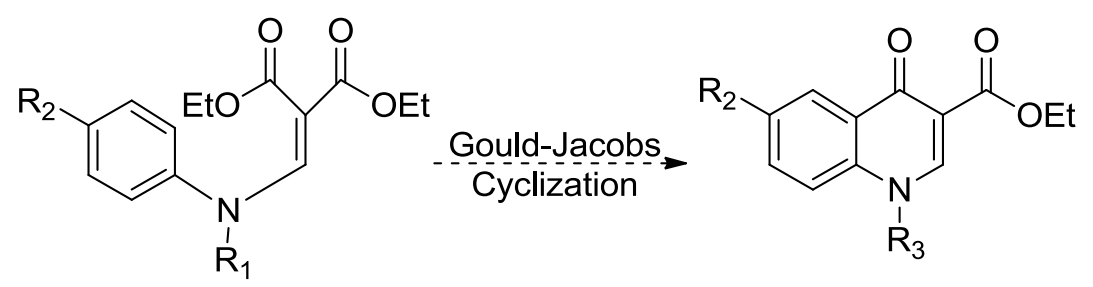

(1)

Scheme 3: Gould-Jacobs cyclization reaction

\begin{tabular}{|c|c|c|c|c|c|c|}
\hline Entry & $\overline{\mathbf{R}_{1}}$ & $\overline{\mathbf{R}_{2}}$ & Catalyst & $\mathbf{R}_{3}$ & Solvent & Temperature \\
\hline 1 & $\mathrm{H}$ & $\mathrm{H}$ & 1 eq. Ti(OEt $)_{4}$ & $\mathrm{H}$ & Anh. EtOH & $78^{\circ} \mathrm{C}$ \\
\hline 2 & $\mathrm{H}$ & $\mathrm{H}$ & 2 eq. $\mathrm{AlCl}_{3}$ & $\mathrm{H}$ & Anh. THF & $66^{\circ} \mathrm{C}$ \\
\hline 3 & $\mathrm{H}$ & $\mathrm{H}$ & 1 eq. $\mathrm{BF}_{3}$ & $\mathrm{H}$ & Anh. THF & $66^{\circ} \mathrm{C}$ \\
\hline 4 & $\mathrm{H}$ & $\mathrm{H}$ & 1 eq. $\mathrm{MgCl}_{2}$ & $\mathrm{H}$ & Anh. THF & $66^{\circ} \mathrm{C}$ \\
\hline 5 & $\mathrm{H}$ & $\mathrm{H}$ & 1 eq. $\mathrm{FeCl}_{3}$ & $\mathrm{H}$ & Anh. THF & RT \\
\hline 6 & $\mathrm{H}$ & $\mathrm{H}$ & 1 eq. $\mathrm{InCl}_{3}$ & $\mathrm{H}$ & Anh. THF & RT \\
\hline 7 & $\mathrm{H}$ & $\overline{\mathrm{H}}$ & 1 eq. $\mathrm{BCl}_{3}$ & $\mathrm{H}$ & $\overline{\mathrm{DCM}}$ & $\overline{\mathrm{RT}}$ \\
\hline $8^{a}$ & $\mathrm{H}$ & $\mathrm{H}$ & $\begin{array}{c}\mathrm{Ac}_{2} \mathrm{O} / \\
1 \text { eq. } \mathrm{AlCl}_{3}\end{array}$ & $-\mathrm{COCH}_{3}$ & - & RT \\
\hline $9^{b}$ & $\mathrm{H}$ & $-\mathrm{OCH}_{3}$ & $\begin{array}{c}\mathrm{Ac}_{2} \mathrm{O} / \\
1 \text { eq. } \mathrm{AlCl}_{3}\end{array}$ & $-\mathrm{COCH}_{3}$ & - & $\overline{\mathrm{RT}}$ \\
\hline $10^{c}$ & $-\mathrm{COCH}_{3}$ & $-\mathrm{OCH}_{3}$ & 1 eq. $\mathrm{AlCl}_{3}$ & $-\mathrm{COCH}_{3}$ & Anh. THF & $66^{\circ} \mathrm{C}$ \\
\hline 11 & $\mathrm{H}$ & $\mathrm{H}$ & $\begin{array}{c}3 \text { eq. } \mathrm{Ac}_{2} \mathrm{O} / \\
\mathrm{AcOH}\end{array}$ & $-\mathrm{COCH}_{3}$ & - & $140^{\circ} \mathrm{C}$ \\
\hline
\end{tabular}




\begin{tabular}{|c|c|c|c|c|c|c|}
\hline $\mathbf{1 2}$ & $\mathrm{H}$ & $\mathrm{H}$ & $\begin{array}{c}6 \text { eq. } \mathrm{Ac}_{2} \mathrm{O} / \\
3 \text { eq. } \mathrm{H}_{2} \mathrm{SO}_{4}\end{array}$ & $-\mathrm{COCH}_{3}$ & - & RT \\
\hline $\mathbf{1 3}$ & $\mathrm{H}$ & $\mathrm{H}$ & $\mathrm{TFA}$ & $\mathrm{H}$ & - & $72{ }^{\circ} \mathrm{C}$, \\
\hline $\mathbf{1 4}$ & $\mathrm{H}$ & $\mathrm{H}$ & 1 mmol TFA & $\mathrm{H}$ & $\mathrm{MeOH}$ & $65^{\circ} \mathrm{C}$ \\
\hline Entry & $\mathbf{R}_{\mathbf{1}}$ & $\mathbf{R}_{\mathbf{2}}$ & Hot Catalyst & $\mathbf{R}_{\mathbf{3}}$ & Solvent & Temperature \\
\hline $\mathbf{1 5}$ & $\mathrm{H}$ & $\mathrm{H}$ & DMF & $\mathrm{H}$ & - & $153{ }^{\circ} \mathrm{C}$ \\
\hline $\mathbf{1 6}$ & $\mathrm{H}$ & $\mathrm{H}$ & $\mathrm{Ph}_{2} \mathrm{O}$ & $\mathrm{H}$ & - & $25{ }^{\circ} \mathrm{C}$ \\
\hline
\end{tabular}

$10 \mathrm{~mL}$ of solvent was used, reactions were stirred overnight. a) $25 \mathrm{~mL}$ of solvent, b) $1 \mathrm{M}$ solution was used, c) $5 \mathrm{~mL}$ of solvent was used.

Table 3: Different conditions attempted for the Gould-Jacobs cyclization reaction

From Table 3, the different conditions attempted for the ring closing reaction (Gould-Jacobs cyclization reaction) could be classified into 3 main categories; Lewis acids (entries 1-10), protic acids (entries 11-14) and high boiling point solvents (entries $15 \& 16$ ).

\subsubsection{Lewis acids:}

The general procedure of the Gould-Jacons reaction using Lewis acids (entries 1-8) is by treating a solution of compound $\mathbf{1}$ with either an equivalent or excess amount of the Lewis acid. After quenching the reaction mixture with anhydrous ethanol and evaporation of solvents under reduced pressure, NMR analysis was performed on the crude product. Complete recovery of the starting material was observed in all cases.

Trying to find better conditions, the addition of an electron donating group, e.g. methoxy group, on compound $\mathbf{1}$ was attempted to render the aryl group more electron rich and hence more 
reactive towards the cyclization reaction. Synthesis of compound 2, diethyl-2-(((4methoxyphenyl)amino)methylene)malonate, was done analogously to compound $\mathbf{1}$, but starting with $p$-anisidine instead of aniline. The reaction mixture was heated to reflux overnight followed by solvent evaporation to afford compound 2 in $96 \%$ yield after purification using column chromatography (Scheme 4).

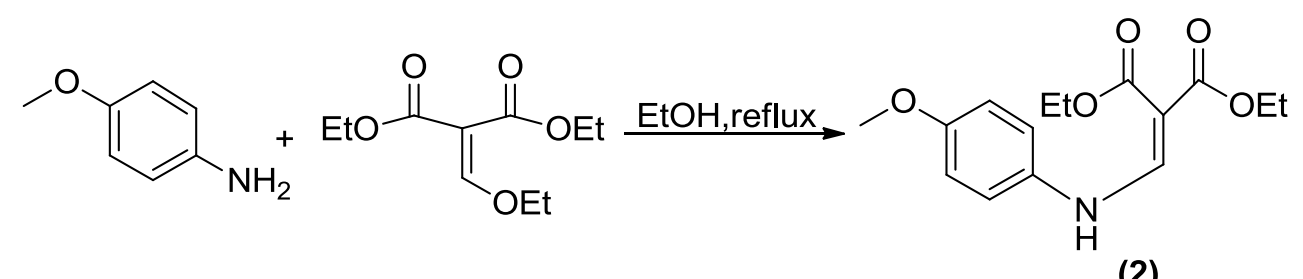

(2)

$96 \%$

Scheme 4: Synthesis of diethyl-2-(((4-methoxyphenyl)amino)methylene)malonate

The cyclization of compound 2 by its treatment with a mixture of $\mathrm{Ac}_{2} \mathrm{O} / \mathrm{AlCl}_{3}$, entry (9), did not work as hoped where the main product was recovered starting material.

The nitrogen atom found on compound $\mathbf{1}$ is Lewis basic, which may make it reactive towards the acid catalysts used in the Gould-Jacobs cyclization attempts. This feature can hinder the activation of the starting material at the right position and therefore justifying the failure of the reaction. Blocking the nitrogen group by the addition of an acetyl group was an attempt to decrease its reactivity. Unfortunately, the acetylation of compound $\mathbf{1}$ using $\mathrm{NaH}$ and $\mathrm{Ac}_{2} \mathrm{O}$ was unsuccessful.

It was also interesting to our group to make a compound bearing both methoxy and acetyl group, compound $\mathbf{3}$, since the electron-donating methoxy group was expected to increase the reactivity in the Gould-Jacobs reaction.

Synthesis of compound $\mathbf{3}$, diethyl 2-(( $N$-(4-methoxyphenyl)acetamido)methylene)malonate, carrying both methoxy and acetyl group, can be done by acetylation of compound 2 (Scheme 5). 
The deprotonation of compound 2 was done using an excess (4 eq.) of $\mathrm{NaH}$, followed by the addition of the acylating agent $\left(\mathrm{Ac}_{2} \mathrm{O}\right)$. After stirring at room temperature for 2 days, the reaction mixture was quenched with saturated ammonium chloride. The desired compound was isolated via column chromatography to afford compound $\mathbf{3}$ in $37 \%$ yield.<smiles>CCOC(=O)CNC(=O)Oc1ccc(N(C=C(C(=O)OCC)C(=O)OCC)C(C)=O)cc1</smiles>

Scheme 5: Synthesis of diethyl 2-((N-(4-methoxyphenyl)acetamido)methylene)malonate

For the cyclization reaction, compound 3 treated with 1 eq. of $\mathrm{AlCl}_{3}$, entry 10 . The reaction did not work well, unexpectedly affording $p$-anisidine as the product of decomposition.

\subsubsection{Acids:}

Different acids have been tried for the purpose of cyclizing compound 1, entries 11-13. Different conditions were also tried from using a solvent and stirring at room temperature, heating to reflux or by refluxing the acid neat. Unfortunately, none of these attempts succeeded to bring this reaction to completion.

\subsubsection{High boiling point solvents:}

High temperature can also be used to promote the Gould-Jacobs cyclization reaction. Heating of compound 1 to reflux in DMF $\left(153^{\circ} \mathrm{C}\right)$, entry 15 , failed to produce the desired compound. Diphenyl ether was used as another example of a high boiling point solvent $\left(\mathrm{bp}=258^{\circ} \mathrm{C}\right)$, entry 16. 
According to literature, ${ }^{43,44}$ heating compound $\mathbf{1}$ to reflux in $\mathrm{Ph}_{2} \mathrm{O}\left(258{ }^{\circ} \mathrm{C}\right)$ is the common way to make this heterocycle. A $1 \mathrm{M}$ solution of compound $\mathbf{1}$ in $\mathrm{Ph}_{2} \mathrm{O}$ was prepared and the mixture was heated to reflux using a heating mantle for $15 \mathrm{~min}$. Heating of the reaction mixture was also tried using an oil bath but vegetable oil decomposed, turning dark brown, and the mixture was not refluxed as the oil could not reach the boiling point of $\mathrm{Ph}_{2} \mathrm{O}$. For workup, the reaction mixture was added dropwise into excess of hexanes to precipitate the cyclized product, ethyl-4oxo-1,4-dihydroquinoline-3-carboxylate (compound 4), Scheme 6. Compound 4 was separated via filtration. The isolated compound was impure as determined by ${ }^{1} \mathrm{H}-\mathrm{NMR}$ spectroscopy. It had significant amount of $\mathrm{Ph}_{2} \mathrm{O}$ and other decomposition products. Impure compound $\mathbf{4}$ was carried through to the following step which is ester hydrolysis. Ester hydrolysis of compound 4 was performed following Vertex patent using $2 \mathrm{~N}$ solution of aqueous $\mathrm{NaOH}$ and heating to reflux overnight. After acidification using $2 \mathrm{~N} \mathrm{HCl}$, a pale white precipitate was formed and collected via filtration to afford the desired LHS, 4-oxo-1,4-dihydroquinoline-3-carboxylic acid (compound 5), in $21 \%$ yield over 3 steps (Scheme 6). In our attempts to increase the yield, we thought of not isolating compound $\mathbf{4}$ and trying a one pot synthesis where compound $\mathbf{4}$ will be formed in situ and $2 \mathrm{~N}$ aq. $\mathrm{NaOH}$ solution will be added directly to the reaction mixture. After heating to reflux overnight, the reaction was cooled to room temperature followed by an extraction against ethyl acetate to remove $\mathrm{Ph}_{2} \mathrm{O}$. The aqueous layer was then separated and acidified using $2 \mathrm{~N} \mathrm{HCl}$ yielding compound $\mathbf{5}$ as a precipitate (Scheme 6). Compound $\mathbf{5}$ was isolated, via filtration, pure in $52 \%$ yield over 3 steps. The one pot synthesis significantly improved the yield of compound $\mathbf{5}$. 


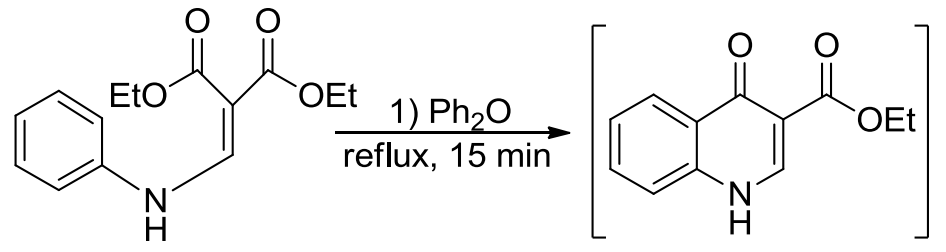

(4)<smiles></smiles>

(5)

Scheme 6: Synthesis of LHS using $\mathrm{Ph}_{2} \mathrm{O}$

The cyclization reaction of compound $\mathbf{1}$ was also tried by heating neat till melting for $15 \mathrm{~min}$, but the reaction did not work as the starting material was recovered quantitatively.

\subsubsection{Second Approach: Starting from ethoxymethylene Meldrum's acid:}

Another approach was followed towards the synthesis of LHS is starting from ethoxymethylene Meldrum's acid (compound 6). Ethoxymethylene Meldrum's acid is an intermediate for the synthesis of an enamine compound, 5-(((4-methoxyphenyl)amino)methylene)-2,2-dimethyl-1,3dioxane-4,6-dione (compound 7), that should be more reactive than compound $\mathbf{1}$ towards the Gould-Jacobs cyclization reaction. The expected increased reactivity of compound $\mathbf{7}$ is thought to be due to the presence of; a methoxy group that renders the aryl group more electron-rich, and the acetal that should be more readily activated by acids than the ester in compound $\mathbf{1}$. Synthesis of compound 7 was performed following the literature method by the condensation of $p$ anisidine with Meldrum's acid and triethyl orthoformate ${ }^{31}$ Meldrum's acid was dissolved in an excess of triethyl orthoformate and the mixture was heated to reflux for $1 \mathrm{hr}$ to form compound $\mathbf{6}$ in situ (Scheme 7a). An equivalent amount of $p$-anisidine was added along with DMF and heating was continued for an additional 2 hrs. $p$-Anisidine will undergo an addition-elimination reaction with ethoxymethylene Meldrum's acid, formed in situ to give the enamine intermediate (compound 7). ${ }^{31}$ After quenching with water, a dark brown solid was formed that was collected 
via filtration. The desired enamine intermediate was isolated by recrystallization from methanol to be separated as a yellow crystalline solid in $11 \%$ yield.

(a)

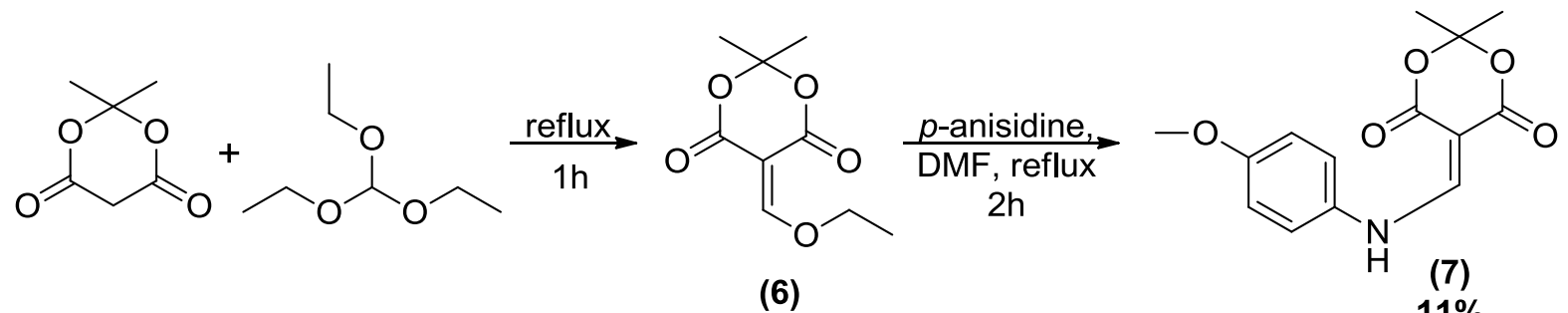

(6)

(b)

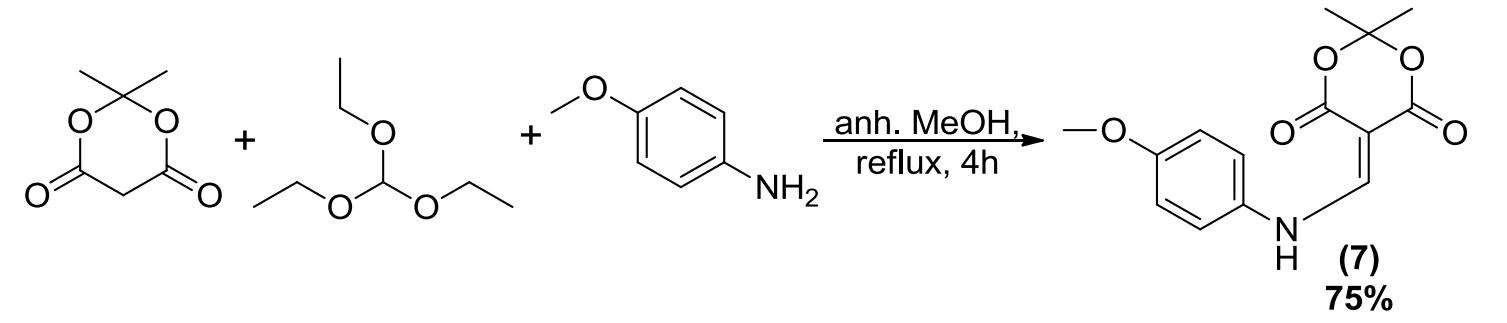

Scheme 7: Different ways for the synthesis of 5-(((4-methoxyphenyl)amino)methylene)-2,2dimethyl-1,3-dioxane-4,6-dione

In order to increase the yield of the previous reaction, some modifications were made. Anhydrous methanol was used as a solvent instead of triethyl orthoformate. A suspension of Meldrum's acid, 0.84 eq. of p-anisidine and 0.76 eq. of triethyl orthoformate in anhydrous methanol was heated to reflux for 4 hrs. After cooling to room temperature, the desired enamine compound was precipitated and isolated by filtration and the yield was determined to be $75 \%$ (Scheme 7b). The advantages of this method is the use of methanol as a solvent instead of triethyl orthoformate which is a more valuable reagent, lowering the temperature of reflux (bp of methanol $=65{ }^{\circ} \mathrm{C}$ and bp of triethyl orthoformate $=144-146{ }^{\circ} \mathrm{C}$ ) and the desired product was isolated pure, without the need of recrystallization, and in better yields.

The next step was to try different reagents for the intramolecular cyclization of compound 7. Different reagents and conditions are summarized in Table 4. 


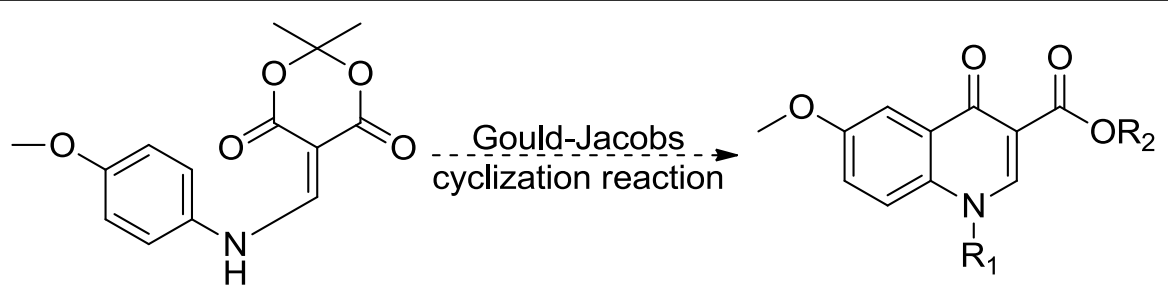

(7)

\begin{tabular}{|c|c|c|c|}
\hline Entry & Reagent & $\mathbf{R}_{\mathbf{1}}$ & $\mathbf{R}_{\mathbf{2}}$ \\
\hline $\mathbf{1}^{(\mathbf{a}, \mathrm{b})}$ & $p$-toluene sulfonic acid & $\mathrm{H}$ & $\mathrm{H}$ \\
\hline $\mathbf{2}^{(\mathrm{a}, \mathrm{b})}$ & $\mathrm{TFA}$ & $\mathrm{H}$ & $\mathrm{H}$ \\
\hline $\mathbf{3}^{(\mathbf{c})}$ & $\mathrm{Ac}_{2} \mathrm{O} / \mathrm{H}_{2} \mathrm{SO}_{4}$ & $-\mathrm{COCH}_{3}$ & $\mathrm{H}$ \\
\hline $\mathbf{4}^{(\mathbf{c})}$ & $\mathrm{Ac}_{2} \mathrm{O} / \mathrm{AlCl}_{3}$ & $-\mathrm{COCH}_{3}$ & $\mathrm{H}$ \\
\hline $\mathbf{5}^{\text {(c) }}$ & $\mathrm{Ac}_{2} \mathrm{O} / \mathrm{ZnBr}_{2}$ & & $\mathrm{H}$ \\
\hline $\mathbf{6}^{(\mathrm{a})}$ & $\mathrm{SOCl}_{2} / \mathrm{CHCl}_{3}$ & $-\mathrm{COCH}_{3}$ & $\mathrm{Cl}$ \\
\hline $\mathbf{7}^{(\mathbf{a})}$ & & $\mathrm{H}$ & $\mathrm{H}$ \\
\hline
\end{tabular}

(a) reflux, (b) $\mathrm{MeOH}$ was used as a solvent, (c) RT

Table 4: Different reagents attempted for the cyclization of compound 7

Different Lewis acids, acids and high boiling point solvents were tried for the cyclization reaction. The general procedure was dissolving compound 7 in a solvent, followed by the addition of an equivalent or an excess amount of the reagent. The reaction was stirred overnight and then quenched with water and extracted against an organic solvent. The main product isolated under all conditions, except for entry 6 , was $p$-anisidine. In entry 6 the starting material was recovered. The formation of $p$-anisidine is mainly due to a decomposition of the enamine. 


\subsubsection{Third Approach: Starting from Isatoic anhydride:}

Another approach that was pursued, the reaction of isatoic anhydride and methyl propiolate. It was hoped that isatoic anhydride would undergo an addition reaction with methyl propiolate to give the desired quinolinone compound (Scheme 8). Different solvents were used for this reaction and are summarized in table 5 .

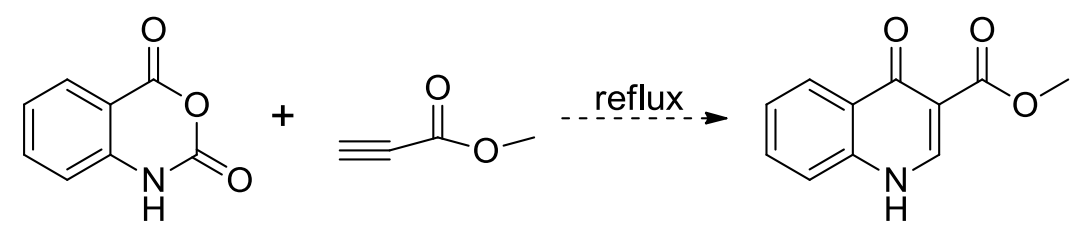

Scheme 8: Synthesis of quinolinone starting from isatoic anhydride

\begin{tabular}{|c|c|}
\hline Entry & Solvent \\
\hline $\mathbf{1}$ & Toluene \\
\hline $\mathbf{2}$ & Toluene, $0.05{\mathrm{mmol} \mathrm{Pd}\left(\mathrm{PPh}_{3}\right)_{4}}$ \\
\hline $\mathbf{3}$ & Methanol \\
\hline $\mathbf{4}$ & Methanol, $10 \mathrm{~mol}_{\mathrm{KO} \mathrm{KBu}}$ \\
\hline $\mathbf{5}$ & Methanol, 10 mol\% $\mathrm{H}_{2} \mathrm{SO}_{4}$ \\
\hline $\mathbf{6}$ & Chlorobenzene \\
\hline
\end{tabular}

Table 5: Different conditions tried for the synthesis of LHS starting from isatoic anhydride

The general procedure of the previous reaction is mixing both isatoic anhydride and methyl propiolate in one of the stated solvents along with the catalyst if used. The reaction mixture was heated to reflux overnight. After cooling to room temperature, the reaction was worked up by 
evaporation of solvents. None of the used acid, base, or selected transition metal catalysts (Pd catalyst) was observed to bring about the desired reaction. The main product of most of these reactions was methyl anthranilate. As an alternative pathway, methyl anthranilate, compound $\mathbf{8}$, was intentionally made and different bases or Lewis acids were tried for the purpose of cyclization. Isatoic anhydride was suspended in methanol and treated with an excess of a base, potassium tert-butoxide where elimination of a $\mathrm{CO}_{2}$ molecule will take place. The mixture was heated to reflux overnight. After cooling to room temperature, the reaction mixture was partitioned between water and ethyl acetate. The organic layer was then evaporated under reduced pressure to afford compound $\mathbf{8}$ quantitatively as a brown oil (Scheme 9).<smiles>C#CC(=O)OCC#CCOc1ccc(N)c(C(=O)OC)c1</smiles>

(8) $100 \%$

Scheme 9: Synthesis of methyl anthranilate and attempts for making quinolinone compound

For the purpose of making the quinolinone compound, methyl anthranilate was first deprotonated using $\mathrm{NaH}$ at room temperature. The resulting anion was envisioned to undergo conjugate addition to methyl propiolate and subsequently form the desired heterocycle (Figure 14). 


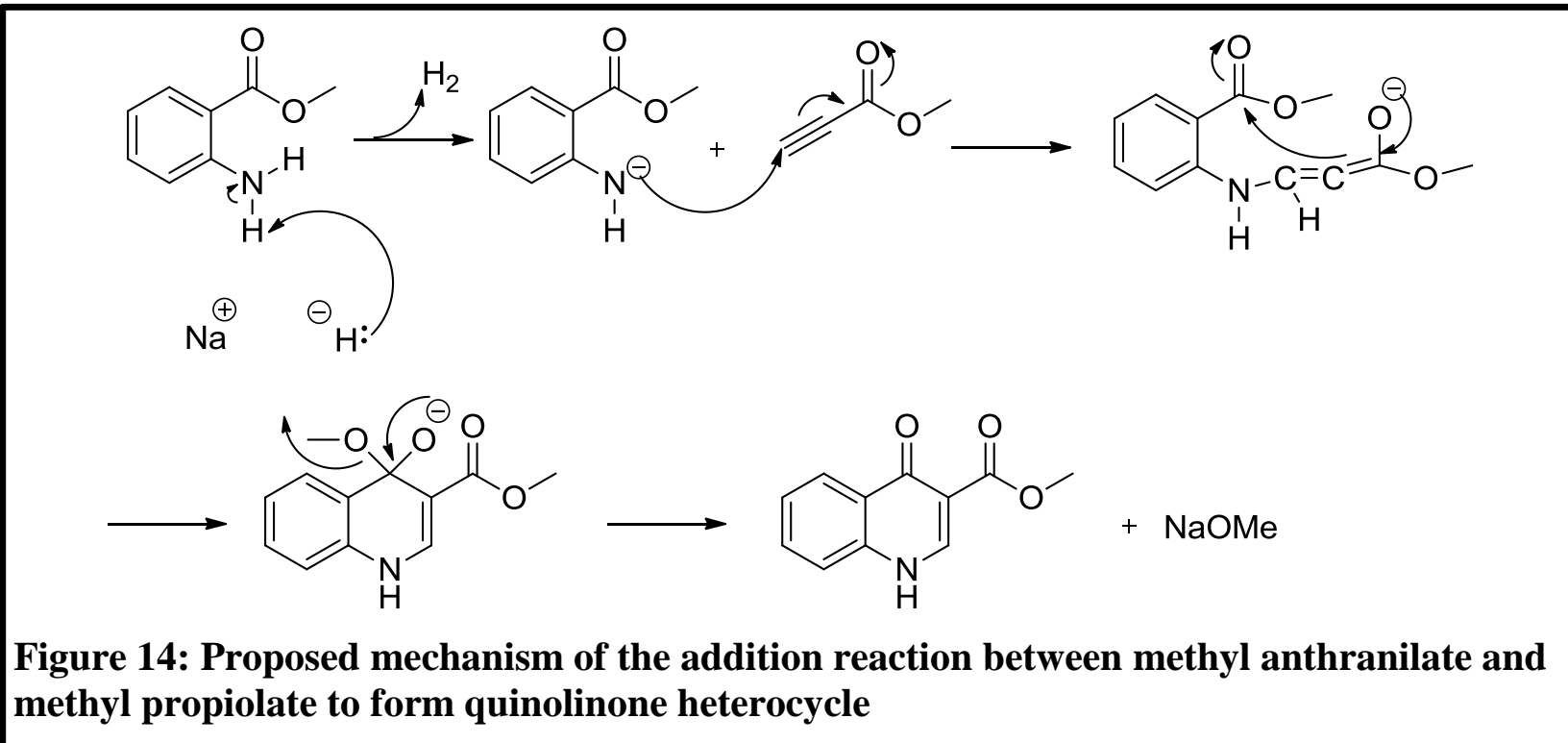

Different solvents with different polarities were tried for this reaction such as toluene, DMF and THF. Lewis acids, e.g. $\mathrm{ZnBr}_{2}$, were also tried for the activation of methyl anthranilate and to help the following addition reaction. Although the mechanism of the reaction seems plausible, none of the attempted conditions were successful at giving the desired product.

\subsubsection{Fourth Approach: Tandem reduction-addition-elimination reaction:}

A new way was pursued that is not based on the Gould-Jacobs reaction concept and does not require the use of Lewis acids for the formation of the desired LHS. This approach is an adaptation of the Leimgruber-Batcho reaction, which is usually used for synthesis of indoles. ${ }^{32}$ According to literature, synthesis of the desired heterocycle can be achieved via a three step sequence. $^{32}$ The first step involves treatment of monoethyl malonate, compound 9, with an excess of a strong base such as $n$-BuLi. The resulting dianion was reacted with 0.5 eq. of 2nitrobenzoyl chloride, compound 10, through a nucleophilic addition reaction to form (upon decarboxylative acidic workup) a ketoester, ethyl-3-(2-nitrophenyl)-3-oxopropanoate (compound 11). The second step is the conversion of the ketoester into enaminone, ethyl-3-(dimethylamino)2-(2-nitrobenoyl)acrylate (compound 12), via an addition reaction with $N, N$-dimethylformamide 
dimethyl acetal. The third and last step is a reduction of the nitro group by treatment with 0.6 eq. of hydrazine monohydrate and $10 \% \mathrm{Pd} / \mathrm{C}$. The primary amino group subsequently underwent in situ addition-elimination, expelling $\mathrm{Me}_{2} \mathrm{NH}$, to afford the desired LHS in good yield (Scheme 10).<smiles>CCOC(=O)CC(N)=C(C(=O)OCC)C(=O)c1ccccc1[N+](=O)[O-]</smiles>

(12)

$89 \%$<smiles>CCOC(=O)CC(=O)c1ccccc1[N+](=O)[O-]</smiles>

(11)

$87 \%$<smiles>CCOC(=O)c1c[nH]c2ccccc2c1=O</smiles>

(4)

$78 \%$

Scheme 10: Synthesis of quinolinone via tandem reduction-addition elimination reaction $^{32}$

Following the literature method, the reactions described above were attempted. Monoethyl malonate was first made by ester hydrolysis of diethyl malonate using 1 eq. of $\mathrm{NaOH}$ to make the salt, followed by acidification using conc. $\mathrm{HCl}^{33}$ Ethanol was used as a solvent to avoid transesterification and the desired monoester was separated by column chromatography as a light yellow oil in a $60 \%$ yield (Scheme 11$)$.<smiles>CCOC(=O)CC(=O)OCCO[NbH2]O</smiles>

(9)

$60 \%$

Scheme 11: Synthesis of monoethyl malonate 
2-Nitrobenzoyl chloride, compound 10, was formed by reacting 2-nitrobenzoic acid with an excess of thionyl chloride along with a catalytic amount of DMF in chloroform (Scheme 12). The reaction mixture was refluxed for $5 \mathrm{hrs}$ and then the solvent was removed to give compound 10 quantitatively. DMF was added to the reaction mixture to form a stronger chlorinating agent with thionyl chloride as the reaction was tried with just thionyl chloride but the starting material was totally recovered.

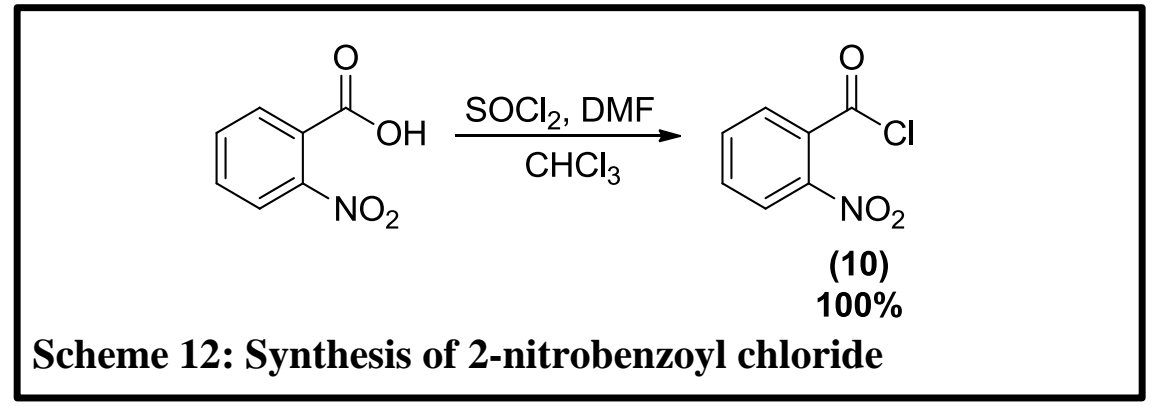

The addition reaction between compounds $\mathbf{9}$ and $\mathbf{1 0}$ was done following the literature procedure. $^{32}$ The reaction was done under inert atmosphere and it involved cooling a solution of monoethyl malonate in THF to $-87^{\circ} \mathrm{C}$ using ethyl acetate slush bath. 1.01 eq. of $2 \mathrm{M}$ solution of $n$-BuLi in hexanes was then added dropwise to convert monoethyl malonate into its dianion. An internal indicator, 2,2 -bipyridyl (BIPY), was used to check the full conversion of monoethyl malonate as it will turn red once reacted with $n$-BuLi. The reaction mixture was then warmed to $\sim-10{ }^{\circ} \mathrm{C}$ and another 1.01 eq. portion of $2 \mathrm{M} \mathrm{n}$-BuLi was added until a red color persisted for 5 min. The mixture was cooled back to $-87^{\circ} \mathrm{C}$, and a solution of 2-nitrobenzoyl chloride in THF was added dropwise over $25 \mathrm{~min}$. The resulting yellow suspension was warmed slowly to $0{ }^{\circ} \mathrm{C}$. Following an acidic workup, compound $\mathbf{1 1}$ was isolated as a reddish orange oil in a crude yield of $97 \%$. Compound $\mathbf{1 1}$ was carried to the next step without further purification (Scheme 10). This method has some downsides; such as the use of a slush bath to reach that low temperature and the careful manipulation of the moisture sensitive $n$-BuLi. In order to avoid these drawbacks, 
an alternative method was pursued to make compound 11 using $\mathrm{Et}_{3} \mathrm{~N}$ and $\mathrm{MgCl}_{2}\left(\mathrm{Scheme}_{13)}{ }^{34}\right.$ This method entailed the addition of 2 eq. of $\mathrm{Et}_{3} \mathrm{~N}$ followed by the addition of 1.2 eq. of $\mathrm{MgCl}_{2}$ to an ice cold solution of monoethyl malonate in anhydrous acetonitrile. Stirring was continued at room temperature for $2.5 \mathrm{hrs}$. The reaction mixture was recooled to $0{ }^{\circ} \mathrm{C}$ and 0.5 eq. of 2 nitrobenzoyl chloride was added dropwise followed by the addition of a small portion of $\mathrm{Et}_{3} \mathrm{~N}$ (0.1 eq.) and stirring was continued at room temperature overnight. ${ }^{34}$ Acetonitrile was removed by rotary evaporation and an acidic extraction $(12 \%$ aq. $\mathrm{HCl})$ against toluene was done to afford compound $\mathbf{1 1}$ in $97 \%$ crude yield (Scheme 13).

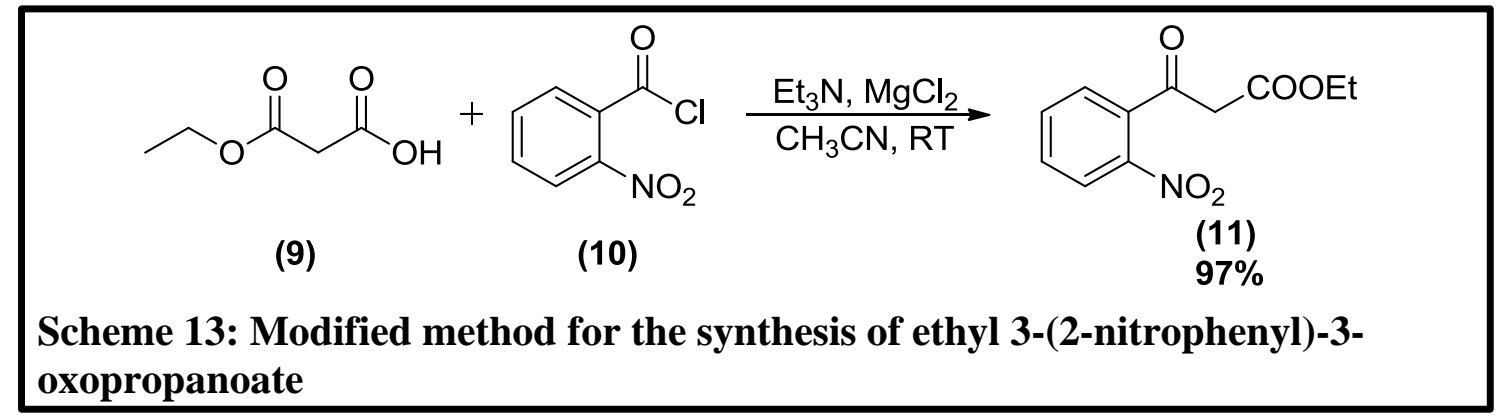

Synthesis of compound $\mathbf{1 2}$ was done following the literature. ${ }^{32}$ To a solution of compound $\mathbf{1 1}$ in DMF, 1 eq. of $N, N$-dimethylformamide dimethyl acetal was added and the temperature was kept at $100{ }^{\circ} \mathrm{C}$ overnight (Scheme 10). The reaction mixture was quenched with ice cooled water and the desired compound $\mathbf{1 2}$ was isolated after extraction as an orange yellow oil in $72 \%$ crude yield. The resulting compound was used in the next step without further purification. The last step in this sequence is the reductive cyclization of compound $\mathbf{1 2}$ using hydrazine monohydrate. Following the literature procedure, compound 12 was dissolved in ethanol and 0.6 eq. of hydrazine monohydrate was added followed by $5 \% \mathrm{Pd} / \mathrm{C} .^{32}$ The reaction mixture was stirred at room temperature for $3 \mathrm{hrs}$. The reaction mixture was then heated to $70{ }^{\circ} \mathrm{C}$ for $0.5 \mathrm{hr}$ to avoid any precipitation. The hot solution was filtered through Celite to remove $\mathrm{Pd} / \mathrm{C}$ and the solvent 
was removed under reduced pressure. By NMR spectroscopic analysis, the main product of this reaction was not the desired quinolone compound (4), as claimed in the literature method, but it was the $N$-hydroxy quinolinone compound, 13, instead (Scheme 14). The formation of ethyl-1hydroxy-4-oxo-1,4-dihydroquinoline-3-carboxylate, compound $\mathbf{1 3}$, means that the reduction reaction was not complete.<smiles></smiles>

(12)

(13)

Scheme 14: Formation of ethyl-1-hydroxy-4-oxo-1,4-dihydroquinoline-3carboxylate

Having an incomplete reduction suggests the use of either more equivalents of hydrazine monohydrate or a stronger reducing reagent. More equivalents of hydrazine monohydrate (2 eq.) were used, following the same literature procedure, but compound $\mathbf{1 3}$ was still the main product. Stannous chloride dihydrate was tried as a different reducing reagent for the reductive cyclization step. To a solution of compound 12 in ethanol, 5 eq. of $\mathrm{SnCl}_{2} \cdot 2 \mathrm{H}_{2} \mathrm{O}$ was added and the mixture was heated to reflux overnight. ${ }^{35}$ From the crude NMR, the desired product was observed, but only in low yields.

In conclusion, different approaches have been attempted for the purpose of making the LHS. So far, the only successful way is by refluxing phenylamino malonate, compound $\mathbf{1}$, in $\mathrm{Ph}_{2} \mathrm{O}$ followed by ester hydrolysis in one pot.

Future work that can be done in the context of making the LHS, better reduction conditions can be tried for the reductive cyclization of compound 12. Also making the diacid chloride of compound 1 and its treatment with different Lewis acids can be a good way for making the LHS. 
The diacid chloride is supposed to be more reactive towards Friedel-Crafts-type acylation reaction.

\subsection{Towards the Synthesis of 5-amino-2,4-di-tert-butyl phenol (RHS):}

The Vertex patented procedure, (Scheme 1b), was followed in order to make the desired

aminphenol (RHS). ${ }^{45}$ The first step includes a base-catalyzed esterification of 2,4-di-tertbutylphenol. To a solution of 2,4-di-t-butylphenol in DCM, DMAP was added along with $\mathrm{Et}_{3} \mathrm{~N}$ to deprotonate the phenol. Methyl chloroformate was then added dropwise to act as an electrophile and the mixture was stirred at room temperature overnight. The desired 2,4-di-tertbutylphenylmethylcarbonate, compound 14, was isolated by column chromatography as a yellow oil in $87 \%$ yield (Scheme 1b). The next step is the nitration of the resulting methyl carbonate using a mixture of conc. $\mathrm{HNO}_{3}$ and conc. $\mathrm{H}_{2} \mathrm{SO}_{4}$. The procedure entailed the dropwise addition of a cold mixture of $\mathrm{HNO}_{3} / \mathrm{H}_{2} \mathrm{SO}_{4}$ to an ice cold solution of compound 14 in conc. $\mathrm{H}_{2} \mathrm{SO}_{4}$. The mixture was warmed to room temperature and stirring was continued overnight. The desired meta nitro compound was not the isolated product. By NMR, there was only one resonance in the aromatic region which suggests dinitration.

To avoid dinitration or the formation of any other undesired nitro isomers, i.e. ortho, different pathways have been pursued.

\subsubsection{Introduction of a bulky group:}

It was hypothesized that the introduction of a bulkier group on the 2,4-di-tert-butylphenyl ester might prevent over nitration or nitration at the ortho position. The pivalate ester was chosen as a good example of a bulky group that might sterically hinder the nitration at the ortho position and therefore favoring the meta nitration. 2,4-Di-tert-butylphenyl pivalate, compound 15, was made 
following the same procedure as compound $\mathbf{1 4}$ and it was isolated as a yellow solid in $67 \%$ yield (Scheme 15).

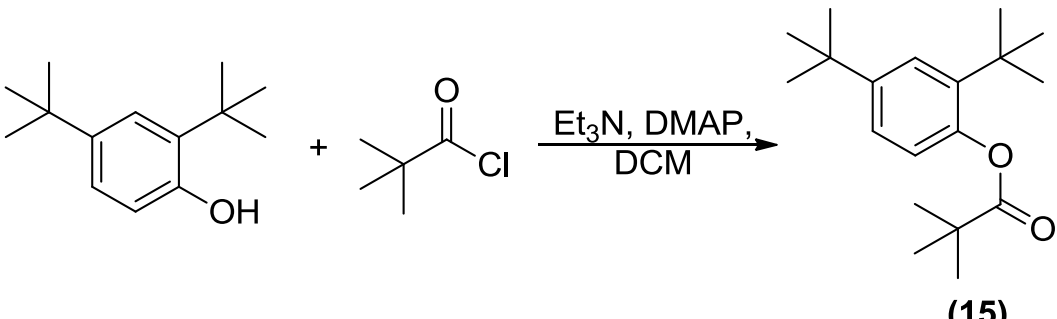

(15)

Scheme 15: Synthesis of 2,4-di-tert-butylphenyl pivalate

Nitration of the pivalate ester was attempted using the patent procedure, $\mathrm{HNO}_{3} / \mathrm{H}_{2} \mathrm{SO}_{4}$. The reaction did not work well as decomposition compounds, such as the loss of $t$-butyl groups, were the main products.

Other conditions were attempted, such as using $\mathrm{HNO}_{3}, \mathrm{Ac}_{2} \mathrm{O}$ and $\mathrm{AcOH}$. The pivalate ester was dissolved in a mixture of $\mathrm{Ac}_{2} \mathrm{O} / \mathrm{AcOH}$ and the reaction mixture was heated to $90{ }^{\circ} \mathrm{C}$. $\mathrm{HNO}_{3}$ was added dropwise and the reaction mixture was heated to reflux for $5 \mathrm{hrs}$. By NMR, no nitration was observed.

An alternative method was pursued using $\mathrm{HNO}_{3}$ and $\mathrm{Ac}_{2} \mathrm{O}$ and $\mathrm{CCl}_{4}$ as a solvent. This method involved the dropwise addition of a solution of the pivalate ester in $\mathrm{CCl}_{4}$ to an ice cold mixture of $\mathrm{HNO}_{3} / \mathrm{Ac}_{2} \mathrm{O}$. The reaction mixture was stirred at room temperature overnight. By NMR, the starting material was the only species present.

Other nitrating reagents, e.g. $\mathrm{KNO}_{3}$, were also attempted. The pivalate ester was added as a solid to a $1 \mathrm{M}$ solution of $\mathrm{KNO}_{3}$ in $\mathrm{H}_{2} \mathrm{SO}_{4}$. The reaction mixture was stirred at room temperature overnight. By NMR, the undesired $o$-nitro isomer was the main product. 


\subsubsection{Introduction of an electron withdrawing group:}

The addition of an electron withdrawing group, such as mesylate group, may decrease the reactivity of the ortho position towards nitration, thus favoring the formation of the meta isomer. Synthesis of the mesylate ester was done by the deprotonation of 2,4-di-tert-butylphenol using pyridine, followed by an electrophilic substitution using mesyl chloride. ${ }^{36}$ The reaction mixture was stirred at room temperature for $5 \mathrm{hrs}$ and the product, 2,4-di-tert-butylphenyl methanesulfonate (compound 16), was separated and purified by column chromatography as a white solid in a 75\% yield (Scheme 16).

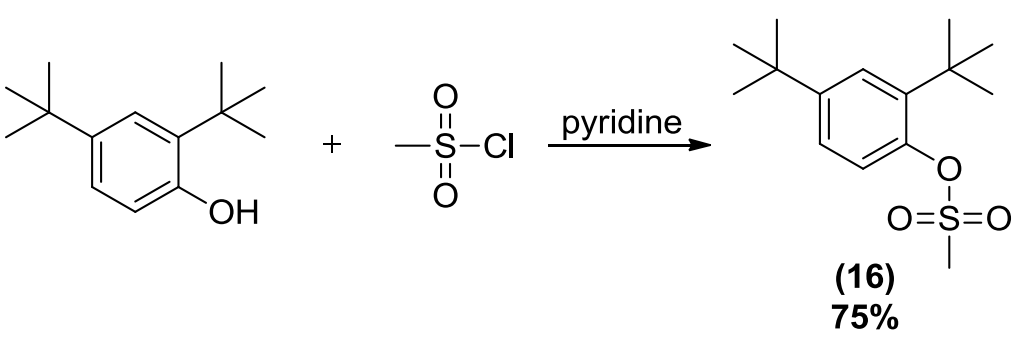

Scheme 16: Synthesis of 2,4-di-tert-butylphenyl methanesulfonate

Nitration of the di-t-butylphenyl mesylate, compound 16, was done following the literature method using a mixture of $\mathrm{HNO}_{3}$ and $\mathrm{H}_{2} \mathrm{SO}_{4}{ }^{36}$ The procedure involves the slow addition of an ice cold mixture of 1 eq. of $67 \% \mathrm{HNO}_{3}$ and conc. $\mathrm{H}_{2} \mathrm{SO}_{4}$ to the previously prepared suspension of compound 16 in conc. $\mathrm{H}_{2} \mathrm{SO}_{4}$ at $0{ }^{\circ} \mathrm{C}$. The reaction mixture was stirred at $0{ }^{\circ} \mathrm{C}$ for $3 \mathrm{hrs}$, and then poured onto ice. After extraction, a black oil was isolated and checked by NMR. No nitration was observed and the starting material was recovered. A possible reason that nitration of compound $\mathbf{1 6}$ was not observed is that more concentrated nitric acid was needed.

Following the same procedure, $67 \% \mathrm{HNO}_{3}$ was replaced by red fuming nitric acid (99.5\%). After checking by NMR, it was found that the starting material was recovered. In order to allow 
the nitration reaction, more equivalents of the red fuming $\mathrm{HNO}_{3}$ were used. The same literature procedure was followed with the use of an ice cold mixture of 5 eq. of $99.5 \% \mathrm{HNO}_{3}$ and conc. $\mathrm{H}_{2} \mathrm{SO}_{4}$. By NMR, the nitration reaction seemed to be happening. The product of the nitration reaction was carried through the next step directly without further purification.

The next mesylate hydrolysis step was done using aq. $\mathrm{NaOH}^{36}$ A suspension of the crude starting material in $4.06 \mathrm{M}$ aq. $\mathrm{NaOH}$ was heated to $65^{\circ} \mathrm{C}$ for $3 \mathrm{hrs}$. After an acidic workup, characterization of the isolated product was done using NMR. The hydrolysis reaction did not work as expected, as the mesylate peak was observed. The reaction was repeated but using an organic solvent, e.g. $\mathrm{MeOH}$, instead of $\mathrm{H}_{2} \mathrm{O}$. The mesylate peak disappeared indicating the complete hydrolysis of the mesylate ester. Following column chromatography, the desired meta isomer was isolated but in only $10 \%$ yield while the rest was a mixture of the other nitro isomer, ortho, and decomposition products. Both nitro isomers (Figure 15) can be differentiated by NMR according to their coupling patterns. For the ortho isomer, the two aromatic protons are coupled to each other through four bonds, thus they will appear as two doublets. While for the meta isomer, there is no coupling through five bonds and therefore they will appear as two singlets.

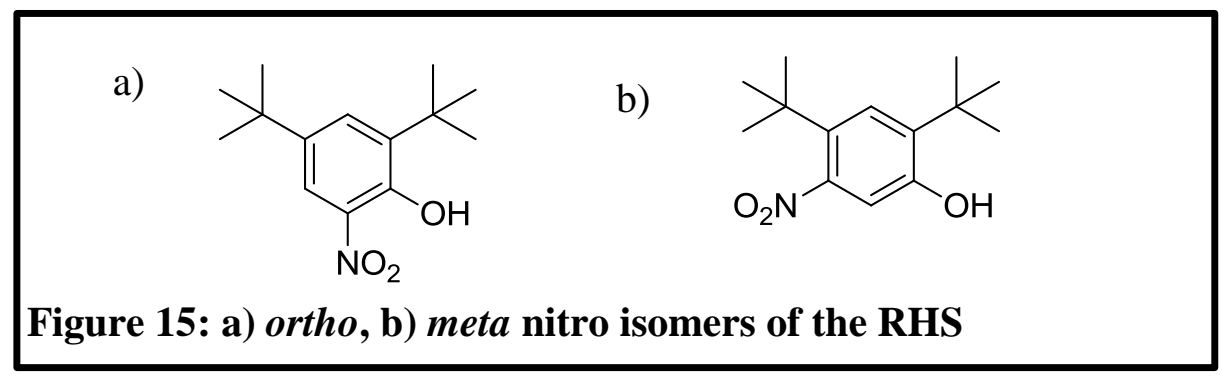

Using more equivalents of red fuming $\mathrm{HNO}_{3}, 6$ eq., was attempted but the isolated product was the undesired ortho compound. 
Nitration of compound $\mathbf{1 6}$ was also tried using a mixture of $\mathrm{HNO}_{3}, \mathrm{AcOH}$ and $\mathrm{Ac} \mathrm{c}_{2} \mathrm{O}$. A hot solution of compound 16 in $\mathrm{AcOH}$ and $\mathrm{Ac}_{2} \mathrm{O}$ was treated with $\mathrm{HNO}_{3}$. The reaction mixture was heated to $100{ }^{\circ} \mathrm{C}$ for $2 \mathrm{hrs}$. The starting material was recovered with no nitration being observed.

\subsubsection{Blocking the ortho position on the RHS:}

Blocking the ortho position, where the nitration happens mostly, by the addition of an iodo group was an alternative pathway we followed to favor the nitration at the desired position.

Synthesis of 2,4-di-tert-butyl-6-iodophenol, compound 17, was done following the literature. ${ }^{37}$ The literature procedure involves the portionwise addition of $N$-iodosuccinimide to a solution of 2,4-di-tert-butylphenol and 0.1 eq. of $p$-toluene sulfonic acid in DCM. Following an electrophilic substitution reaction, the iodination will proceed at the most electron rich position, ortho to the hydroxyl group, of the aromatic ring. After stirring at room temperature overnight, the reaction mixture was quenched with $10 \%$ aq. ascorbic acid and extracted with DCM. The desired compound was purified via column chromatography and isolated as a light yellow solid in very good yield (Scheme 17).

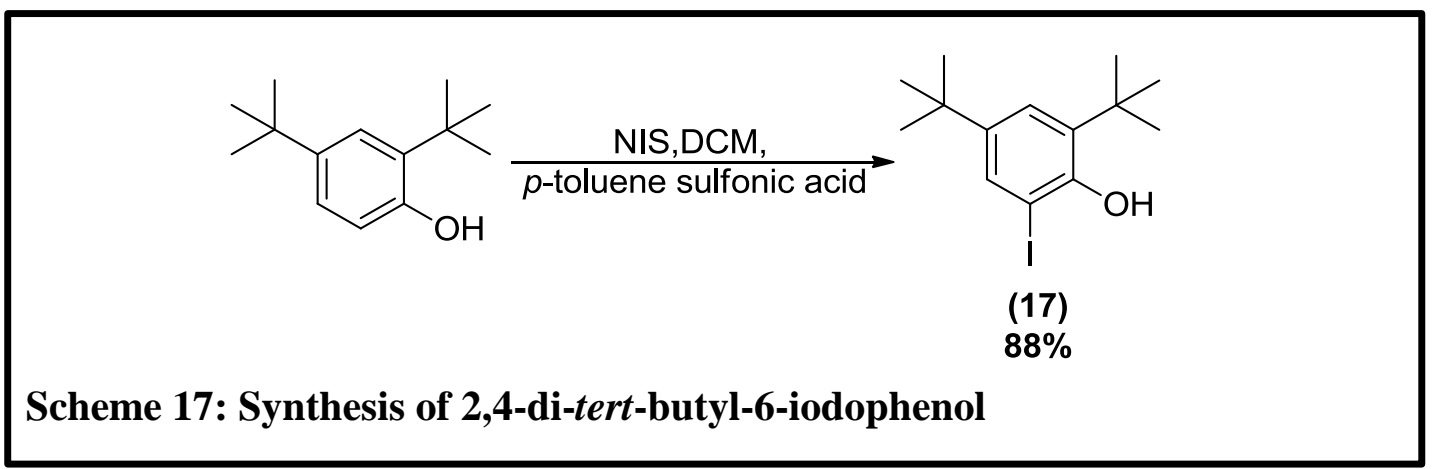

Nitration of compound 17 was done using a mixture of 1 eq. $99.5 \% \mathrm{HNO}_{3}$ and $\mathrm{H}_{2} \mathrm{SO}_{4}$ following

a literature procedure. ${ }^{36}$ To a suspension of 17 in $\mathrm{H}_{2} \mathrm{SO}_{4}$, an ice cold mixture of $\mathrm{HNO}_{3}$ and $\mathrm{H}_{2} \mathrm{SO}_{4}$ was added dropwise over $1 \mathrm{hr}$ at $0{ }^{\circ} \mathrm{C}$. During the addition, dark red fumes were forming. 
The reaction mixture was stirred in ice bath for $1 \mathrm{hr}$, then poured onto ice and extracted with ether. By NMR analysis of the crude reaction mixture, the desired product was observed but in low percentage, where the mixture was mostly unreacted starting material and some decomposition products.

To increase the percentage of the desired product, more equivalents of $\mathrm{HNO}_{3}$ were used. The reaction was repeated using 5 eq. of $\mathrm{HNO}_{3} / \mathrm{H}_{2} \mathrm{SO}_{4}$. The percentage of the desired compound increased with no unreacted starting material, but the crude reaction mixture contained other decomposition products.

Slight changes to the previous procedure were attempted, in order to reduce the amount of decomposition products and increase the yield, such as the addition of $\mathbf{1 7}$ as a solid or as a solution in DCM and the stepwise addition of $\mathrm{H}_{2} \mathrm{SO}_{4}$ and $\mathrm{HNO}_{3}$. Unfortunately, these changes were not successful at increasing the yield of the desired product.

In conclusion, the synthesis of the RHS is still under progress. The different approaches attempted were not successful to make the nitro isomer with the desired regiochemistry in good yields. Alternative pathways, such as the synthesis of a less electron rich benzene ring or microwave synthesis, can be followed in the future in order to synthesize the RHS in good yields.

\subsection{Synthesis of VX770 fragments:}

We were interested in making fragments of VX770 by coupling the LHS to some commercially available amines. These amines were missing one or more of the functional groups of the original RHS, i.e. $t$-butyl and $-\mathrm{OH}$ groups. The idea of making these fragments was to test their ability to interact with the CFTR protein and to compare their activity with that of VX770. The results of such biochemical assays may inform us as to which (if any) of the functional groups on 
the RHS are essential for biological activity, and which can be modified or omitted in the synthesis of molecular probes.

Three fragments were made; $N$-(4-(tert-butyl)phenyl)-4-oxo-1,4-dihydroquinoline-3carboxamide (18), $N$-(2-(tert-butyl)phenyl)-4-oxo-1,4-dihydroquinoline-3-carboxamide (19), and $N$-(3-hydroxyphenyl)-4-oxo-1,4-dihydroquinoline-3-carboxamide (20) (Scheme 18). The synthesis of the three fragments was done following the Vertex patent where HBTU was used as a peptide coupling reagent. ${ }^{45}$ First, the LHS was activated by $\mathrm{HBTU}$ and $\mathrm{Et}_{3} \mathrm{~N}$ at room temperature, followed by the portionwise addition of 1 eq. of the amine. The reaction mixture was stirred at room temperature overnight. The desired product was isolated after several extractions. The yield of these coupling reactions was very low, $\sim 20 \%$ in all cases.

In order to increase the yield, the previous procedure was slightly modified. The DMF solvent was replaced with a lower boiling point solvent, such as DCM, and more equivalents of the amine were used (Scheme 18).

The coupling reactions were repeated and the yields were dramatically improved in case of compounds 18 and 19. In case of compound 20, the yield slightly increased from $12 \%$ to $18 \%$. The purity of all three fragments; 18, 19, 20, was tested by HPLC. The HPLC chromatogram showed that all three fragments are pure and ready for biological testing. 


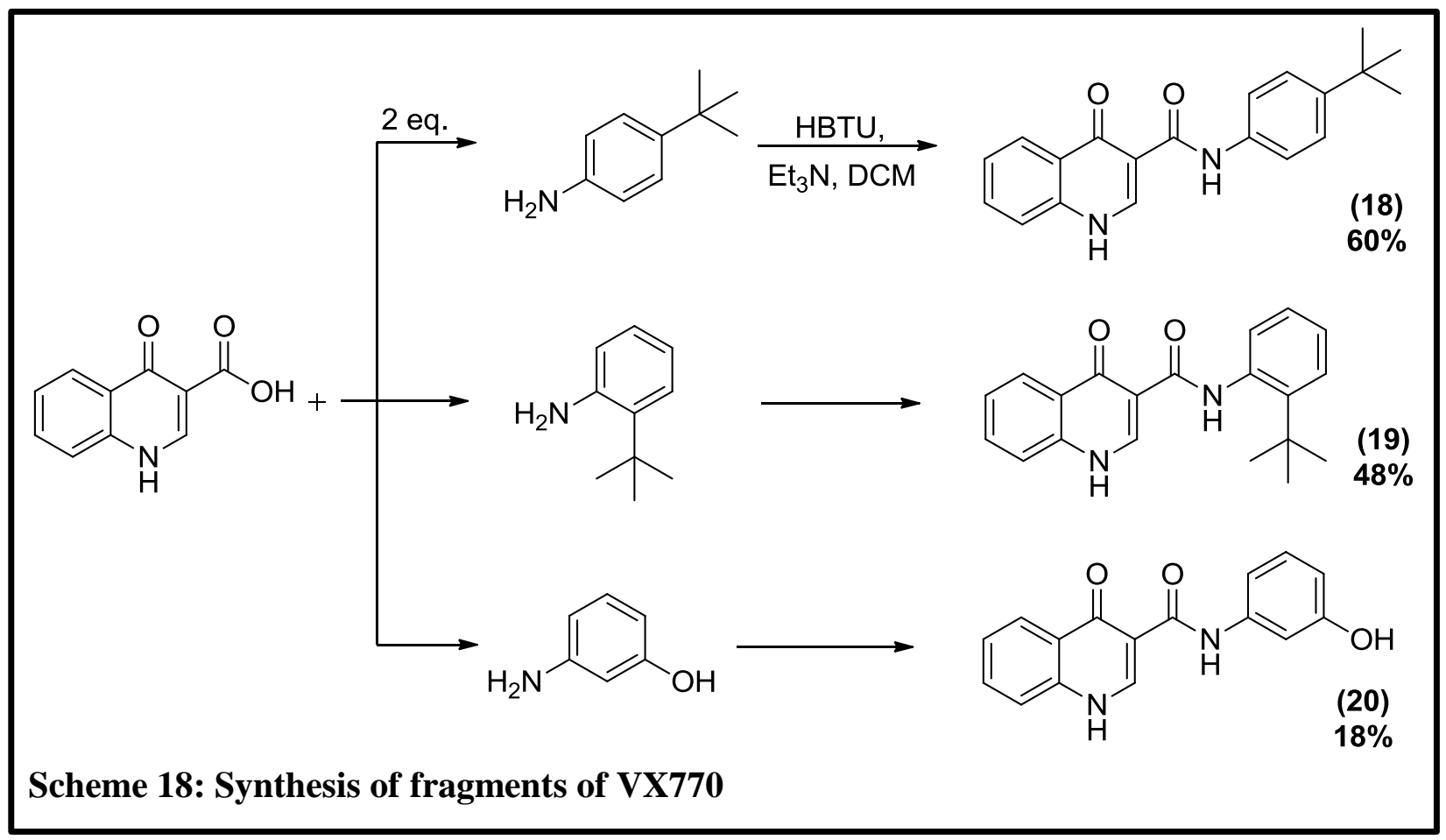

We were also interested in testing the activity of $N$-(4-butoxyphenyl)-4-oxo-1,4dihydroquinoline-3-carboxamide, compound 21. This compound bears a bulky group, OBu, at the para position. This big group simulates the presence of a longer tether, e.g. tetraethylene glycol, that can be coupled with agarose beads to be used as a solid support for the purpose of affinity chromatography. Synthesis of $\mathbf{2 1}$ was done using the previous procedure, but the yield was very low (7\%). To improve this yield, DMAP was added. The LHS was suspended along HBTU in DCM. $\mathrm{Et}_{3} \mathrm{~N}$ and $10 \mathrm{~mol} \%$ of DMAP were added, followed by the amine (Scheme 19). The desired compound precipitated from the solution after stirring at room temperature overnight. The yield increased significantly from $7 \%$ to $52 \%$. 


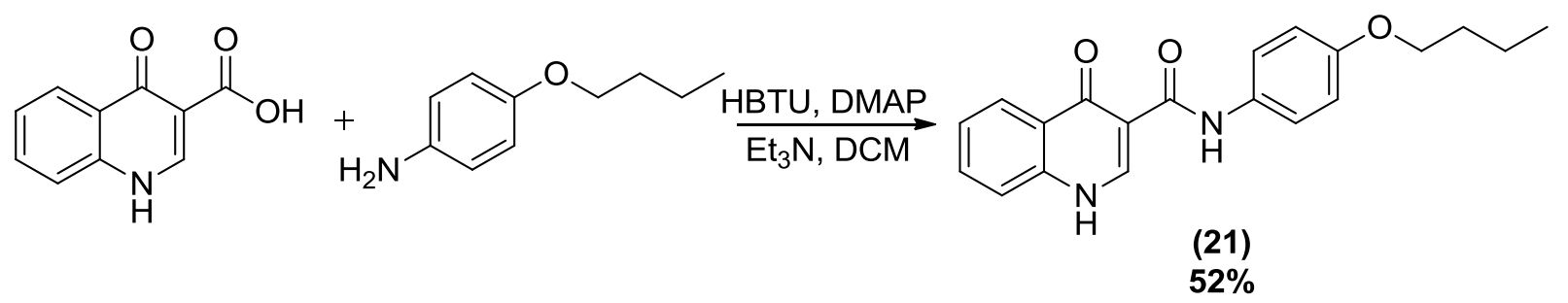

Scheme 19: Synthesis of $N$-(4-butoxyphenyl)-4-oxo-1,4-dihydroquinoline-3-carboxamide

\subsection{Towards the Synthesis of Labeled Derivatives:}

\subsubsection{Synthesis of Azido Photoaffinity Label:}

Synthesis of photoaffinity labels is important to identify the exact site of interaction between the drug and the CFTR protein. We were able to make a fluoro azido derivative of the LHS of VX770. 7-Azido-1-(tert-butyl)-6-fluoro-4-oxo-1,4-dihydroquinoline-3-carboxylic acid was made through six steps (Scheme 20). The first step, analogous to the chemistry described in section 2.1.4 of this thesis, involved the activation of monoethyl malonate, using $\mathrm{Et}_{3} \mathrm{~N}$ and $\mathrm{MgCl}_{2}$, to form a strong nucleophile that can attack the electrophilic carbonyl carbon on 2,4,5trifluorobenzoyl chloride to give ethyl-3-oxo-3-(2,4,5-trifluorophenyl)propanoate (compound 22) ${ }^{34}$ The next step is an addition reaction by reacting $\mathbf{2 2}$ with $N, N$-dimethylformamide dimethyl acetal in DMF and heating for 2 hrs to afford ethyl-3-(dimethylamino)-2-(2,4,5trifluorobenzoyl)acrylate (compound $\mathbf{2 3}$ ) ${ }^{32}$ The formed tertiary amine compound was converted into a secondary amine through an amine exchange reaction using $t$-butylamine and a mixture of ether/ethanol as a solvent. The reaction mixture was stirred at room temperature for $5 \mathrm{hrs}$ to afford the desired product, (Z)-ethyl-3-(tert-butylamino)-2-(2,4,5-trifluorobenzoyl)acrylate (compound 24). ${ }^{38}$ Compound 24 was then deprotonated using $\mathrm{NaH}$ and the resulting anion underwent intramolecular nucleophilic aromatic substitution on carbon 2 on the phenyl ring to form the desired heterocycle, ethyl-1-(tert-butyl)-6,7-difluoro-4-oxo-1,4-dihydroquinoline-3- 
carboxylate (compound 25) in 30\% yield over 4 steps. ${ }^{39}$ The fifth step is fluoro azido substitution reaction. A solution of compound 25 in DMSO was treated with 5 eq. of $\mathrm{NaN}_{3}$ and the reaction mixture was heated to $100{ }^{\circ} \mathrm{C}$ overnight to give ethyl-7-azido-1-(tert-butyl)-6-fluoro-4-oxo-1,4dihydroquinoline-3-carboxylate (compound 26) as a yellow solid in $30 \%$ yield. The last step involved ester hydrolysis of 26 using $2 \mathrm{~N}$ aq. $\mathrm{NaOH}$. After acidification with $2 \mathrm{~N} \mathrm{HCl}$, the desired product, 7-azido-1-(tert-butyl)-6-fluoro-4-oxo-1,4-dihydroquinoline-3-carboxylic acid (compound 27), precipitated and was collected by filtration as a yellow solid in $72 \%$ yield. It was hoped that the hydrolysis of the $t$-butyl amine would take place in one step along with ester hydrolysis, by acidification to $\mathrm{pH} 1$, but this was not observed to be the case.<smiles>CCOC(=O)CC(=O)OCC</smiles>

(22)<smiles>CCOC(=O)C(=CNC(C)(C)C)C(=O)c1cc(F)c(F)cc1C(=O)C(=CN(C)C)C(=O)c1cc(F)c(F)cc1F</smiles><smiles>CCOC(=O)c1cn(C(C)(C)C)c2cc(F)c(F)cc2c1=O</smiles>

(25)

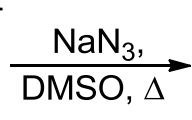<smiles>CCOC(=O)c1cn(C(C)(C)C)c2cc(N)c(F)cc2c1=O</smiles>

(26)

$\stackrel{\text { 1) aq. } \mathrm{NaOH}}{\longrightarrow}$ 2) $\mathrm{HCl}$<smiles>CC(C)(C)n1cc(C(=O)O)c(=O)c2cc(F)c(N)cc21</smiles>

(27)

Scheme 20: Synthesis of 7-azido-1-(tert-butyl)-6-fluoro-4-oxo-1,4dihydroquinoline-3-carboxylic acid 
The last step in making the photoaffinity label is coupling the azido LHS (27) to the amine part. 4-t-Butylaniline was used as the RHS in this case. The coupling reaction was performed analogously to compound 21 affording the desired product, 28 (Scheme 21). The reaction was done on a small scale $(0.033 \mathrm{mmol}$ of the carboxylic acid) using large excess of the amine (5 eq.), HBTU (5 eq.), 9.7 eq. of the base and $10 \mathrm{~mol} \%$ of the DMAP. After several extractions, the mass of the collected material was $6 \mathrm{mg}$. By NMR spectroscopic analysis of the crude material, the desired product (28) was present. Due to the small amount of the collected material, the purification was not attempted. In the future, the reaction may be repeated on a larger scale in order to isolate useful amounts of the desired product.

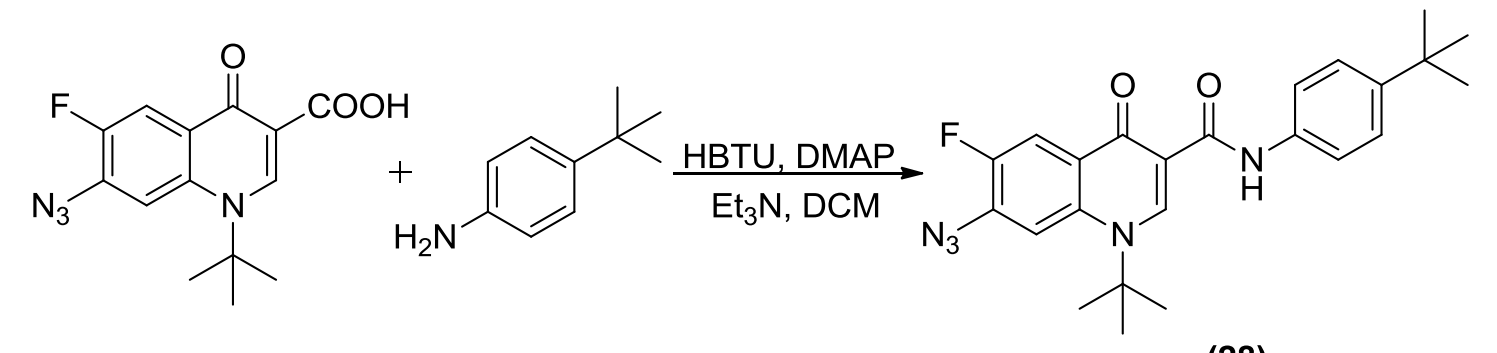

(28)

Scheme 21: Synthesis of azido photoaffinity label, compound 28

\subsubsection{Synthesis of Benzophenone Photoaffinity Label:}

Another photoaffinity label of interest is a molecule with a benzophenone derivative on the RHS. Synthesis of the benzophenone RHS amine was done over three steps (Scheme 22). The first step was the synthesis of 3-benzamidophenylbenzoate, compound $\mathbf{2 9}$, through the reaction of $m$ aminophenol with 2 eq. of benzoyl chloride in the presence of $\mathrm{Et}_{3} \mathrm{~N}$ and DMAP (Scheme 22). ${ }^{40}$ The next step was a Fries rearrangement, a rearrangement reaction of a phenyl ester to a hydroxyl aryl ketone using a Lewis acids catalyst. ${ }^{46}$ Compound 29 was mixed with 2 eq. of $\mathrm{AlCl}_{3}$ and the mixture was heated neat over a heating mantle, until melting for $15 \mathrm{~min}$. Following an acidic workup, $\mathrm{N}$-(4-benzoyl-3-hydroxyphenyl)benzamide, compound 30, was isolated as a 
brown oil that was used in the next step without further purification. The last step was amide hydrolysis, by making a $0.2 \mathrm{M}$ solution of the crude $\mathbf{3 0}$ in aq. $\mathrm{HBr}$ and the mixture was heated to $90{ }^{\circ} \mathrm{C}$ for 2 days. The benzophenone, (4-amino-2-hydroxyphenyl)phenyl)methanone (compound 31), was then isolated by column chromatography as a brown solid (Scheme 22).

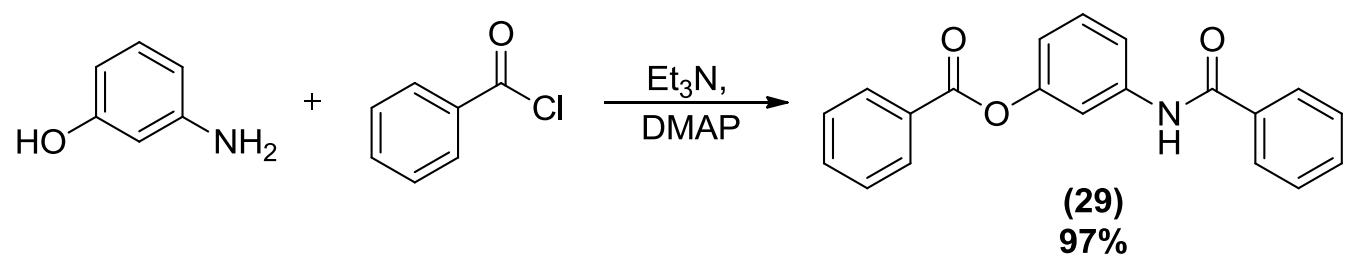

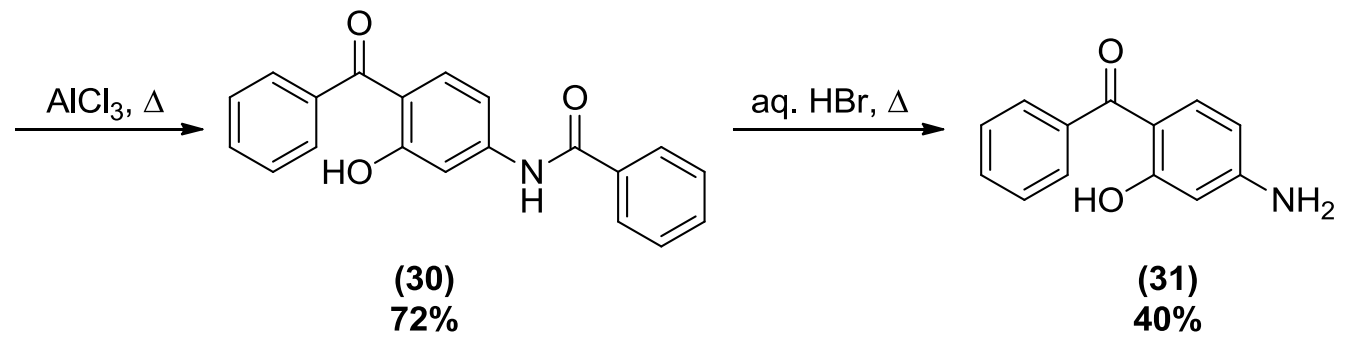

Scheme 22: Synthesis of (4-Amino-2-hydroxyphenyl)phenyl)methanone

Finally, the benzophenone RHS was coupled to the LHS analogously to compound 18 (Scheme 23). The reaction was done on a small scale $(0.234 \mathrm{mmol}$ of the carboxylic acid), using 2 eq. of the benzophenone RHS amine, 1.24 eq. of HBTU and 2.4 eq. of $\mathrm{Et}_{3} \mathrm{~N}$. By NMR analysis, the desired product is maybe present but due to the small amount of collected material (10 $\mathrm{mg})$, the purification was not attempted. Retrying the reaction on a bigger scale can help facilitate the purification process and isolate useful amounts of the desired product. 
<smiles>O=C(O)c1c[nH]c2ccccc2c1=O</smiles><smiles>Nc1ccc(C(=O)c2ccccc2)c(O)c1</smiles><smiles>O=C(c1ccccc1)c1ccc(NC(=O)c2c[nH]c3ccccc3c2=O)cc1O</smiles>

(32)

Scheme 23: Synthesis of benzophenone photoaffinity label, compound 32

\subsubsection{Synthesis of Trifluoromethyl Diazirine Photoaffinity Label:}

Trifluoromethyl diazirine is another example of photoaffinity labels. We tried different approaches towards the synthesis of a diazirine label on the RHS.

\subsubsection{First approach: Starting from $m$-aminophenol:}

The first approach involved treatment of $m$-aminophenol with a trifluoroacetylating agent, trifluoroacetic anhydride (TFAA), followed by Fries rearrangement, and then through several steps the trifluoroketone can be converted into trifluoromethyl diazirine (Scheme 24).

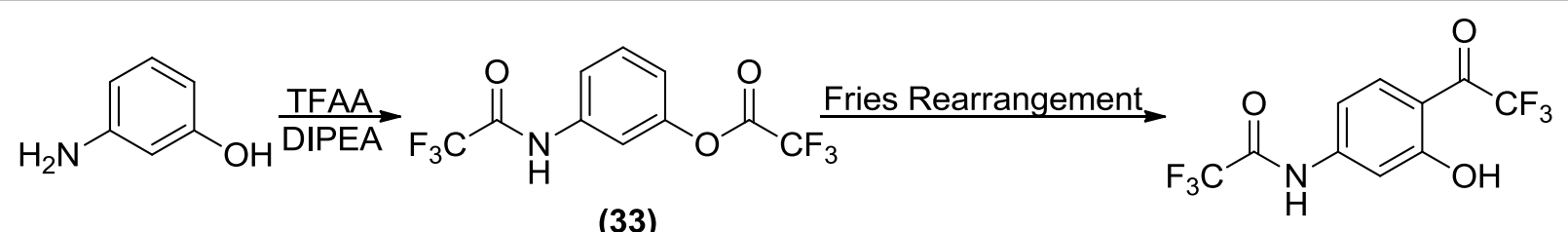

(33)<smiles>Cc1ccc(C2(C(F)(F)F)N=N2)c(O)c1</smiles>

Scheme 24: Towards the synthesis of trifluoromethyl diazirine starting from $m$ aminophenol 
To make compound 33, a suspension of $m$-aminophenol in DCM was treated with 3 eq. of Hunig's base, $N, N$-diisopropylethylamine (DIPEA). TFAA was added dropwise and the mixture was stirred at room temperature overnight. During the addition of TFAA, fuming was observed. After checking by TLC, a new spot was formed. The reaction mixture was diluted with EtOAc and extracted sequentially with $1 \mathrm{M} \mathrm{HCl}, \mathrm{NaHCO}_{3}$ and brine. The combined organic layers were dried over $\mathrm{MgSO}_{4}$ and evaporated under reduced pressure. By NMR analysis of the crude reaction mixture, the product was maybe present along with a lot of Hunig's base and some other impurities. To remove excess Hunig's base, several aqueous extractions were performed. The crude reaction mixture was checked by NMR to find that the product had decomposed. Compound $\mathbf{3 3}$ is prone to hydrolysis and it lost one of the $-\mathrm{COCF}_{3}$ groups. The same reaction was repeated with different ways of purification, to decrease contact with water, such as; column chromatography and vacuum distillation, but with the same result.

In order to avoid the hydrolysis of compound $\mathbf{3 3}$, we thought of carrying the crude $\mathbf{3 3}$ directly to the next step without purification. This method involves the treatment of an ice cold suspension of $m$-aminophenol in DCM with 3 eq. of Hunig's base. 2.9 Eq. of TFAA were diluted with an equivalent amount of DCM and the resulting solution was added dropwise to the previous mixture over $0.5 \mathrm{hr}$. to avoid fuming. After stirring at room temperature overnight, the reaction mixture was quenched with $\mathrm{NH}_{4} \mathrm{Cl}$ and extracted with DCM. By NMR, the intermediate 33 was present. For the following Fries rearrangement step, the resulting oil was mixed with 1.1 eq. of $\mathrm{AlCl}_{3}$, under inert atmosphere, and the mixture was heated gradually to $130{ }^{\circ} \mathrm{C}$ using an oil bath. ${ }^{41}$ The temperature was maintained for $2 \mathrm{hr}$. and then the reaction mixture was left at $60{ }^{\circ} \mathrm{C}$ overnight. After acidic workup and NMR analysis of the crude mixture, it was found that the Fries rearrangement reaction did not work and compound $\mathbf{3 3}$ was recovered. One pot synthesis was also attempted. The procedure entails heating a solution of $m$ - 
aminophenol in 9 eq. of TFAA to reflux for $3 \mathrm{hr}$., followed by the addition of 2 eq. of $\mathrm{AlCl}_{3}$. The reaction was heated over a heating mantle for $10 \mathrm{~min}$. After cooling to room temperature, the reaction mixture was poured into an excess of $2 \mathrm{~N} \mathrm{HCl}$ and extracted with DCM. The reaction did not work as desired where a decomposition product was isolated (Figure 16).<smiles>O=C(Nc1cccc(O)c1)C(F)(F)F</smiles>

Figure 16: Main product of trifuoroacetylation-Fries reaction

\subsubsection{Second approach: Starting from $N$-(3-hydroxyphenyl)benzamide:}

Another approach was also attempted starting from $N$-(3-hydroxyphenyl)benzamide, compound 34. A benzoyl group is attached to the nitrogen to decrease its nucleophilicity and favor the esterification reaction using TFAA. Compound $\mathbf{3 4}$ was made by ester hydrolysis of 29 using aq. $\mathrm{NaOH}$ and the resulting precipitate was purified using column chromatography (Scheme 25).
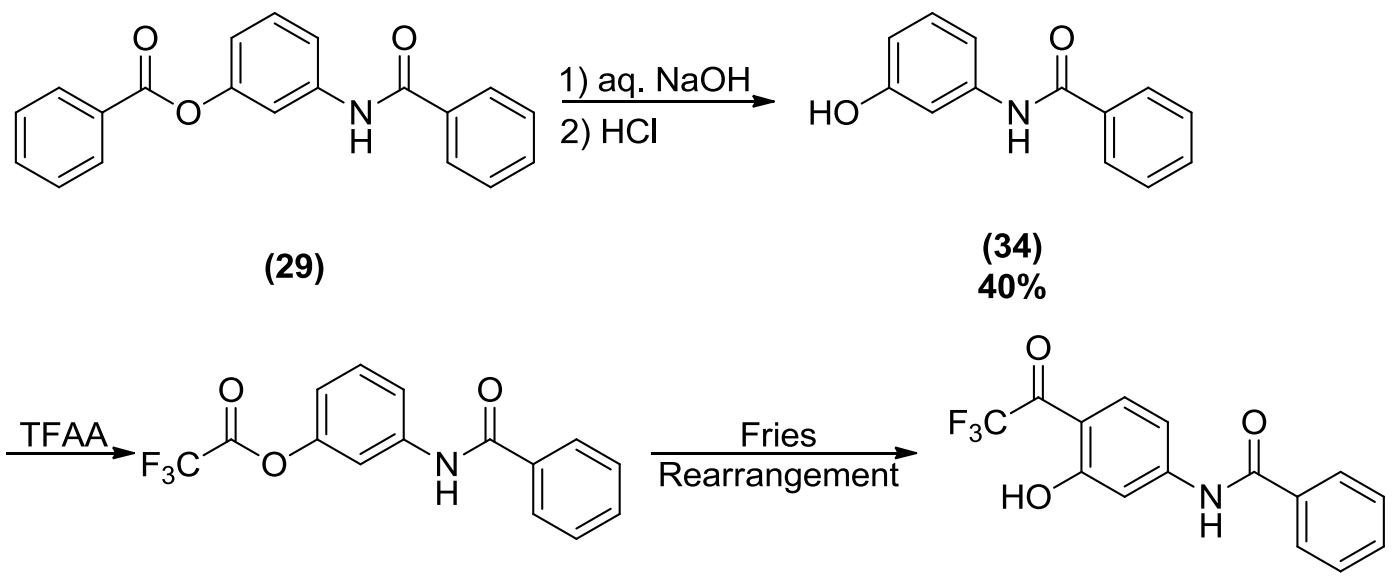

Scheme 25: Towards the synthesis of trifluoromethyl diazirine starting from $N-(3-$ hydroxyphenyl)benzamide 
The following esterification and Fries rearrangement reactions were done in a one pot. Comound 34 was dissolved in 9 eq. of TFAA and the reaction mixture was heated to reflux for 5 hrs. 2 eq. of $\mathrm{AlCl}_{3}$ were then added and the heating was continued for $15 \mathrm{~min}$. over a heating mantle. After cooling to room temperature, $5 \mathrm{~N} \mathrm{HCl}$ was added and the reaction mixture was extracted with EtOAc. The organic layer was then extracted sequentially with $\mathrm{NaOH}$ and brine. By TLC, a new spot appeared. The crude reaction mixture was purified by column chromatography. The desired product was isolated but impure and needs further characterization.

In conclusion, different approaches were attempted for the synthesis of the trifluoromethyl diazirine photoaffinity label but with no positive results. Better, more efficient conditions can be attempted to make the desired label by a future student.

\subsubsection{Synthesis of Tritium Radio Label:}

Making a radiolabel, e.g. tritiation, of VX770 is a good way for tracking the drug and the identification of the exact site of interaction. The pathway we followed for tritium labeling is halogenation of the LHS, followed by lithium halogen exchange and then quenching with a silyl group. The silyl derivative can then serve as shelf-stable, non-radioactive precursor to the tritiated compound, which should be obtainable through a straightforward proto (or tritio) desilylation, i.e. treating the silyl compound with fluoride dissolved in tritiated water.

Synthesis of bromo-LHS was performed analogously as the quinolinone LHS, by heating a solution of 4-bromoaniline and DEEMM in EtOH to reflux, followed by cyclization and ester hydrolysis (Scheme 26). 


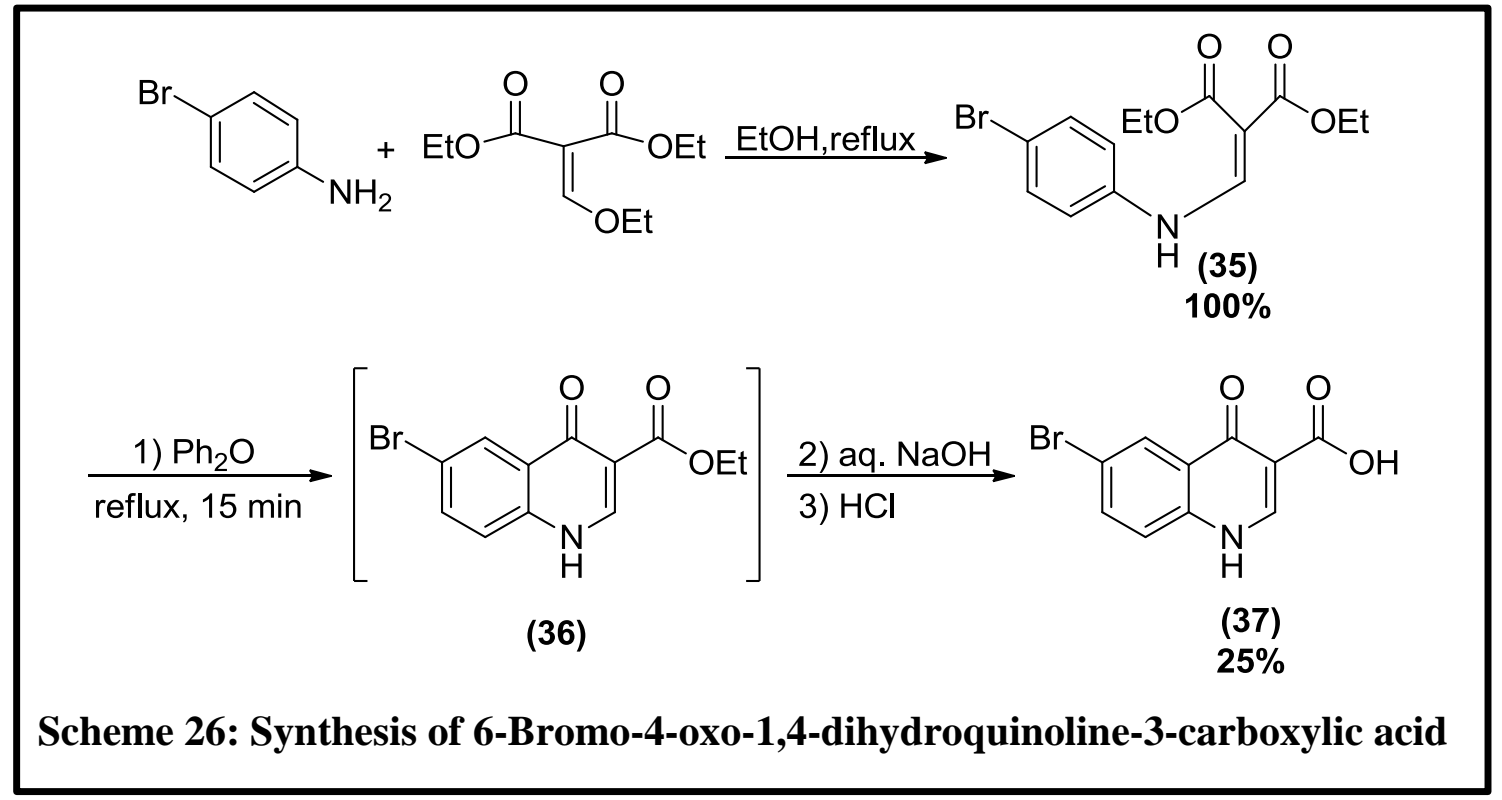

The bromo LHS (37) was carried to the next step, lithium halogen exchange. A suspension of compound 37 in dry THF was cooled to $-87^{\circ} \mathrm{C}$ and treated with 5 eq. of $2.5 \mathrm{M} n$-BuLi. The reaction mixture was warmed to $\sim-40{ }^{\circ} \mathrm{C}$ for $0.5 \mathrm{hr}$. and then recooled back to $-87^{\circ} \mathrm{C}$ where 10 eq. of trimethylsilyl chloride (TMSCl) were added. Stirring was continued at room temperature overnight. Following an acidic workup, a precipitate was formed. By NMR analysis, the reaction did not work and the starting material was totally recovered.

To allow the lithium halogen exchange reaction, an alternative method was pursued using $\mathrm{Et}_{3} \mathrm{~N}$ to increase the reactivity of the starting material. 3 eq. of $\mathrm{Et}_{3} \mathrm{~N}$ were added to a suspension of 37 in dry THF at $-87^{\circ} \mathrm{C}$ where the suspension turned clear. To the resulting solution, an excess of TMSCl (10 eq.) were added and a milky suspension was formed. The resulting suspension was then treated with 5 eq. of $2.5 \mathrm{M} \mathrm{n}$-BuLi and the mixture was warmed to room temperature and stirring was continued overnight. The reaction mixture was poured onto EtOAc, acidified with 2 $\mathrm{N} \mathrm{HCl}$ and the formed precipitate was collected. Addition of a base, $\mathrm{Et}_{3} \mathrm{~N}$, to the reaction mixture did not succeed to bring about the desired silyl product where the starting material was recovered. 
Different conditions can be attempted in the future in order to successfully make VX770 radio label. 


\section{Experimental}

\section{$\underline{\text { General Considerations }}$}

All reagents unless otherwise stated are purchased from Sigma Aldrich. Thin layer chromatography (TLC) was carried out on silica gel 60 F254 aluminum backed plates, supplied by EMD chemicals, eluting with the solvent system indicated and visualizing using UV light. Column chromatography was performed using Silicycle SiliaFlash P60, 40-63 $\mu \mathrm{m}$ silica gel, eluting with the solvent system indicated below. Melting point determination was done in open air and was not corrected. ${ }^{1} \mathrm{H},{ }^{13} \mathrm{C},{ }^{19} \mathrm{~F}-\mathrm{NMR}$ spectra were recorded on a $400 \mathrm{MHz}$ Bruker Avance II-400 Spectrometer (Ryerson University), unless otherwise reported all ${ }^{13} \mathrm{C}$ and ${ }^{19} \mathrm{~F}$ were proton decoupled. High-performance liquid chromatography (HPLC) analysis was performed with an agilent Zorbax Rx-C8 4-6 $\mathrm{mm} \times 150 \mathrm{~mm}$ column with a binary gradient of $90 \%$ water to $100 \%$ acetonitrile over one $\mathrm{hr}$.

\section{Diethyl-2-((phenylamino)methylene)malonate (1):}

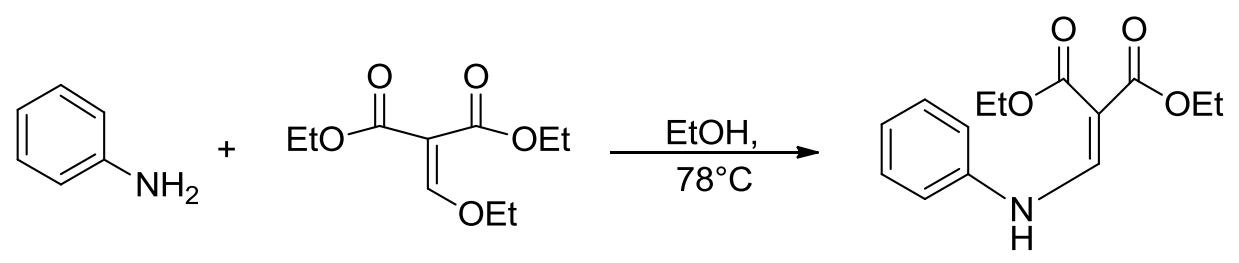

(1)

$100 \%$

To a solution of aniline (45 mmol, $4.1 \mathrm{~mL})$ in $45 \mathrm{~mL}$ of ethanol, diethyl-2(ethoxymethylene)malonate ( $45 \mathrm{mmol}, 9.1 \mathrm{~mL}$ ) was added and the mixture was heated to reflux $\left(78{ }^{\circ} \mathrm{C}\right)$ overnight. After cooling to room temperature, the mixture was dried by rotary evaporation under reduced pressure then left under vacuum for $4 \mathrm{hrs}$ to afford the desired compound quantitatively as a yellowish brown solid $(11.9 \mathrm{~g}),\left(\mathrm{mp}=51-52{ }^{\circ} \mathrm{C}\right.$, lit. $\mathrm{mp}=54-55$ $\left.{ }^{\circ} \mathrm{C}\right) .{ }^{47} \mathrm{R}_{\mathrm{f}}=0.49\left(\mathrm{SiO}_{2}, 50 \%\right.$ EtOAc:Hexanes); ${ }^{1} \mathrm{H}-\mathrm{NMR}\left(400 \mathrm{MHz}, \mathrm{CDCl}_{3}\right), \delta 10.99(\mathrm{~d}, J=$ 
$13.5 \mathrm{~Hz}, 1 \mathrm{H}), 8.52(\mathrm{~d}, J=13.5 \mathrm{~Hz}, 1 \mathrm{H}), 7.40-7.32(\mathrm{~m}, 2 \mathrm{H}), 7.18-7.09(\mathrm{~m}, 3 \mathrm{H}), 4.30(\mathrm{q}, J=4$ $\mathrm{Hz}, 2 \mathrm{H}), 4.24(\mathrm{q}, J=4 \mathrm{~Hz}, 2 \mathrm{H}), 1.37(\mathrm{t}, J=4 \mathrm{~Hz}, 3 \mathrm{H}), 1.32(\mathrm{t}, J=4 \mathrm{~Hz}, 3 \mathrm{H}),{ }^{13} \mathrm{C}-\mathrm{NMR}(100$ $\left.\mathrm{MHz}, \mathrm{CDCl}_{3}\right), \delta 169.04,165.71,151.91,139.24,129.82,124.90,117.15,93.50,60.37,60.07$, $14.42,14.30$.

Diethyl-2-(((4-methoxyphenyl)amino)methylene)malonate (2):<smiles>CCOC(=O)C(=CNc1ccc(OCC(CC)C(=O)OCC)cc1)C(=O)OCC</smiles>

p-Anisidine (10 mmol, $1.23 \mathrm{~g})$ was dissolved in $15 \mathrm{~mL}$ of ethanol followed by the addition of diethyl-2-(ethoxymethylene)malonate $(10 \mathrm{mmol}, 2 \mathrm{~mL})$ and then the mixture was heated to reflux $\left(78{ }^{\circ} \mathrm{C}\right)$ overnight. After cooling to room temperature, the mixture was dried by rotary evaporation under reduced pressure. The mixture was purified by column chromatography (ethyl acetate) to afford the title compound in $96 \%$ yield $(2.8 \mathrm{~g})$ as yellow oil. $\mathrm{R}_{\mathrm{f}}=0.45\left(\mathrm{SiO}_{2}, 50 \%\right.$ EtOAc:Hexanes); ${ }^{1} \mathrm{H}-\mathrm{NMR}\left(400 \mathrm{MHz}, \mathrm{CDCl}_{3}\right), \delta 10.98(\mathrm{~d}, J=14 \mathrm{~Hz}, 1 \mathrm{H}), 8.43$ (d, $J=14 \mathrm{~Hz}$, $1 \mathrm{H}), 7.07(\mathrm{~d}, J=9 \mathrm{~Hz}, 2 \mathrm{H}), 6.90(\mathrm{~d}, J=9 \mathrm{~Hz}, 2 \mathrm{H}), 4.29(\mathrm{q}, J=8 \mathrm{~Hz}, 2 \mathrm{H}), 4.23(\mathrm{q}, J=7.2 \mathrm{~Hz}$, 2H), $3.80(\mathrm{~s}, 3 \mathrm{H}), 1.37(\mathrm{t}, J=7.2 \mathrm{~Hz}, 3 \mathrm{H}), 1.31(\mathrm{t}, J=7.2 \mathrm{~Hz}, 3 \mathrm{H}),{ }^{13} \mathrm{C}-\mathrm{NMR}(100 \mathrm{MHz}$, $\left.\mathrm{CDCl}_{3}\right), \delta 169.10,165.79,157.13,152.53,132.70,118.72,114.93,92.39,60.15,59.87,55.45$, 14.38, 14.27 . 
Diethyl-2-((N-(4-methoxyphenyl)acetamido)methylene)malonate (3):

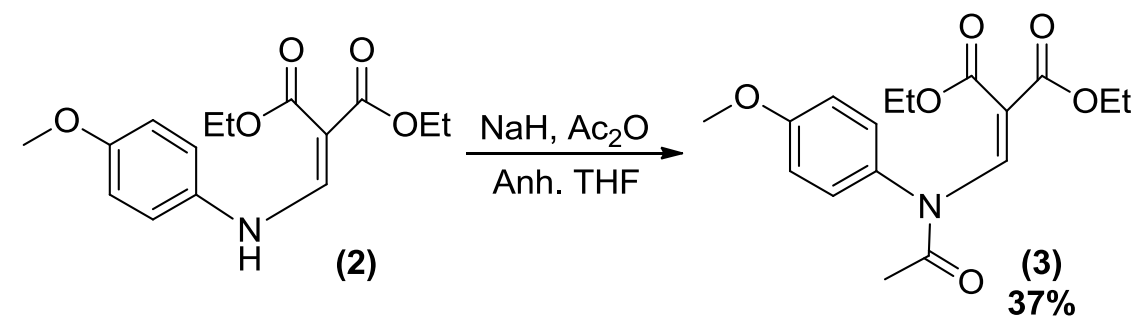

Diethyl-2-(((4-methoxyphenyl)amino)methylene)malonate (6 mmol, $1.76 \mathrm{~g})$ was dissolved in 20 $\mathrm{mL}$ of anhydrous THF. The mixture was cooled in ice bath, and then sodium hydride (4 eq., 960 mg) was added slowly. After the reaction mixture stopped bubbling, acetic anhydride (12 mmol, $1.1 \mathrm{~mL}$ ) was added and then the mixture was stirred at room temperature for $48 \mathrm{hrs}$. The mixture was quenched with saturated ammonium chloride very carefully, to avoid overflowing of the reaction mixture, then extracted with ethyl acetate $(\times 3)$. The combined organic layers were dried over magnesium sulfate and concentrated under vacuum. The desired compound was separated by column chromatography (30\% ethyl acetate - hexanes) as yellow crystalline solid (378 mg, $37 \%),\left(\mathrm{mp}=72-75{ }^{\circ} \mathrm{C}\right) . \mathrm{R}_{\mathrm{f}}=0.39\left(\mathrm{SiO}_{2}, 50 \%\right.$ EtOAc:Hexanes $) ;{ }^{1} \mathrm{H}-\mathrm{NMR}\left(400 \mathrm{MHz}, \mathrm{CDCl}_{3}\right), \delta$ 8.57 (s, 1H), 7.15-7.10 (m, 2H), 6.94-6.89 (m, 2H), $4.20(\mathrm{q}, J=7.2 \mathrm{~Hz}, 2 \mathrm{H}), 3.84(\mathrm{~s}, 3 \mathrm{H}), 3.54$ (q, $J=7.2 \mathrm{~Hz}, 2 \mathrm{H}), 1.94(\mathrm{~s}, 3 \mathrm{H}), 1.25(\mathrm{t}, J=7.2 \mathrm{~Hz}, 3 \mathrm{H}), 1.07(\mathrm{t}, J=7.2 \mathrm{~Hz}, 3 \mathrm{H}),{ }^{13} \mathrm{C}-\mathrm{NMR}$ $\left(100 \mathrm{MHz}, \mathrm{CDCl}_{3}\right), \delta 170.91,165.15,164.54,160.16,137.71,130.55,130.29,114.47,109.50$ 61.11, 61.02, 55.57, 23.01, 14.15, 13.60. 
4-Oxo-1,4-dihydroquinoline-3-carboxylic acid (5):

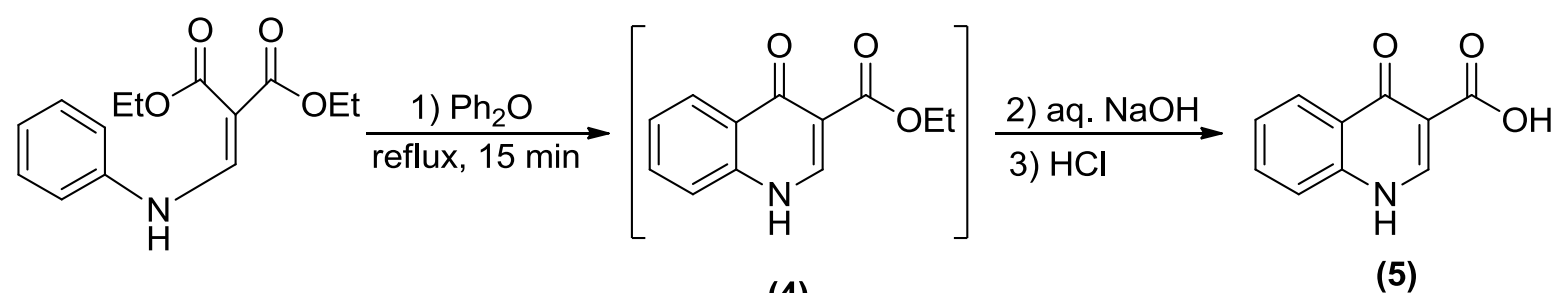

(4)

$52 \%$

Diethyl-2-((phenylamino)methylene)malonate $(14.3 \mathrm{mmol}, 3.76 \mathrm{~g})$ was dissolved in $14.3 \mathrm{~mL}$ of diphenyl ether (1 M solution). Over a heating mantle, the solution was heated to reflux for 15 minutes to afford ethyl-4-oxo-1,4-dihydroquinoline-3-carboxylate (4). The reaction mixture was cooled to room temperature and then aqueous sodium hydroxide solution $(2 \mathrm{~N}, 31 \mathrm{~mL})$ was added. The mixture was heated to reflux overnight. After cooling to room temperature, the mixture was extracted with ethyl acetate $(\times 3)$, and then the aqueous layer was acidified to $\mathrm{pH} 4$ with $2 \mathrm{~N} \mathrm{HCl}$. The resulting precipitate was collected via filtration, washed with water and dried under vacuum to afford the title compound as a pale white solid in a $52 \%$ yield $(1.4 \mathrm{~g}),(\mathrm{mp}=$ 285-286 ${ }^{\circ} \mathrm{C}$, lit. $\left.\mathrm{mp}=256-265{ }^{\circ} \mathrm{C}\right) .{ }^{48} \mathrm{R}_{\mathrm{f}}=0.14\left(\mathrm{SiO}_{2}, 50 \%\right.$ DCM:Ether $) ;{ }^{1} \mathrm{H}-\mathrm{NMR}(400 \mathrm{MHz}$, $\left.\left(\mathrm{CD}_{3}\right)_{2} \mathrm{SO}\right), \delta 15.37$ (s, 1H), 13.42 (br. s, $\left.1 \mathrm{H}\right), 8.89$ (s, 1H), 8.30 (d, $\left.J=7.6 \mathrm{~Hz}, 1 \mathrm{H}\right), 7.90(\mathrm{dd}, J=$ $7.8 \mathrm{~Hz}, J=7.8 \mathrm{~Hz}, 1 \mathrm{H}), 7.82(\mathrm{~d}, J=8.4 \mathrm{~Hz}, 1 \mathrm{H}), 7.61(\mathrm{dd}, J=7.6 \mathrm{~Hz}, J=7.6 \mathrm{~Hz}, 1 \mathrm{H}),{ }^{13} \mathrm{C}-\mathrm{NMR}$ $\left(100 \mathrm{MHz},\left(\mathrm{CD}_{3}\right)_{2} \mathrm{SO}\right), \delta 178.78,166.89,145.73,139.99,134.41,126.68,125.51,124.85$, 120.19, 108.02 . 


\section{5-(((4-Methoxyphenyl)amino)methylene)-2,2-dimethyl-1,3dioxane-4,6-dione (7):}

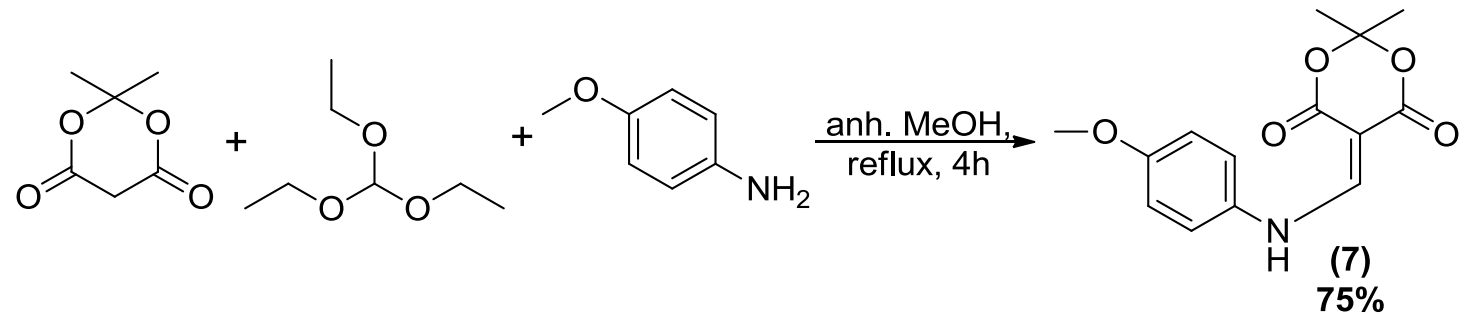

p-Anisidine (10.6 mmol, $1.3 \mathrm{~g}$ ) was added to a suspension of Meldrum's acid (12.7 mmol, 1.83 $\mathrm{g})$ in $10 \mathrm{~mL}$ of anhydrous of methanol. Triethyl orthoformate $(9.6 \mathrm{mmol}, 1.6 \mathrm{~mL})$ was added and the mixture was refluxed for $4 \mathrm{hrs}$. After cooling to room temperature, a white precipitate was formed and was isolated via vacuum filtration. The precipitate was washed with anhydrous methanol and dried under vacuum to give the desired compound in a $75 \%$ yield $(1.98 \mathrm{~g}),(\mathrm{mp}=$ $\left.160-161{ }^{\circ} \mathrm{C}\right) . \mathrm{R}_{\mathrm{f}}=0.31\left(\mathrm{SiO}_{2}, 50 \%\right.$ EtOAc:Hexanes $) ;{ }^{1} \mathrm{H}-\mathrm{NMR}\left(400 \mathrm{MHz}, \mathrm{CDCl}_{3}\right), \delta 11.22(\mathrm{~d}, J$ $=14 \mathrm{~Hz}, 1 \mathrm{H}), 8.53(\mathrm{~d}, J=14 \mathrm{~Hz}, 1 \mathrm{H}), 7.21-7.14(\mathrm{~m}, 2 \mathrm{H}), 6.97-6.91(\mathrm{~m}, 2 \mathrm{H}), 3.82(\mathrm{~s}, 3 \mathrm{H}), 1.74$ $(\mathrm{s}, 6 \mathrm{H}),{ }^{13} \mathrm{C}-\mathrm{NMR}\left(100 \mathrm{MHz}, \mathrm{CDCl}_{3}\right), \delta 165.67,163.69,158.52,152.71,131.14,119.62,115.23$, 105.07, 86.47, 55.61, 27.00.

\section{Methyl anthranilate (8):}<smiles>COCCOCCOc1c(N)cccc1C(=O)OC</smiles>

(8)

$100 \%$

An excess of potassium tert-butoxide $(14.4 \mathrm{mmol}, 1.62 \mathrm{~g})$ was added to a suspension of isatoic anhydride (12 mmol, $10 \mathrm{~g})$ in $120 \mathrm{~mL}$ of methanol. The mixture was heated to reflux overnight. After cooling to room temperature, half of the solvent was evaporated under reduced pressure and the other half was partitioned between water and ethyl acetate. The organic layer was dried over magnesium sulfate and concentrated under vacuum to yield the desired product as a brown 
oil quantitavely (1.8 g). $\mathrm{R}_{\mathrm{f}}=0.55\left(\mathrm{SiO}_{2}, 50 \%\right.$ EtOAc:Hexanes); ${ }^{1} \mathrm{H}-\mathrm{NMR}\left(400 \mathrm{MHz}, \mathrm{CDCl}_{3}\right), \delta$ $7.88(\mathrm{dd}, J=1.6 \mathrm{~Hz}, J=8.4 \mathrm{~Hz}, 1 \mathrm{H}), 7.26(\mathrm{dt}, J=1.6 \mathrm{~Hz}, J=8.4 \mathrm{~Hz}, 1 \mathrm{H}), 6.68-6.62(\mathrm{~m}, 2 \mathrm{H})$, 5.75 (br. s, 2H), 3.87 (s, 3H), ${ }^{13} \mathrm{C}-\mathrm{NMR}\left(100 \mathrm{MHz}, \mathrm{CDCl}_{3}\right), \delta 168.63,150.57,134.12,131.23$, $116.73,116.21,110.68,51.50$.

\section{Monoethyl malonate (3-ethoxy-3-oxopropanoic acid) (9):}

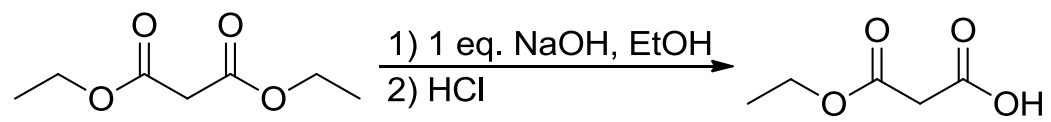

(9)

Diethyl malonate (250 mmol, $40 \mathrm{~g}$ ) was dissolved in $160 \mathrm{~mL}$ of ethanol. While stirring at room temperature, a mixture of sodium hydroxide $(250 \mathrm{mmol}, 10.3 \mathrm{~g})$ and ethanol $(150 \mathrm{~mL})$ was added dropwise over $1 \mathrm{hr}$. The mixture was then heated to reflux for $1 \mathrm{hr} .^{33}$ The solvent was removed by rotary evaporation under reduced pressure and a white solid was obtained. The white solid was dissolved in $100 \mathrm{~mL}$ of distilled water and the solution was acidified with concentrated $\mathrm{HCl}$ to maintain $\mathrm{pH}$ at $3{ }^{33}$ The solution was extracted with ethyl acetate $(250 \mathrm{~mL} \times 5)$. The organic layer was dried over anhydrous $\mathrm{Na}_{2} \mathrm{SO}_{4}$ and then concentrated under vacuum to give a light yellow liquid in a $60 \%$ yield $(17 \mathrm{~mL}) . \mathrm{R}_{\mathrm{f}}=0.64\left(\mathrm{SiO}_{2}, 50 \%\right.$ EtOAc:Hexanes $) ;{ }^{1} \mathrm{H}-\mathrm{NMR}$ $\left(400 \mathrm{MHz}, \mathrm{CDCl}_{3}\right), \delta 10.78(\mathrm{~s}, 1 \mathrm{H}), 3.99(\mathrm{q}, J=7 \mathrm{~Hz}, 2 \mathrm{H}), 3.24(\mathrm{~s}, 2 \mathrm{H}), 1.05(\mathrm{t}, J=7 \mathrm{~Hz}, 3 \mathrm{H})$, ${ }^{13} \mathrm{C}-\mathrm{NMR}\left(100 \mathrm{MHz}, \mathrm{CDCl}_{3}\right), \delta 170.86,166.97,61.64,40.68,13.51$. 


\section{2-Nitrobenzoyl chloride (10):}

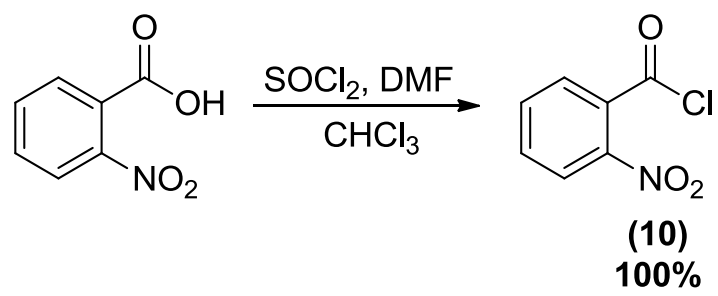

2-Nitrobenzoic acid (6 mmol, $1.003 \mathrm{~g}$ ) was mixed with $5 \mathrm{~mL}$ of chloroform. To the formed suspension, thionyl chloride $(10 \mathrm{mmol}, 0.72 \mathrm{~mL})$ was added dropwise over 10 minutes followed by the addition of 2 drops of dry DMF. The mixture was heated to reflux for 5 hrs. After cooling to room temperature, the solvent was removed by rotary evaporation. The resulting oil was mixed with more chloroform and reevaporated to give the title compound as light brown oil quantitatively $(1.1 \mathrm{~g})$ which was used without further purification. $\mathrm{R}_{\mathrm{f}}=0.09\left(\mathrm{SiO}_{2}, 50 \%\right.$ EtOAc:Hexanes); ${ }^{1} \mathrm{H}-\mathrm{NMR}\left(400 \mathrm{MHz}, \mathrm{CDCl}_{3}\right), \delta 8.09$ (d, $\left.J=8 \mathrm{~Hz}, 1 \mathrm{H}\right), 7.79$ (d, $J=7.4 \mathrm{~Hz}$, 1H), 7.77-7.71 (m, 2H).

Ethyl-3-(2-nitrophenyl)-3-oxopropanoate (11):<smiles>CCN(CC)C(C)(C)N=NC(=O)c1ccccc1[N+](=O)[O-]</smiles>

(9)

(10)<smiles>CCOC(=O)CC(=O)c1ccccc1[N+](=O)[O-]</smiles>

(11)

A stirred solution of monoethyl malonate $(21 \mathrm{mmol}, 2.5 \mathrm{~mL})$ in anhydrous acetonitrile $(33.5 \mathrm{~mL})$ under argon was cooled to $0^{\circ} \mathrm{C}$. To this solution was added triethylamine $(41.2 \mathrm{mmol}, 5.74 \mathrm{~mL})$ followed by magnesium chloride $(25.7 \mathrm{mmol}, 2.45 \mathrm{~g})$, and stirring was continued at room temperature for $2.5 \mathrm{hrs}^{34}$ The resultant solution was recooled to $0{ }^{\circ} \mathrm{C}$ and 2 -nitrobenzoyl chloride (10.22 mmol, $1.35 \mathrm{~mL}$ ) was added dropwise over 15 minutes followed by the addition of triethylamine $(2 \mathrm{mmol}, 0.28 \mathrm{~mL})$. The mixture was stirred at room temperature overnight and 
then concentrated under reduced pressure to remove acetonitrile. Toluene $(17 \mathrm{~mL})$ was added and the mixture was concentrated under vacuum. More toluene $(17 \mathrm{~mL})$ was added and the mixture and cooled in an ice bath. Aqueous $\mathrm{HCl}(13 \%, 21 \mathrm{~mL})$ was added while the temperature was kept at $0{ }^{\circ} \mathrm{C}$. The aqueous layer was separated and the organic layer washed with aqueous $\mathrm{HCl}(12 \%, 20 \mathrm{~mL})$, followed by water $(\times 2) .{ }^{34}$ The organic layer was dried over $\mathrm{MgSO}_{4}$ and evaporated affording the desired crude product as a reddish orange oil (2.34 g, 97\%). The crude product was a mixture of keto and enol tautomers in a ratio of $1.33: 1$, respectively, $R_{f}=0.47$ $\left(\mathrm{SiO}_{2}, 50 \%\right.$ EtOAc:Hexanes); ${ }^{1} \mathrm{H}-\mathrm{NMR}$ (keto form, $400 \mathrm{MHz}, \mathrm{CDCl}_{3}$ ), $\delta 8.09$ (d, $J=9.6 \mathrm{~Hz}$, $1 \mathrm{H}), 7.72(\mathrm{t}, J=7.6 \mathrm{~Hz}, 1 \mathrm{H}), 7.65-7.56(\mathrm{~m}, 1 \mathrm{H}), 7.48(\mathrm{~d}, J=7.6 \mathrm{~Hz}, 1 \mathrm{H}), 4.10(\mathrm{q}, J=6.8 \mathrm{~Hz}$, 2H), $3.83(\mathrm{~s}, 2 \mathrm{H}), 1.17(\mathrm{t}, J=7.2 \mathrm{~Hz}, 3 \mathrm{H})$, (enol form, $\left.400 \mathrm{MHz}, \mathrm{CDCl}_{3}\right), \delta 14.02(\mathrm{~s}, 1 \mathrm{H}), 8.15-$ $8.07(\mathrm{~m}, 3 \mathrm{H}), 7.64-7.56(\mathrm{~m}, 1 \mathrm{H}), 7.37(\mathrm{~d}, J=7.2 \mathrm{~Hz}, 1 \mathrm{H}), 4.32(\mathrm{q}, J=7.2 \mathrm{~Hz}, 2 \mathrm{H}), 0.82(\mathrm{t}, J=$ 7.2 Hz, 3H).

\section{Ethyl-3-(dimethylamino)-2-(2-nitrobenoyl)acrylate (12):}

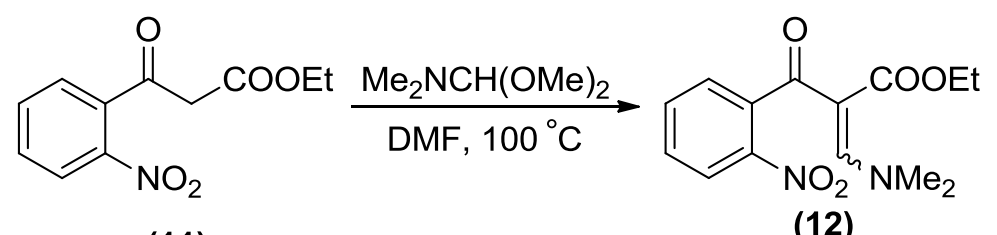

(11)

(12)

$72 \%$

A $50 \mathrm{~mL}$ Schlenk flask, equipped with a reflux condenser and an argon inlet, was charged with ethyl-3-(2-nitrophenyl)-3-oxopropanoate (16.9 mmol, $4.03 \mathrm{~g}$ ) and $20 \mathrm{~mL}$ of anhydrous DMF. The resulting solution was heated to $100{ }^{\circ} \mathrm{C}$ and $N, N$-dimethylformamide dimethyl acetal (16.9 mmol, $2.2 \mathrm{~mL}$ ) was added and the temperature was kept at $100{ }^{\circ} \mathrm{C}$ for $1 \mathrm{hr} .{ }^{32}$ The crude reaction mixture was quenched with ice cold water, stirred for 5 minutes and extracted with ether $(\times 3)$. The aqueous layer was saturated with brine and re-extracted with ether. The combined ether layers were washed with brine, dried over $\mathrm{MgSO}_{4}$ and concentrated under vacuum yielding the 
product as orange yellow oil in a $72 \%$ yield $(3.6 \mathrm{~g})$. The resulting oil was used in the next step without any further purification. $\mathrm{R}_{\mathrm{f}}=0.12\left(\mathrm{SiO}_{2}, 50 \%\right.$ EtOAc:Hexanes $) ;{ }^{1} \mathrm{H}-\mathrm{NMR}(400 \mathrm{MHz}$, $\left.\mathrm{CDCl}_{3}\right), \delta 8.03(\mathrm{~d}, J=8.4 \mathrm{~Hz}, 1 \mathrm{H}), 7.98(\mathrm{~s}, 1 \mathrm{H}), 7.62-7.57(\mathrm{~m}, 1 \mathrm{H}), 7.48-7.43(\mathrm{~m}, 1 \mathrm{H}), 7.34(\mathrm{~d}, J$ $=7.6 \mathrm{~Hz}, 1 \mathrm{H}), 3.82(\mathrm{q}, J=8.8 \mathrm{~Hz}, 2 \mathrm{H}), 3.35(\mathrm{~s}, 3 \mathrm{H}), 3.07(\mathrm{~s}, 3 \mathrm{H}), 0.80(\mathrm{t}, J=7.2 \mathrm{~Hz}, 3 \mathrm{H})$.

\section{2,4-Di-tert-butylphenyl methyl carbonate (14):}

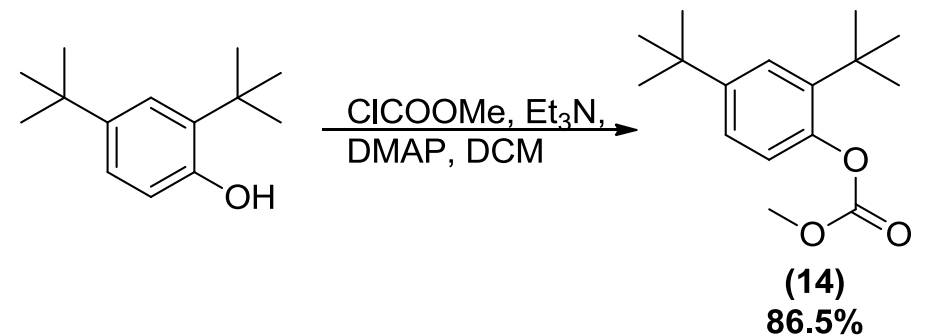

2,4-Di-tert-butylphenol ( $5 \mathrm{mmol}, 1.03 \mathrm{~g}$ ) was dissolved in $4 \mathrm{~mL}$ of dichloromethane and the solution was cooled in ice bath to $0{ }^{\circ} \mathrm{C}$. 4-Dimethylaminopyridine $(0.25 \mathrm{mmol}, 30.6 \mathrm{mg})$ and triethylamine $(10 \mathrm{mmol}, 1.4 \mathrm{~mL})$ were added and the mixture was stirred for 5 minutes. Methyl chloroformate $(7.5 \mathrm{mmol}, 0.6 \mathrm{~mL})$ was added dropwise to the mixture. ${ }^{45}$ After $0.5 \mathrm{hr}$, the mixture was allowed to warm to room temperature while stirring overnight. The resulting solution was diluted with $25 \mathrm{~mL}$ of dichloromethane and extracted sequentially with $0.1 \mathrm{M} \mathrm{HCl}, \mathrm{NaHCO}_{3}$ and brine. The organic layer was dried over $\mathrm{MgSO}_{4}$ and then concentrated under vacuum. The resulting oil was filtered through silica gel using $100 \%$ ethyl acetate providing the desired ester as a yellow oil in $86.5 \%$ yield $(1.14 \mathrm{~g}) . \mathrm{R}_{\mathrm{f}}=0.61\left(\mathrm{SiO}_{2}, 50 \%\right.$ EtOAc:Hexanes $) ;{ }^{1} \mathrm{H}-\mathrm{NMR}(400$ $\left.\mathrm{MHz}, \mathrm{CDCl}_{3}\right), \delta 7.39(\mathrm{~d}, J=2.5 \mathrm{~Hz}, 1 \mathrm{H}), 7.24(\mathrm{dd}, J=2.5 \mathrm{~Hz}, J=8.5 \mathrm{~Hz}, 1 \mathrm{H}), 7.00(\mathrm{~d}, J=$ $8.5 \mathrm{~Hz}, 1 \mathrm{H}), 3.91(\mathrm{~s}, 3 \mathrm{H}), 1.37$ (s, 9H), $1.32(\mathrm{~s}, 9 \mathrm{H}),{ }^{13} \mathrm{C}-\mathrm{NMR}\left(100 \mathrm{MHz}, \mathrm{CDCl}_{3}\right), \delta 154.65$, $148.43,147.51,139.99,124.06,123.98,122.74,55.26,34.79,34.71,31.53,30.31$. 


\section{2,4-Di-tert-butylphenyl pivalate (15):}

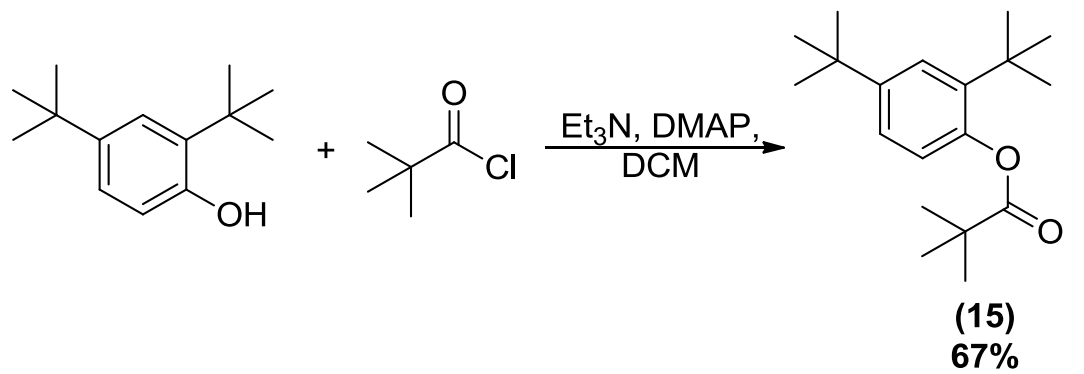

2,4-Di-tert-butylphenol (5 mmol, $1.03 \mathrm{~g}$ ) was dissolved in $4 \mathrm{~mL}$ of dichloromethane and the solution was cooled in ice bath to $0{ }^{\circ} \mathrm{C}$. 4-Dimethylaminopyridine $(0.25 \mathrm{mmol}, 30.6 \mathrm{mg})$ and triethylamine $(10 \mathrm{mmol}, 1.4 \mathrm{~mL})$ were added and the mixture was stirred for 5 minutes. Pivaloyl chloride $(7.5 \mathrm{mmol}, 0.9 \mathrm{~mL})$ was added dropwise to the mixture. After $0.5 \mathrm{hr}$, the mixture was allowed to warm to room temperature while stirring overnight. The solution was diluted with 30 $\mathrm{mL}$ of dichloromethane and extracted sequentially with $0.1 \mathrm{M} \mathrm{HCl}, \mathrm{NaHCO}_{3}$ and brine. The organic layer was dried over $\mathrm{MgSO}_{4}$ and then concentrated under vacuum to yield the desired compound as a yellow solid in 67\% yield $(966 \mathrm{mg}),\left(\mathrm{mp}=58-59{ }^{\circ} \mathrm{C}\right) . \mathrm{R}_{\mathrm{f}}=0.69\left(\mathrm{SiO}_{2}, 50 \%\right.$ EtOAc:Hexanes); ${ }^{1} \mathrm{H}-\mathrm{NMR}\left(400 \mathrm{MHz}, \mathrm{CDCl}_{3}\right), \delta 7.39(\mathrm{~d}, J=2.5 \mathrm{~Hz}, 1 \mathrm{H}), 7.21(\mathrm{dd}, J=2.5$ $\mathrm{Hz}, J=8.5 \mathrm{~Hz}, 1 \mathrm{H}), 6.79(\mathrm{~d}, J=8.5 \mathrm{~Hz}, 1 \mathrm{H}), 1.39(\mathrm{~s}, 9 \mathrm{H}), 1.35(\mathrm{~s}, 9 \mathrm{H}), 1.31(\mathrm{~s}, 9 \mathrm{H}),{ }^{13} \mathrm{C}-\mathrm{NMR}$ $\left(400 \mathrm{MHz}, \mathrm{CDCl}_{3}\right), \delta 177.23,147.82,147.71,140.05,124.01,123.88,123.10,39.19,34.75$, $34.70,31.63,30.29,27.37$. 


\section{2,4-Di-tert-butylphenyl methanesulfonate (16):}

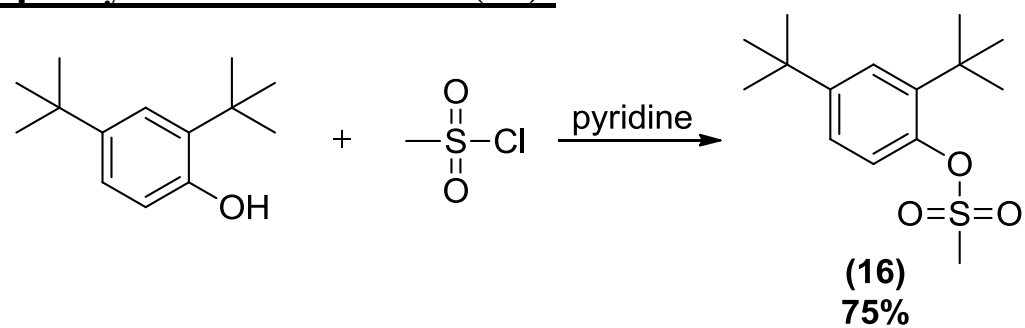

Mesyl chloride $(47.25 \mathrm{mmol}, 3.7 \mathrm{~mL})$ was added dropwise to a solution of 2,4-di-tertbutylphenol (45 mmol, $9.3 \mathrm{~g}$ ) in $6 \mathrm{~mL}$ of pyridine. ${ }^{36}$ The mixture was kept stirring in an ice bath for $1 \mathrm{hr}$, and then allowed to warm to room temperature. After stirring for $5 \mathrm{hrs}$, the mixture was poured into $180 \mathrm{~mL}$ of $5 \mathrm{M} \mathrm{HCl}$ and then extracted with $\mathrm{DCM}(\times 2)$. The organic layer was washed with $5 \mathrm{M} \mathrm{HCl}$ and water, and then dried over $\mathrm{Na}_{2} \mathrm{SO}_{4}$ and evaporated under reduced pressure. The desired product was purified by column chromatography (2\% ethyl acetatehexanes) to give a white solid in a 75\% yield $(9 \mathrm{~g}),\left(\mathrm{mp}=45-50{ }^{\circ} \mathrm{C}\right) . \mathrm{R}_{\mathrm{f}}=0.63\left(\mathrm{SiO}_{2}, 50 \%\right.$ EtOAc:Hexanes); ${ }^{1} \mathrm{H}-\mathrm{NMR}\left(400 \mathrm{MHz},\left(\mathrm{CD}_{3}\right)_{2} \mathrm{CO}\right), \delta 7.51(\mathrm{~d}, J=2.5 \mathrm{~Hz}, 1 \mathrm{H}), 7.45(\mathrm{~d}, J=9 \mathrm{~Hz}$, 1H), $7.31(\mathrm{dd}, J=2.5 \mathrm{~Hz}, \quad J=9 \mathrm{~Hz}, 1 \mathrm{H}), 3.42(\mathrm{~s}, 3 \mathrm{H}), 1.42(\mathrm{~s}, 9 \mathrm{H}), 1.32(\mathrm{~s}, 9 \mathrm{H}),{ }^{13} \mathrm{C}-\mathrm{NMR}(100$ $\left.\mathrm{MHz},\left(\mathrm{CD}_{3}\right)_{2} \mathrm{CO}\right), \delta 148.54,146.88,139.89,124.82,124.15,120.24,38.89,34.60,34.35,30.76$, 29.95 .

\section{2,4-Di-tert-butyl-6-iodophenol (17):}

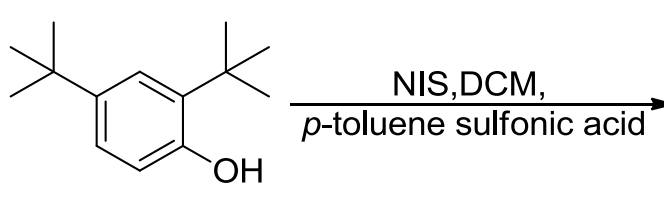<smiles>CC(C)(C)c1cc(I)c(O)c(C(C)(C)C)c1</smiles>

$(17)$ $88 \%$

To a solution of 2,4-di-tert-butylphenol (48.47 mmol, $10 \mathrm{~g})$ and $p$-toluenesulfonic acid (4.8 mmol, $913.1 \mathrm{mg}$ ) in $50 \mathrm{~mL}$ of DCM, was added $N$-iodosuccinimide $(53.27 \mathrm{mmol}, 11.98 \mathrm{~g}$ ) portionwise at room temperature. ${ }^{37}$ The reaction mixture was kept stirring at room temperature overnight. The reaction was then quenched with a $10 \%$ aqueous solution of ascorbic acid and 
extracted with DCM (× 2). The combined organic layers were dried over $\mathrm{MgSO}_{4}$ and evaporated. The desired product was separated via column chromatography (100\% hexanes) as a light yellow crystalline solid in a $88 \%$ yield $(14 \mathrm{~g}),\left(\mathrm{mp}=75-76{ }^{\circ} \mathrm{C}\right.$, lit. $\left.\mathrm{mp}=76.3-77.6{ }^{\circ} \mathrm{C}\right) .{ }^{37} \mathrm{R}_{\mathrm{f}}=0.70$ $\left(\mathrm{SiO}_{2}, 50 \%\right.$ EtOAc:Hexanes); ${ }^{1} \mathrm{H}-\mathrm{NMR}\left(400 \mathrm{MHz}, \mathrm{CDCl}_{3}\right) \delta 7.50(\mathrm{~d}, J=2.4 \mathrm{~Hz}, 1 \mathrm{H}), 7.27(\mathrm{~d}, J$ $=2 \mathrm{~Hz}, 1 \mathrm{H}), 5.34(\mathrm{~s}, 1 \mathrm{H}), 1.39(\mathrm{~s}, 9 \mathrm{H}), 1.28(\mathrm{~s}, 9 \mathrm{H}),{ }^{13} \mathrm{C}-\mathrm{NMR}\left(100 \mathrm{MHz}, \mathrm{CDCl}_{3}\right), \delta 150.35$, $144.57,136.04,132.64,124.99,89.24,35.66,34.24,31.48,29.41$.

\section{$\underline{N \text {-(4-(tert-butyl)phenyl)-4-oxo-1,4-dihydroquinoline-3-carboxamide (18): }}$}<smiles>O=C(O)c1c[nH]c2ccccc2c1=O</smiles>

(5)<smiles>CCN(CC)CC(C)(C)c1ccc(N)cc1</smiles>

$\mathrm{Et}_{3} \mathrm{~N}, \mathrm{DCM}$

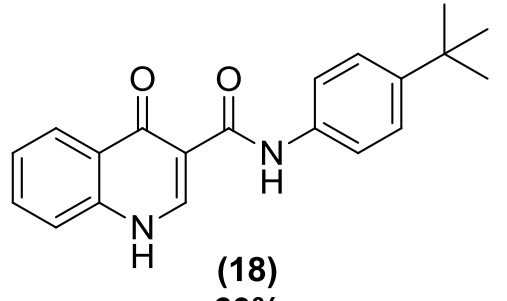

$60 \%$

To a suspension of 4-oxo-1,4-dihydroquinoline-3-carboxylic acid (5), (1.06 mmol, $200.5 \mathrm{mg})$ and HBTU (1.3 mmol, $493 \mathrm{mg})$ in DCM (1.6 mL), was added triethylamine (2.54 mmol, 0.35 $\mathrm{mL}$ ) at ambient temperature. The mixture became homogeneous and was allowed to stir for 10 minutes before 4-tert-butylaniline $(2.12 \mathrm{mmol}, 316.4 \mathrm{mg})$ was added dropwise. The reaction mixture was stirred at room temperature overnight. The suspension formed was diluted with DCM and extracted with $0.1 \mathrm{M} \mathrm{HCl}(\times 2), \mathrm{NaHCO}_{3}(\times 2)$ and half saturated $\mathrm{NaCl}(\times 2)$. The organic layer was filtered and the collected precipitate was dried under vacuum to afford the product as a white solid in a $60 \%$ yield $(204 \mathrm{mg}),\left(\mathrm{mp}=244-246{ }^{\circ} \mathrm{C}\right) . \mathrm{R}_{\mathrm{f}}=0.29\left(\mathrm{SiO}_{2}, 50 \%\right.$ DCM:Ether); ${ }^{1} \mathrm{H}-\mathrm{NMR}\left(400 \mathrm{MHz},\left(\mathrm{CD}_{3}\right)_{2} \mathrm{SO}\right), \delta 12.96$ (br. s, $\left.1 \mathrm{H}\right), 12.40$ (s, 1H), 8.87 (s, 1H), $8.33(\mathrm{~d}, J=8.5 \mathrm{~Hz}, 1 \mathrm{H}), 7.81(\mathrm{t}, J=7 \mathrm{~Hz}, 1 \mathrm{H}), 7.75(\mathrm{~d}, J=7.5 \mathrm{~Hz}, 1 \mathrm{H}), 7.65(\mathrm{~d}, J=8.5 \mathrm{~Hz}$ 2H), $7.54(\mathrm{t}, J=7 \mathrm{~Hz}, 1 \mathrm{H}), 7.38(\mathrm{~d}, J=8.5 \mathrm{~Hz}, 2 \mathrm{H}), 1.28(\mathrm{~s}, 9 \mathrm{H}),{ }^{13} \mathrm{C}-\mathrm{NMR}(100 \mathrm{MHz}$, 
$\left.\left(\mathrm{CD}_{3}\right)_{2} \mathrm{SO}\right), \delta 176.76,163.11,146.16,144.52,139.61,136.71,133.40,126.40,126.08,125.90$ 125.70, 119.76, 119.66, 111.11, 34.51, 31.67. HPLC $t_{R}=34.51 \mathrm{~min}$.

\section{$\underline{N-(2-(t e r t-b u t y l) p h e n y l)-4-0 x 0-1,4-d i h y d r o q u i n o l i n e-3-c a r b o x a m i d e ~(19): ~}$}<smiles>O=C(O)c1c[nH]c2ccccc2c1=O</smiles>

(5)<smiles>CC(C)(C)c1ccccc1N</smiles><smiles>[R19]C(=O)Nc1ccccc1</smiles><smiles>CC(C)(C)c1ccccc1NC(=O)c1c[nH]c2ccccc2c1=O</smiles>

(19)

$48 \%$

To a suspension of 4-oxo-1,4-dihydroquinoline-3-carboxylic acid (5), (1.06 mmol, $200.5 \mathrm{mg})$ and HBTU (1.3 mmol, $493 \mathrm{mg})$ in DCM (1.6 mL), was added triethylamine (2.54 mmol, 0.35 $\mathrm{mL})$ at ambient temperature. The mixture was allowed to stir for 10 minutes before 2-tertbutylaniline ( $2.12 \mathrm{mmol}, 316.4 \mathrm{mg})$ was added dropwise. The reaction mixture was stirred at room temperature overnight. An orange suspension formed that was diluted with DCM and extracted with $0.1 \mathrm{M} \mathrm{HCl}(\times 2), \mathrm{NaHCO}_{3}(\times 2)$ and half saturated $\mathrm{NaCl}(\times 2)$. The organic layer was dried over $\mathrm{MgSO}_{4}$ and concentrated under vacuum. The resulting solid was redissolved in ether and extracted against $\mathrm{NaHCO}_{3}(\times 2)$. The organic layer was dried over $\mathrm{MgSO}_{4}$ and evaporated to give the desired product as a beige solid in a $48 \%$ yield $(162.5 \mathrm{mg}),(\mathrm{mp}=171-175$ $\left.{ }^{\circ} \mathrm{C}\right) . \mathrm{R}_{\mathrm{f}}=0.33\left(\mathrm{SiO}_{2}, 50 \%\right.$ DCM:Ether); ${ }^{1} \mathrm{H}-\mathrm{NMR}\left(400 \mathrm{MHz},\left(\mathrm{CD}_{3}\right)_{2} \mathrm{SO}\right), \delta 12.92$ (br. s, $\left.1 \mathrm{H}\right)$, $11.99(\mathrm{~s}, 1 \mathrm{H}), 8.88(\mathrm{~s}, 1 \mathrm{H}), 8.33(\mathrm{dd}, J=1.2 \mathrm{~Hz}, J=8.4 \mathrm{~Hz}, 1 \mathrm{H}), 7.84-7.78(\mathrm{~m}, 1 \mathrm{H}), 7.75(\mathrm{~d}, J=$ $7.2 \mathrm{~Hz}, 1 \mathrm{H}), 7.57(J=1.6 \mathrm{~Hz}, J=8 \mathrm{~Hz}, 1 \mathrm{H}), 7.52(\mathrm{ddd}, J=1.2 \mathrm{~Hz}, J=7.2 \mathrm{~Hz}, J=8.4 \mathrm{~Hz}, 1 \mathrm{H})$, $7.42(\mathrm{dd}, J=1.6 \mathrm{~Hz}, J=8 \mathrm{~Hz}, 1 \mathrm{H}), 7.23(\mathrm{ddd}, J=3.2 \mathrm{~Hz}, J=7.6 \mathrm{~Hz}, J=7.6 \mathrm{~Hz}, 1 \mathrm{H}), 7.16(\mathrm{ddd}$, $J=2.8 \mathrm{~Hz}, J=8 \mathrm{~Hz}, J=8 \mathrm{~Hz}, 1 \mathrm{H}), 1.42(\mathrm{~s}, 9 \mathrm{H}),{ }^{13} \mathrm{C}-\mathrm{NMR}\left(100 \mathrm{MHz},\left(\mathrm{CD}_{3}\right)_{2} \mathrm{SO}\right), \delta 176.89$, $163.51,144.74,143.29,139.60,135.91,133.41,128.97,126.65,126.48,126.44,126.01,125.78$, $125.64,119.60,111.16,34.86,30.63$. HPLC $t_{R}=28.67 \mathrm{~min}$. 
$\underline{N-(3-h y d r o x y p h e n y l)-4-o x o-1,4-d i h y d r o q u i n o l i n e-3-c a r b o x a m i d e ~(20): ~}$

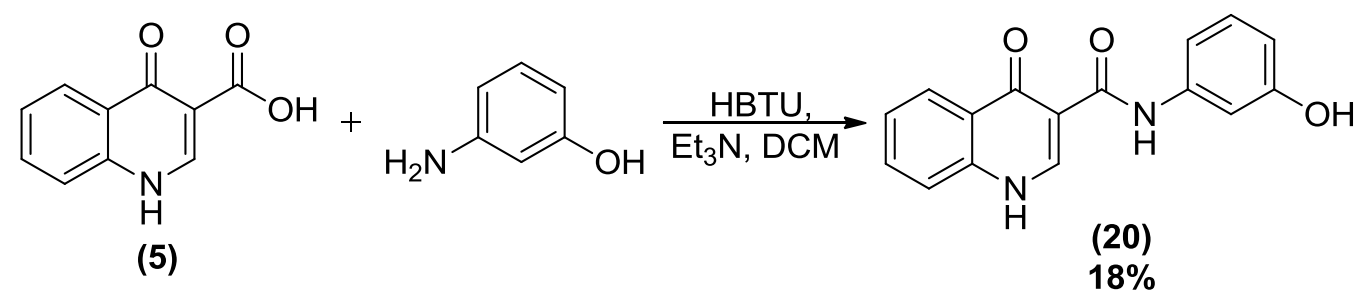

To a suspension of 4-oxo-1,4-dihydroquinoline-3-carboxylic acid (5), (1.06 mmol, $200.5 \mathrm{mg})$ and HBTU (1.3 mmol, $493 \mathrm{mg})$ in DCM (1.6 mL), was added triethylamine $(2.54 \mathrm{mmol}, 0.35$ $\mathrm{mL}$ ) at ambient temperature. The mixture became clear brown solution and was allowed to stir for 10 minutes before 3-aminophenol $(2.12 \mathrm{mmol}, 231.4 \mathrm{mg})$ was added in small portions. The reaction mixture was stirred at room temperature overnight. The solution was quenched with $\mathrm{H}_{2} \mathrm{O}$, then was diluted with DCM and extracted with $0.1 \mathrm{M} \mathrm{HCl}(\times 1)$. The organic layer became a suspension and was filtered. The resulting precipitate was redissolved in excess ethyl acetate and extracted with $0.1 \mathrm{M} \mathrm{HCl}(\times 2), \mathrm{NaHCO}_{3}(\times 2)$ and half saturated $\mathrm{NaCl}(\times 2)$. The organic layer was dried over $\mathrm{MgSO}_{4}$ and concentrated under vacuum to give a beige solid (18\% yield) $(52.5 \mathrm{mg}),\left(\mathrm{mp}=185-190{ }^{\circ} \mathrm{C}\right) . \mathrm{R}_{\mathrm{f}}=0.19\left(\mathrm{SiO}_{2}, 50 \%\right.$ DCM:Ether $) ;{ }^{1} \mathrm{H}-\mathrm{NMR}(400 \mathrm{MHz}$, $\left.\left(\mathrm{CD}_{3}\right)_{2} \mathrm{SO}\right), \delta 12.94$ (br. s, $\left.1 \mathrm{H}\right), 12.39(\mathrm{~s}, 1 \mathrm{H}), 9.46(\mathrm{~s}, 1 \mathrm{H}), 8.86(\mathrm{~s}, 1 \mathrm{H}), 8.33(\mathrm{dd}, J=1.2 \mathrm{~Hz}, J=$ 8.4 Hz, 1H), 7.84-7.78 (m, 1H), $7.75(\mathrm{~d}, J=7.5 \mathrm{~Hz}, 1 \mathrm{H}), 7.54(\mathrm{ddd}, J=1.2 \mathrm{~Hz}, J=7.2 \mathrm{~Hz}, J=$ $8.4 \mathrm{~Hz}, 1 \mathrm{H}), 7.34(\mathrm{dd}, J=2 \mathrm{~Hz}, J=2 \mathrm{~Hz}, 1 \mathrm{H}), 7.13(\mathrm{dd}, J=8 \mathrm{~Hz}, J=8 \mathrm{~Hz}, 1 \mathrm{H}), 7.04-6.99$ (m, 1H), 6.49 (ddd, $J=0.8 \mathrm{~Hz}, J=2.4 \mathrm{~Hz}, J=8 \mathrm{~Hz}, 1 \mathrm{H}),{ }^{13} \mathrm{C}-\mathrm{NMR}\left(100 \mathrm{MHz},\left(\mathrm{CD}_{3}\right)_{2} \mathrm{SO}\right), \delta$ $176.79,163.11,158.30,144.58,140.27,139.57,133.45,130.15,126.38,125.93,125.73,119.65$ 111.10, 111.01, 110.72, 107.11. HPLC $t_{R}=19.15 \mathrm{~min}$. 
$\underline{N \text {-(4-butoxyphenyl)-4-oxo-1,4-dihydroquinoline-3-carboxamide (21): }}$<smiles>CCCCOc1ccc(NC(=O)c2c[nH]c3ccc(N(OCC)C(=O)OCC)cc3c2=O)cc1</smiles>

To a suspension of 4-oxo-1,4-dihydroquinoline-3-carboxylic acid (5), (1.06 mmol, $200.5 \mathrm{mg})$ and HBTU (1.3 mmol, $493 \mathrm{mg})$ in DCM (1.6 mL), was added triethylamine $(2.54 \mathrm{mmol}, 0.35$ $\mathrm{mL})$ at ambient temperature, followed by DMAP $(0.106 \mathrm{mmol}, 13 \mathrm{mg})$. The mixture was allowed to stir for 10 minutes before 4-butoxyaniline $(2.12 \mathrm{mmol}, 0.35 \mathrm{~mL})$ was added dropwise. The reaction mixture was stirred at room temperature overnight. The formed suspension was diluted with DCM and filtered. The white precipitate was washed with DCM and dried under vacuum affording the desired product in $52 \%$ yield $(184 \mathrm{mg}),\left(\mathrm{mp}=268-269{ }^{\circ} \mathrm{C}\right) . \mathrm{R}_{\mathrm{f}}=0.24$ $\left(\mathrm{SiO}_{2}, 50 \%\right.$ DCM:Ether); ${ }^{1} \mathrm{H}-\mathrm{NMR}\left(400 \mathrm{MHz},\left(\mathrm{CD}_{3}\right)_{2} \mathrm{SO}\right) \delta 12.91$ (br s, $\left.1 \mathrm{H}\right), 12.31$ (s, $\left.1 \mathrm{H}\right), 8.86$ (s, 1H), $8.32(\mathrm{dd}, J=1.2 \mathrm{~Hz}, J=8 \mathrm{~Hz}, 1 \mathrm{H}), 7.84-7.75(\mathrm{~m}, 1 \mathrm{H}), 7.75(\mathrm{~d}, J=8 \mathrm{~Hz}, 1 \mathrm{H}), 7.60-$ $7.67(\mathrm{~m}, 2 \mathrm{H}), 7.53(\mathrm{dddd}, J=1.2 \mathrm{~Hz}, J=7.6 \mathrm{~Hz}, J=8 \mathrm{~Hz}, J=8 \mathrm{~Hz}, 1 \mathrm{H}), 5.90-6.60(\mathrm{~m}, 2 \mathrm{H})$, $3.95(\mathrm{t}, J=6.8 \mathrm{~Hz}, 2 \mathrm{H}), 1.69$ (quintet, $J=6.4 \mathrm{~Hz}, 2 \mathrm{H}), 1.44$ (sextet, $J=7.6 \mathrm{~Hz}, 2 \mathrm{H}), 0.94(\mathrm{t}, J=$ $7.2 \mathrm{~Hz}, 3 \mathrm{H}),{ }^{13} \mathrm{C}-\mathrm{NMR}\left(100 \mathrm{MHz},\left(\mathrm{CD}_{3}\right)_{2} \mathrm{SO}\right), \delta 176.74,162.81,155.23,144.36,139.55$, $133.39,132.36,126.37,125.90,125.67,121.42,119.61,115.18,111.20,67.75,31.27,19.21$, 14.16. 
Ethyl-3-oxo-3-(2,4,5-trifluorophenyl)propanoate (22):

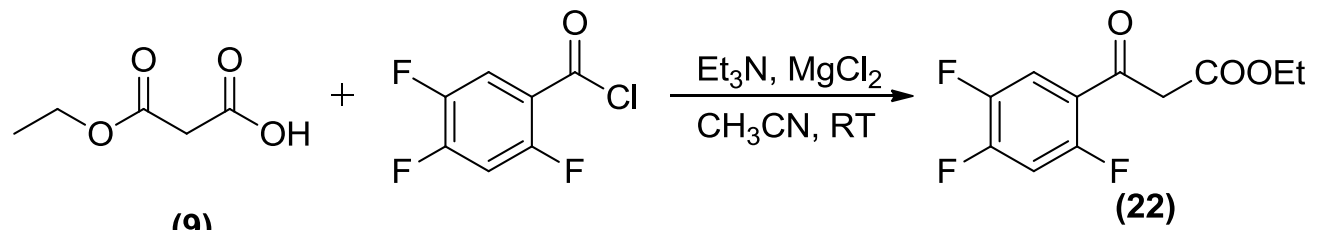

(9)

$95 \%$

A stirred solution of monoethyl malonate $(\mathbf{9}),(21 \mathrm{mmol}, 2.77 \mathrm{~g})$ in anhydrous acetonitrile $(33.2$ $\mathrm{mL})$ under argon and cooled in ice bath. To this mixture was added triethylamine (41.2 mmol, $5.74 \mathrm{~mL})$ followed by magnesium chloride $(25.7 \mathrm{mmol}, 2.45 \mathrm{~g}) .^{34}$ The mixture was warmed to room temperature and stirring was continued for $2.5 \mathrm{hrs}$. The resultant slurry was recooled to 0 ${ }^{\circ} \mathrm{C}$ and 2,4,5-trifluorobenzoyl chloride (10.2 $\left.\mathrm{mmol}, 1.3 \mathrm{~mL}\right)$ was added dropwise over $15 \mathrm{~min}$ followed by the addition of triethylamine $(2 \mathrm{mmol}, 0.28 \mathrm{~mL}) .{ }^{34}$ The mixture was stirred at room temperature overnight and then concentrated under vacuum to remove acetonitrile. Toluene (17 $\mathrm{mL})$ was added and then concentrated under vacuum. More toluene $(17 \mathrm{~mL})$ was added and the mixture was stirred and cooled in ice bath. Aqueous $\mathrm{HCl}(13 \%, 21 \mathrm{~mL})$ was added while the mixture was kept in ice bath and stirring was allowed for $10 \mathrm{~min}$. The aqueous layer was separated and the organic layer was washed with aqueous $\mathrm{HCl}(12 \%, 2 \times 20 \mathrm{~mL})$, followed by water $(2 \times 20 \mathrm{~mL})$. The organic layer was dried over $\mathrm{MgSO}_{4}$ and evaporated. The crude product was a mixture of keto and enol tautomers in a ratio of $1.5: 1$, respectively, and was separated as a yellow solid in a $95 \%$ yield $(2.4 \mathrm{~g}),\left(\mathrm{mp}=59-60^{\circ} \mathrm{C}\right)$. The crude NMR was compared to literature to approve the product. ${ }^{34} \mathrm{R}_{\mathrm{f}}=0.91\left(\mathrm{SiO}_{2}, 50 \%\right.$ EtOAc:Hexanes); ${ }^{1} \mathrm{H}-\mathrm{NMR}$ (enol form, 400 $\left.\mathrm{MHz}, \mathrm{CDCl}_{3}\right) \delta 12.70(\mathrm{~s}, 1 \mathrm{H}), 7.75-7.65(\mathrm{~m}, 1 \mathrm{H}), 7.08-6.90(\mathrm{~m}, 1 \mathrm{H}), 5.82(\mathrm{~s}, 1 \mathrm{H}), 4.28(\mathrm{q}, J=7$ $\mathrm{Hz}, 2 \mathrm{H}), 1.32(\mathrm{t}, J=7.2 \mathrm{~Hz}, 3 \mathrm{H})$, (keto form, $\left.400 \mathrm{MHz}, \mathrm{CDCl}_{3}\right) \delta$ 7.90-7.75 (m, 1H), 7.08-6.90 $(\mathrm{m}, 1 \mathrm{H}), 4.20(\mathrm{q}, J=8.4 \mathrm{~Hz}, 2 \mathrm{H}), 3.94(\mathrm{~s}, 2 \mathrm{H}), 1.30-1.22(\mathrm{~m}, 3 \mathrm{H}) .^{34}$ 
Ethyl-3-(dimethylamino)-2-(2,4,5-trifluorobenzoyl)acrylate (23):

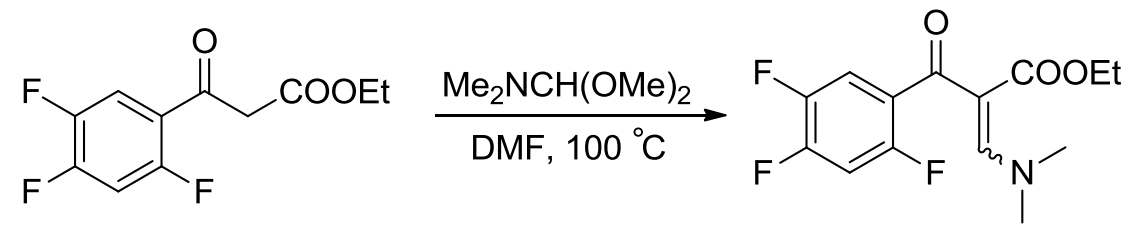

(22)

(23)

$87 \%$

A $50 \mathrm{~mL}$ Schlenk flask, equipped with a reflux condenser and an argon inlet, was charged with ethyl-3-oxo-3-(2,4,5-trifluorophenyl)propanoate (22), (12.19 $\mathrm{mmol}, 3 \mathrm{~g})$ and $15 \mathrm{~mL}$ of anhydrous DMF. The resulting solution was heated to $100{ }^{\circ} \mathrm{C}$ and $N, N$-dimethylformamide dimethyl acetal $(12.19 \mathrm{mmol}, 1.6 \mathrm{~mL})$ was added and the temperature was kept at $100{ }^{\circ} \mathrm{C}$ for 2 hrs. ${ }^{32}$ The crude reaction mixture was quenched with ice cold water, stirred for 5 minutes and extracted with ether $(\times 3)$. The aqueous layer was saturated with brine and re-extracted with ether. The combined ether layers were washed with brine, dried over $\mathrm{MgSO}_{4}$ and concentrated under vacuum yielding the product as orange yellow oil in $87 \%$ yield (3.2 g). The resulting oil was used in the next step without any further purification. $\mathrm{R}_{\mathrm{f}}=0.26\left(\mathrm{SiO}_{2}, 50 \%\right.$ EtOAc:Hexanes); ${ }^{1} \mathrm{H}-\mathrm{NMR}\left(400 \mathrm{MHz}, \mathrm{CDCl}_{3}\right) \delta 7.78(\mathrm{~s}, 1 \mathrm{H}), 7.45$ (ddd, $J=8 \mathrm{~Hz}, J=8 \mathrm{~Hz}, J=$ $8 \mathrm{~Hz}, 1 \mathrm{H}), 6.87(\mathrm{ddd}, J=9 \mathrm{~Hz}, J=9 \mathrm{~Hz}, J=9 \mathrm{~Hz}, 1 \mathrm{H}), 4.01$ (q, $J=5.2 \mathrm{~Hz}, 2 \mathrm{H}), 2.95$ (s, 3H), $2.88(\mathrm{~s}, 3 \mathrm{H}), 0.99(\mathrm{t}, J=8 \mathrm{~Hz}, 3 \mathrm{H})$. 
(Z)-ethyl-3-(tert-butylamino)-2-(2,4,5-trifluorobenzoyl)acrylate (24):<smiles>CCOC(=O)/C(=C/N(C)C)C(=O)c1cc(F)c(F)cc1F</smiles>

(23)

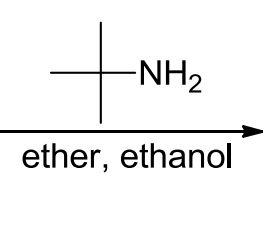

$\underset{\text { ther, ethanol }}{\stackrel{\mathrm{NH}_{2}}{\longrightarrow}}$<smiles>CCOC(=O)/C(=C\NC(C)(C)C)C(=O)c1cc(F)c(F)cc1F</smiles>

Ethyl-3-(dimethylamino)-2-(2,4,5-trifluorobenzoyl)acrylate $(\mathbf{2 3}), \quad(9.96 \mathrm{mmol}, 3.07 \mathrm{~g})$ was dissolved in a 2:1 ether/ethanol mixture (16 and $8 \mathrm{~mL}$, respectively) at room temperature. $t$-Butyl amine (2 eq., $19.92 \mathrm{mmol}, 2.1 \mathrm{~mL}$ ) was added dropwise and let the mixture stirring at room temperature for 5 hrs. ${ }^{38}$ The solvents were evaporated in vacuum to get the desired crude product as an orange yellow oil in $90 \%$ yield $(2.95 \mathrm{~g}) . \mathrm{R}_{\mathrm{f}}=0.63\left(\mathrm{SiO}_{2}, 50 \%\right.$ EtOAc:Hexanes $) ;{ }^{1} \mathrm{H}-\mathrm{NMR}$ $\left(400 \mathrm{MHz}, \mathrm{CDCl}_{3}\right) \delta 11.28(\mathrm{~d}, J=13.6 \mathrm{~Hz}, 1 \mathrm{H}), 8.26-8.18(\mathrm{~m}, 1 \mathrm{H}), 7.19(\mathrm{dd}, J=6 \mathrm{~Hz}, J=9.2$ $\mathrm{Hz}, 1 \mathrm{H}), 6.86(\mathrm{dd}, J=6 \mathrm{~Hz}, J=9.6 \mathrm{~Hz}, 1 \mathrm{H}), 4.03(\mathrm{q}, J=7.2 \mathrm{~Hz}, 2 \mathrm{H}), 1.42(\mathrm{~s}, 9 \mathrm{H}), 1.05(\mathrm{t}, J=$ $6.4 \mathrm{~Hz}, 3 \mathrm{H})$.

Ethyl-1-(tert-butyl)-6,7-difluoro-4-oxo-1,4-dihydroquinoline-3-carboxylate (25):<smiles>CCOC(=O)/C(=C\NC(C)(C)C)C(=O)c1cc(F)c(F)cc1F</smiles>

(24)<smiles>CCOC(=O)c1cn(C(C)(C)C)c2cc(F)c(F)cc2c1=O</smiles>

A suspension of $\mathrm{NaH}(11.23 \mathrm{mmol}, 449.2 \mathrm{mg})$ in $\mathrm{DMF}(24.1 \mathrm{~mL})$ was cooled to $0{ }^{\circ} \mathrm{C}$ and treated dropwise with (Z)-ethyl-3-(tert-butylamino)-2-(2,4,5-trifluorobenzoyl)acrylate (24), (9.38 mmol, $3.09 \mathrm{~g})$ in DMF $(8 \mathrm{~mL}) .{ }^{39}$ The reaction mixture was stirred at room temperature for $5 \mathrm{hrs}$. The reaction mixture was poured into ice water and filtered. The resulting precipitate was separated, washed with water and then dried under vacuum to yield the desired product as a yellowish white 
solid $(32 \%)(928 \mathrm{mg}),\left(\mathrm{mp}=180-181{ }^{\circ} \mathrm{C}\right) . \mathrm{R}_{\mathrm{f}}=0.19\left(\mathrm{SiO}_{2}, 50 \%\right.$ EtOAc:Hexanes $) ;{ }^{1} \mathrm{H}-\mathrm{NMR}$ $\left(400 \mathrm{MHz}, \mathrm{CDCl}_{3}\right) \delta 8.76(\mathrm{~s}, 1 \mathrm{H}), 8.15(\mathrm{dd}, J=9.6 \mathrm{~Hz}, J=10.4 \mathrm{~Hz}, 1 \mathrm{H}), 7.65(\mathrm{dd}, J=6.4 \mathrm{~Hz}, J$ $=12.8 \mathrm{~Hz}, 1 \mathrm{H}), 4.23(\mathrm{q}, J=7.2 \mathrm{~Hz}, 2 \mathrm{H}), 1.78(\mathrm{~s}, 9 \mathrm{H}), 1.26(\mathrm{t}, J=6.8 \mathrm{~Hz}, 3 \mathrm{H}),{ }^{13} \mathrm{C}-\mathrm{NMR}(100$ $\left.\mathrm{MHz}, \mathrm{CDCl}_{3}\right), \delta 171.87,165.57,149.73(\mathrm{dd}, J=251 \mathrm{~Hz}, J=396 \mathrm{~Hz}), 149.60(\mathrm{dd}, J=252 \mathrm{~Hz}, J$ $=395 \mathrm{~Hz}), 146.32,135.47(\mathrm{dd}, J=2 \mathrm{~Hz}, J=9 \mathrm{~Hz}), 115.42(\mathrm{dd}, J=2 \mathrm{~Hz}, J=18 \mathrm{~Hz}), 128.08$, $109.28(\mathrm{~d}, J=31 \mathrm{~Hz}), 108.88,63.57,60.74,30.38,14.29,{ }^{19} \mathrm{~F}-\mathrm{NMR}\left(376.5 \mathrm{MHz}, \mathrm{CDCl}_{3}\right), \delta$ $128.26(\mathrm{~d}, J=22.6 \mathrm{~Hz}), 139.19(\mathrm{~d}, J=26.36 \mathrm{~Hz})$.

Ethyl-7-azido-1-(tert-butyl)-6-fluoro-4-oxo-1,4-dihydroquinoline-3-carboxylate (26):

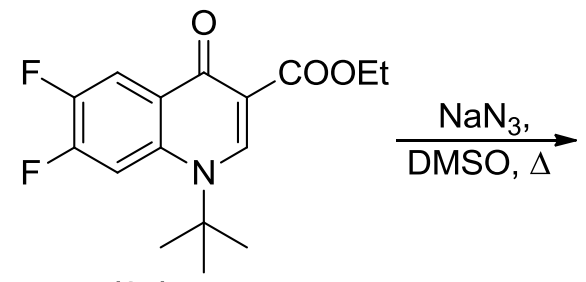

(25)<smiles>CCOC(=O)c1cn(C(C)(C)C)c2cc(N)c(F)cc2c1=O</smiles>

To a solution of ethyl-1-(tert-butyl)-6,7-difluoro-4-oxo-1,4-dihydroquinoline-3-carboxylate (25), $(1.048 \mathrm{mmol}, 324.4 \mathrm{mg})$ in DMSO $(10 \mathrm{~mL}), 5$ eq. of sodium azide $(5.24 \mathrm{mmol}, 340.7 \mathrm{mg})$ was added. The reaction mixture was heated to $100{ }^{\circ} \mathrm{C}$ overnight. After cooling to room temperature, the reaction was quenched with water and extracted against ether $(\times 4)$. The combined organic layers were dried over $\mathrm{MgSO}_{4}$ and evaporated. The desired compound was isolated by column chromatography (30\% acetone-hexanes) as a yellow solid in $30 \%$ yield containing other impurities such as diazido compound, $\left(\mathrm{mp}=147-148{ }^{\circ} \mathrm{C}\right) .{ }^{1} \mathrm{H}-\mathrm{NMR}\left(400 \mathrm{MHz}, \mathrm{CDCl}_{3}\right) \delta 8.83$ (s, 1H), $8.21(\mathrm{~d}, J=11.6 \mathrm{~Hz}, 1 \mathrm{H}), 7.46(\mathrm{~d}, J=6.4 \mathrm{~Hz}, 1 \mathrm{H}), 4.35(\mathrm{q}, J=7.2 \mathrm{~Hz}, 2 \mathrm{H}), 1.83(\mathrm{~s}, 9 \mathrm{H})$, $1.37(\mathrm{t}, J=7.2 \mathrm{~Hz}),{ }^{19} \mathrm{~F}-\mathrm{NMR}\left(376.5 \mathrm{MHz}, \mathrm{CDCl}_{3}\right), \delta 128.76$. 
7-Azido-1-(tert-butyl)-6-fluoro-4-oxo-1,4-dihydroquinoline-3-carboxylic acid (27):<smiles>CCOC(=O)c1cn(C(C)(C)C)c2cc(N)c(F)cc2c1=O</smiles>

Ethyl-7-azido-1-(tert-butyl)-6-fluoro-4-oxo-1,4-dihydroquinoline-3-carboxylate $\quad(\mathbf{2 6}), \quad(0.26$ mmol, $86.7 \mathrm{mg}$ ) was suspended in $2 \mathrm{~N}$ aqueous $\mathrm{NaOH}(1 \mathrm{~mL})$, and the mixture was heated to reflux overnight. ${ }^{45}$ After cooling to room temperature, the reaction mixture was acidified using 2 $\mathrm{N} \mathrm{HCl}$ to $\mathrm{pH}$ 4. The resulting precipitate was filtered, washed with water and dried under vacuum to yield the desired product as a yellow solid in a $72 \%$ yield that was used without further purification $\left(\mathrm{mp}=172-174{ }^{\circ} \mathrm{C}\right), \mathrm{R}_{\mathrm{f}}=0.44\left(\mathrm{SiO}_{2}, 50 \% \mathrm{DCM}:\right.$ Ether $) ;{ }^{1} \mathrm{H}-\mathrm{NMR}(400 \mathrm{MHz}$, $\left.\left(\mathrm{CD}_{3}\right)_{2} \mathrm{SO}\right), \delta 14.9$ (br. s, $\left.1 \mathrm{H}\right), 8.98(\mathrm{~s}, 1 \mathrm{H}), 8.19(\mathrm{~d}, J=12 \mathrm{~Hz}, 1 \mathrm{H}), 7.88(\mathrm{~d}, J=4 \mathrm{~Hz}, 1 \mathrm{H}), 1.87$ $(\mathrm{s}, 9 \mathrm{H}),{ }^{19} \mathrm{~F}-\mathrm{NMR}\left(376.5 \mathrm{MHz},\left(\mathrm{CD}_{3}\right)_{2} \mathrm{SO}\right), \delta 127.39$.

\section{7-Azido-1-(tert-butyl)-N-(4-(tert-butyl)phenyl)-6-fluoro-4-oxo-1,4-dihydroquinoline-3-} carboxamide (28):<smiles>CCOCCN(C)C(C)(C)C(C)(C)c1ccc(N)cc1</smiles>

To a suspension of 7-azido-1-(tert-butyl)-6-fluoro-4-oxo-1,4-dihydroquinoline-3-carboxylic acid (27), (0.033 mmol, $10 \mathrm{mg})$ and HBTU (5 eq., $0.165 \mathrm{mmol}, 62.58 \mathrm{mg})$ in DCM (1 mL), was added triethylamine $(0.32 \mathrm{mmol}, 0.05 \mathrm{~mL})$ at ambient temperature, followed by DMAP $(0.003$ mmol, $0.5 \mathrm{mg}$ ). The mixture was allowed to stir for 10 minutes before 4-t-butyl aniline (5 eq., 
$0.165 \mathrm{mmol}, 0.03 \mathrm{~mL}$ ) was added. The reaction mixture was stirred at room temperature overnight. The formed suspension was diluted with DCM and extracted sequentially with $0.1 \mathrm{M}$ $\mathrm{HCl}(\times 2), \mathrm{NaHCO}_{3}(\times 2)$, and half saturated brine $(\times 2)$. The combined organic layers were dried over $\mathrm{MgSO}_{4}$ and concentrated under vacuum affording the desired crude product $(6 \mathrm{mg})$ as orange oil. $\mathrm{R}_{\mathrm{f}}=0.61\left(\mathrm{SiO}_{2}, 50 \%\right.$ EtOAc:Hexanes $) ;{ }^{1} \mathrm{H}-\mathrm{NMR}\left(400 \mathrm{MHz}, \mathrm{CDCl}_{3}\right) \delta 12.03(\mathrm{~s}, 1 \mathrm{H})$, $9.26(\mathrm{~s}, 1 \mathrm{H}), 8.32(\mathrm{~d}, J=11.6 \mathrm{~Hz}, 1 \mathrm{H}), 7.71-7.66(\mathrm{~m}, 2 \mathrm{H}), 7.59(\mathrm{~d}, J=6.4 \mathrm{~Hz}, 1 \mathrm{H}), 7.40-7.35$ $(\mathrm{m}, 2 \mathrm{H}), 1.91(\mathrm{~s}, 9 \mathrm{H}), 1.33(\mathrm{~s}, 9 \mathrm{H}),{ }^{19} \mathrm{~F}-\mathrm{NMR}\left(376.5 \mathrm{MHz},\left(\mathrm{CD}_{3}\right)_{2} \mathrm{SO}\right), \delta 128.33$.

\section{3-Benzamidophenylbenzoate (29):}

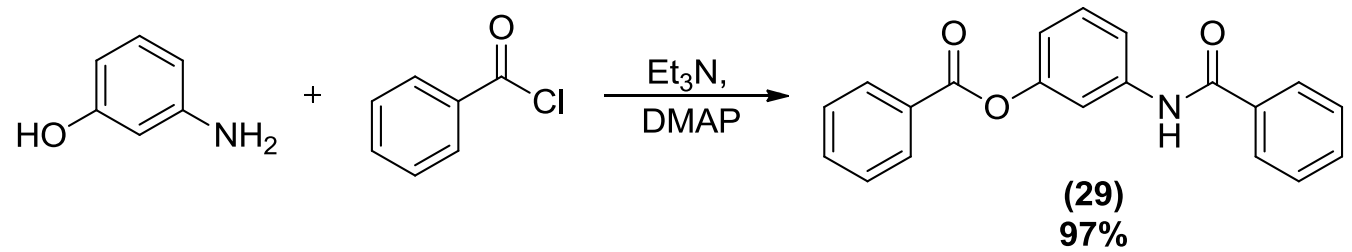

A solution of benzoyl chloride $(21.3 \mathrm{mmol}, 3 \mathrm{~g})$ in $15 \mathrm{~mL}$ of THF was added dropwise at room temperature to a solution of $m$-aminophenol $(10 \mathrm{mmol}, 1.09 \mathrm{~g})$, 4-dimethylaminopyridine (20 $\mathrm{mg}$ ), and triethylamine ( $25 \mathrm{mmol}, 2.54 \mathrm{~g}$ ) in $30 \mathrm{~mL}$ of THF. ${ }^{40}$ After stirring for $2 \mathrm{hrs}$, the formed precipitate was filtered off and washed with ether. The combined filtrate was concentrated under vacuum and the resulting solid was purified by column chromatography (7\% ethyl acetate hexanes) to give the title compound as white crystalline solid $(3.1 \mathrm{~g}, 97 \%),\left(\mathrm{mp}=140-141{ }^{\circ} \mathrm{C}\right)$. $\mathrm{R}_{\mathrm{f}}=0.53\left(\mathrm{SiO}_{2}, 50 \%\right.$ EtOAc:Hexanes $) ;{ }^{1} \mathrm{H}-\mathrm{NMR}\left(400 \mathrm{MHz}, \mathrm{CDCl}_{3}\right), \delta 8.21(\mathrm{~d}, J=8.2 \mathrm{~Hz}, 2 \mathrm{H})$, 7.95 (br. s, 1H), $7.86(\mathrm{~d}, J=4 \mathrm{~Hz}, 2 \mathrm{H}), 7.72(\mathrm{t}, J=2 \mathrm{~Hz}, 1 \mathrm{H}), 7.65(\mathrm{t}, J=7.6 \mathrm{~Hz}, 1 \mathrm{H}), 7.58$ 7.53-7.44 (m, 6H), $7.40(\mathrm{t}, J=8 \mathrm{~Hz}, 1 \mathrm{H}), 7.02-6.97(\mathrm{~m}, 1 \mathrm{H}),{ }^{13} \mathrm{C}-\mathrm{NMR}\left(400 \mathrm{MHz}, \mathrm{CDCl}_{3}\right), \delta$ $165.83,165.33,151.26,139.20,134.72,133.71,131.90,130.23,129.71,129.37,128.72,128.60$, 127.10, 117.58, 117.56, 113.90 . 


\section{(4-amino-2-hydroxyphenyl)phenyl)methanone (31):}

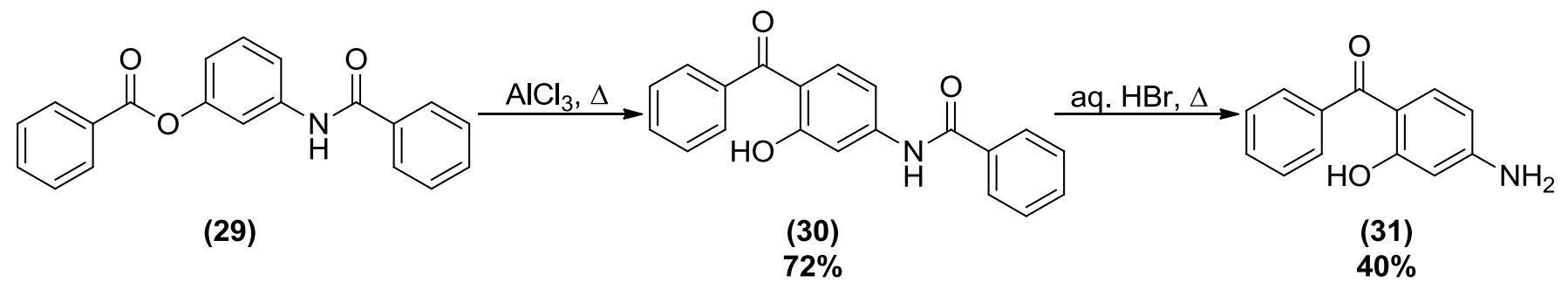

In the absence of solvent, 3-benzamidophenylbenzoate (29), (3 mmol, $952.1 \mathrm{mg})$ was mixed with 2 eq. of aluminum chloride $(6 \mathrm{mmol}, 800.1 \mathrm{mg})$. The mixture was heated on a mantle till melting for 15 minutes. After cooling to room temperature, $5 \mathrm{~N} \mathrm{HCl}(30 \mathrm{~mL})$ was added and the mixture was then extracted with ethyl acetate $(\times 3), \mathrm{NaOH}(\times 2)$ and brine. The organic layer was dried over magnesium sulfate and evaporated to give the desired product, $N$-(4-benzoyl-3hydroxyphenyl)benzamide, $\mathbf{3 0}$, in $72 \%$ yield $(686.6 \mathrm{mg})$. The crude product $(2.164 \mathrm{mmol}, 686.6$ $\mathrm{mg}$ ) was dissolved in $48 \%$ aqueous $\mathrm{HBr}(10.82 \mathrm{~mL}, 0.2 \mathrm{M}$ solution) and the solution was heated at $90{ }^{\circ} \mathrm{C}$ for 2 days. The reaction was quenched with water, extracted with ethyl acetate $(\times 3)$, $\mathrm{NaOH}(\times 2)$ and brine $(\times 2)$. The combined organic layer was dried over magnesium sulfate and evaporated. The desired product was isolated by column chromatography (15\% ethyl acetatehexanes) in $44 \%$ yield as brown solid $(204.3 \mathrm{mg}) . \mathrm{R}_{\mathrm{f}}=0.44\left(\mathrm{SiO}_{2}, 50 \%\right.$ EtOAc:Hexanes $) ;{ }^{1} \mathrm{H}-$ NMR (400 MHz, $\left(\mathrm{CDCl}_{3}\right) \delta 12.85(\mathrm{~s}, 1 \mathrm{H}), 7.60(\mathrm{~d}, J=7.6 \mathrm{~Hz}, 2 \mathrm{H}), 7.55-7.50(\mathrm{~m}, 1 \mathrm{H}), 7.50-7.43$ (m, 2H), $7.35(\mathrm{~d}, J=8.4 \mathrm{~Hz}, 1 \mathrm{H}), 6.19(\mathrm{~d}, J=2 \mathrm{~Hz}, 1 \mathrm{H}), 6.09(\mathrm{dd}, J=2 \mathrm{~Hz}, J=8.8 \mathrm{~Hz}, 1 \mathrm{H})$, 4.40 (br. s, 2H), ${ }^{13} \mathrm{C}-\mathrm{NMR}\left(400 \mathrm{MHz}, \mathrm{CDCl}_{3}\right), \delta$ 199.06, 166.36, 154.16, 138.65, 135.94, 130.99, $128.69,128.18,111.27,106.35,100.78$. 
$\underline{N-(3-h y d r o x y p h e n y l) b e n z a m i d e ~(34): ~}$

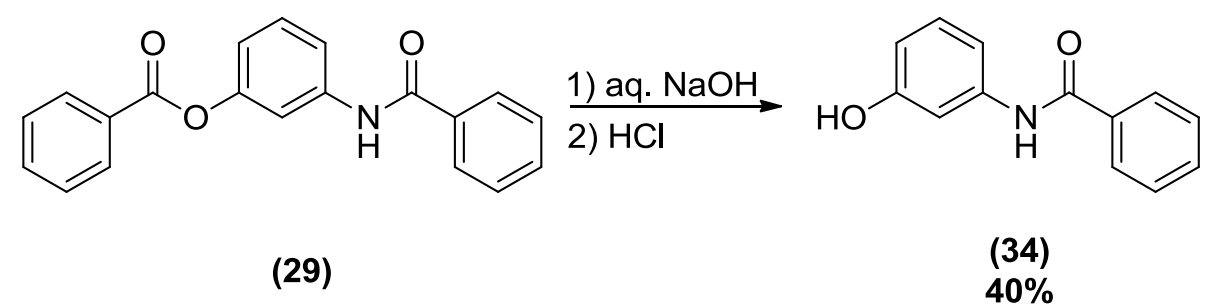

3-Benzamidophenylbenzoate $(\mathbf{2 9}),(1.59 \mathrm{mmol}, 503.3 \mathrm{mg})$ was suspended in aqueous sodium hydroxide solution $(2 \mathrm{~N}, 3.5 \mathrm{~mL})$ and the mixture was stirred at $60{ }^{\circ} \mathrm{C}$ overnight. After cooling to room temperature, the mixture was acidified to $\mathrm{pH} 4$ with $2 \mathrm{~N} \mathrm{HCl}^{45}$ The resulting grey precipitate was collected via filtration, washed with water and dried. The title compound was separated by column chromatography (35\% ethyl acetate-hexanes) as a white solid in a $40 \%$ yield $(135.3 \mathrm{mg}),\left(\mathrm{mp}=110-115{ }^{\circ} \mathrm{C}\right.$, lit. $\left.\mathrm{mp}=166-167{ }^{\circ} \mathrm{C}\right) .{ }^{49} \mathrm{R}_{\mathrm{f}}=0.38\left(\mathrm{SiO}_{2}, 50 \%\right.$ EtOAc:Hexanes); ${ }^{1} \mathrm{H}-\mathrm{NMR}\left(400 \mathrm{MHz},\left(\mathrm{CD}_{3}\right)_{2} \mathrm{CO}\right), \delta 9.55$ (s, 1H), 8.60 (br s, $\left.1 \mathrm{H}\right), 7.97$ (d, $J=$ $7.6 \mathrm{~Hz}, 2 \mathrm{H}), 7.68-7.61(\mathrm{~m}, 1 \mathrm{H}), 7.54(\mathrm{dd}, J=7.2 \mathrm{~Hz}, J=7.2 \mathrm{~Hz}, 1 \mathrm{H}), 7.46(\mathrm{dd}, J=8 \mathrm{~Hz}, J=8$ $\mathrm{Hz}, 2 \mathrm{H}), 7.29(\mathrm{~d}, J=8 \mathrm{~Hz}, 1 \mathrm{H}), 7.17(\mathrm{dd}, J=8 \mathrm{~Hz}, J=8 \mathrm{~Hz}, 1 \mathrm{H}), 6.69-6.63(\mathrm{~m}, 1 \mathrm{H}),{ }^{13} \mathrm{C}-\mathrm{NMR}$ $\left(100 \mathrm{MHz},\left(\mathrm{CD}_{3}\right)_{2} \mathrm{CO}\right), \delta 165.99,157.78,140.43,135.43,131.51,129.47,128.42,127.47$, 111.52, 111.06, 107.57. 
Diethyl-2-(((4-bromophenyl)amino)methylene)malonate (35):<smiles>CCOC(=O)C(=CNc1ccc(Br)cc1)C(=O)OCC</smiles>

To a solution of 4-bromoaniline (23.25 mmol, $4 \mathrm{~g})$ in $24 \mathrm{~mL}$ of ethanol, diethyl 2(ethoxymethylene)malonate $(23.25 \mathrm{mmol}, 4.7 \mathrm{~mL})$ was added and the mixture was heated to reflux $\left(78{ }^{\circ} \mathrm{C}\right)$ overnight. After cooling to room temperature, the mixture was dried by rotary evaporation under reduced pressure then left under vacuum for $4 \mathrm{hrs}$ to afford the desired compound quantitatively as a beige solid $(8 \mathrm{~g}),\left(\mathrm{mp}=95-96{ }^{\circ} \mathrm{C}\right) . \mathrm{R}_{\mathrm{f}}=0.59\left(\mathrm{SiO}_{2}, 50 \%\right.$ EtOAc:Hexanes); ${ }^{1} \mathrm{H}-\mathrm{NMR}\left(400 \mathrm{MHz}, \mathrm{CDCl}_{3}\right) \delta 10.98(\mathrm{~d}, J=13.5 \mathrm{~Hz}, 1 \mathrm{H}), 8.44(\mathrm{~d}, J=13.5$ $\mathrm{Hz}, 1 \mathrm{H}), 7.50-7.45(\mathrm{~m}, 2 \mathrm{H}), 7.05-6.98(\mathrm{~m}, 2 \mathrm{H}), 4.30(\mathrm{q}, J=7.2 \mathrm{~Hz}, 2 \mathrm{H}), 4.24(\mathrm{q}, J=7.2 \mathrm{~Hz}$ 2H), $1.37(\mathrm{t}, J=7.2 \mathrm{~Hz}, 3 \mathrm{H}), 1.32(\mathrm{t}, J=7.2 \mathrm{~Hz}, 3 \mathrm{H}),{ }^{13} \mathrm{C}-\mathrm{NMR}\left(100 \mathrm{MHz}, \mathrm{CDCl}_{3}\right), \delta 168.94$, $165.53,151.37,138.41,132.81,118.62,117.55,94.35,60.51,60.21,14.39,14.26$.

\section{6-Bromo-4-oxo-1,4-dihydroquinoline-3-carboxylic acid (37):}

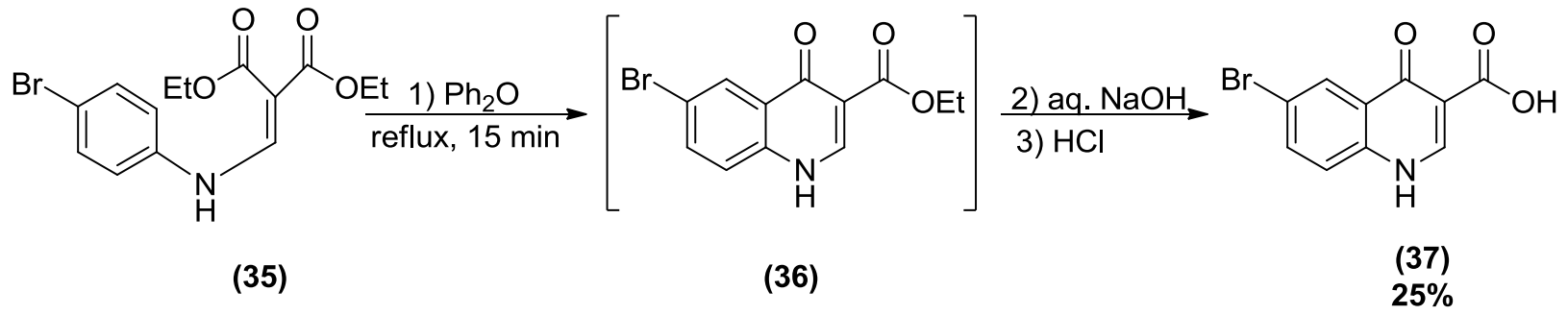

Diethyl-2-(((4-bromophenyl)amino)methylene)malonate (35), (23.96 mmol, $8.2 \mathrm{~g})$ was dissolved in $24 \mathrm{~mL}$ of diphenyl ether (1 M solution). Over a heating mantle, the solution was heated to reflux for 15 minutes to afford ethyl-6-bromo-4-oxo-1,4-dihydroquinoline-3-carboxylate. The resulting suspension was cooled to room temperature and then aqueous sodium hydroxide 
solution $(2 \mathrm{~N}, 52 \mathrm{~mL})$ was added. The mixture was stirred at reflux overnight. After cooling to room temperature, the mixture was extracted with ethyl acetate $(\times 3)$, and then the aqueous layer was acidified to $\mathrm{pH} 4$ with $2 \mathrm{~N} \mathrm{HCl}$. The resulting precipitate was collected via filtration, washed with water and dried under vacuum to afford the title compound as a pale white solid in a $25 \%$ yield $(1.6 \mathrm{~g}),\left(\mathrm{mp}=265-266{ }^{\circ} \mathrm{C}\right.$, lit. $\left.\mathrm{mp}=296.6{ }^{\circ} \mathrm{C}\right) .{ }^{50} \mathrm{R}_{\mathrm{f}}=0.10\left(\mathrm{SiO}_{2}, 50 \%\right.$ DCM:Ether $) ;{ }^{1} \mathrm{H}-$ NMR (400 MHz, $\left.\left(\mathrm{CD}_{3}\right)_{2} \mathrm{SO}\right) \delta 15.00$ (s, 1H), 13.58 (br. s, 1H), 8.93 (s, 1H), 8.35 (d, J = 2.4 Hz, $1 \mathrm{H}), 8.03(\mathrm{dd}, J=2.4 \mathrm{~Hz}, J=9 \mathrm{~Hz}, 1 \mathrm{H}), 7.78(\mathrm{~d}, J=9 \mathrm{~Hz}, 1 \mathrm{H}),{ }^{13} \mathrm{C}-\mathrm{NMR}(100 \mathrm{MHz}$, $\left.\left(\mathrm{CD}_{3}\right)_{2} \mathrm{SO}\right), 177.56,166.46,146.19,138.97,137.05,127.57,126.38,122.68,119.41,108.51$. 


\section{Conclusion}

VX770 is a cystic fibrosis drug, addressing CF patients carrying G551D mutation. It was developed by Vertex pharmaceuticals as a bioavailable potentiator. VX770 was recently, Feb. 2012, approved by the US FDA under the name of Kalydeco ${ }^{\mathrm{TM}}$. VX770 is a small molecule that can interact with the CFTR protein and help to increase the open probability of the chloride channel. The nature of molecular interaction between VX770 and the CFTR protein is still unknown. The goal of this research project was to develop synthetic methods toward VX770 and molecular probes based on its structure. The synthesis of labeled derivatives of VX770 will help to reveal the exact site of interaction on the CFTR protein.

The retrosynthesis strategy involves the disconnection of the amide to a carboxylic acid (LHS) and an amine (RHS). Studies were undertaken to prepare both of these fragments, as well as derivatives thereof.

For the synthesis of the LHS, different conditions were attempted. The classical method of refluxing the enamine in $\mathrm{Ph}_{2} \mathrm{O}$ was found to outperform any of the used protic or Lewis acids. Tandem reduction-addition-elimination reaction was another pursued approach for the synthesis for the LHS heterocycle. Although it was not a successful method for the synthesis of the LHS, it provided access to a fluoro-azido quinoline fragment, which should be useful in the synthesis of photoaffinity labels.

On the other hand, different approaches were pursued toward the synthesis of the RHS. The use of steric or electronic blocking groups failed to provide good amounts of the required nitro compound with the correct regiochemistry. Investigation of a strategy involving prior iodination 
of the more reactive ortho position was begun, showing some promise. Derivatives of aromatic amines with structural similarities to the RHS, but also photoreactive functional groups, were studied culminating with the synthesis of a benzophenone derivative.

Finally, the HBTU-mediated peptide coupling of LHS acids and RHS amines proceeded smoothly in most cases, and four different derivatives were prepared in quantities suitable for biological/biochemical testing, with a few others requiring re-synthesis to confirm structure and purity.

For future work, synthesis of the parent RHS amine will be pursued. Coupling of the parent RHS to the fluoro-azido LHS can be also attempted, which would be a useful photoaffinity probe. 
5. Appendix

틍

$-$ $\frac{\sqrt{\varepsilon \sigma^{\circ} \varepsilon}}{\sqrt{00^{\circ} \varepsilon}}$

|0.

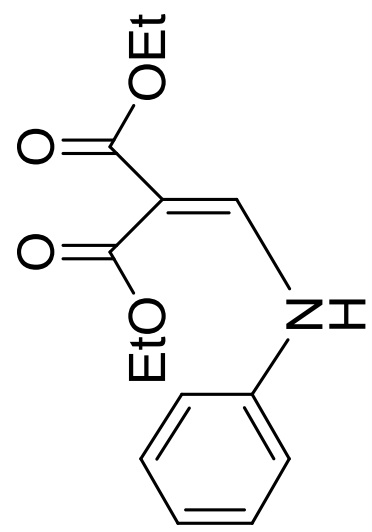



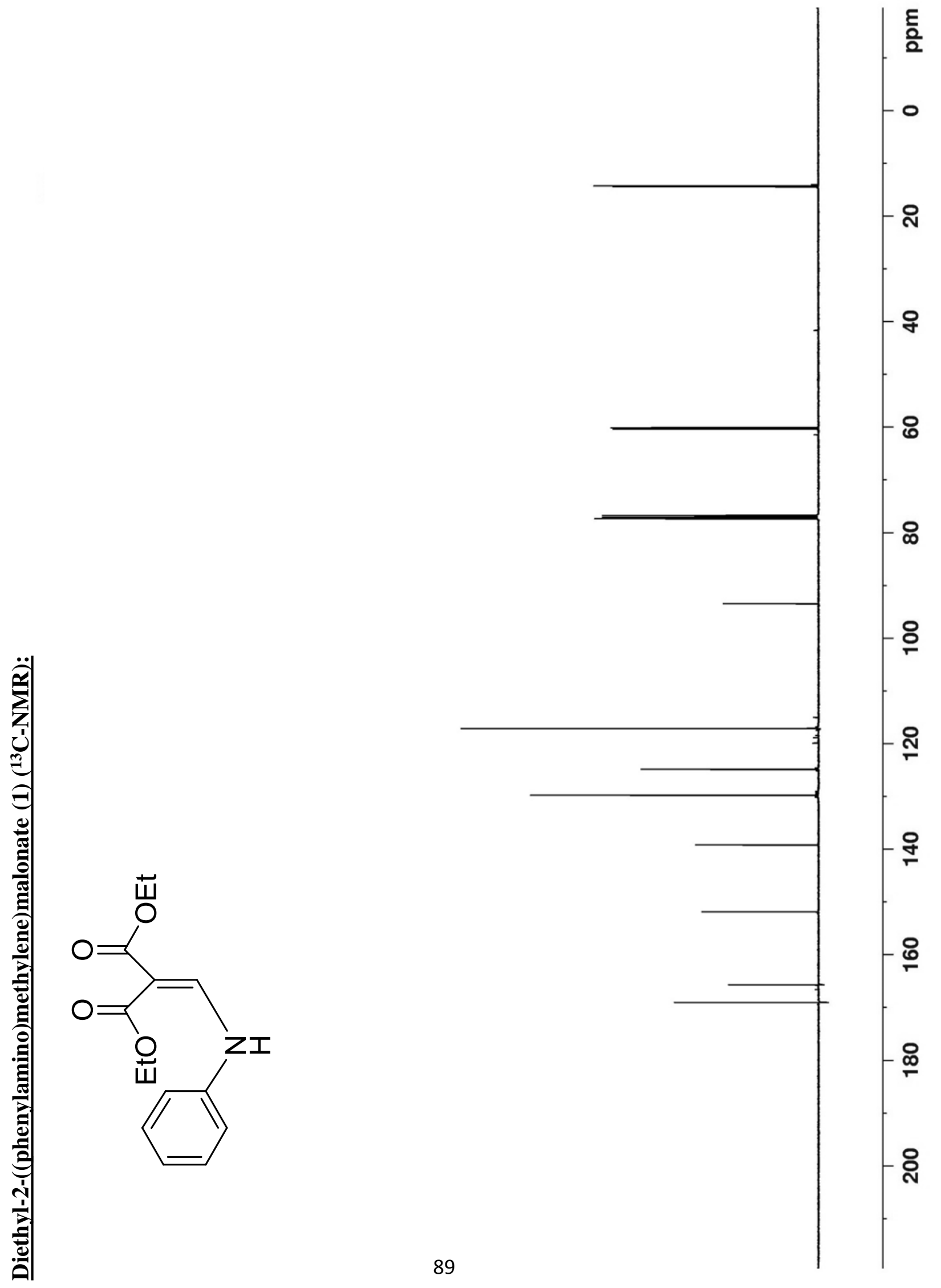


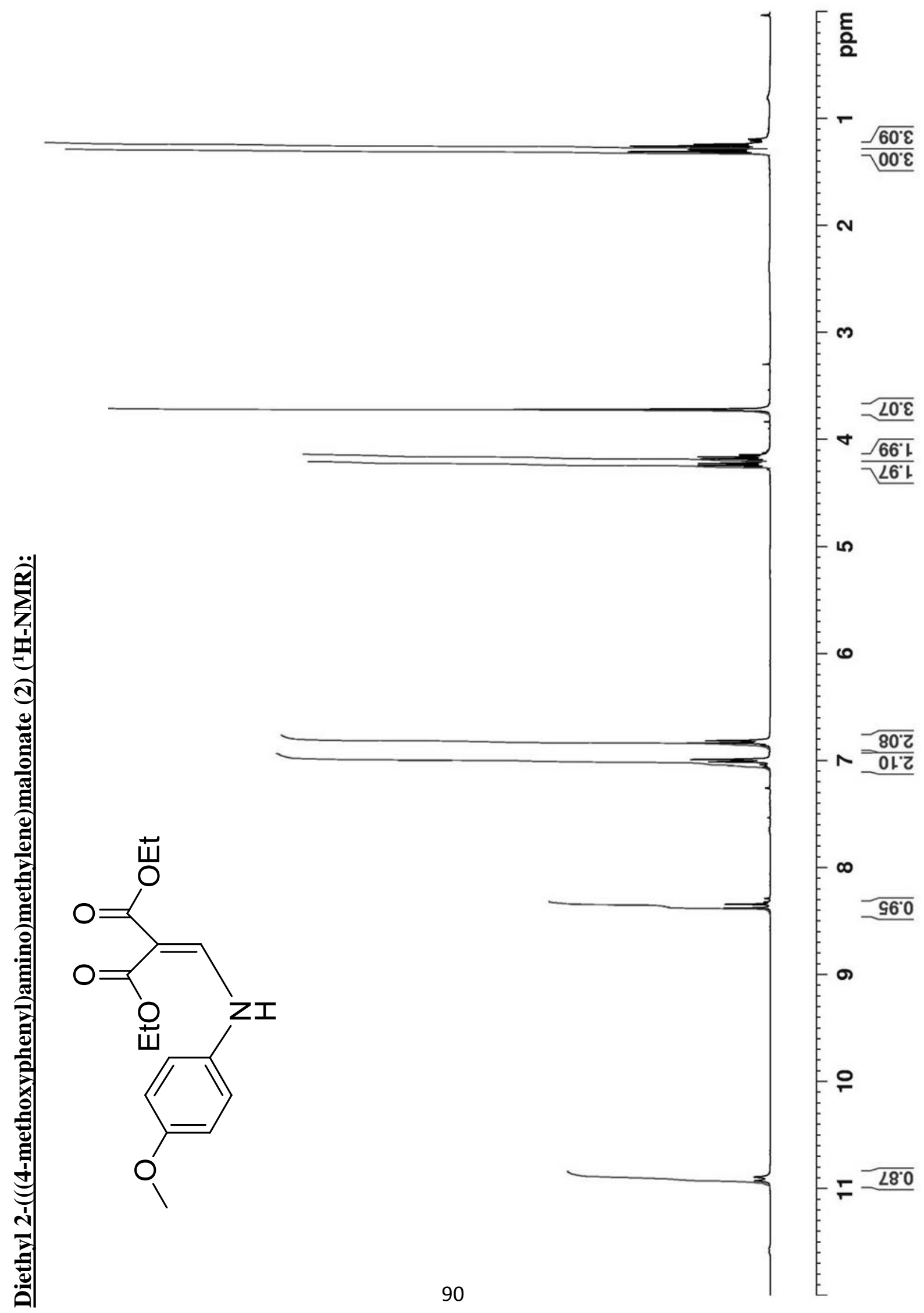



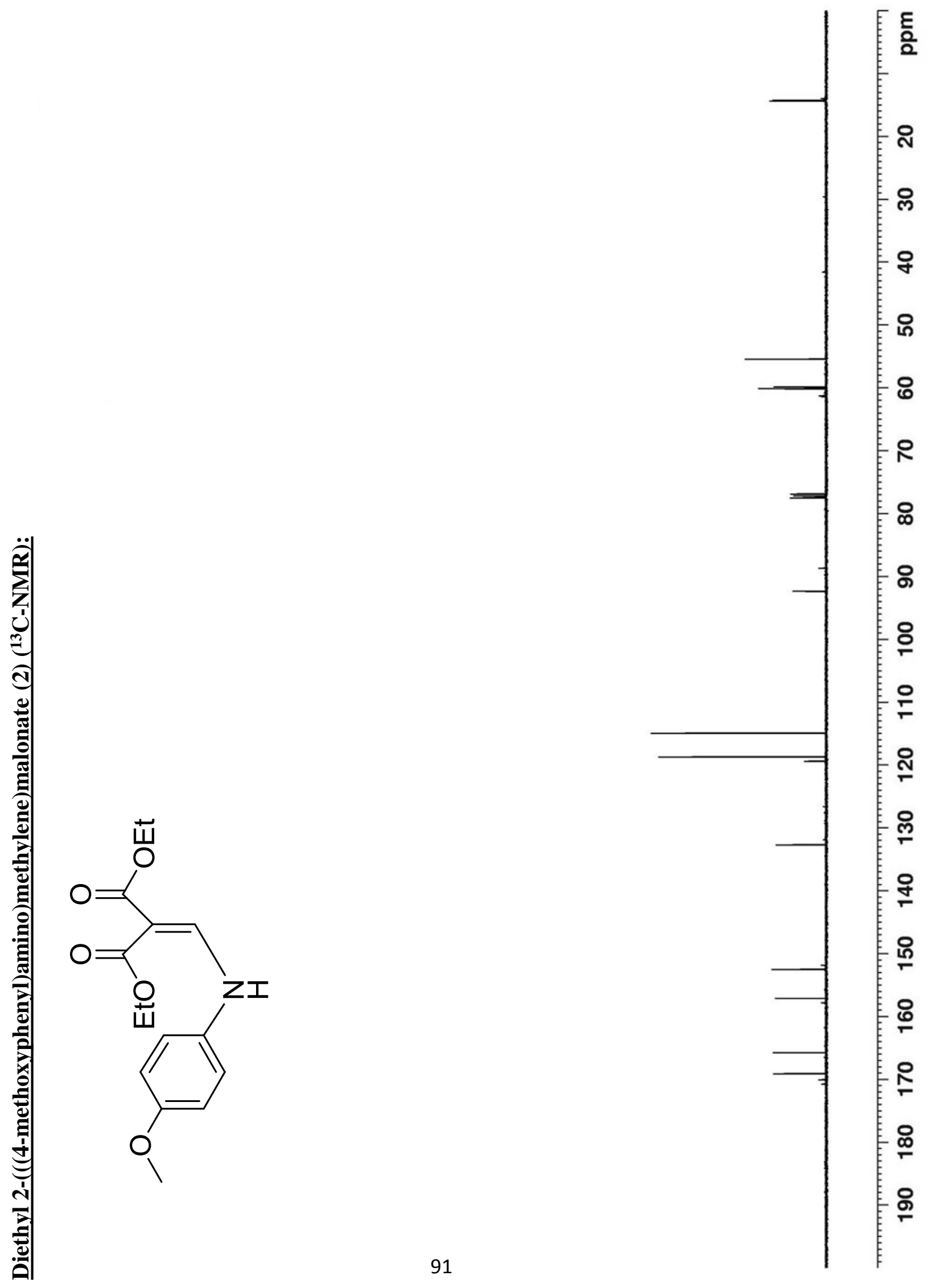


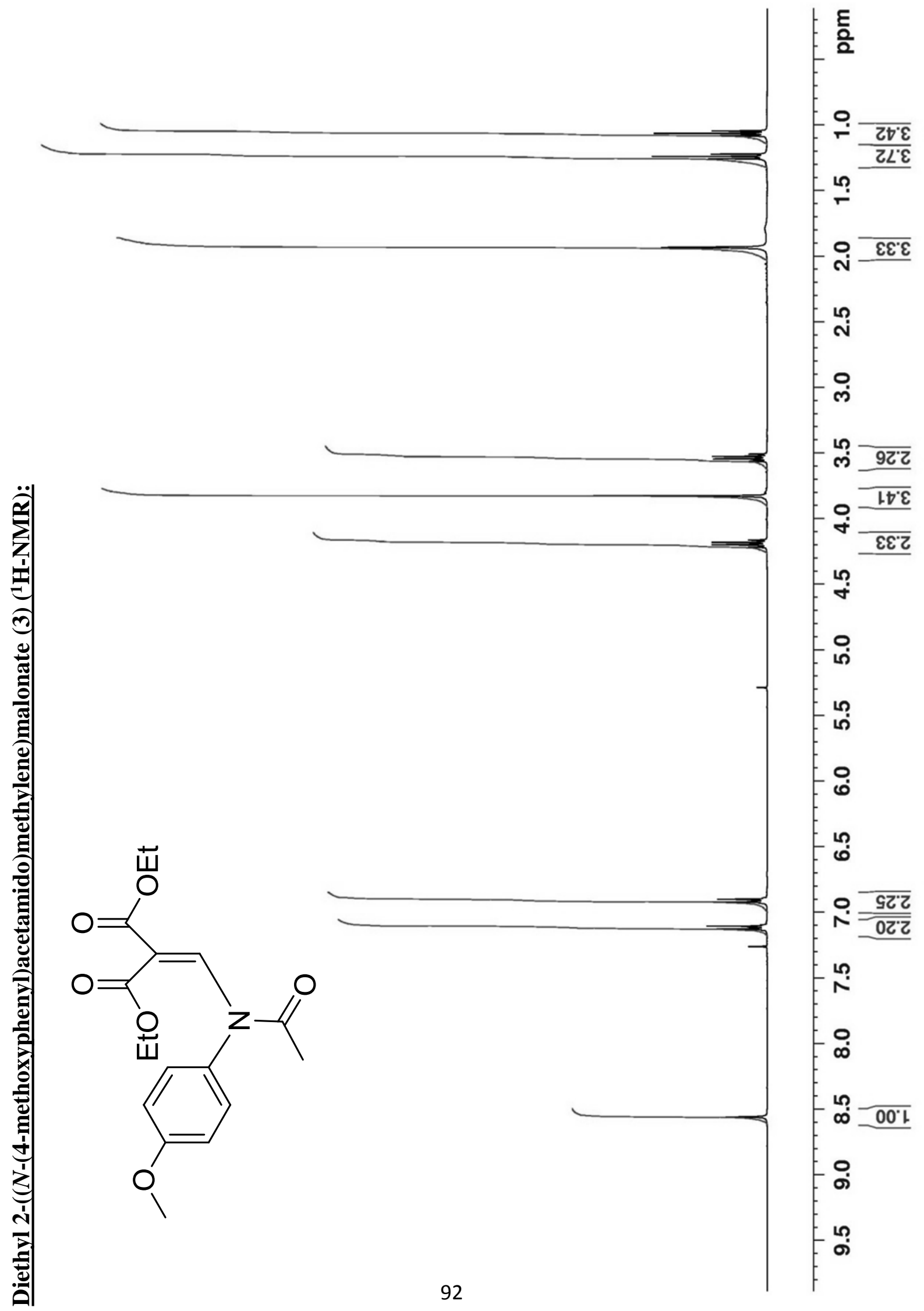



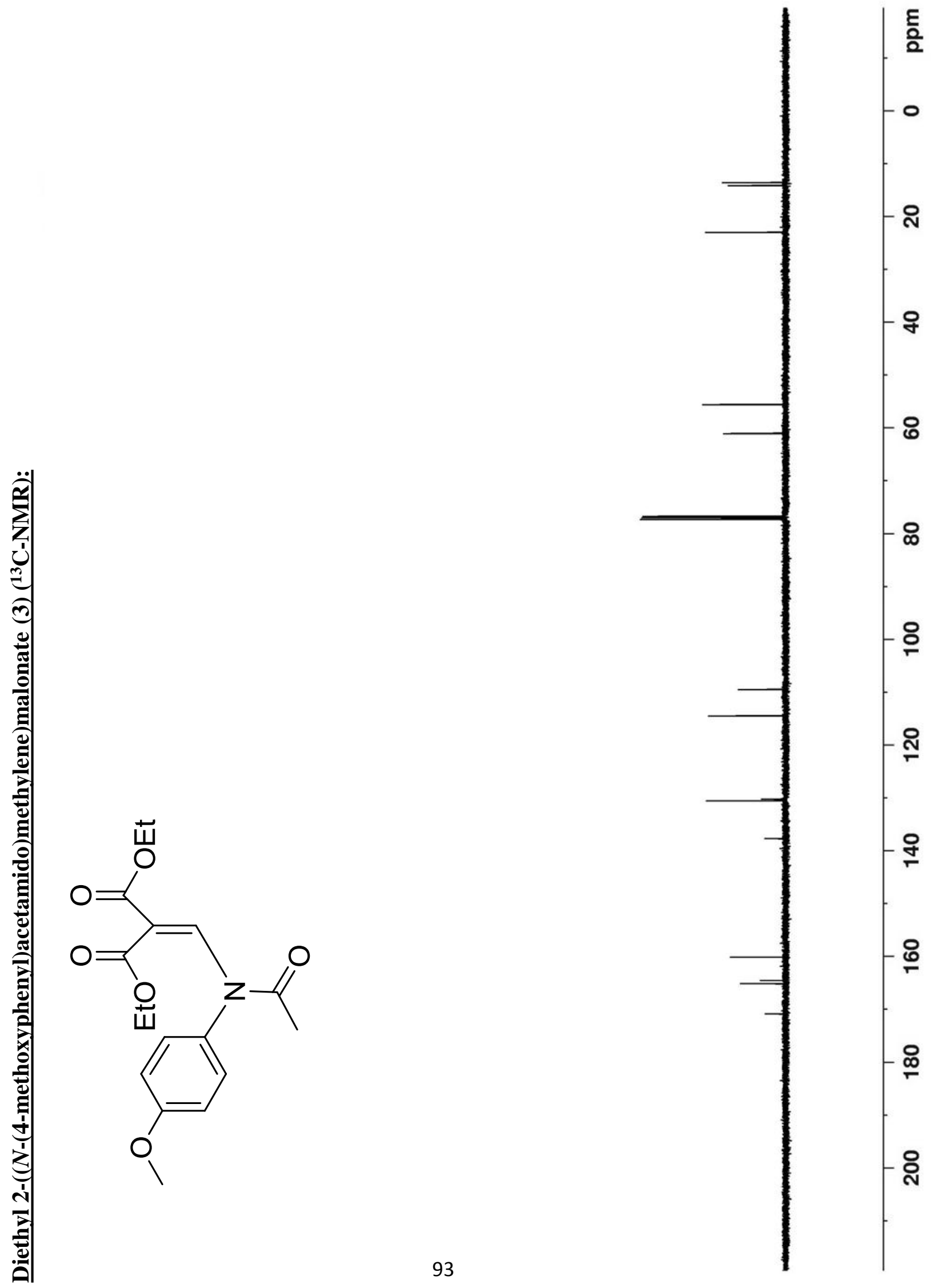


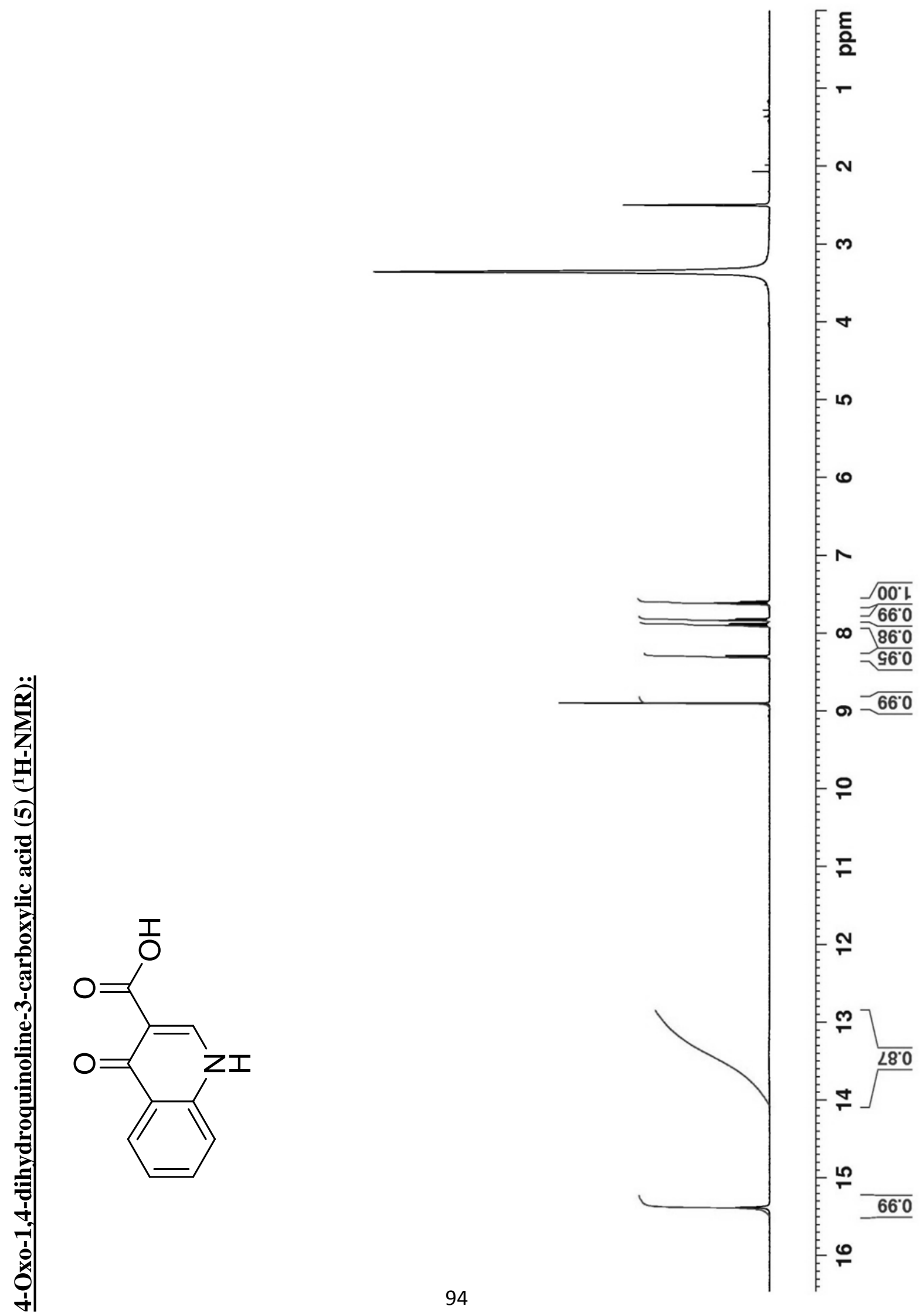




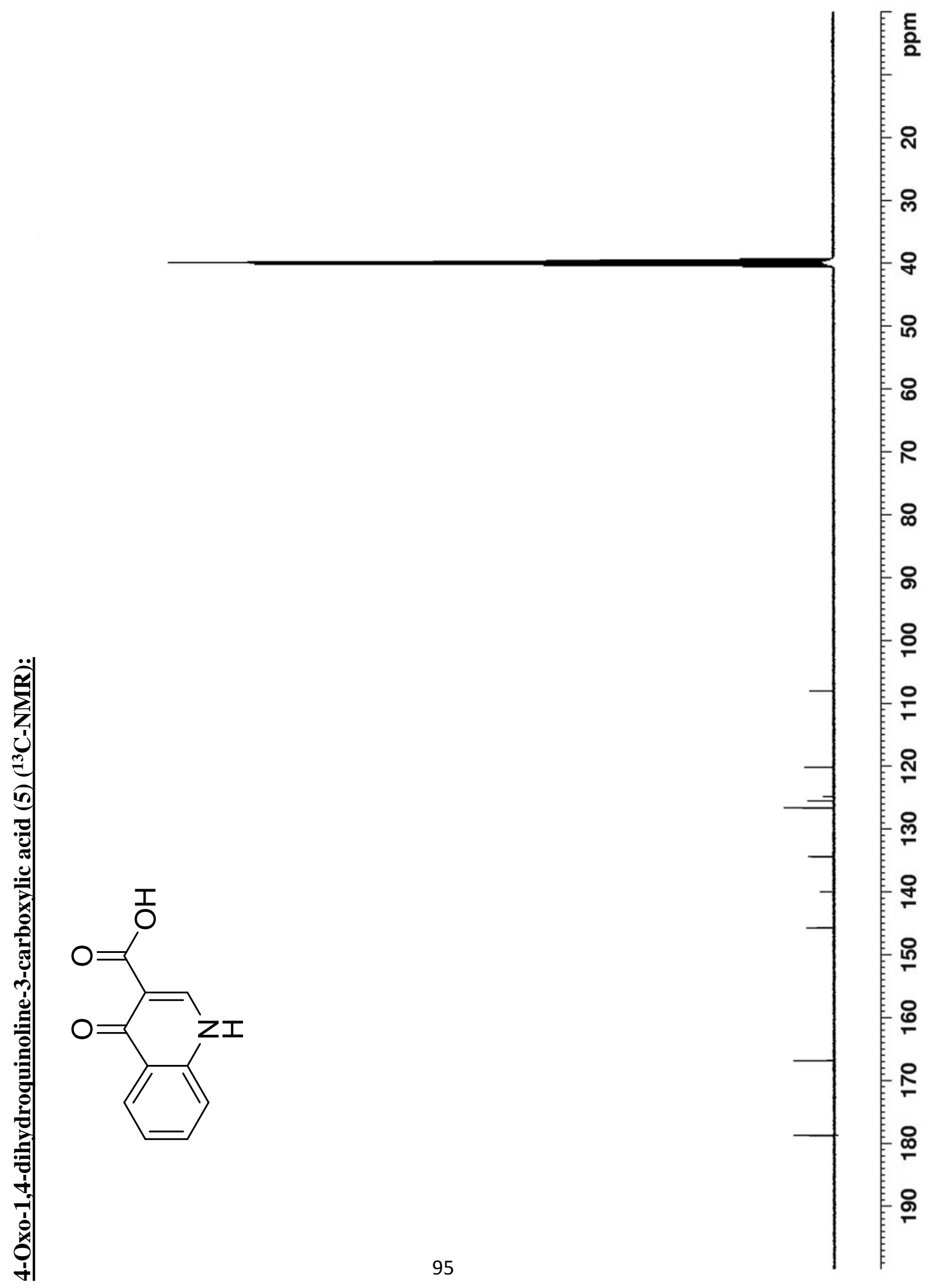




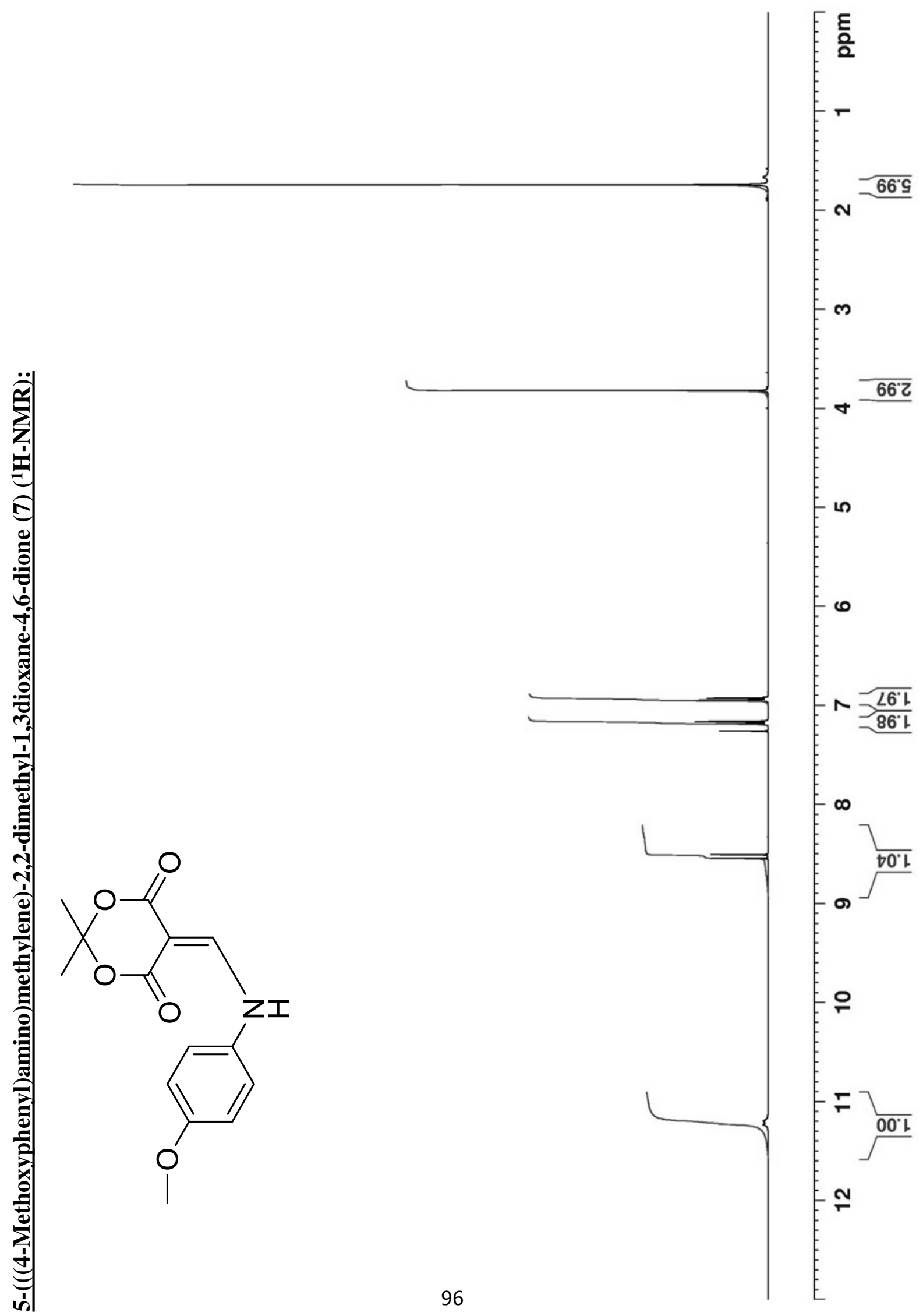




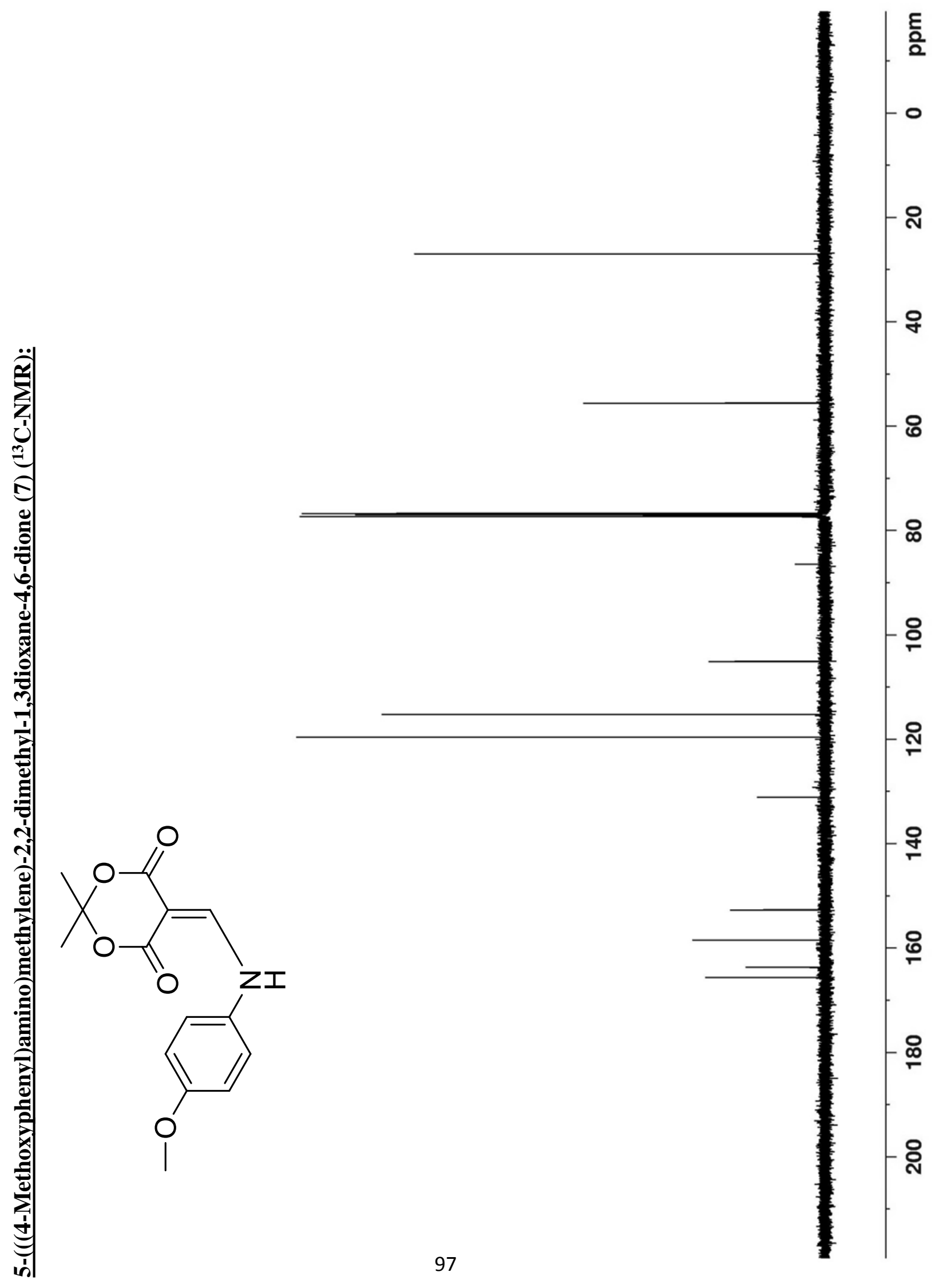




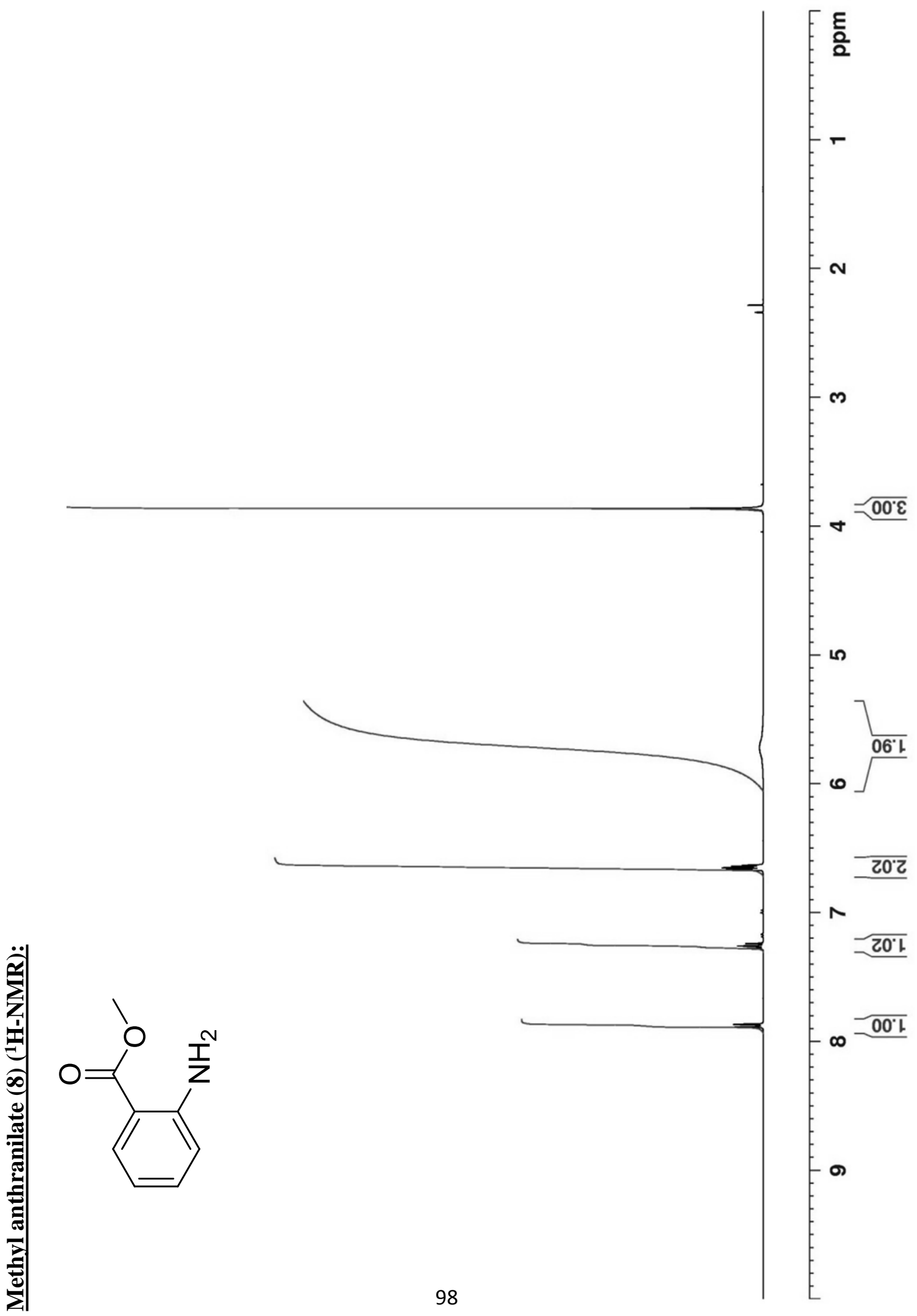



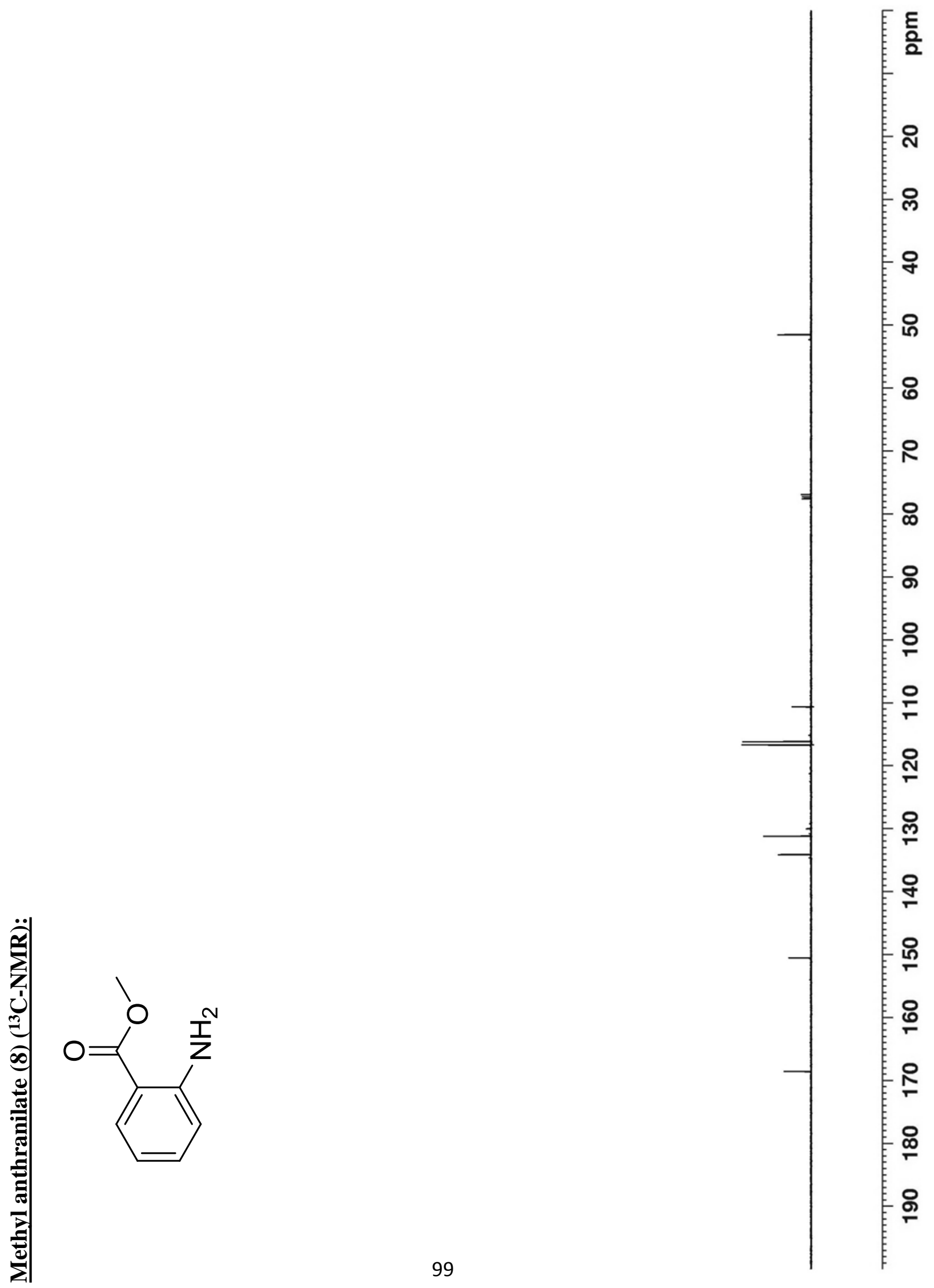


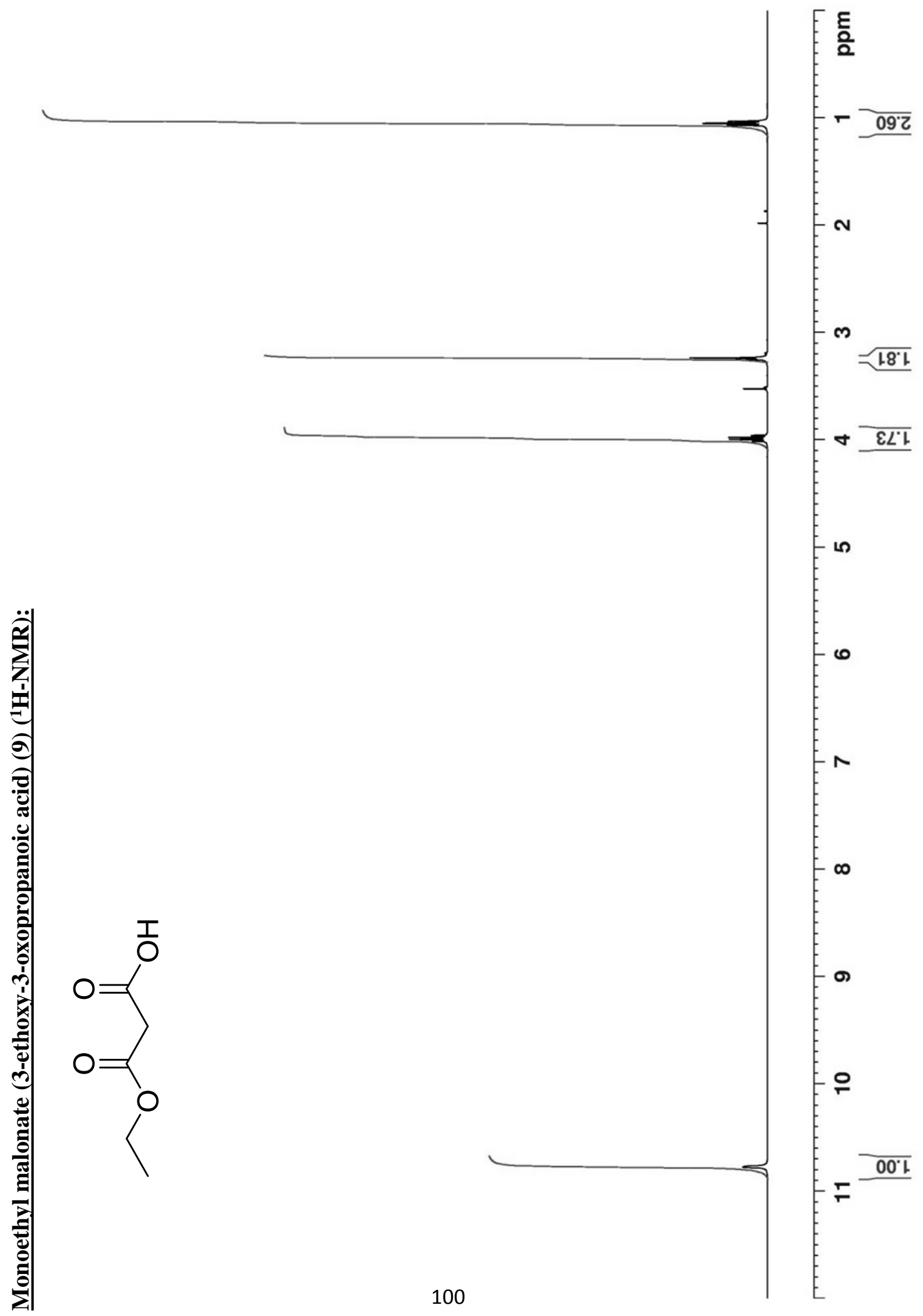




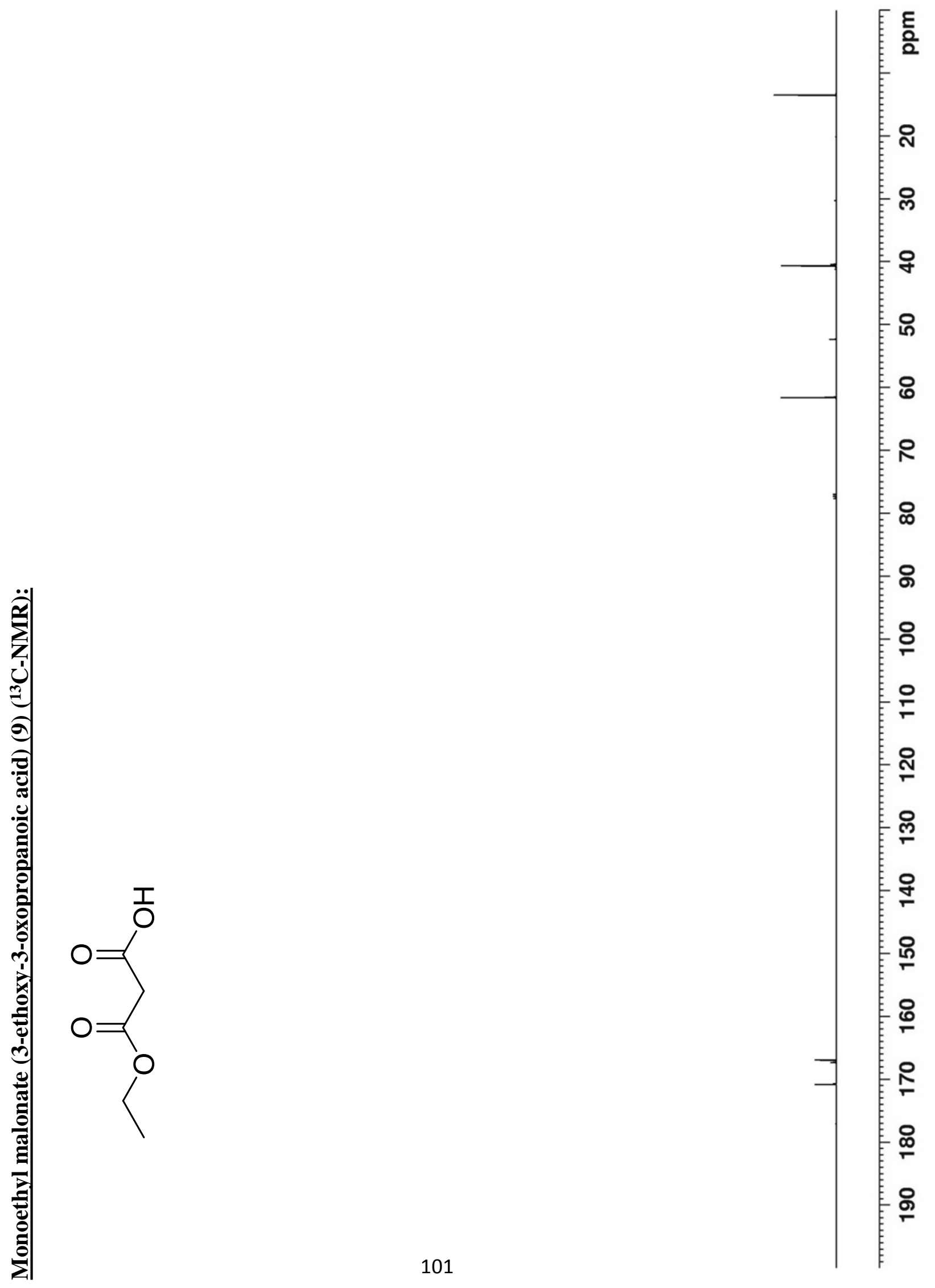




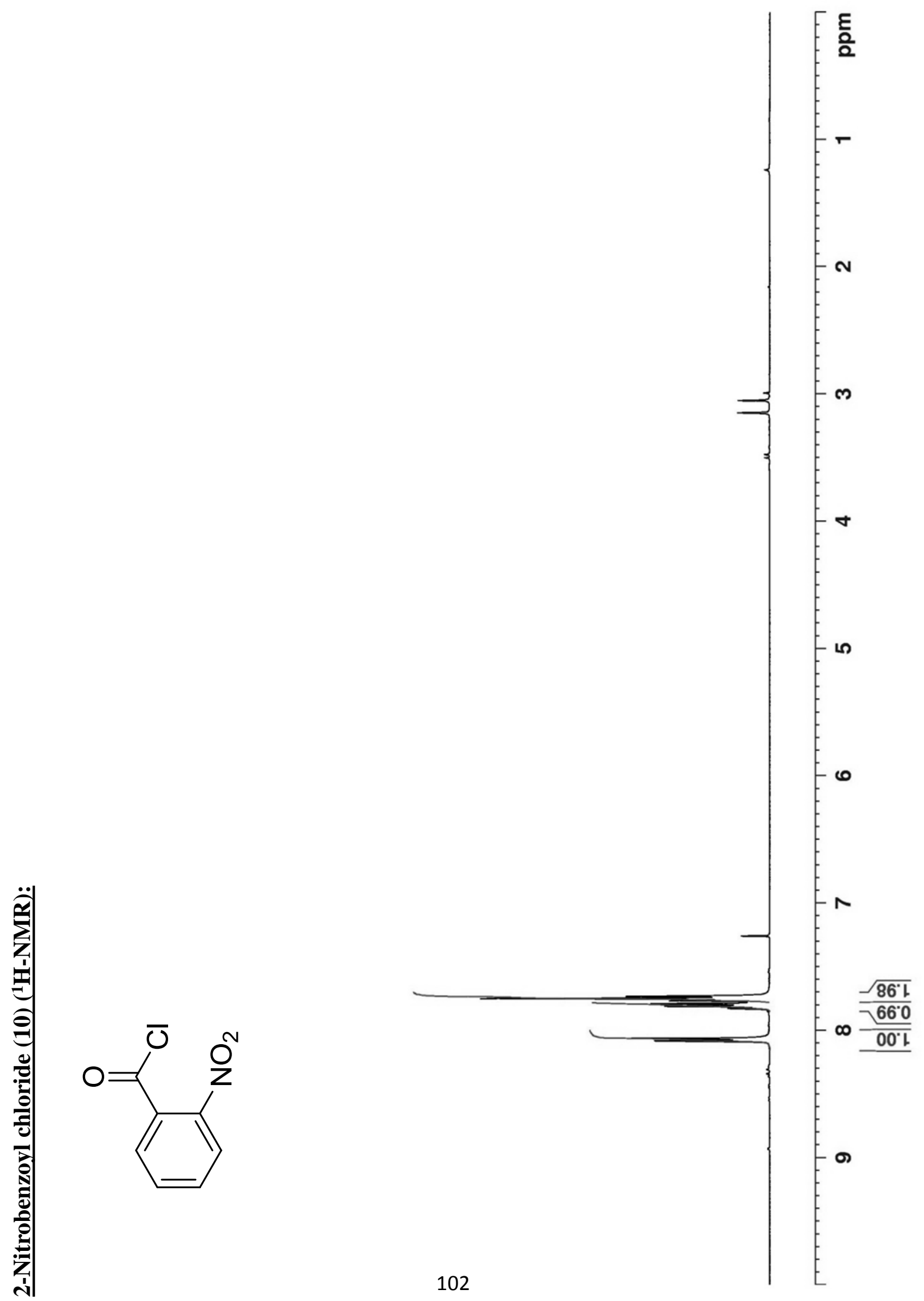




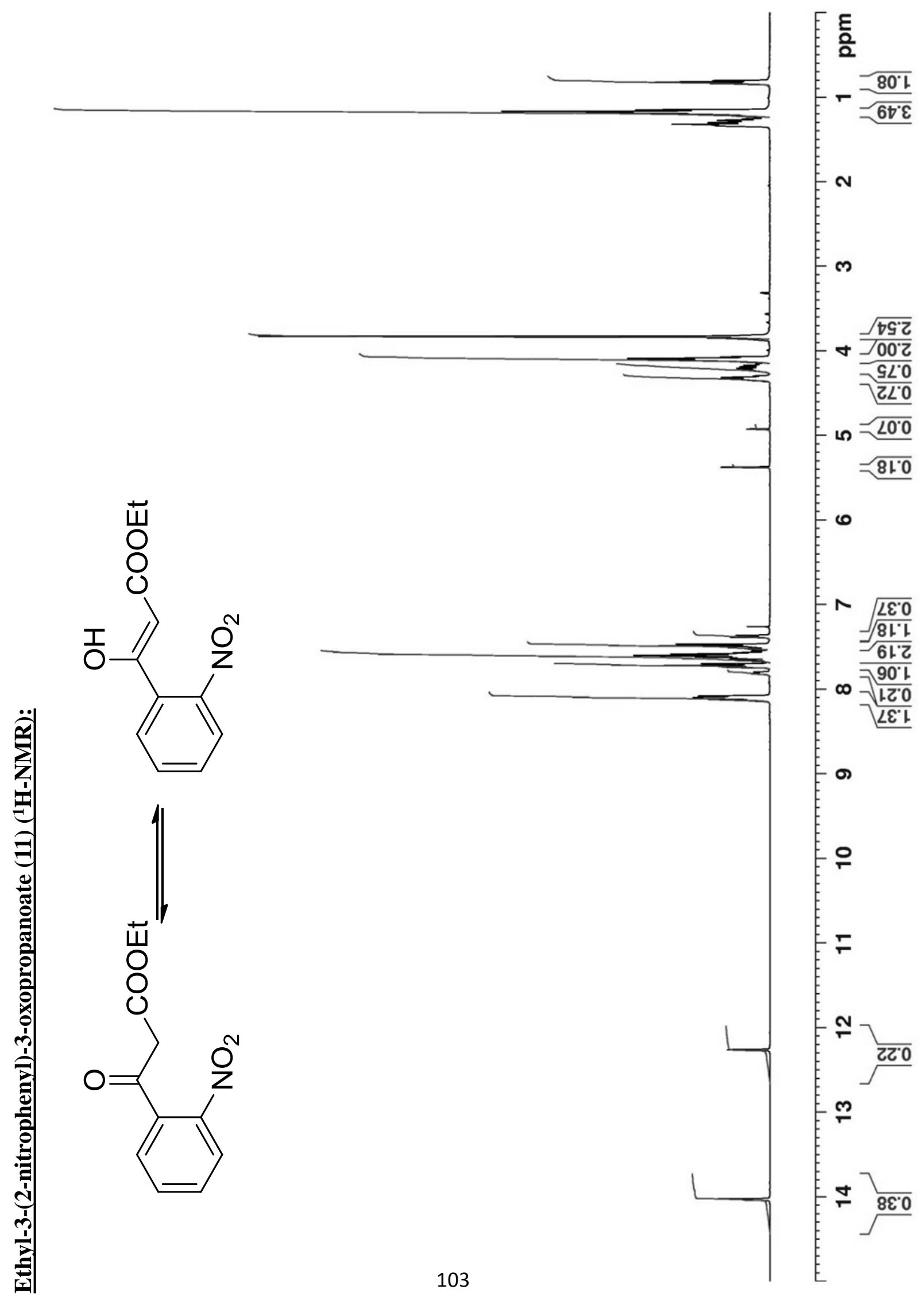




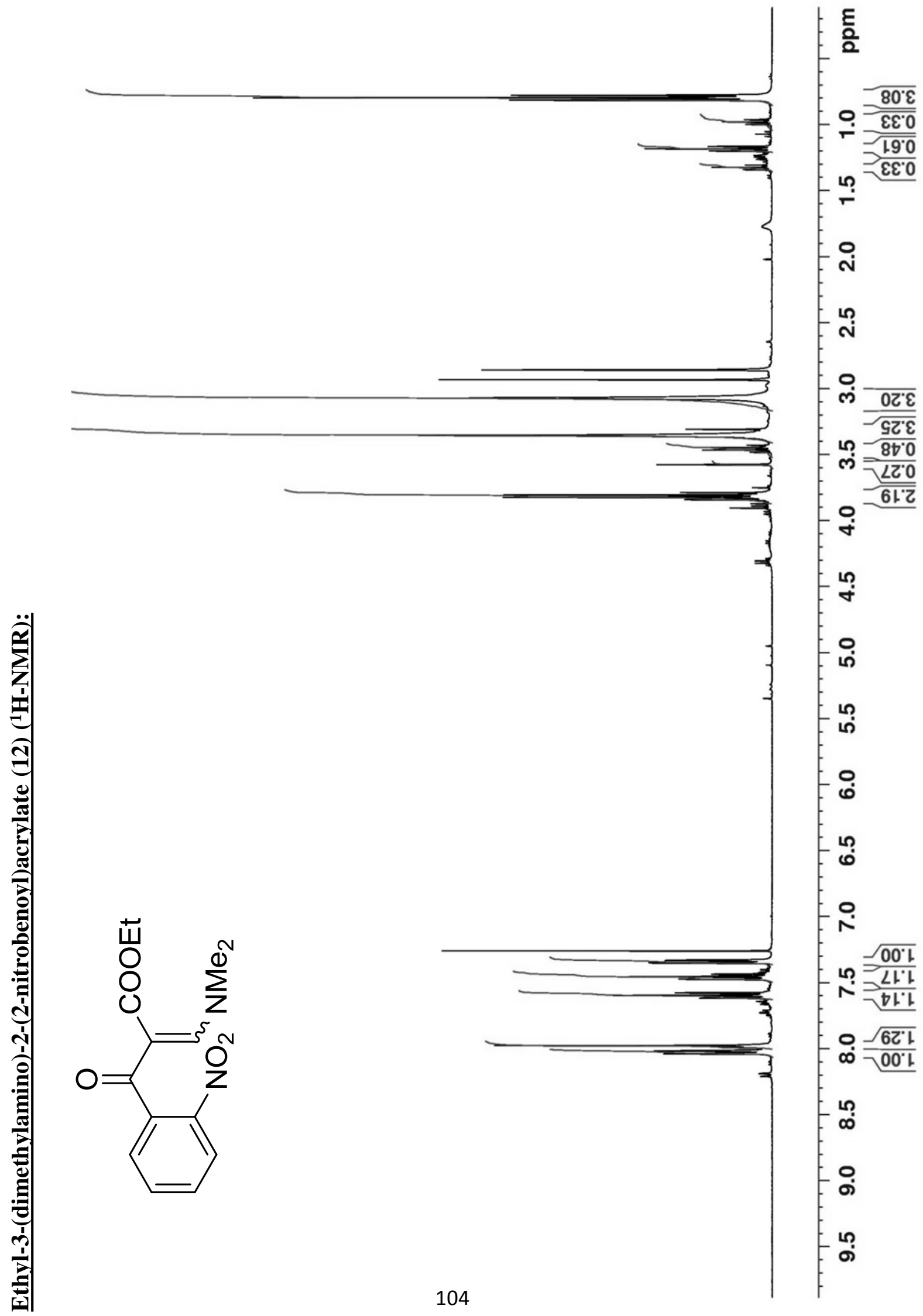




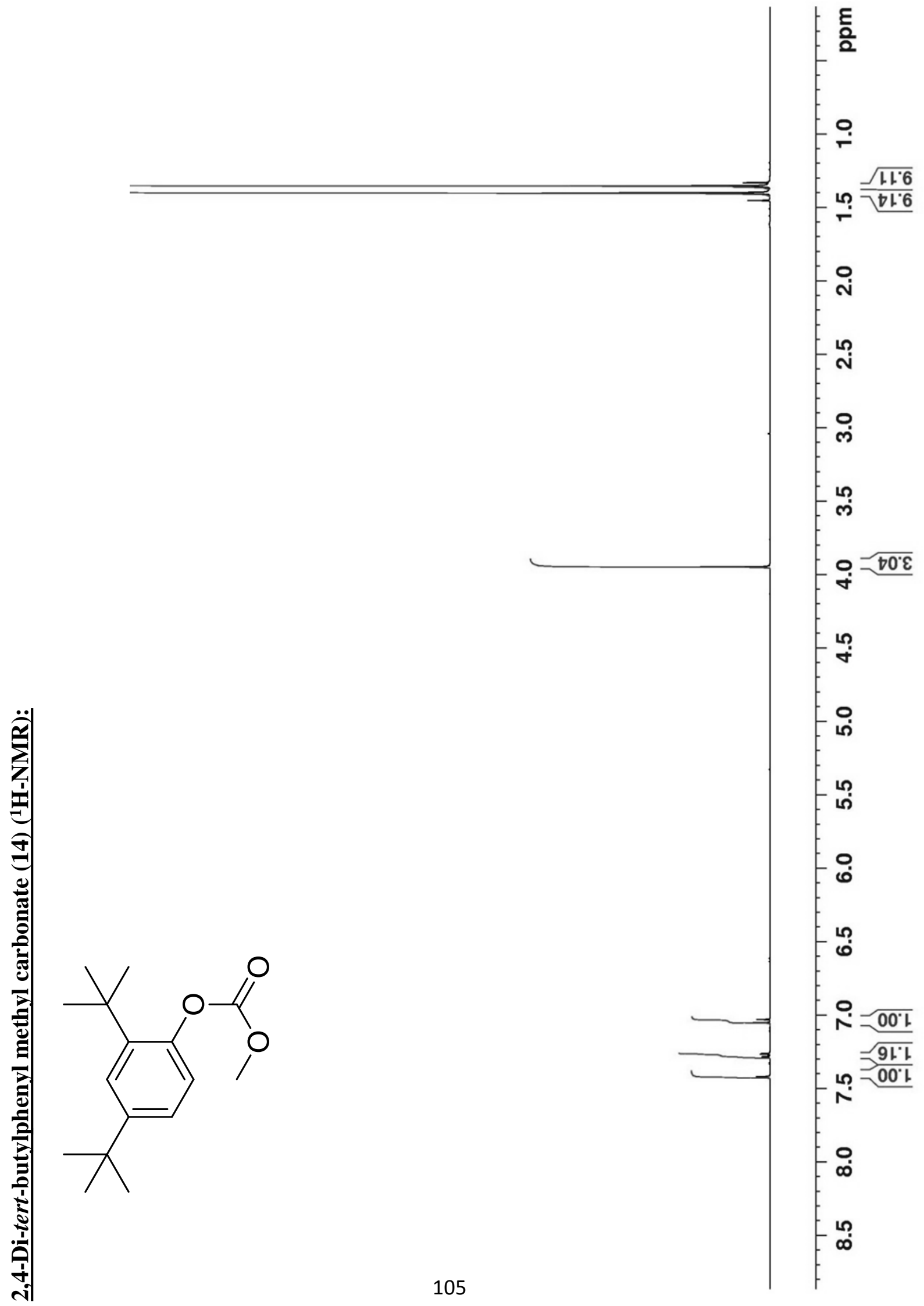




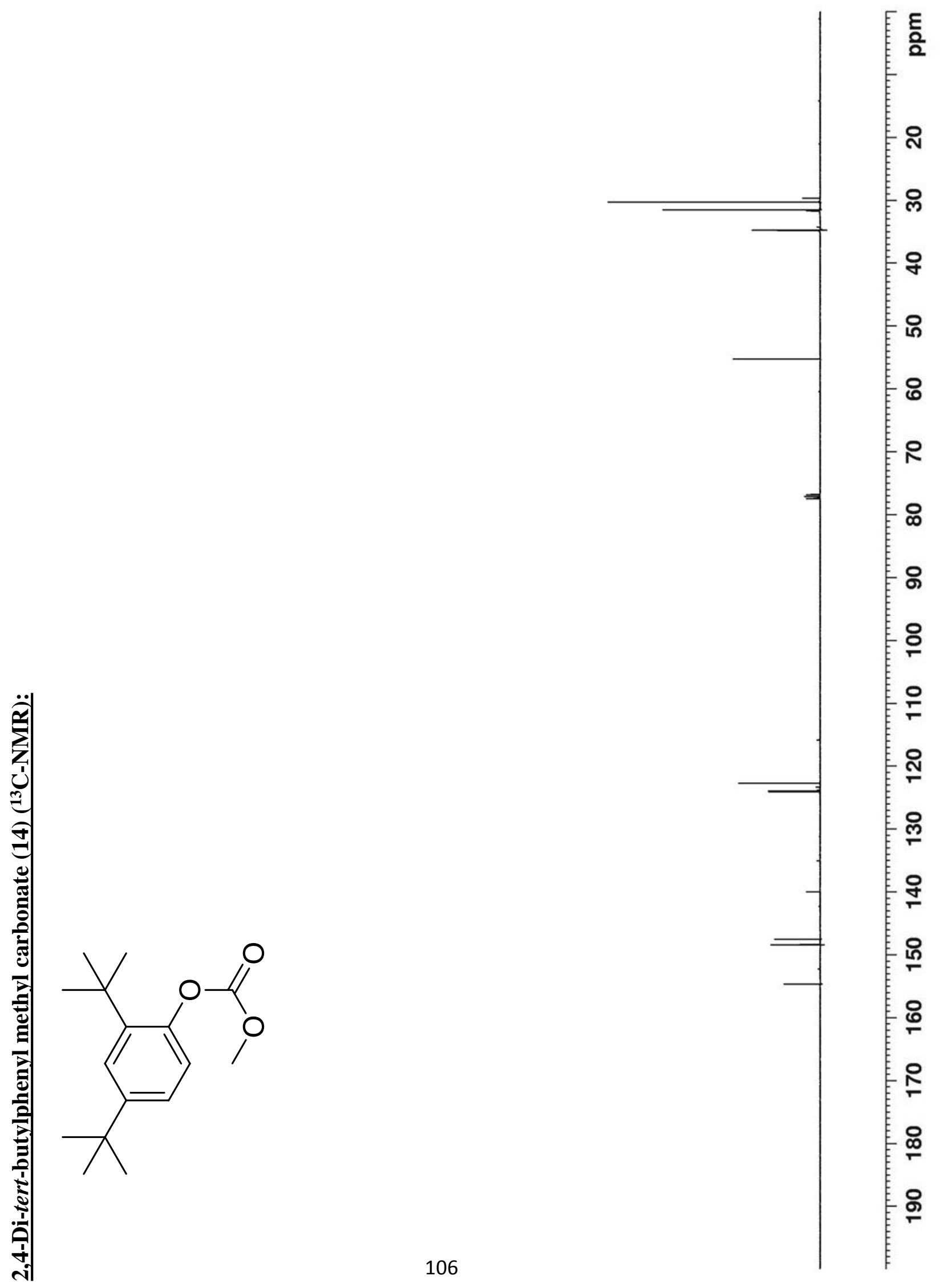




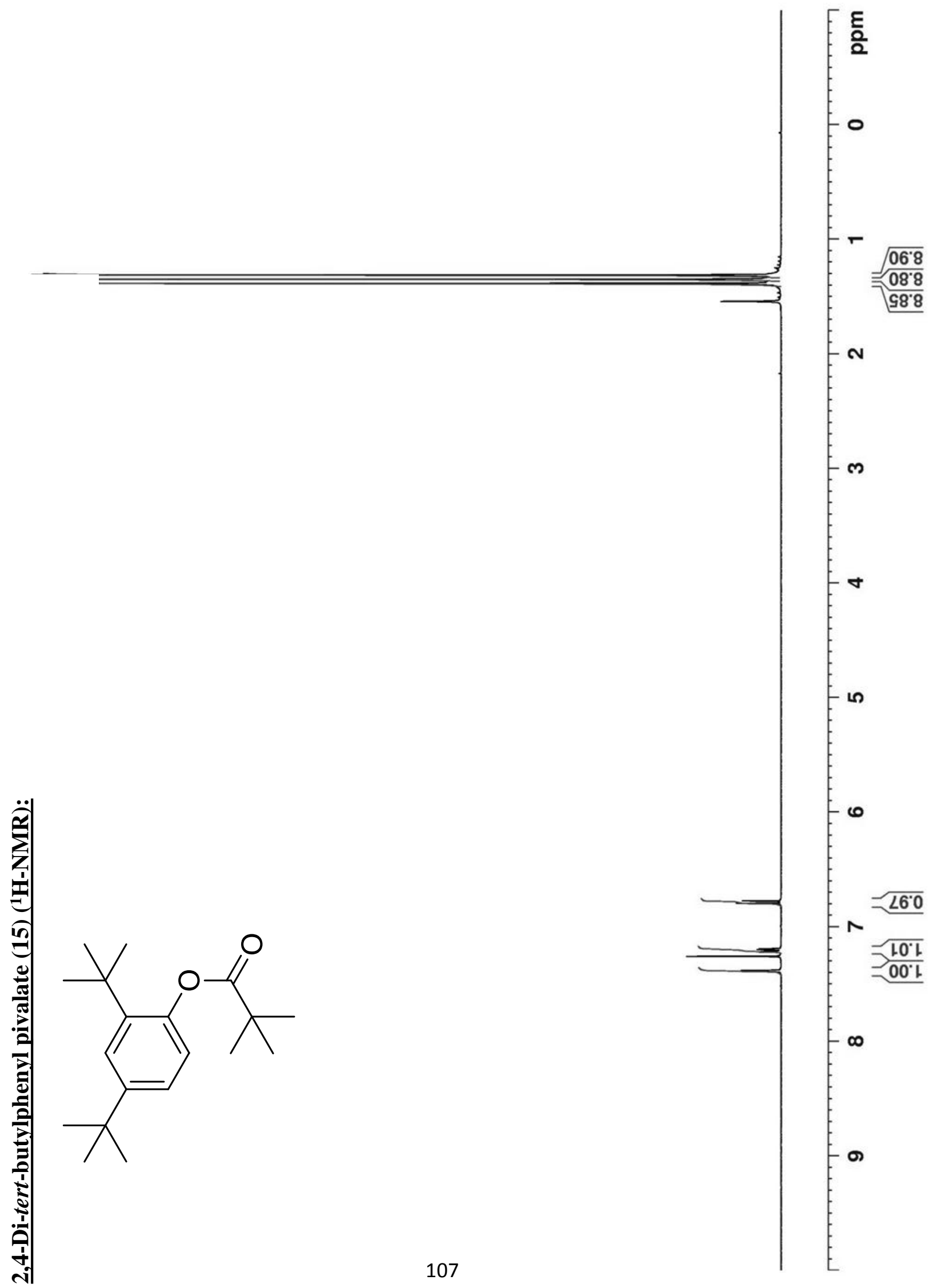



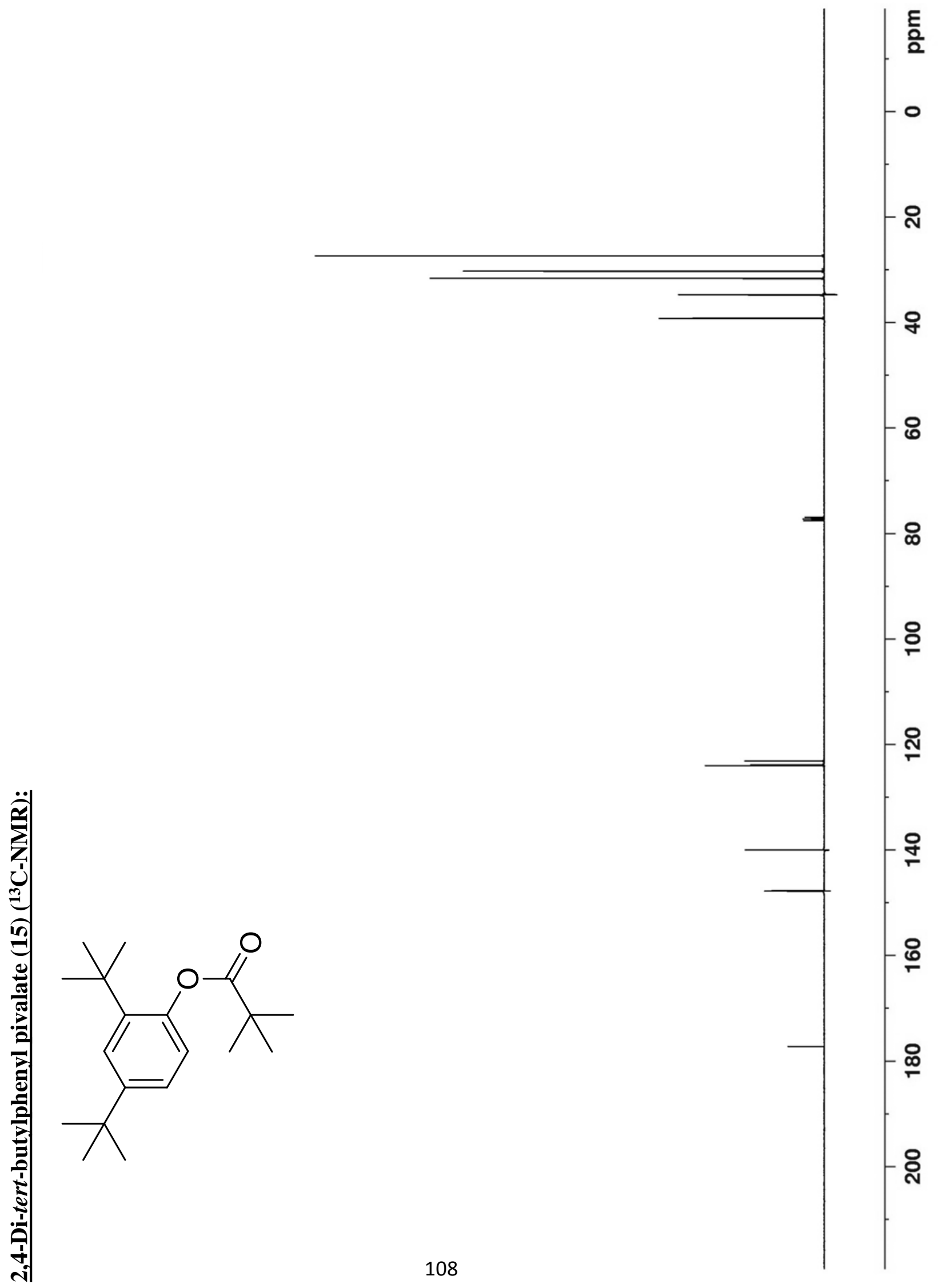


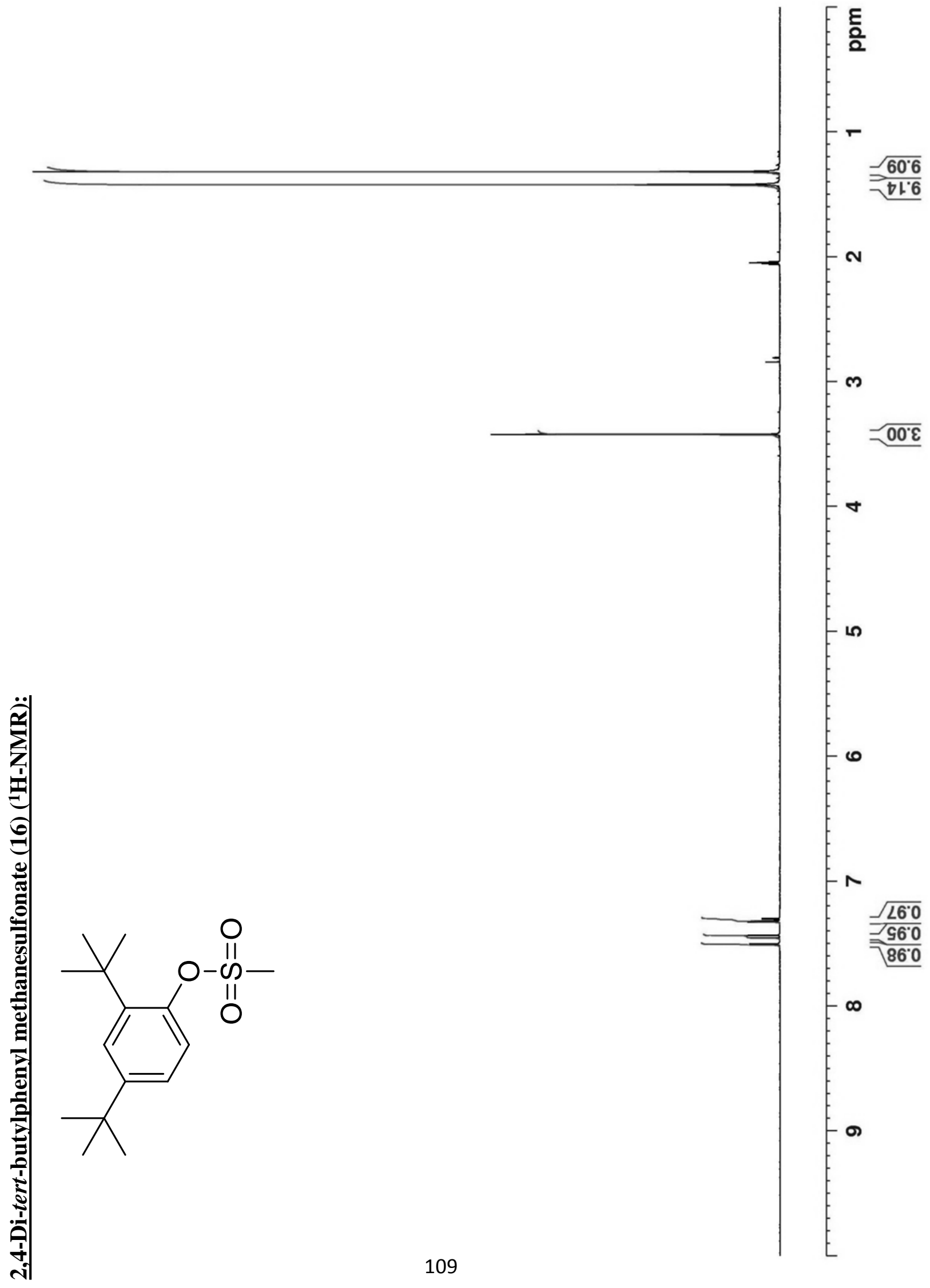




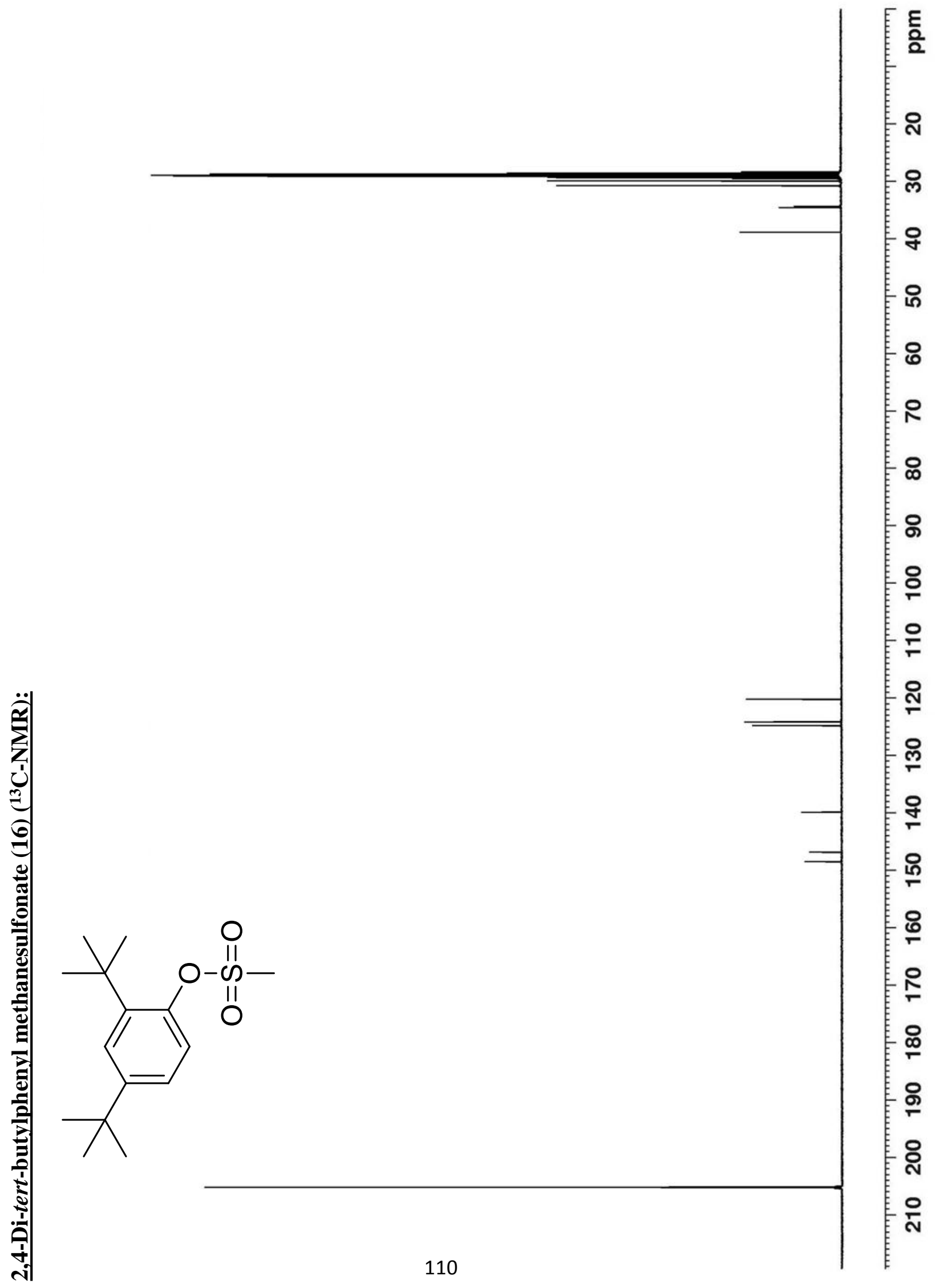




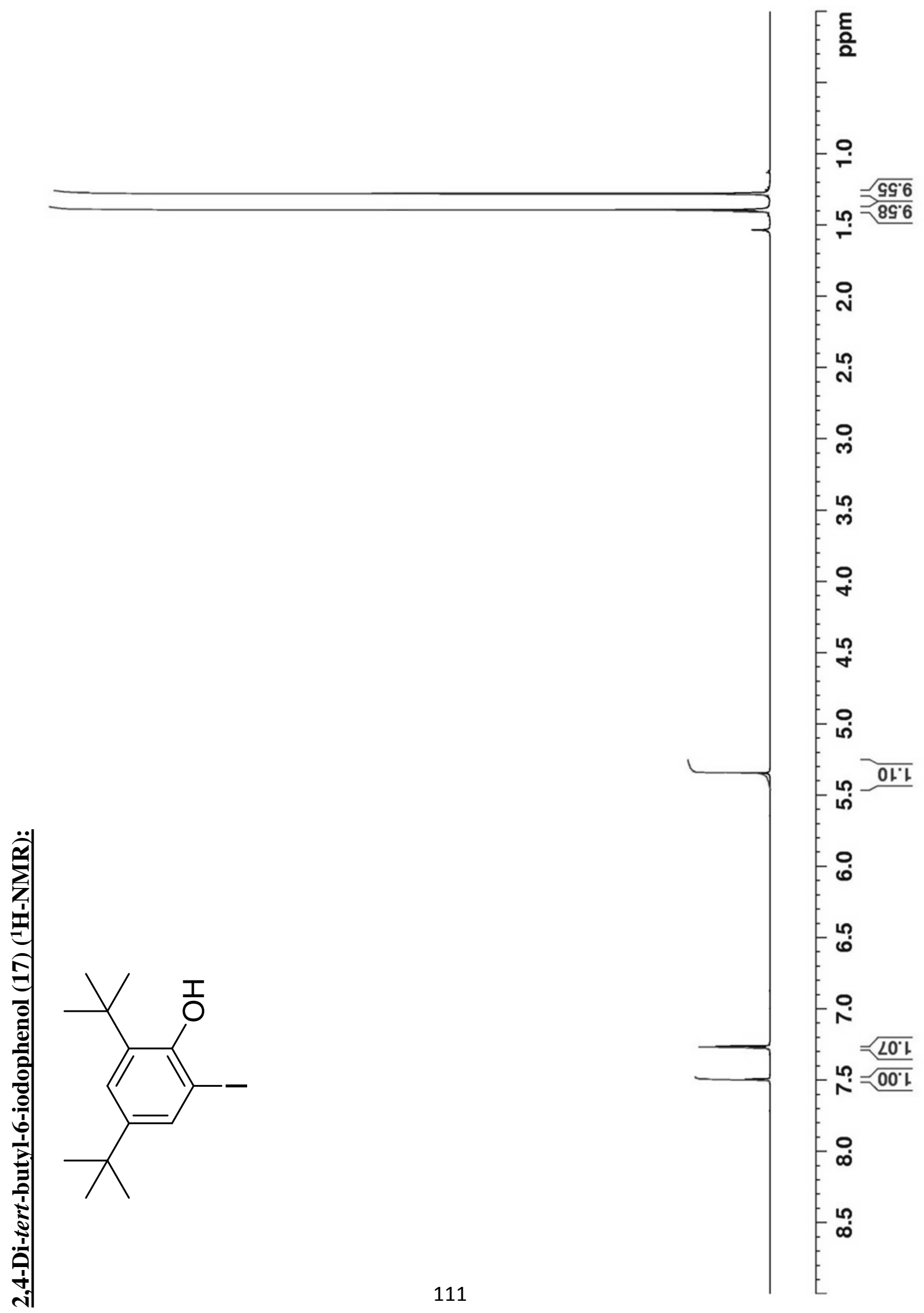




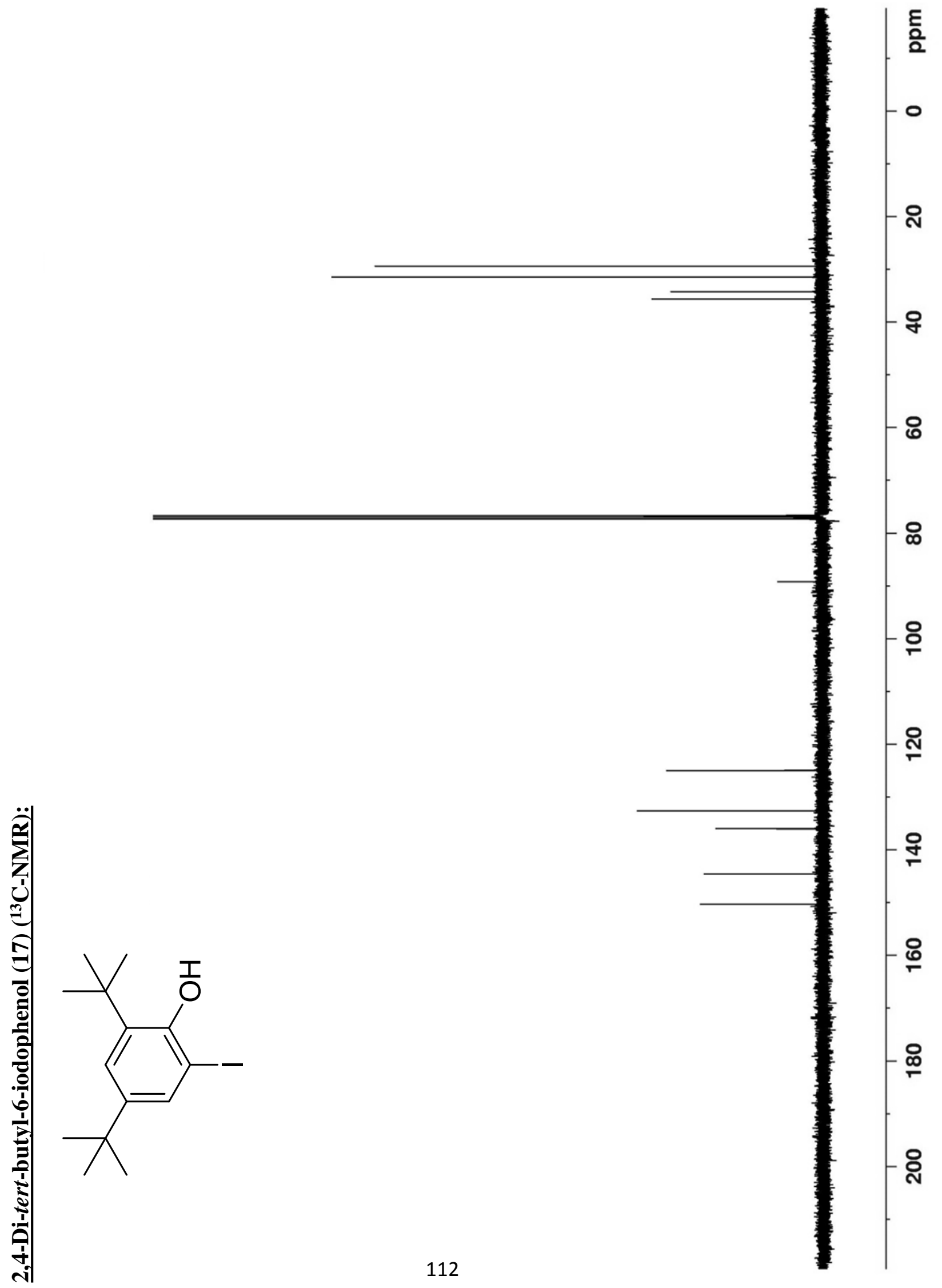




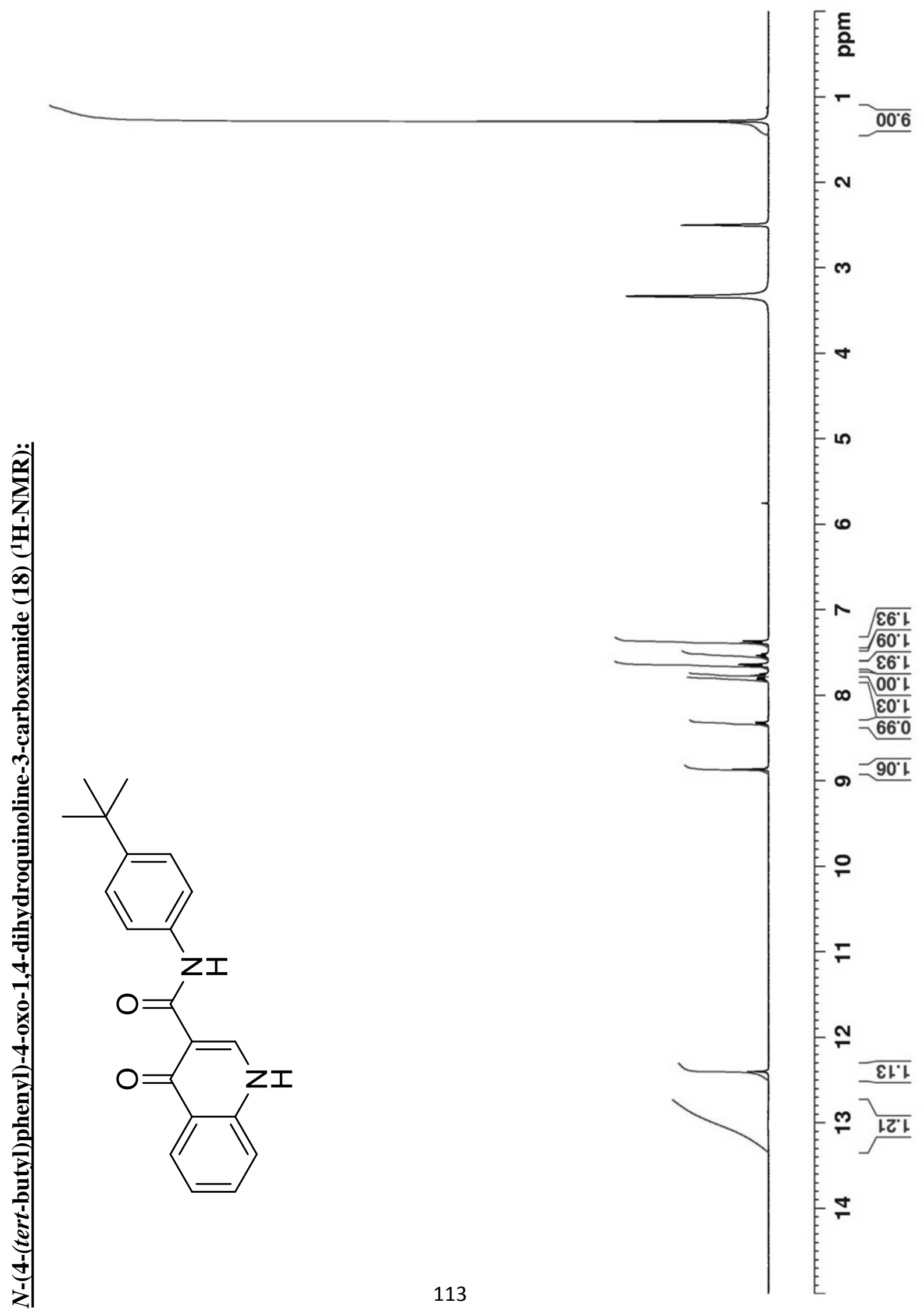




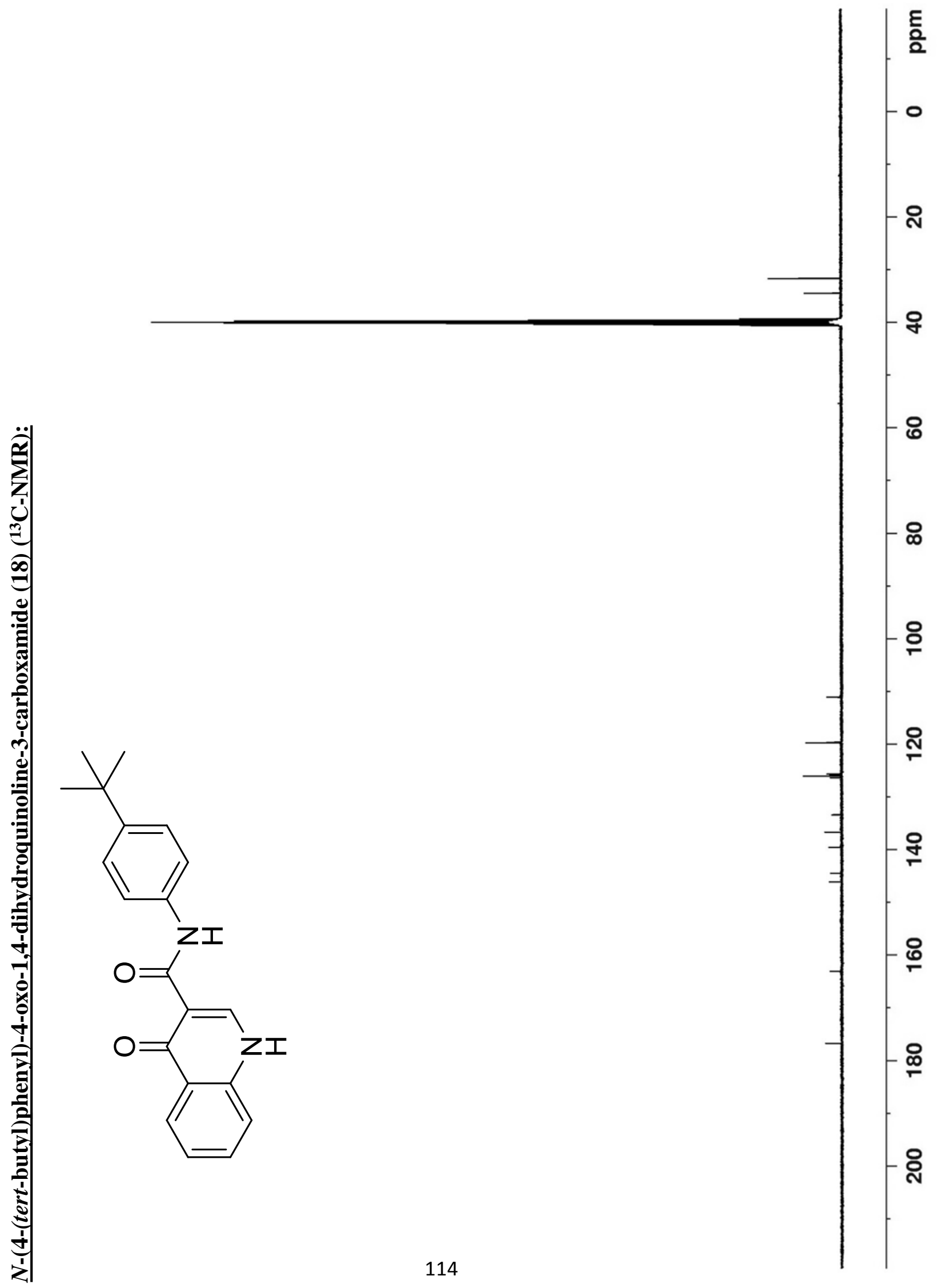




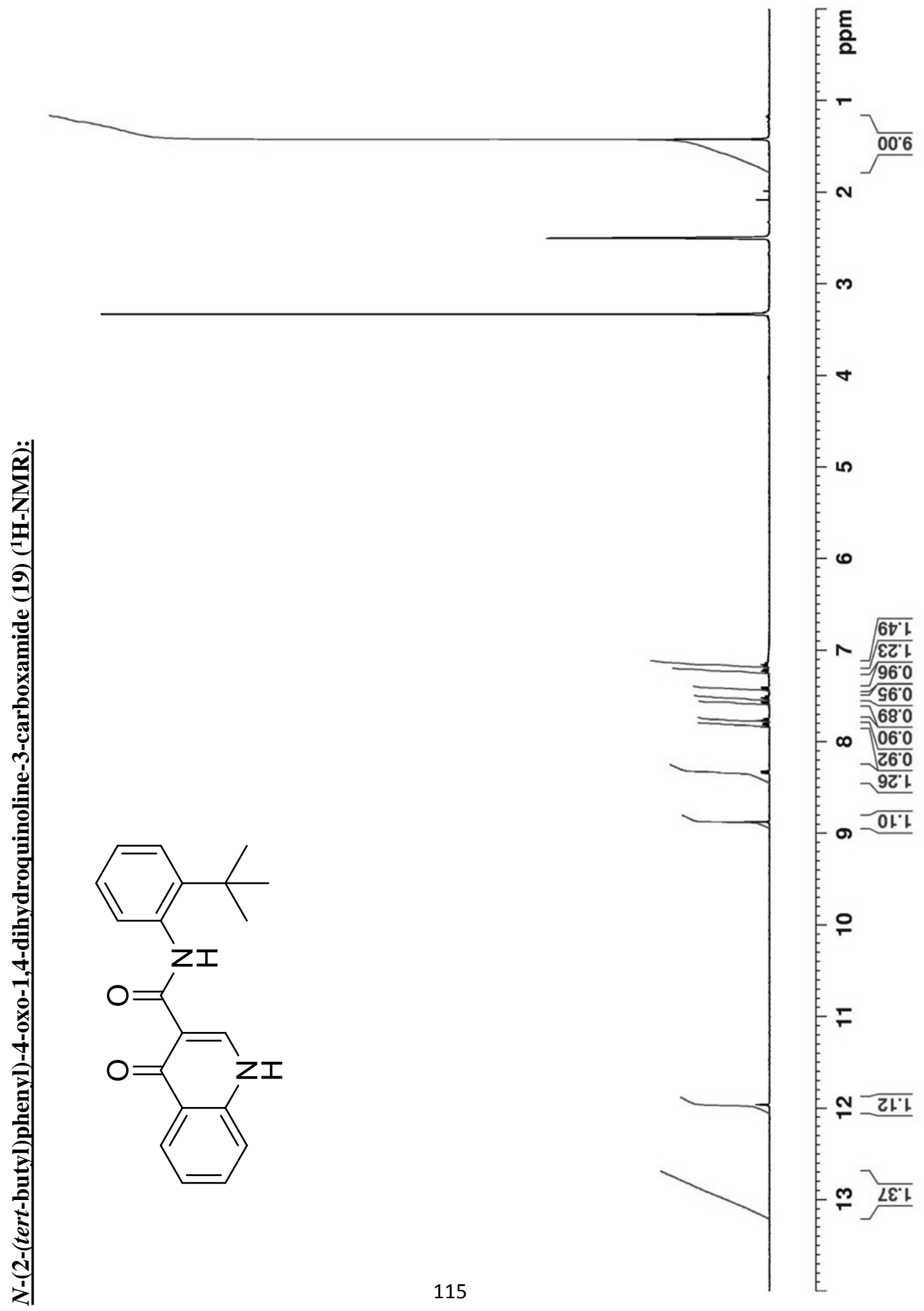




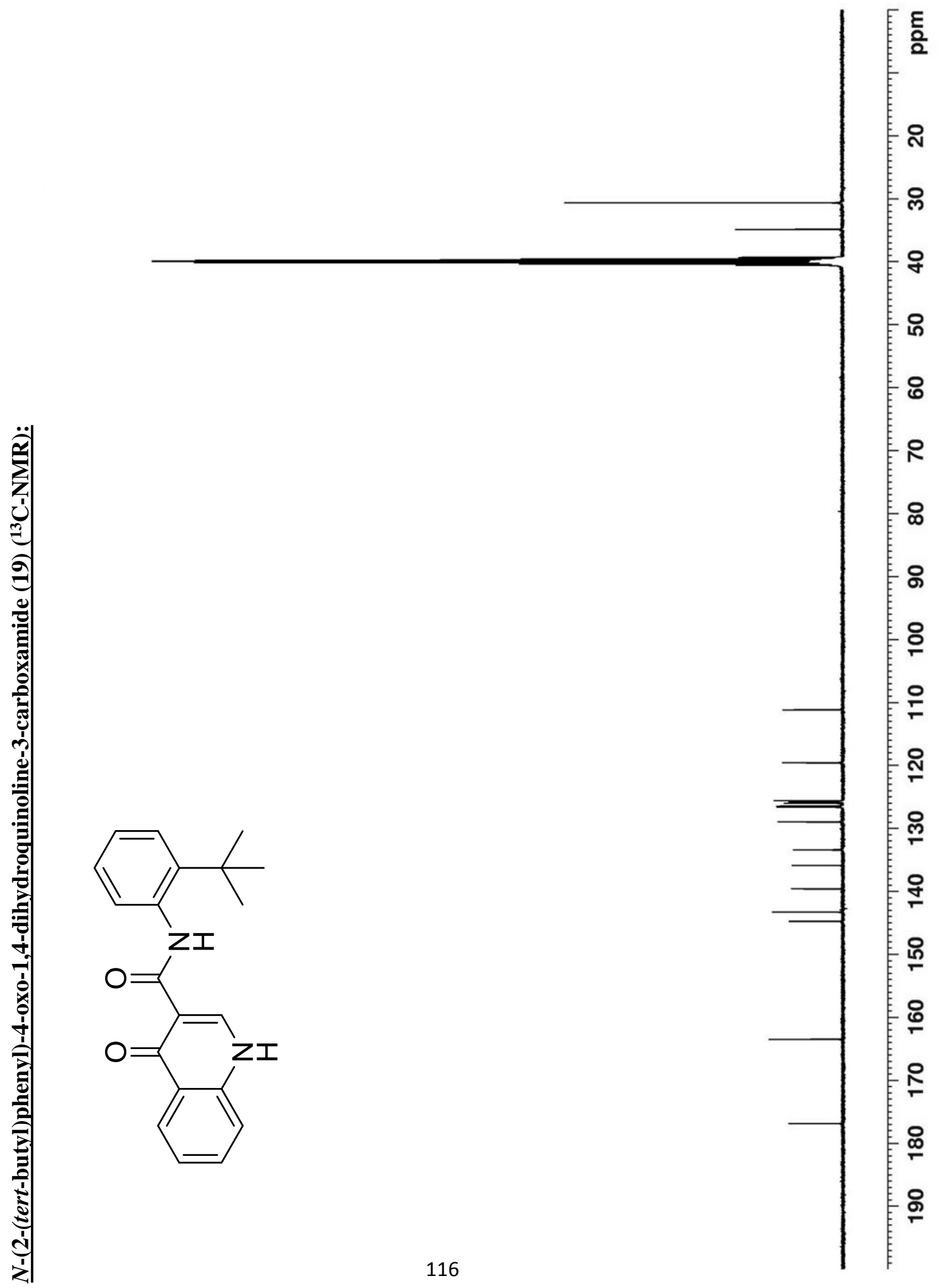




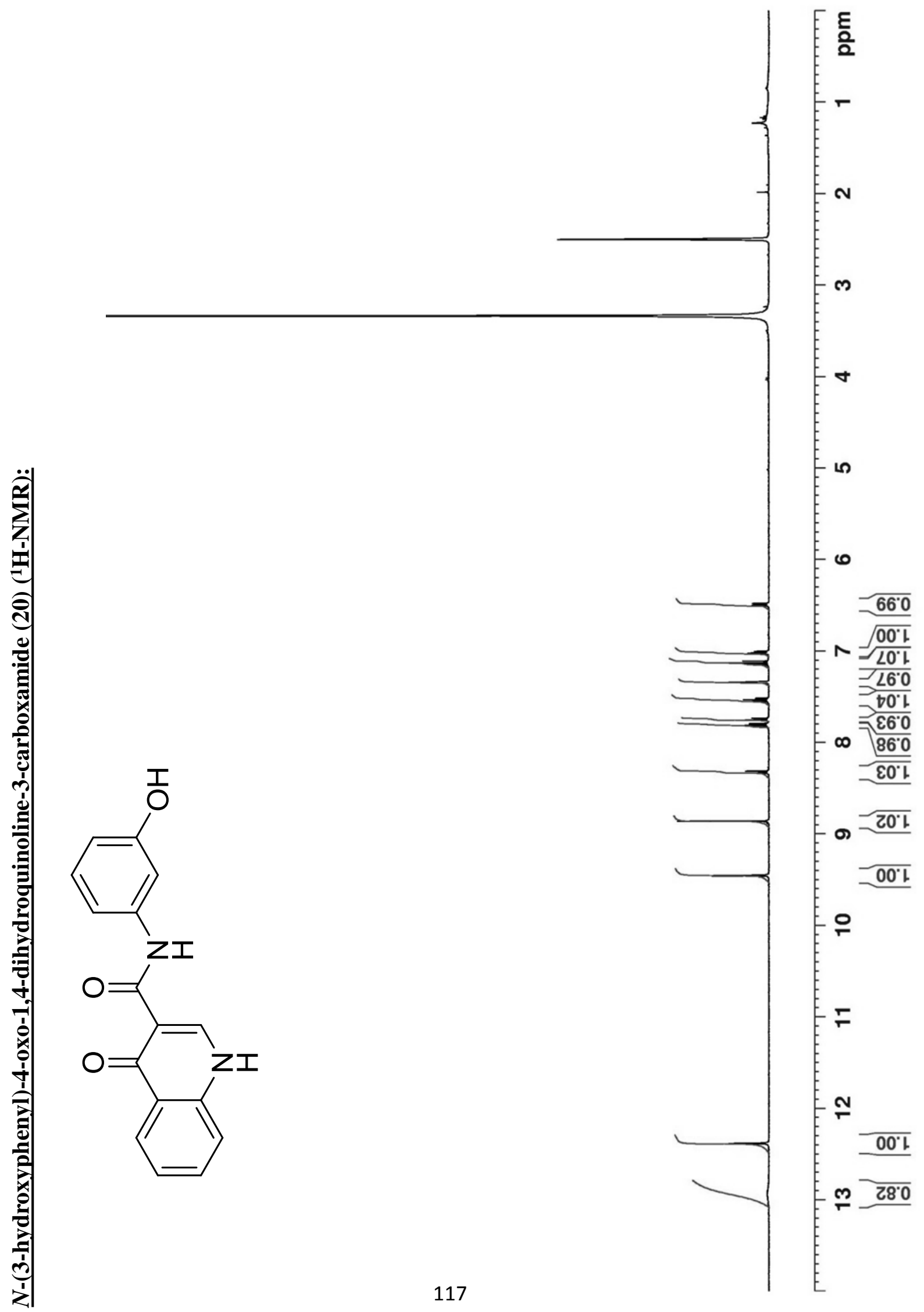




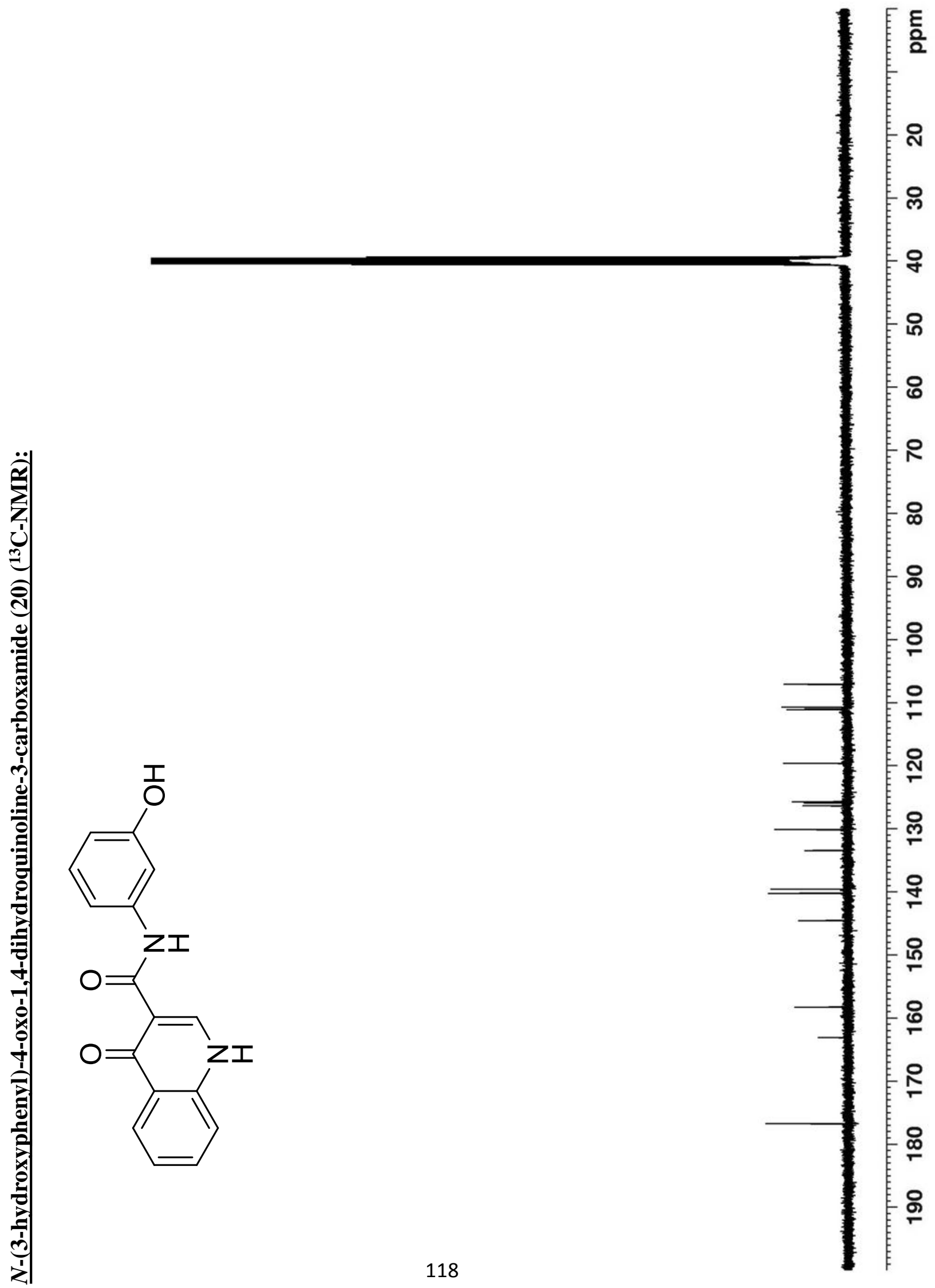




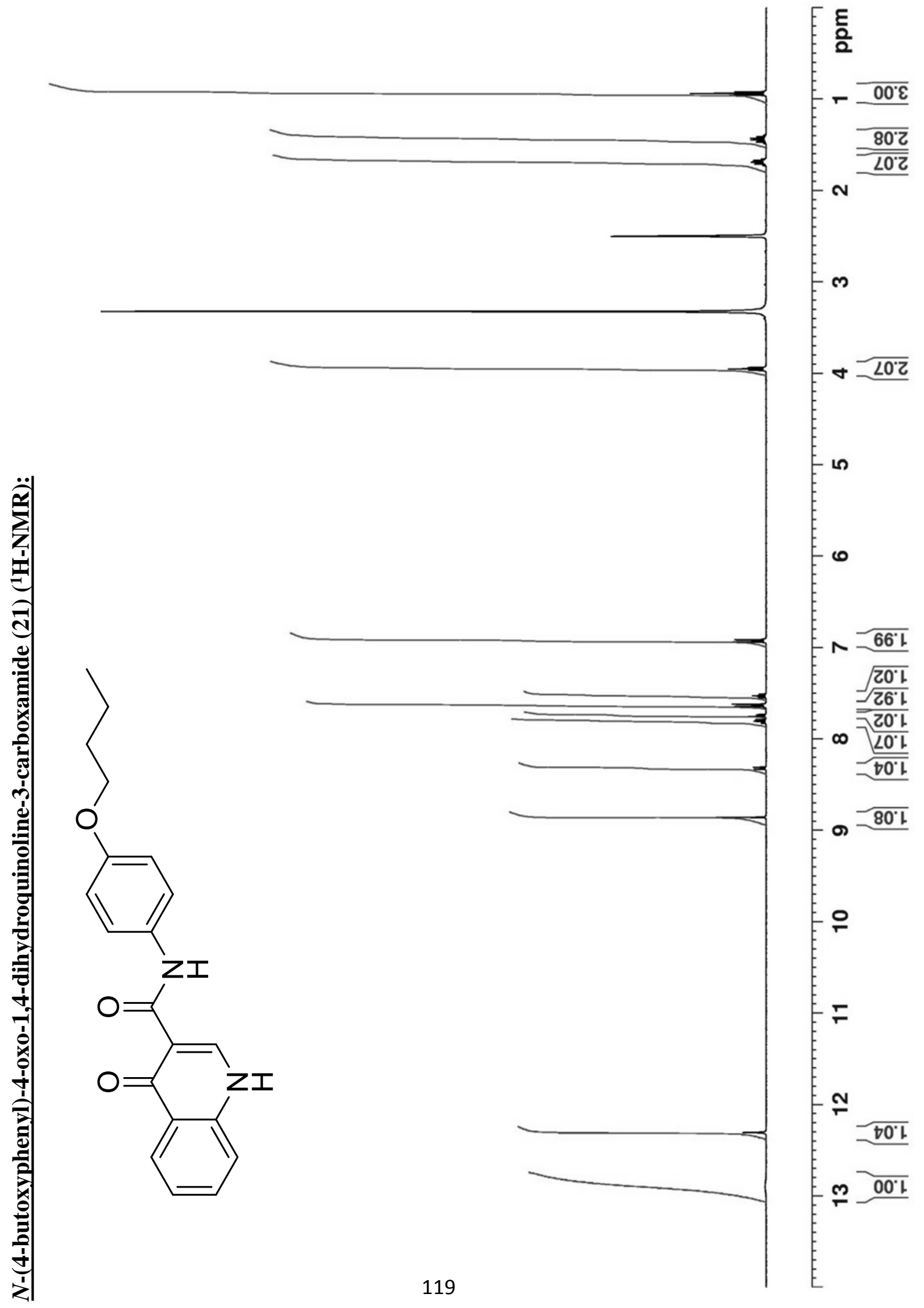




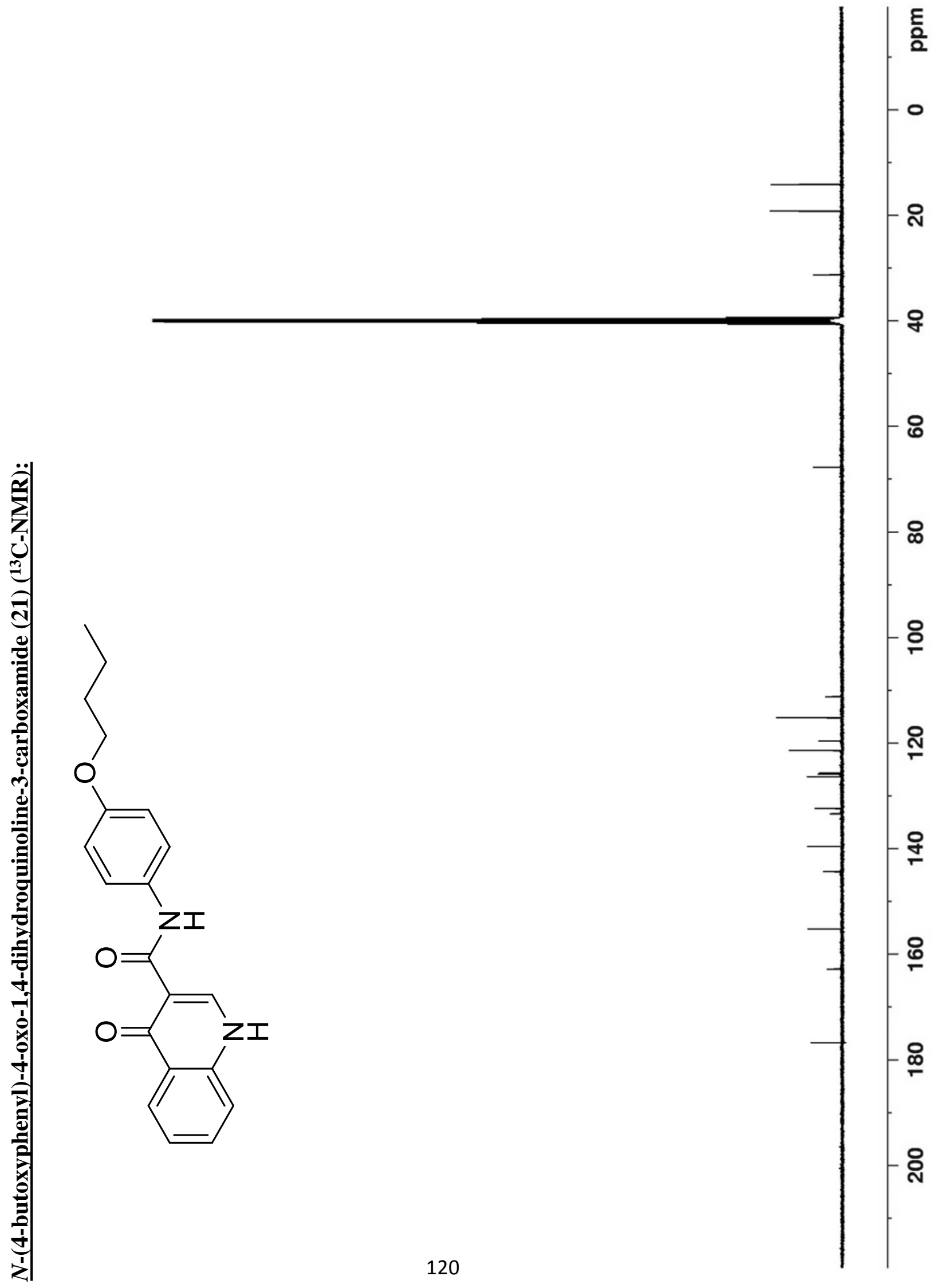




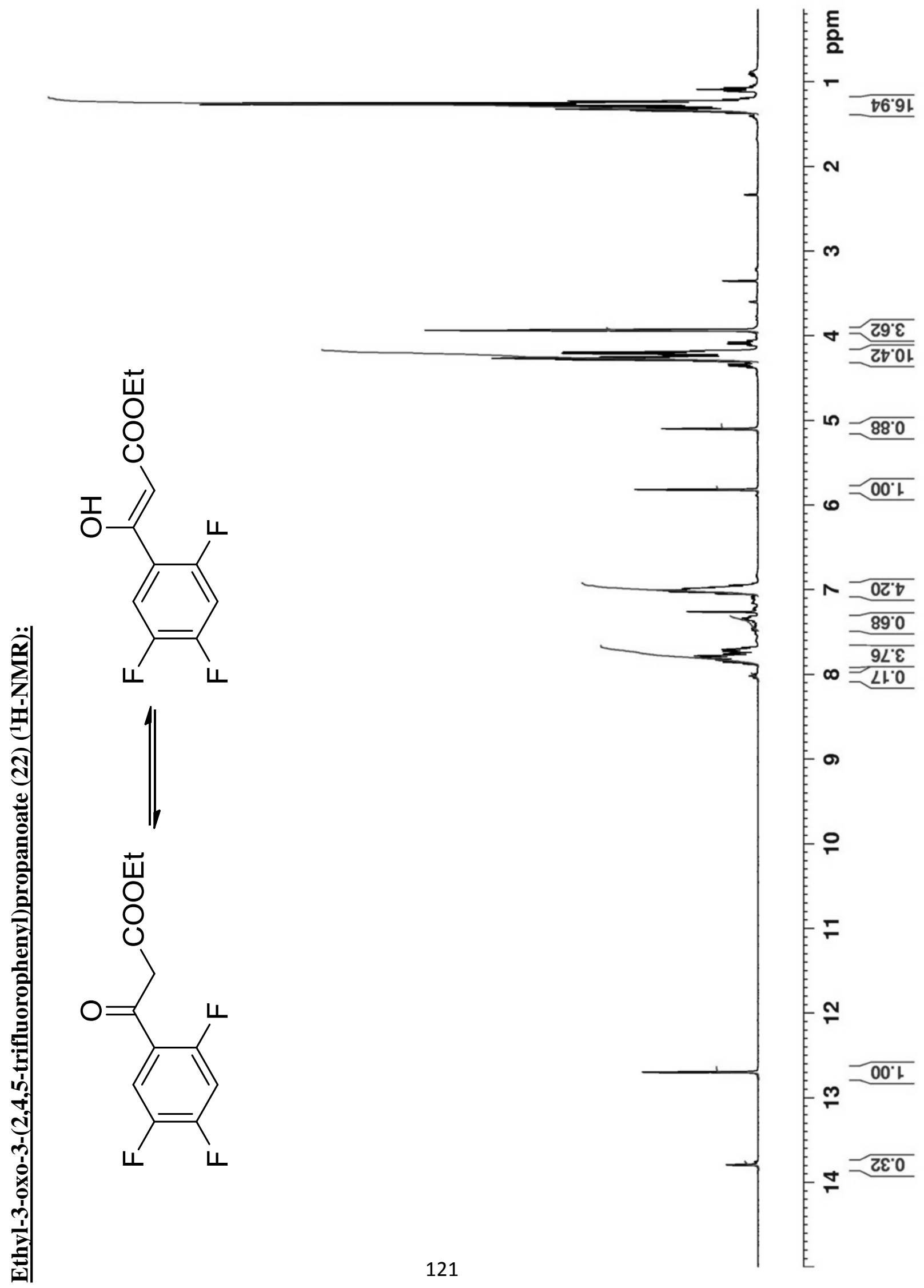




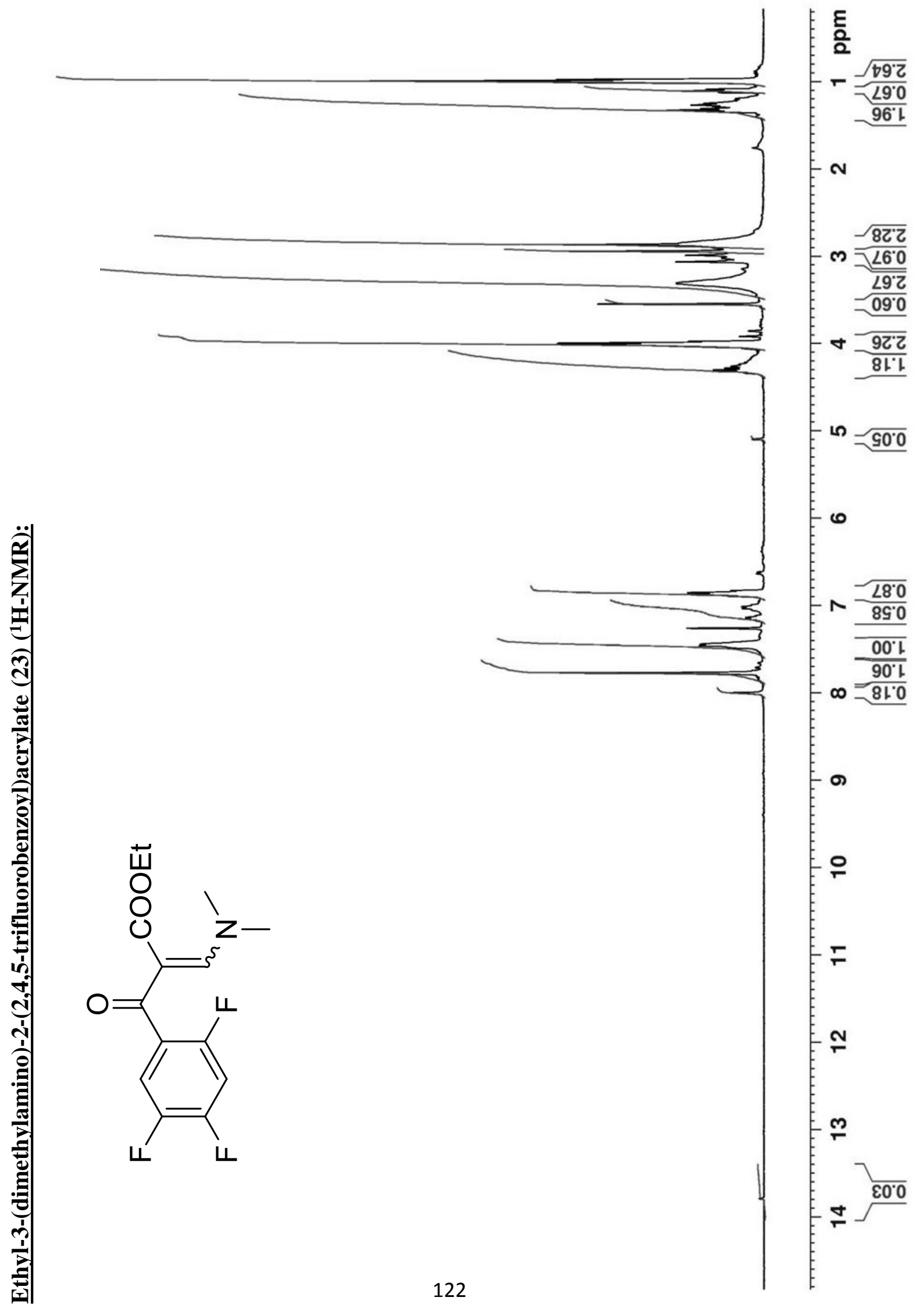




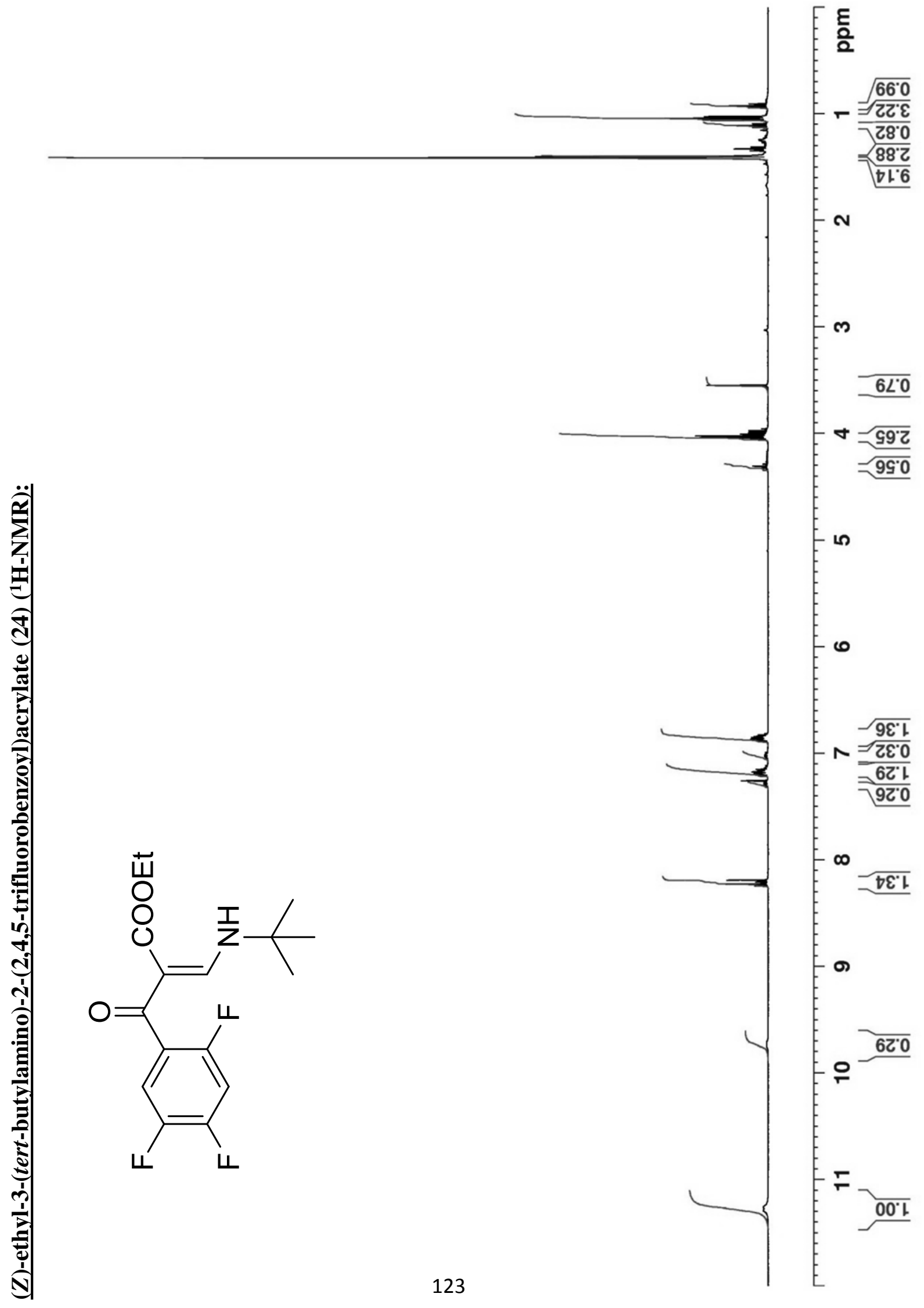




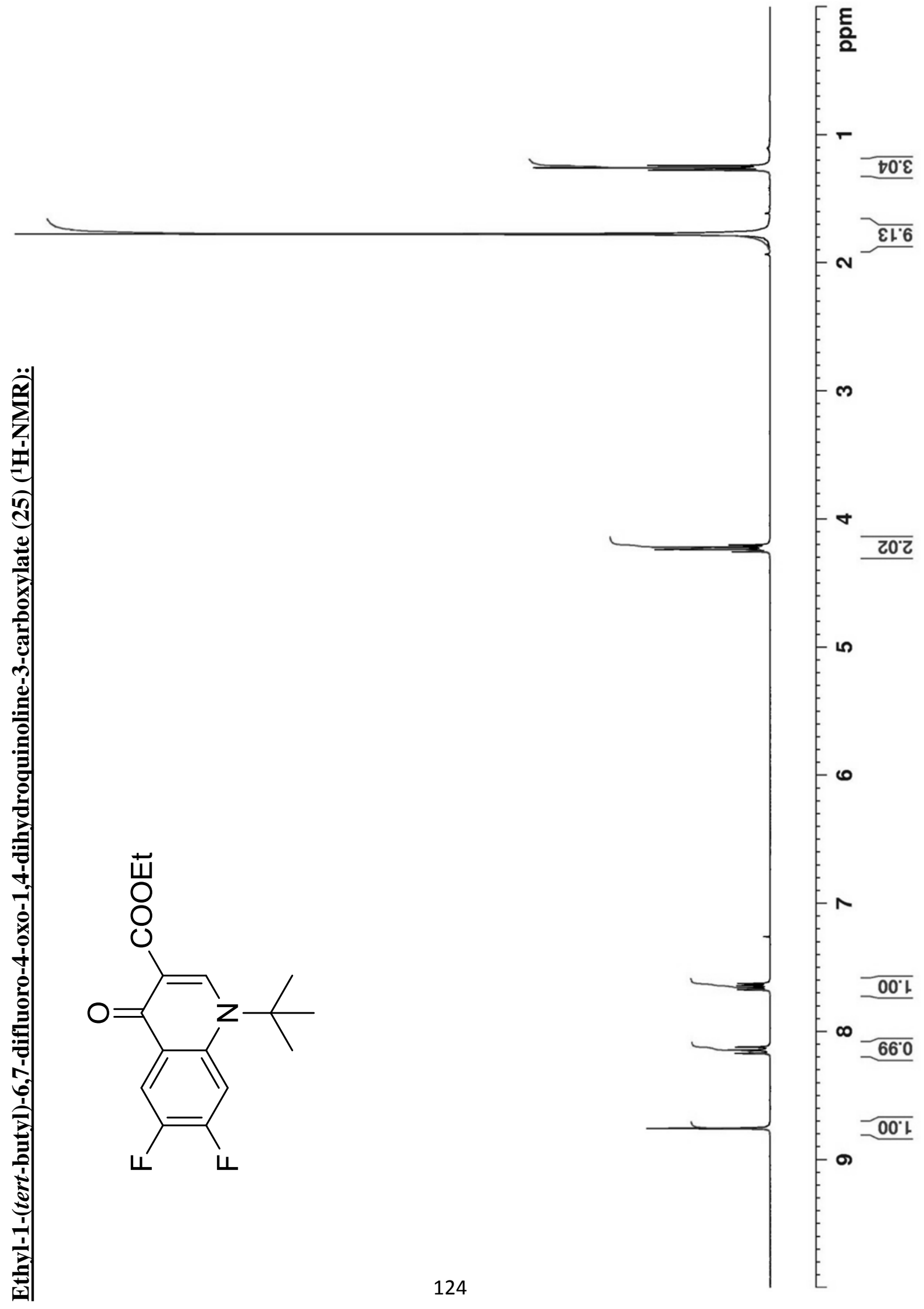




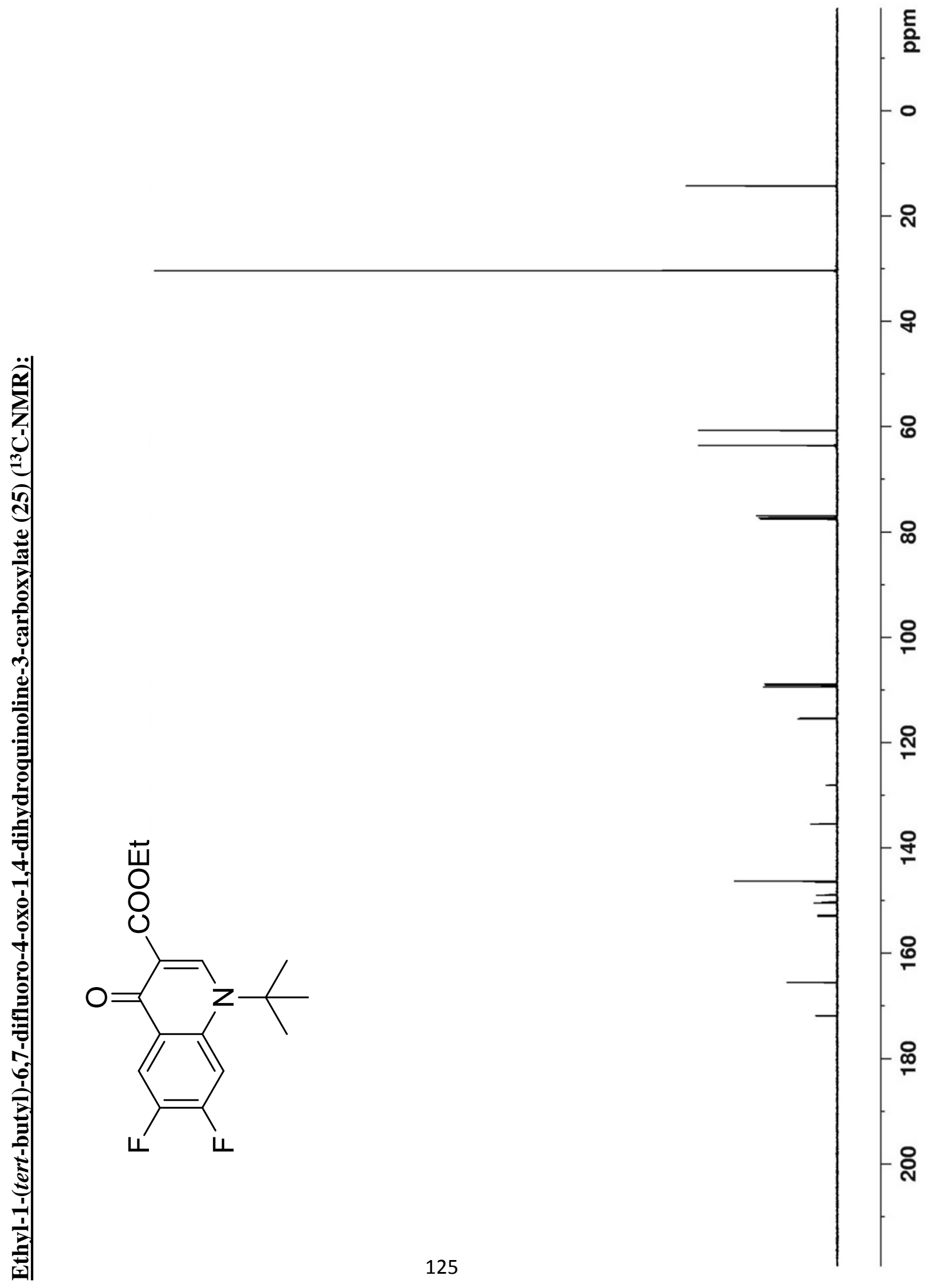



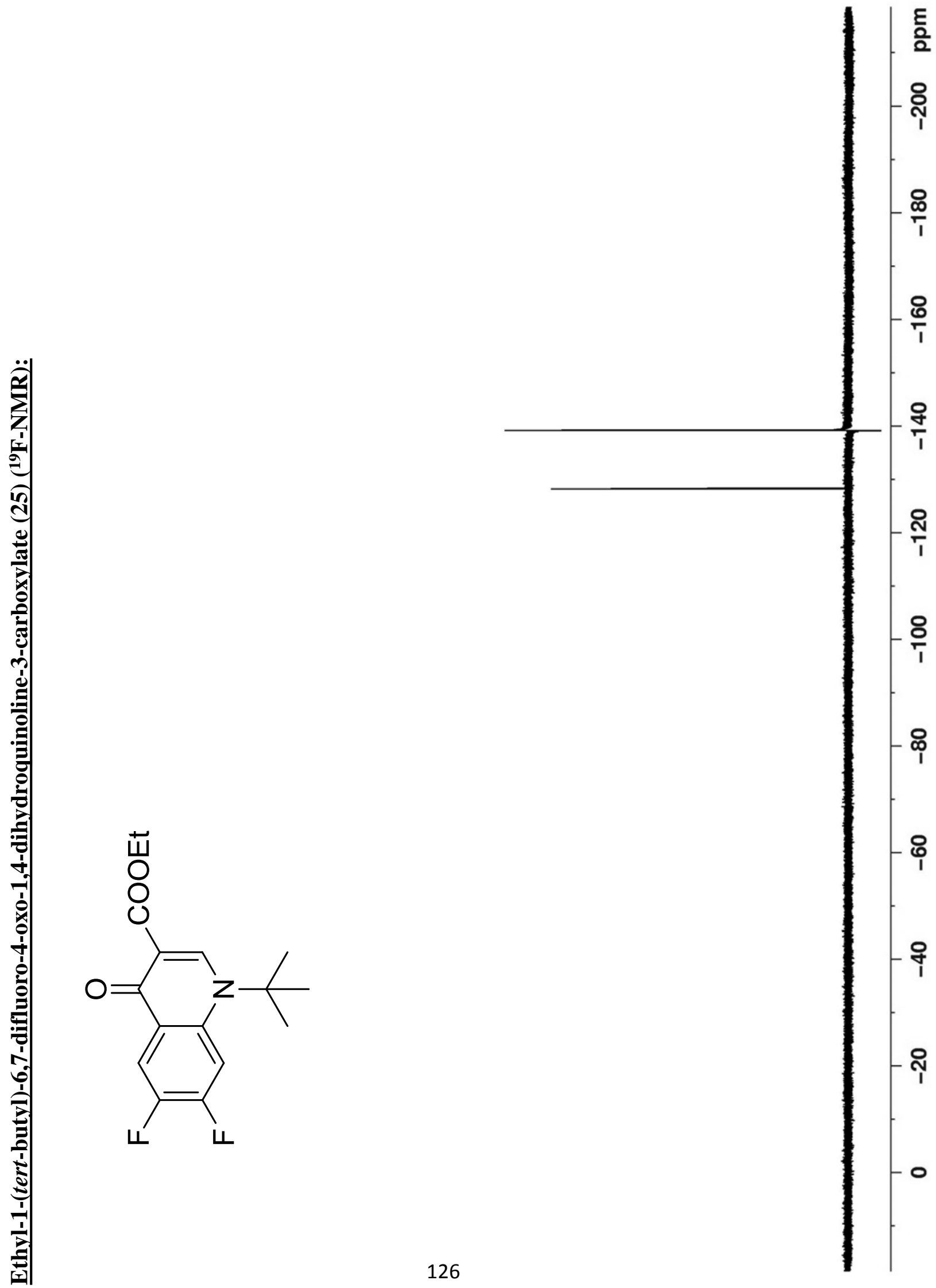


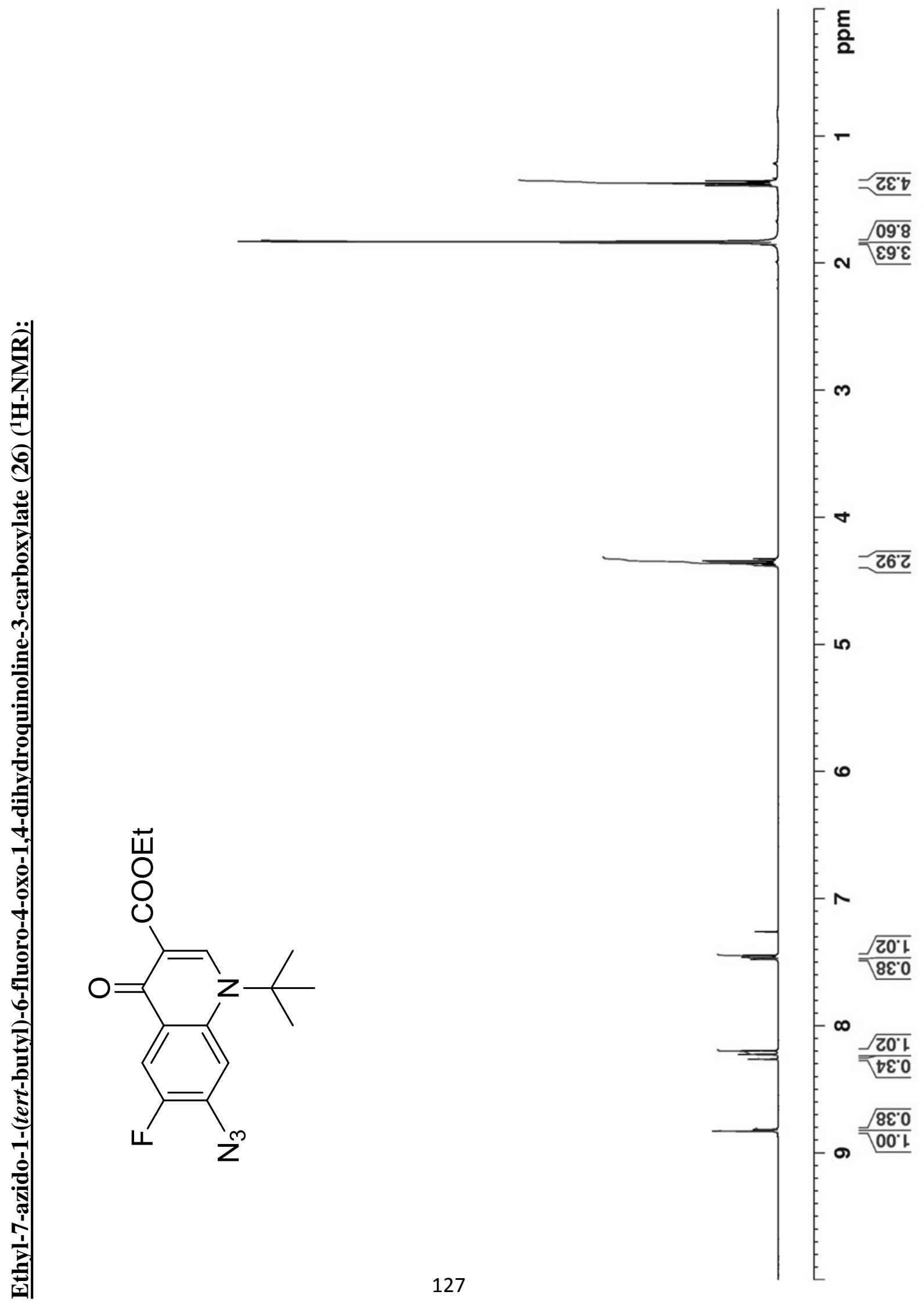




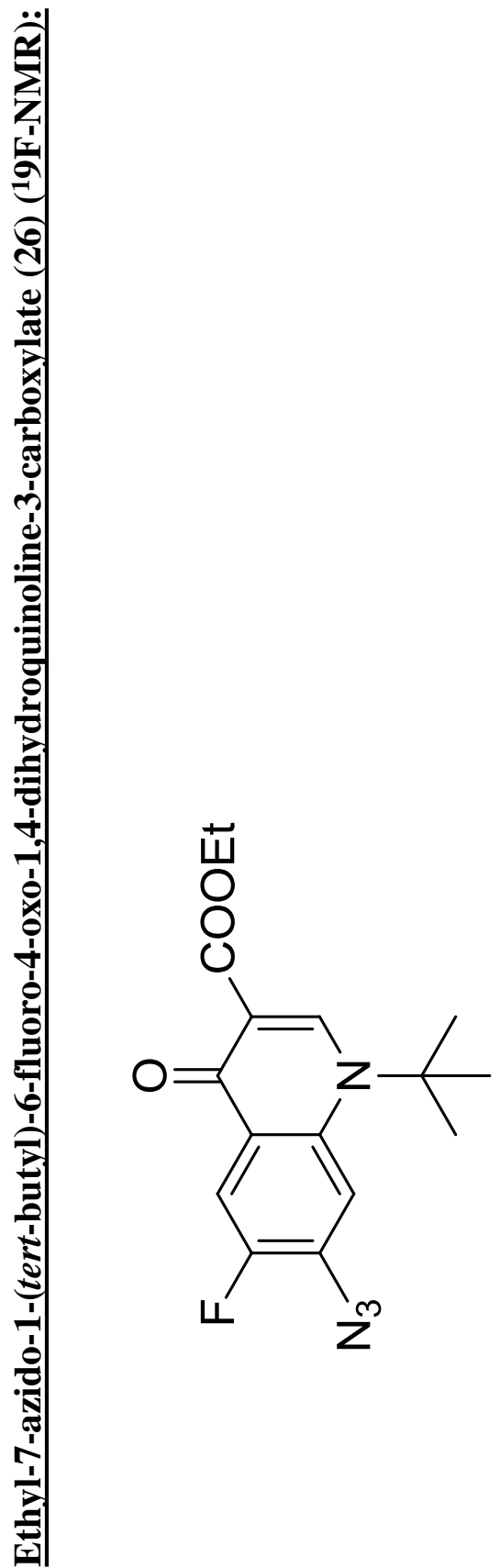




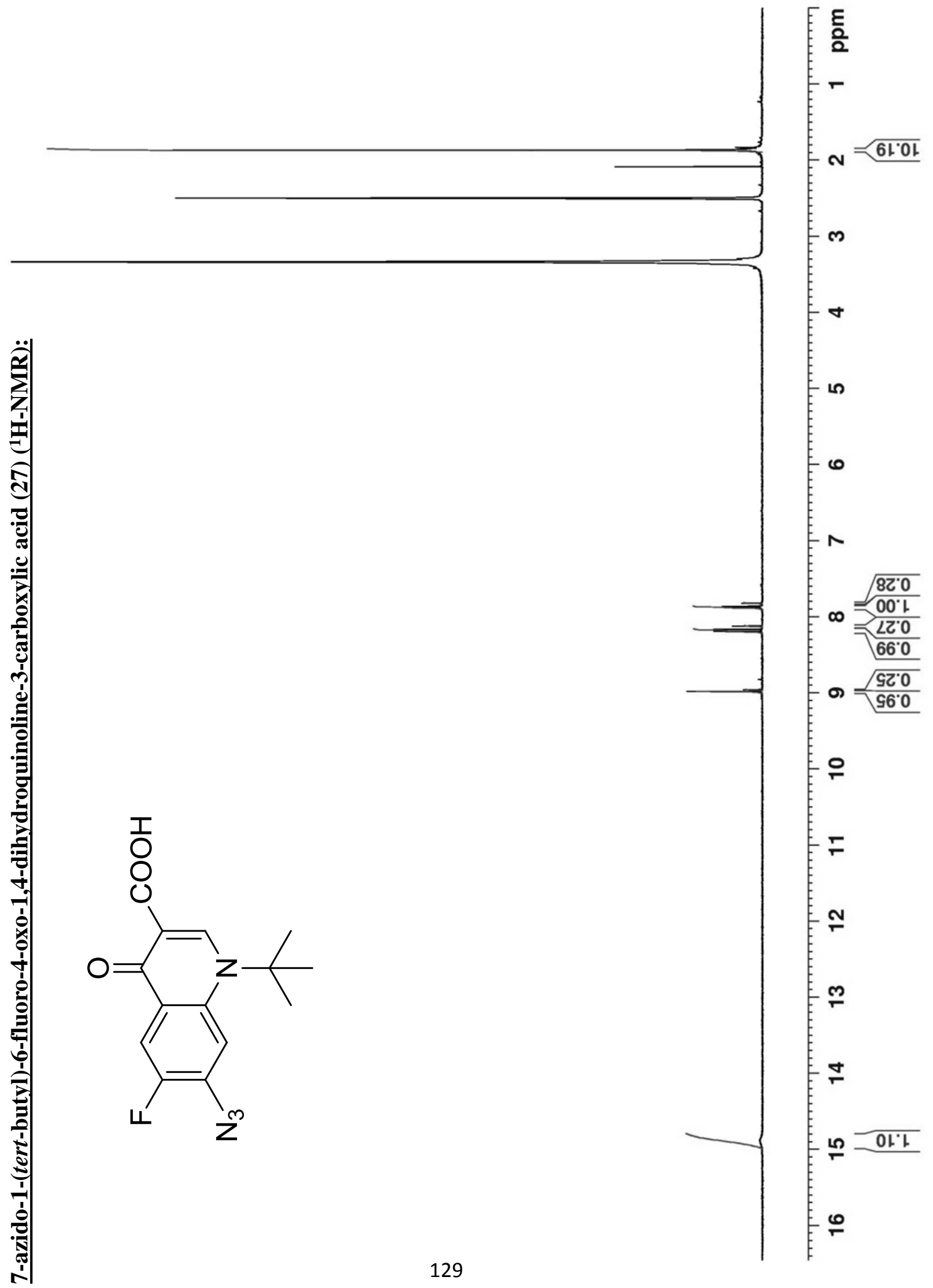



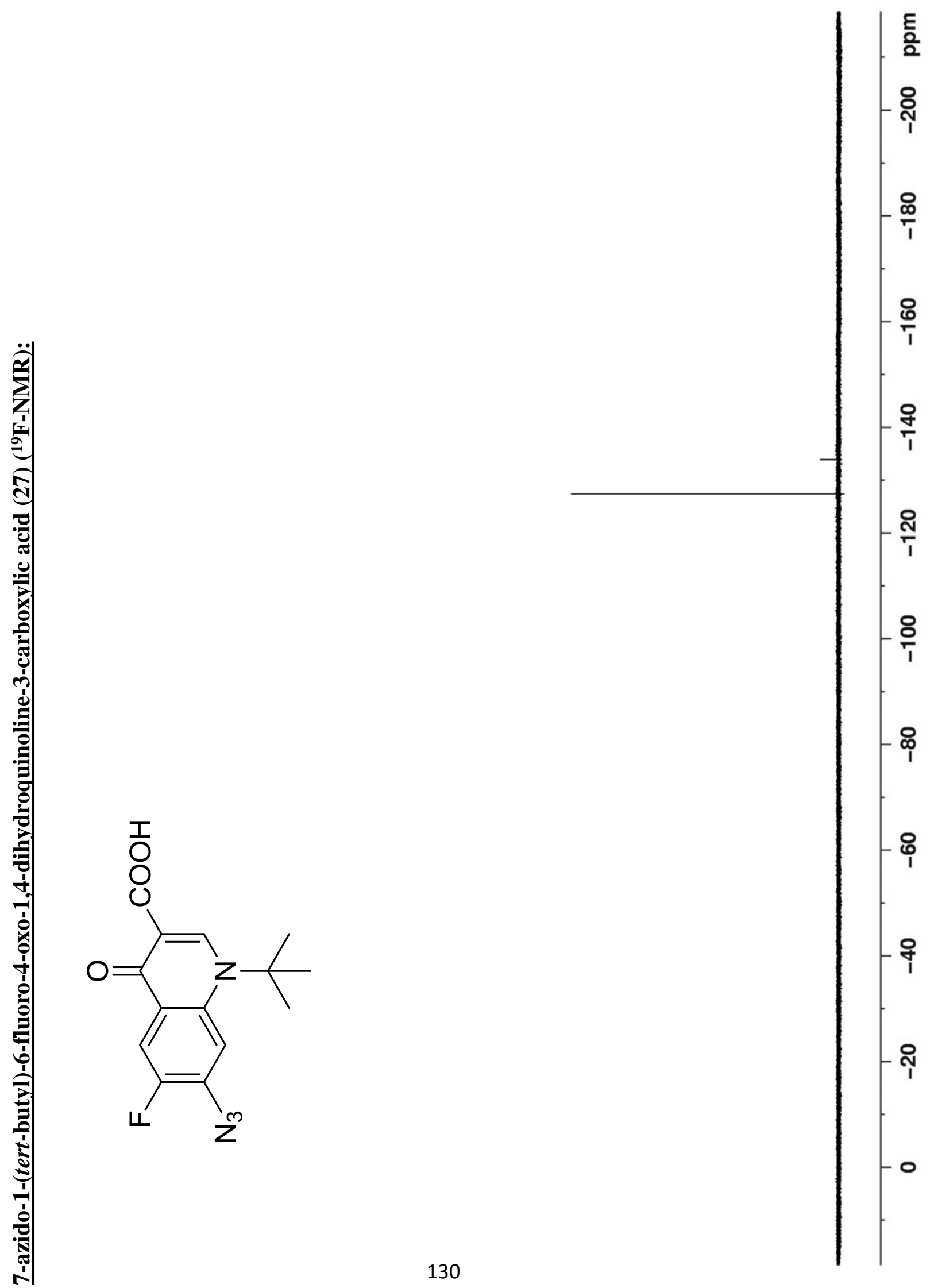


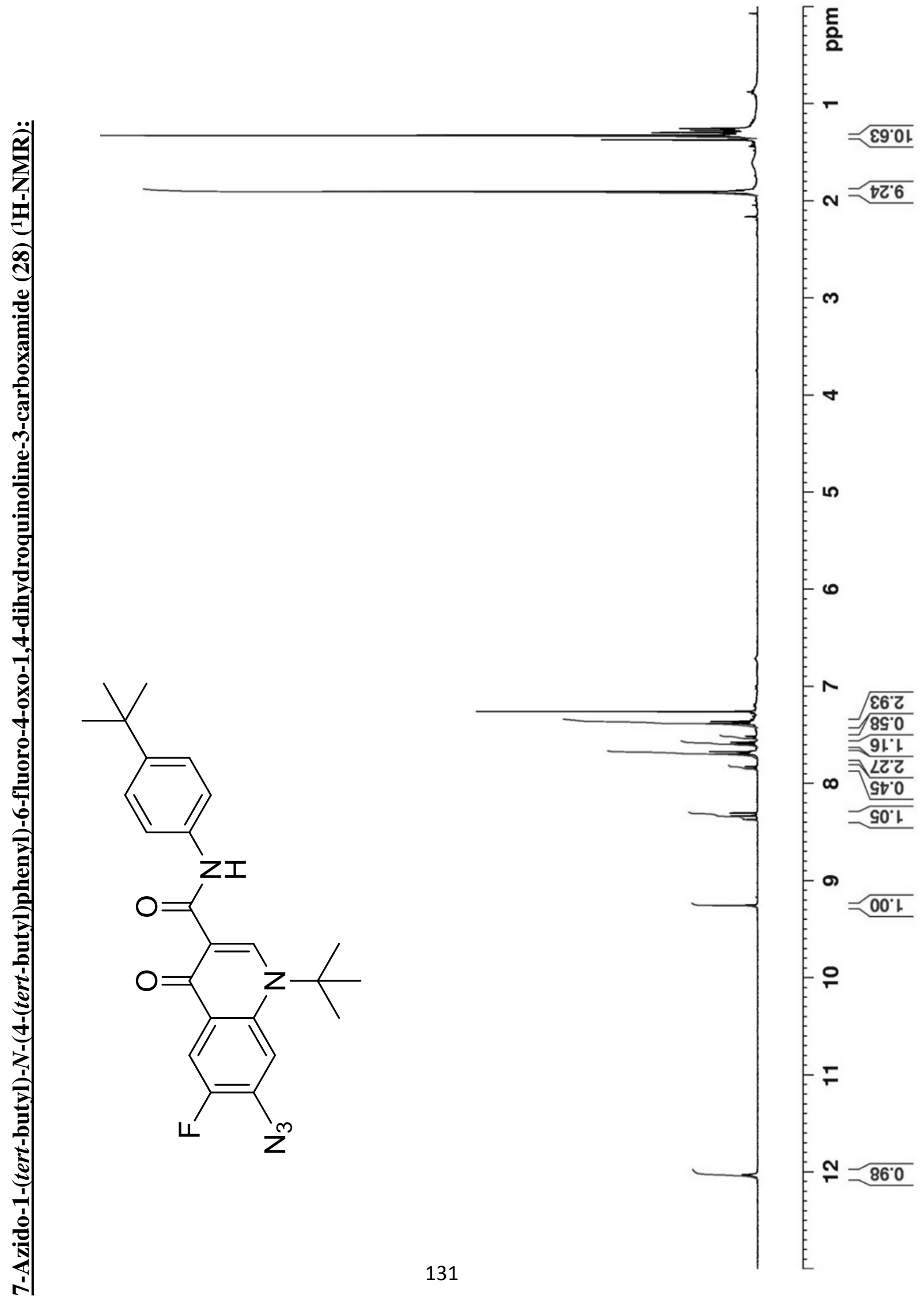




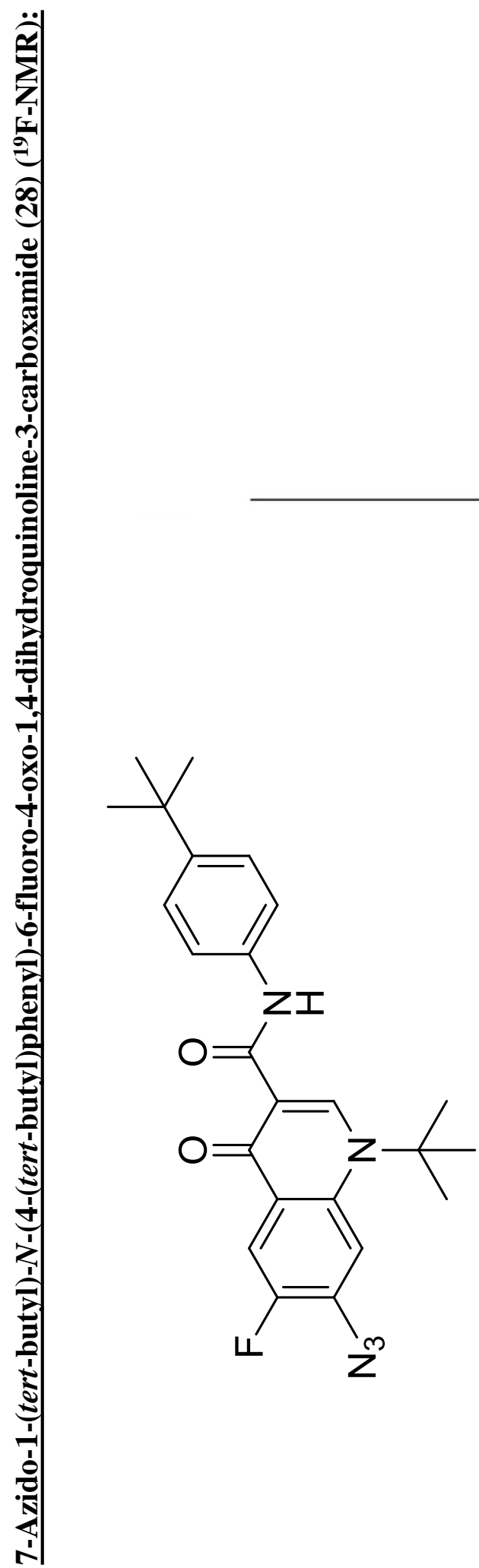




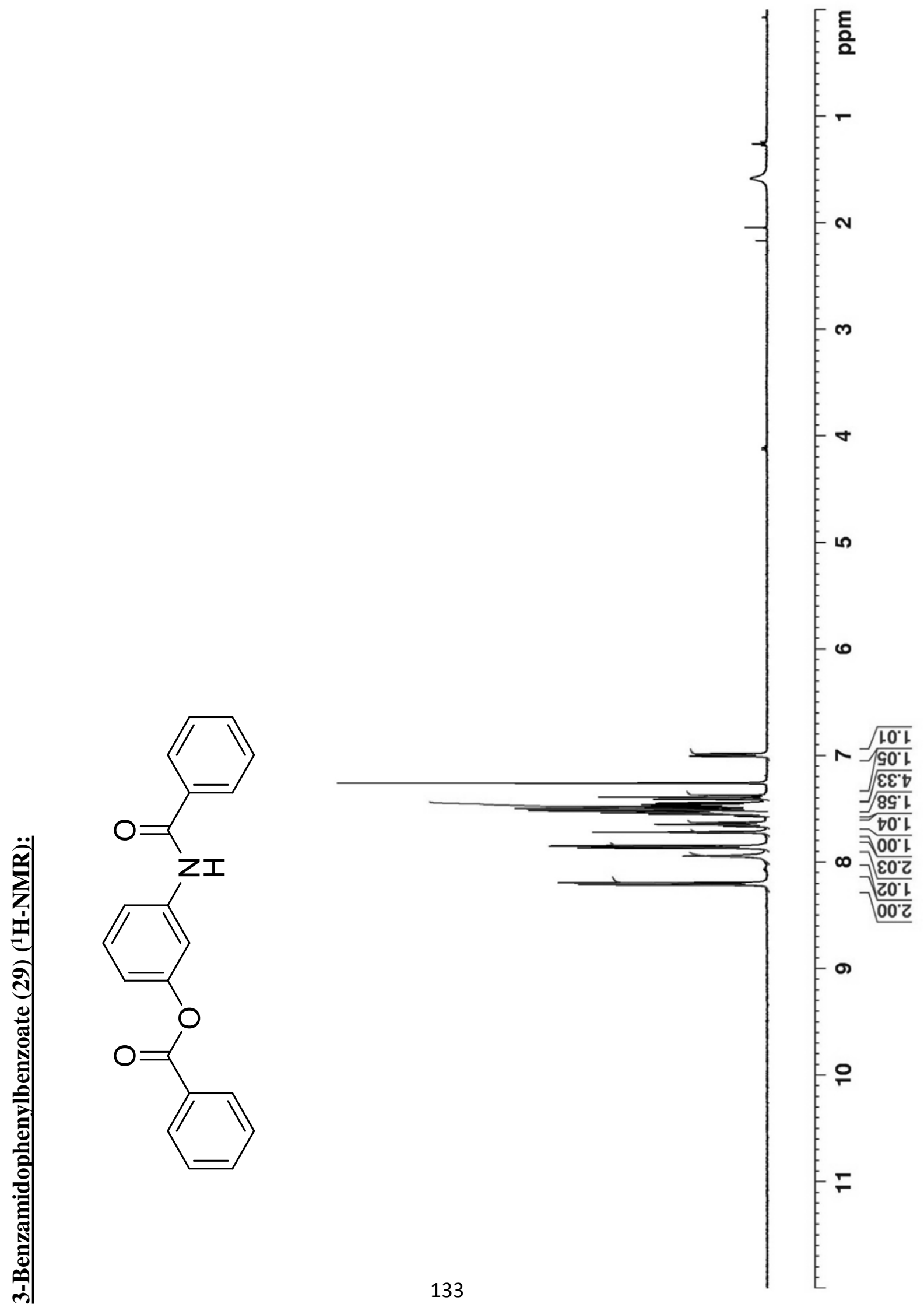




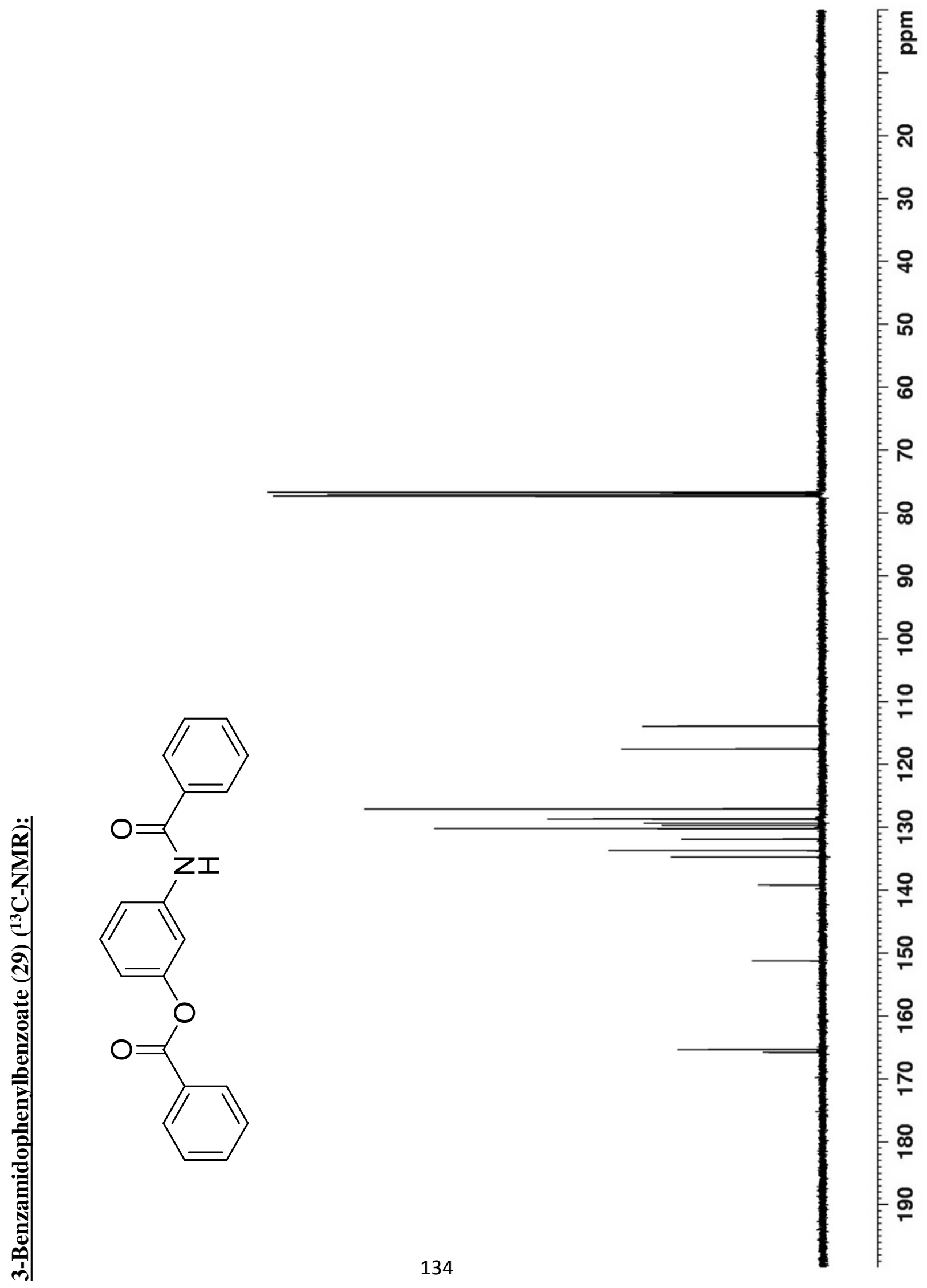




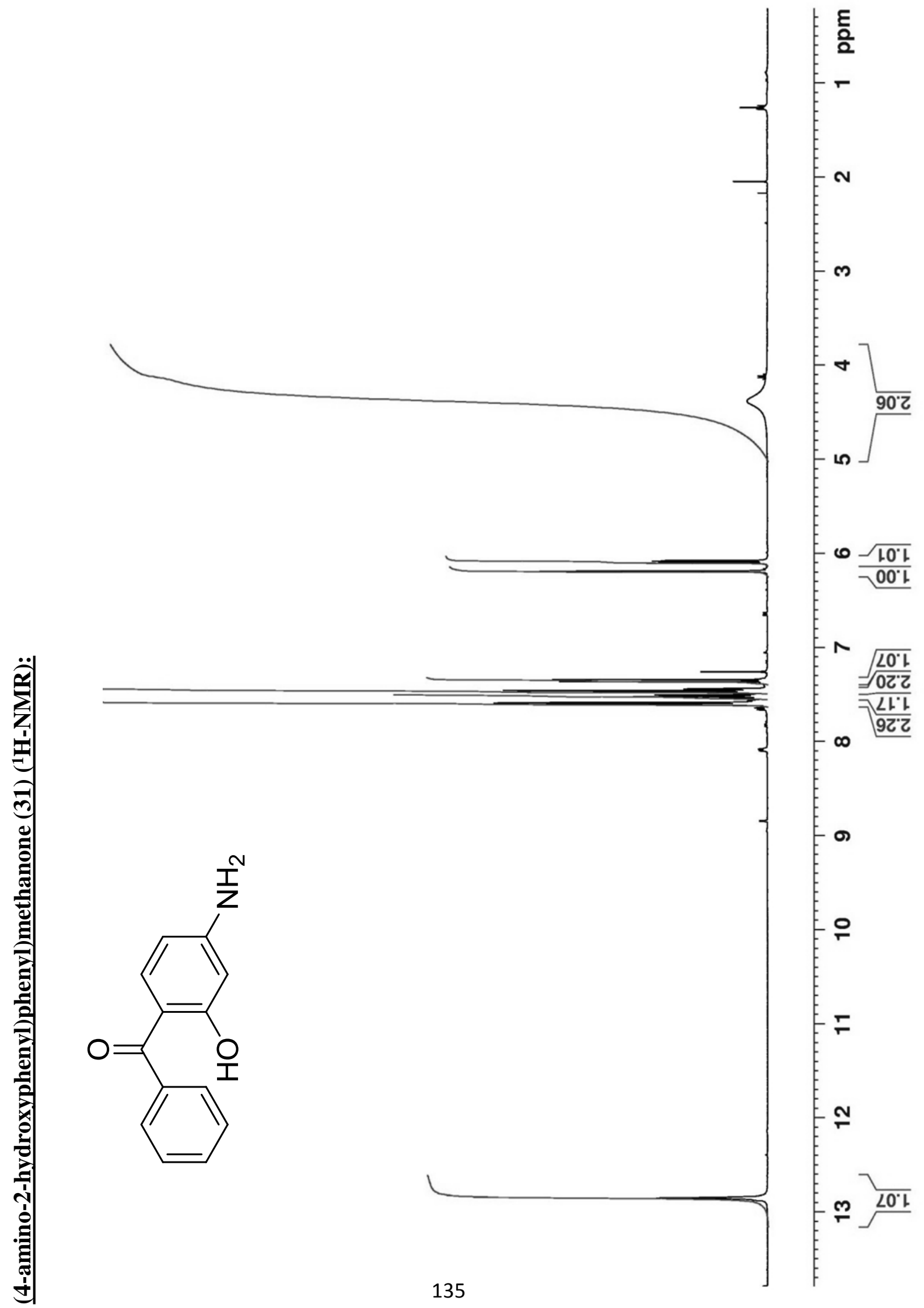




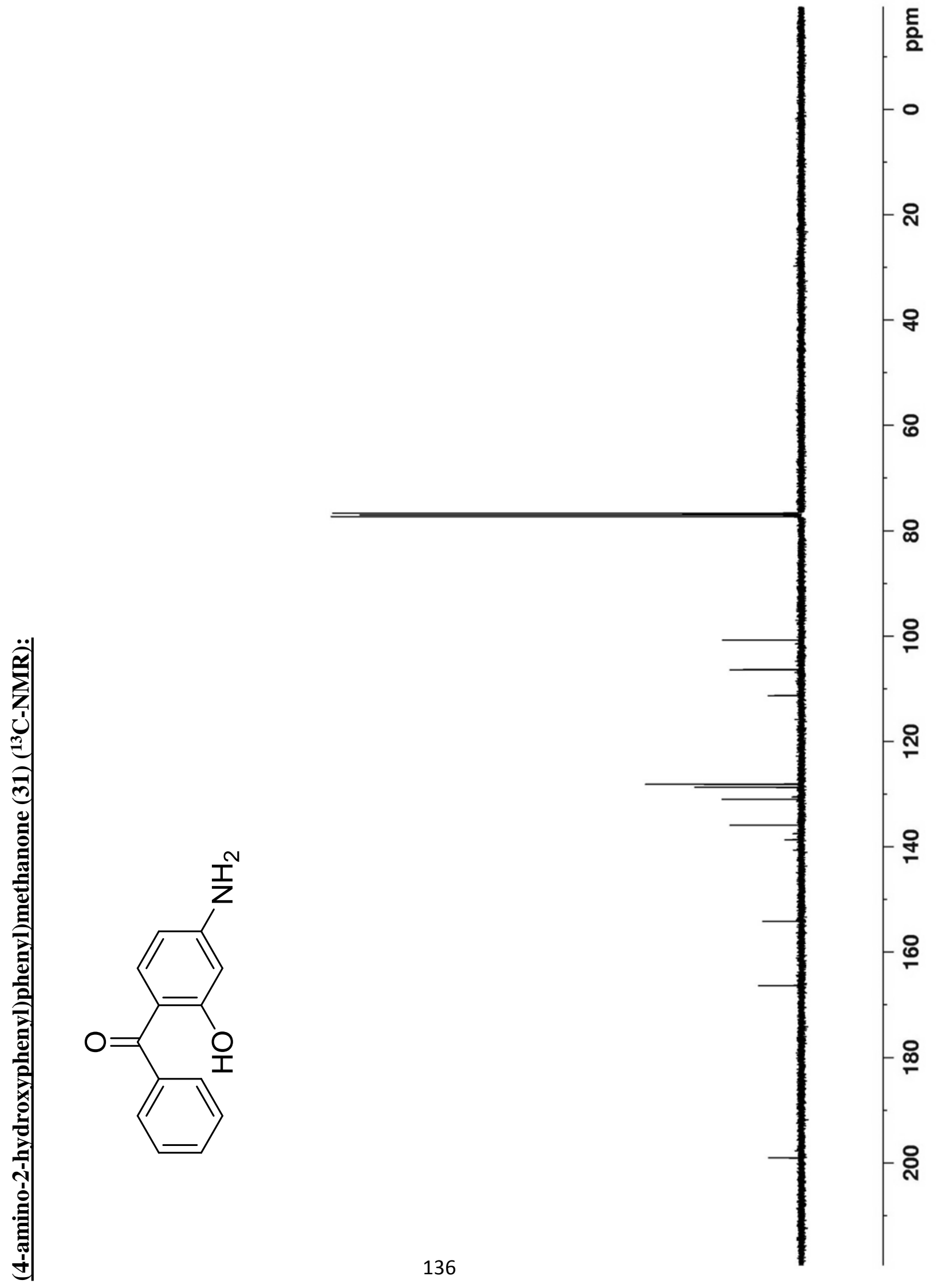



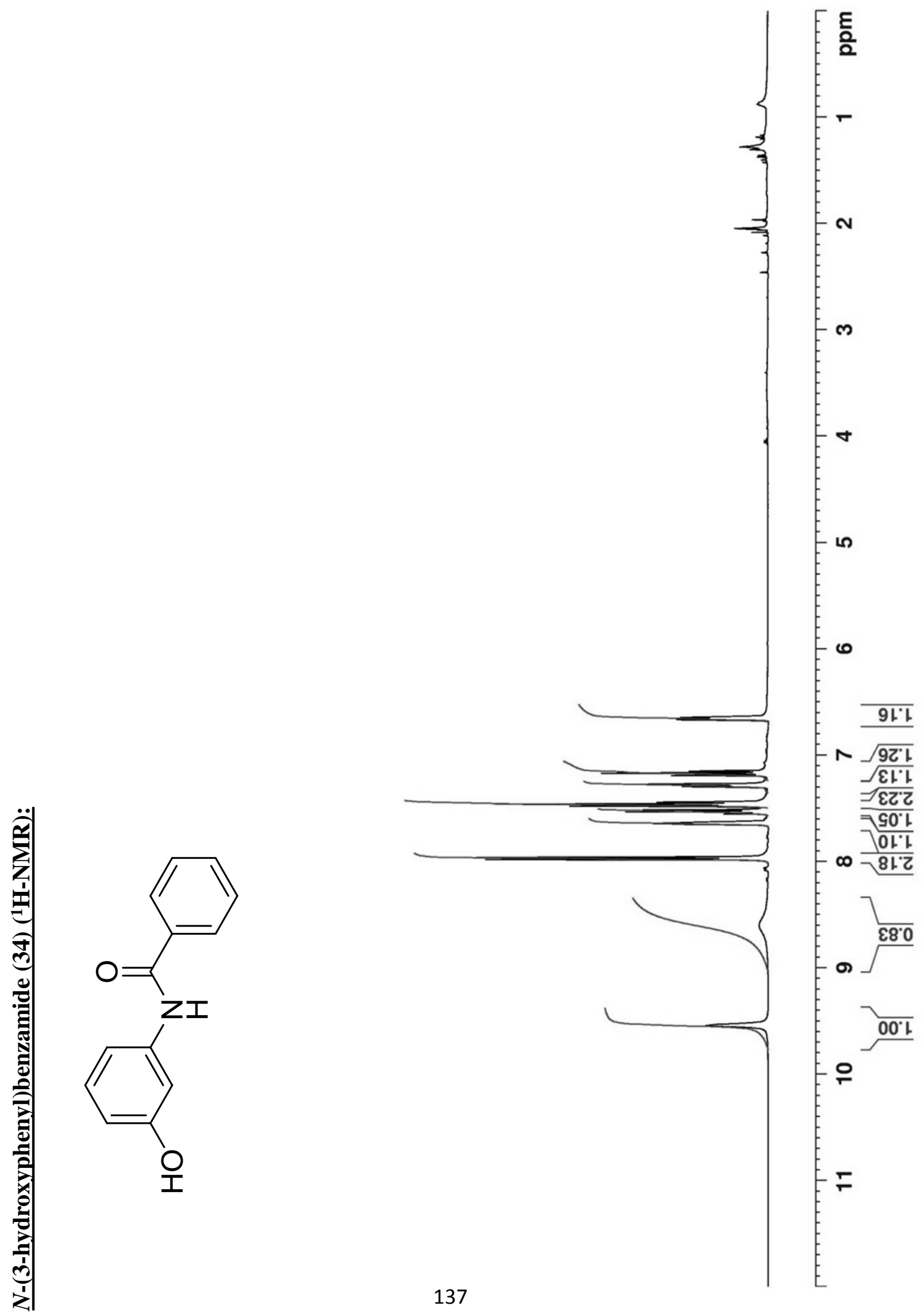


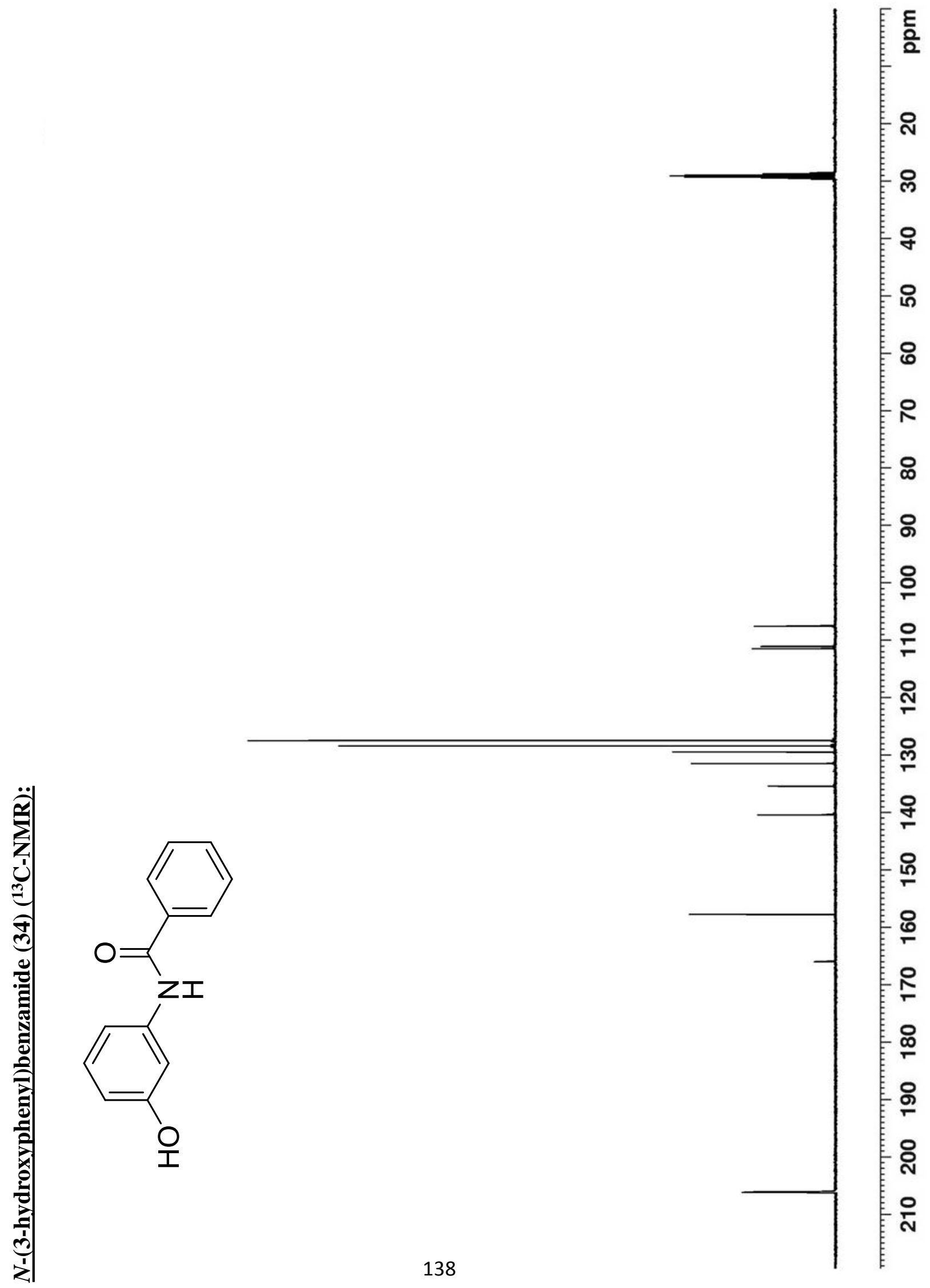




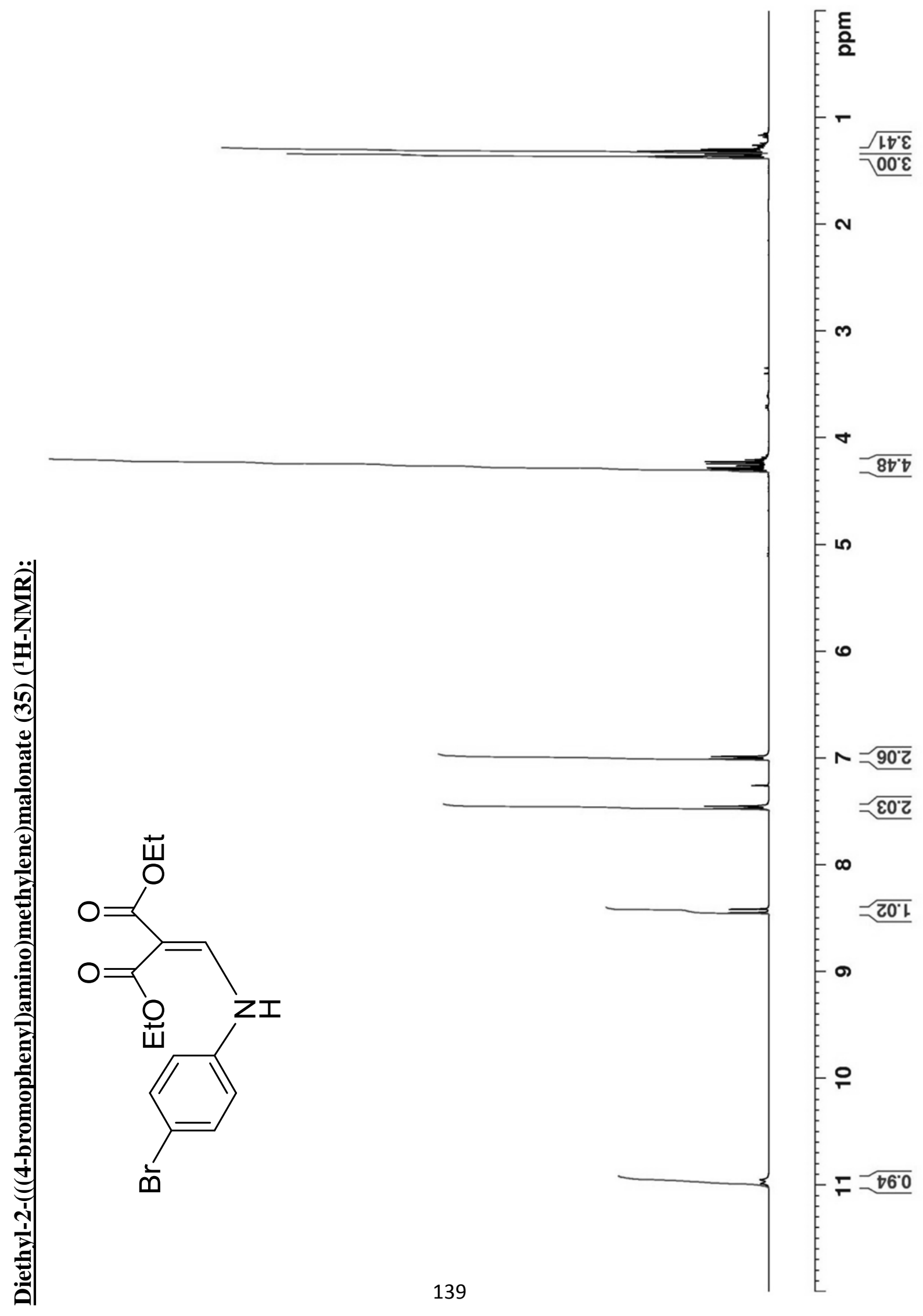



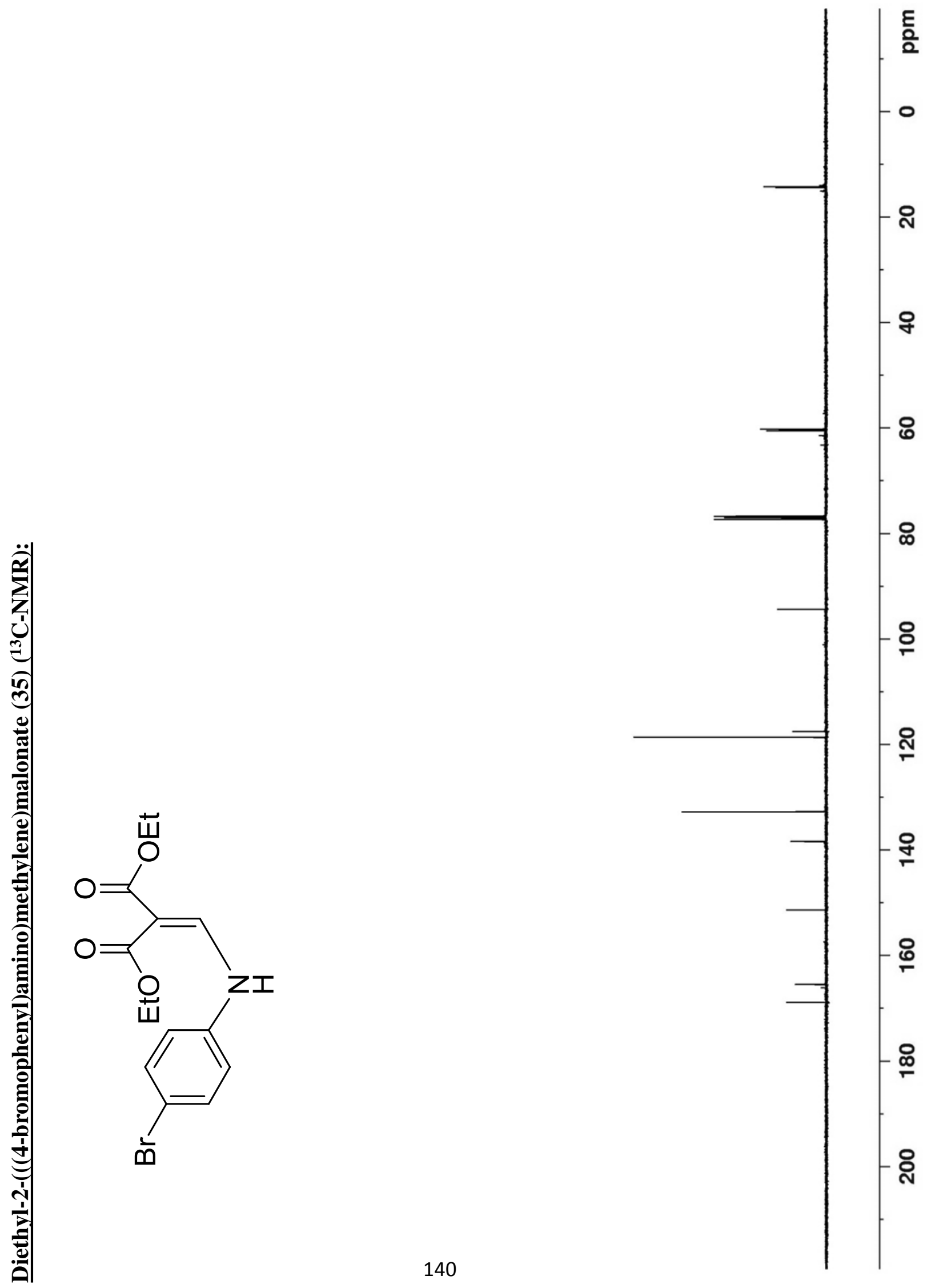

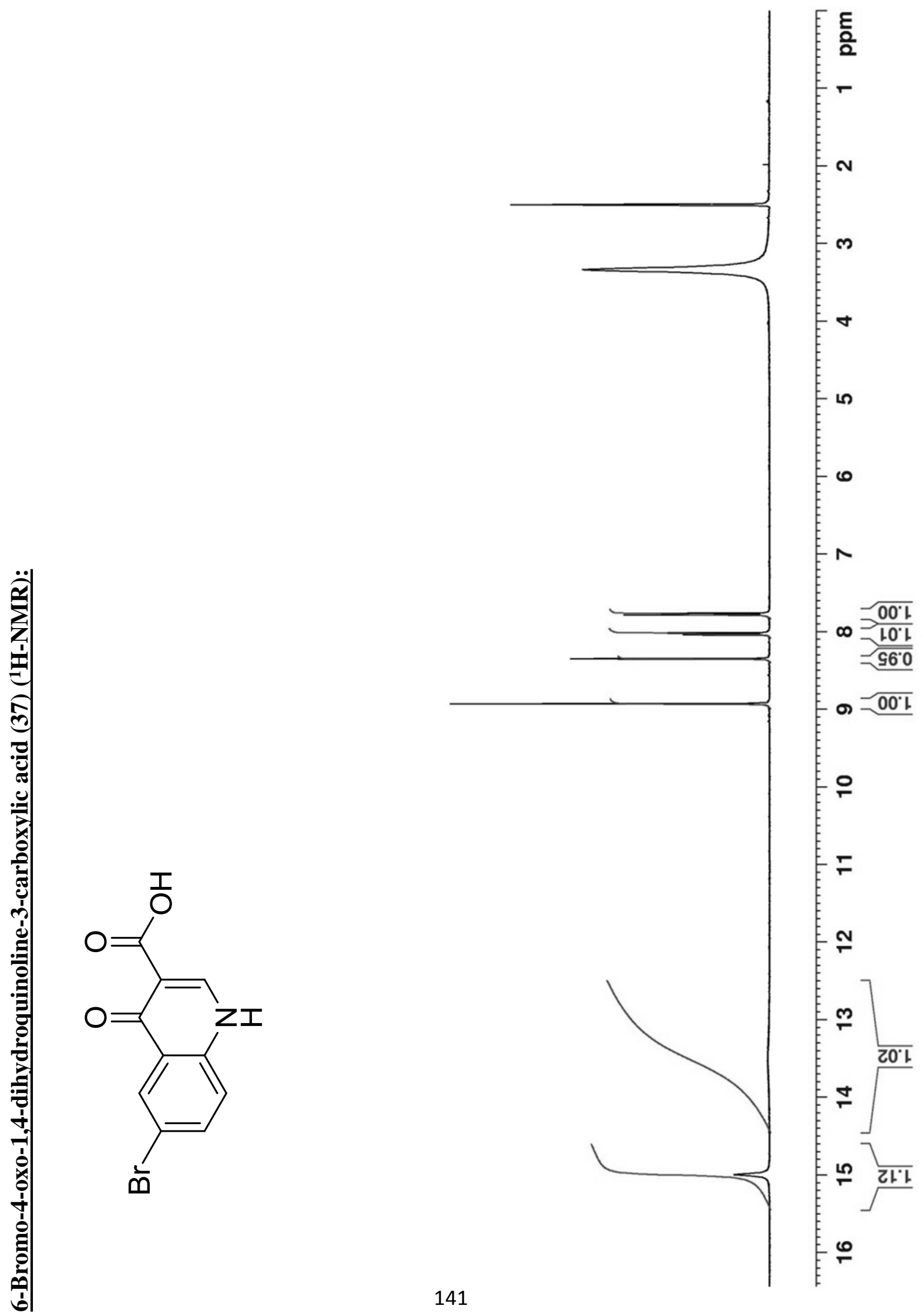


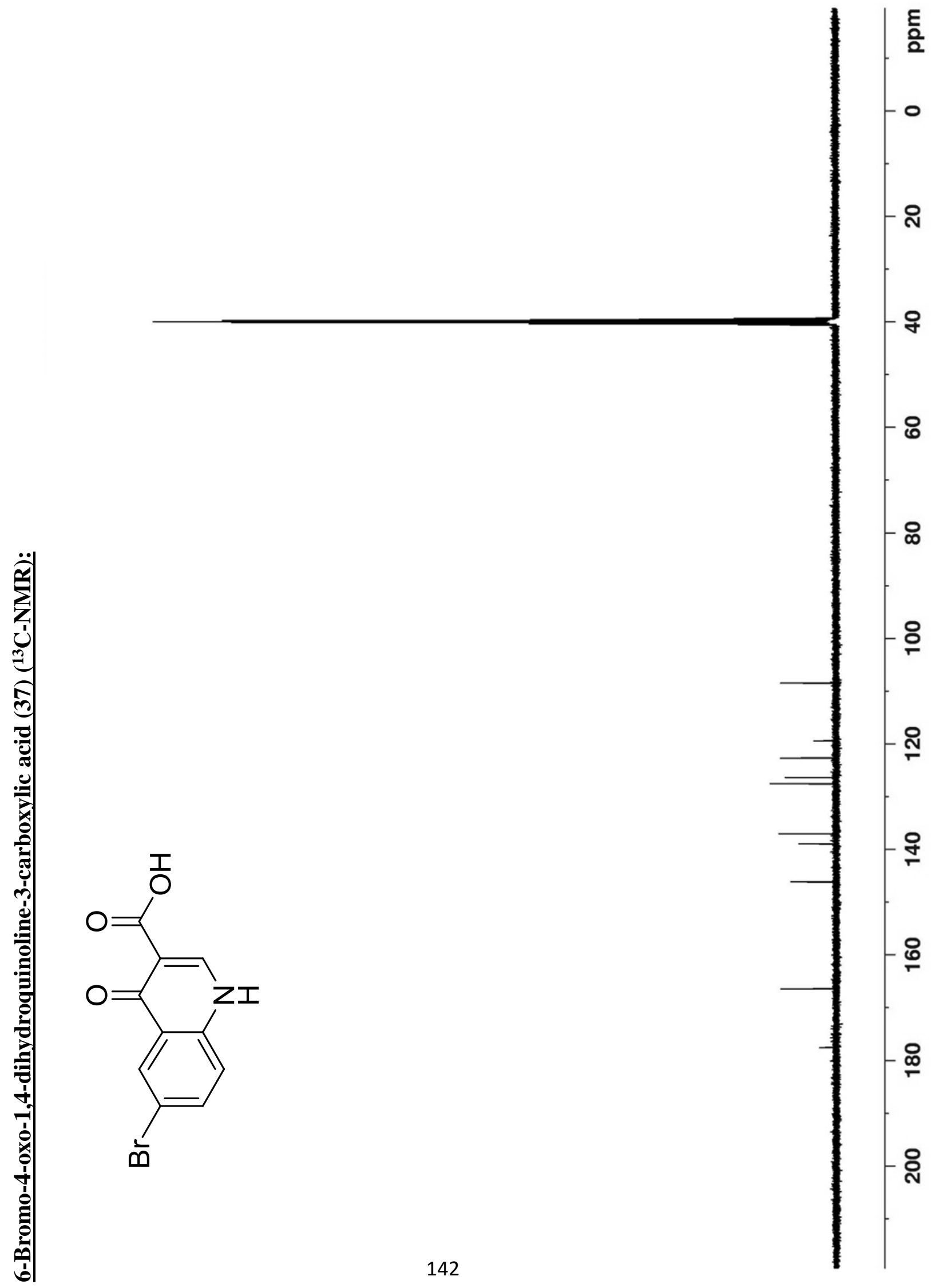




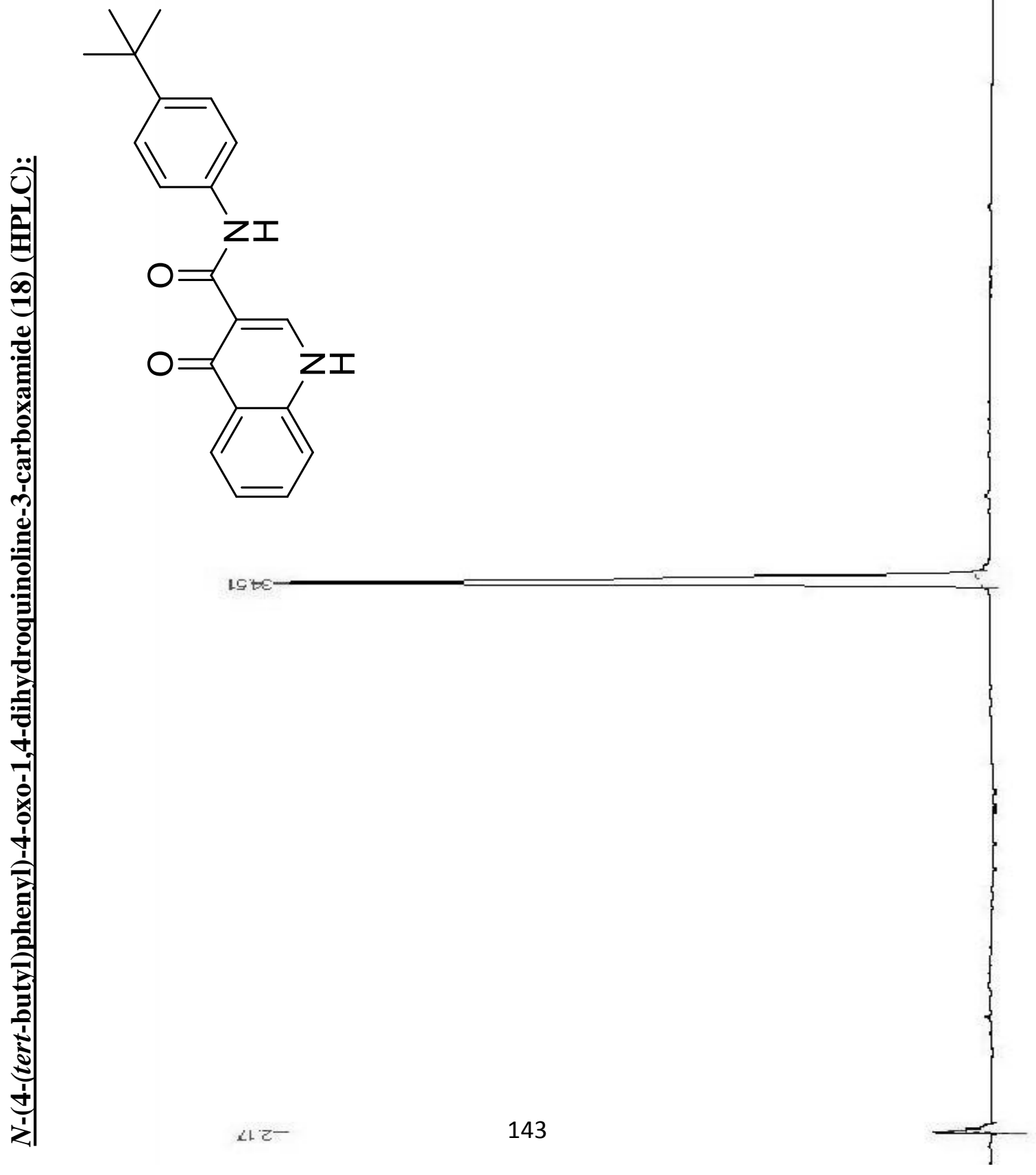


Software Version $\quad:$ 6.3.2.0646

Operator : balkhour

Sample Number : : 001

AutoSampler : SER200

Instrument Name : HPLC

Instrument Serial \# : None

Delay Time

Sampling Rate

Sample Volume

Sample Amount

Data Acquisition Time
: $0.00 \mathrm{~min}$

: $2.5000 \mathrm{pts} / \mathrm{s}$

: $1.000000 \mathrm{ul}$

: 1.0000

: 3/21/2012 8:26:09 PM
Date $\quad: 8 / 21 / 2012$ 2:36:12 PM

Sample Name : 4-t-Bu aniline (5)

Study

Rack/Vial $\quad: 1 / 1$

Channel : B

A/D mV Range : 1000

End Time : $94.99 \mathrm{~min}$

Area Reject $\quad: 0.000000$

Dilution Factor : 1.00

Cycle $: 1$

Raw Data File : C:IHPLC Dataldatb001-20120321-202617.raw

Inst Method : C:IHPLC DatalSalmal4-t-Bu aniline (5) from C:IHPLC Dataldatb001-20120321-202617.raw

Proc Method : C:IHPLC DatalSalmal4-t-Bu aniline (5).mth from

Calib Method : C:IHPLC DatalSalmal4-t-Bu aniline (5).mth from

Report Format File: C:IHPLC DatalSalmal4-t-Bu aniline (5).rpt

Sequence File : C:IHPLC DatalSalmal4-t-Bu aniline (5).seq

\section{DEFAULT REPORT}

\begin{tabular}{|c|c|c|c|c|c|c|c|}
\hline $\begin{array}{c}\text { Peak } \\
\#\end{array}$ & $\begin{array}{l}\text { Time } \\
\text { [min] }\end{array}$ & $\begin{array}{c}\text { Area } \\
{[\mu \mathrm{V} \cdot \mathrm{s}]}\end{array}$ & $\begin{array}{c}\text { Height } \\
{[\mu \mathrm{V}]}\end{array}$ & $\begin{array}{c}\text { Area } \\
{[\%]}\end{array}$ & $\begin{array}{c}\text { Norm. Area } \\
{[\%]}\end{array}$ & $\mathrm{BL}$ & $\begin{array}{c}\text { Area/Height } \\
{[\mathrm{s}]}\end{array}$ \\
\hline - & 0.001 & 0.00 & 0.00 & 0.00 & 0.00 & & \\
\hline 1 & 2.165 & 63364.80 & 12871.34 & 1.43 & 1.43 & BB & 4.9229 \\
\hline 2 & 34.508 & 4271514.80 & 178832.39 & 96.45 & 96.45 & BB & 23.8856 \\
\hline 3 & 83.657 & 93687.80 & 13338.53 & 2.12 & 2.12 & BB & 7.0238 \\
\hline
\end{tabular}

$\begin{array}{llll}4428567.40 & 205042.27 \quad 100.00 \quad 100.00\end{array}$

Missing Component Report

Component Expected Retention (Calibration File)

4-t-Bu aniline (5)

0.001 


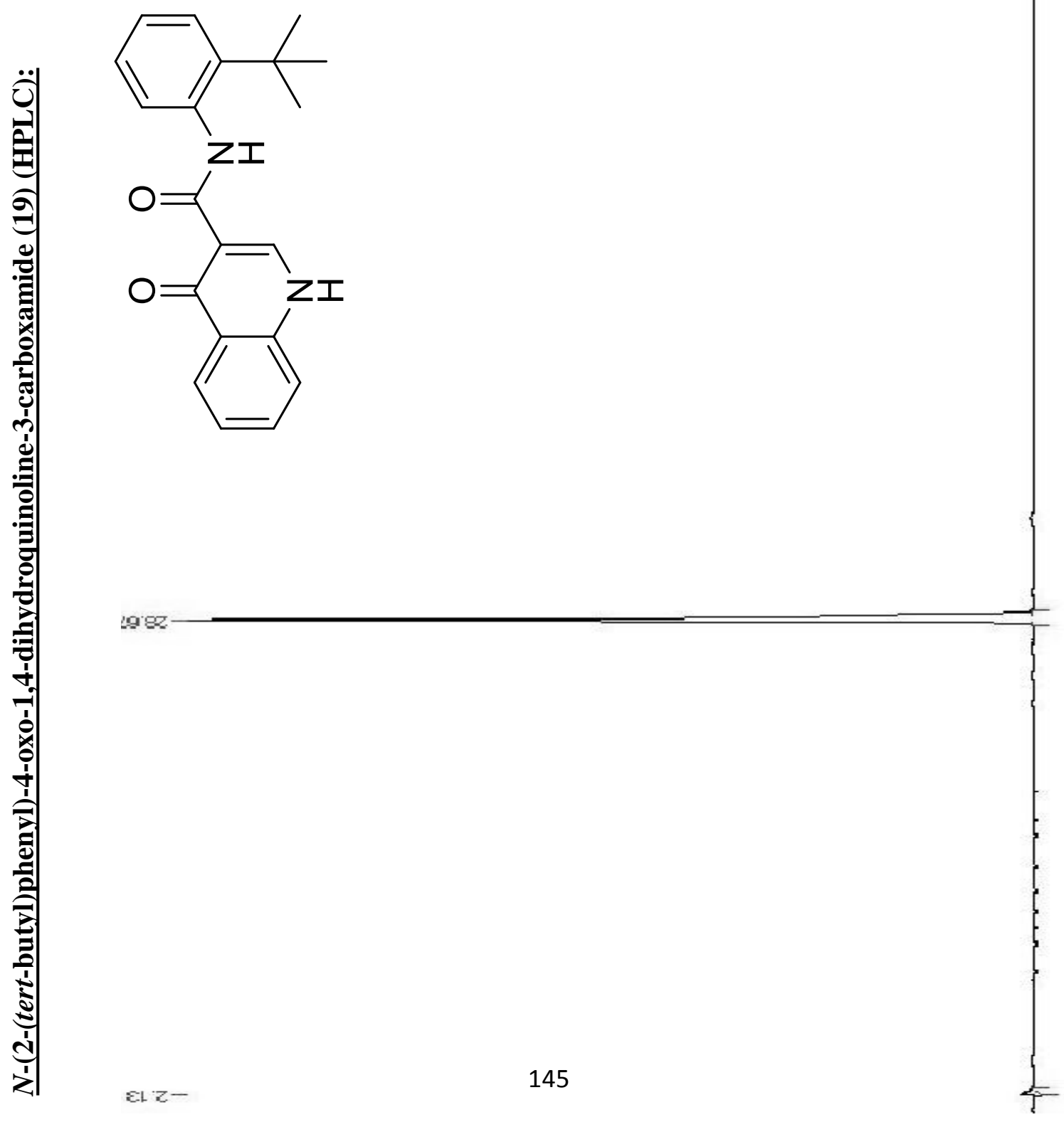




$\begin{array}{llll}\text { Software Version } & : \text { 6.3.2.0646 } & \text { Date } & : \text { 8/21/2012 2:31:38 PM } \\ \text { Operator } & : \text { balkhour } & \text { Sample Name } & : \text { 2-t-Buaniline (3) } \\ \text { Sample Number } & : 001 & \text { Study } & \vdots \\ \text { AutoSampler } & : \text { SER200 } & \text { Rack/Vial } & : 1 / 1 \\ \text { Instrument Name } & : \text { HPLC } & \text { Channel } & : \text { B } \\ \text { Instrument Serial \# } & : \text { None } & \text { A/D mV Range } & : 1000 \\ \text { Delay Time } & : 0.00 \mathrm{~min} & \text { End Time } & : 94.99 \mathrm{~min} \\ \text { Sampling Rate } & : 2.5000 \mathrm{pts} / \mathrm{s} & & \\ \text { Sample Volume } & : 1.000000 \mathrm{ul} & \text { Area Reject } & : 0.000000 \\ \text { Sample Amount } & : 1.0000 & \text { Dilution Factor } & : 1.00 \\ \text { Data Acquisition Time } & : 3 / 21 / 201210: 38: 19 \mathrm{AM} & \text { Cycle } & : 1\end{array}$

Raw Data File : C:IHPLC Dataldatb001-20120321-103827.raw

Inst Method : C:IHPLC DatalSalmal2-t-Buaniline (3) from C:IHPLC Dataldatb001-20120321-103827.raw

Proc Method : C:IHPLC DatalSalmal2-t-Buaniline (3).mth from

Calib Method : C:IHPLC DatalSalmal2-t-Buaniline (3).mth from

Report Format File: C:IHPLC DatalSalmal2-t-Buaniline (3).rpt

Sequence File : C:IHPLC DatalSalmal2-t-Buaniline (3).seq

\begin{tabular}{|c|c|c|c|c|c|c|c|}
\hline $\begin{array}{c}\text { Peak } \\
\#\end{array}$ & $\begin{array}{l}\text { Time } \\
\text { [min] }\end{array}$ & $\begin{array}{l}\text { Area } \\
{[\mu \mathrm{V} \cdot \mathrm{s}]}\end{array}$ & $\begin{array}{c}\text { Height } \\
{[\mu \mathrm{V}]}\end{array}$ & $\begin{array}{c}\text { Area } \\
{[\%]}\end{array}$ & $\begin{array}{c}\text { Norm. Area } \\
{[\%]}\end{array}$ & $B L$ & $\begin{array}{l}\text { rea/Height } \\
\text { [s] }\end{array}$ \\
\hline - & 0.001 & 0.00 & 0.00 & 0.00 & 0.00 & & \\
\hline & 2.127 & 128615.60 & 11692.96 & 1.82 & 1.82 & BB & 10.9994 \\
\hline & 28.667 & 6828338.20 & 504729.01 & 96.89 & 96.89 & BB & 13.5287 \\
\hline & 83.774 & 90798.80 & 6660.49 & 1.29 & 1.29 & BB & 13.6324 \\
\hline & & 7047752.60 & 523082.47 & 100.00 & 100.00 & & \\
\hline
\end{tabular}

Missing Component Report

Component Expected Retention (Calibration File)

2-t-Buaniline (3) $\quad 0.001$ 


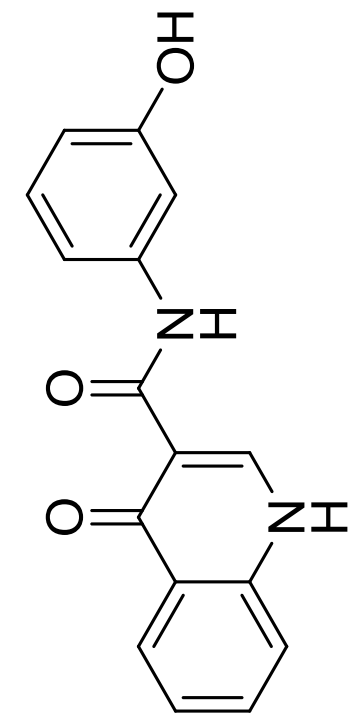

안반 


$\begin{array}{llll}\text { Software Version } & : 6.3 .2 .0646 & \text { Date } & : \text { 8/21/2012 2:40:42 PM } \\ \text { Operator } & : \text { balkhour } & \text { Sample Name } & : 3 \text {-amino } \\ \text { Sample Number } & : \text { 001 } & \text { Study } & \vdots \\ \text { AutoSampler } & : \text { SER200 } & \text { Rack/Vial } & : 1 / 1 \\ \text { Instrument Name } & : \text { HPLC } & \text { Channel } & : \text { B } \\ \text { Instrument Serial \# } & : \text { None } & \text { A/D mV Range } & : 1000 \\ \text { Delay Time } & : 0.00 \mathrm{~min} & \text { End Time } & : 94.99 \mathrm{~min} \\ \text { Sampling Rate } & : 2.5000 \mathrm{pts} / \mathrm{s} & & \\ \text { Sample Volume } & : 1.000000 \mathrm{ul} & & \\ \text { Sample Amount } & : 1.0000 & \text { Area Reject } & : 0.000000 \\ \text { Data Acquisition Time } & : 3 / 30 / 20122: 38: 03 \mathrm{PM} & \text { Dilution Factor } & : 1.00 \\ & & \text { Cycle } & : 1\end{array}$

Raw Data File : C:IHPLC Dataldatb001-20120330-143812.raw

Inst Method : C:IHPLC DatalSalmal3-amino from C:IHPLC Dataldatb001-20120330-143812.raw

Proc Method : C:IHPLC DatalSalmal3-amino.mth from

Calib Method : C:IHPLC DatalSalmal3-amino.mth from

Report Format File: C:IHPLC DatalSalmal3-amino.rpt

Sequence File : C:IHPLC DatalSalmal3-amino.seq

\section{DEFAULT REPORT}

Peak Time Area Height Area Norm. Area BL Area/Height

\begin{tabular}{|c|c|c|c|c|c|c|c|}
\hline \# & [min] & {$[\mu \mathrm{V} \cdot \mathrm{s}]$} & {$[\mu \mathrm{V}]$} & {$[\%]$} & [\%] & & [s] \\
\hline - & 0.001 & 0.00 & 0.00 & 0.00 & 0.00 & & \\
\hline 1 & 1.937 & 93436.60 & 16185.69 & 1.59 & 1.59 & BB & 5.7728 \\
\hline 2 & 19.147 & 5667494.80 & 498600.53 & 96.59 & 96.59 & BB & 11.3668 \\
\hline 3 & 83.627 & 106876.80 & 24178.85 & 1.82 & 1.82 & BB & 4.4203 \\
\hline
\end{tabular}

$5867808.20 \quad 538965.07 \quad 100.00 \quad 100.00$

Missing Component Report

Component Expected Retention (Calibration File) 


\section{References}

1) Simmonds, N.J. Cystic fibrosis and survival beyond 40 years. Ann. Respir. Med. 2011, 2 (1), 55-63.

2) Di Saint'Agnese, P.A.; Darling R.C.; Perera, G.A.; Shea, E. Abnormal electrolyte composition of sweat in cystic fibrosis of the pancreas. Pediatrics. 1953, 12 (5), 549-563.

3) Quinton, P.M. Chloride impermeability in cystic fibrosis. Nature. 1983, 301, 421-422.

4) Riordan, J.R.; Rommens, J.M.; Kerem, B.S.; Alon, N.; Rozmahel, R.; Grzelczak, Z.; Zielenski, J.; Lok, S.; Plavsic, N.; Chou, J.L.; Drumm, M.L.; Iannuzzi, M.C.; Collins, F.S.; Tsui, L.C. Identification of the cystic fibrosis gene: cloning and characterization of complementary DNA. Science. 1989, 245 (4922), 1066-1072.

5) Licht, A.; Schneider, E. ATP binding cassette systems: structures, mechanisms, and functions. Cent. Eur. J. Biol. 2011, 6 (5), 785-801.

6) Chiaw, P.K.; Eckford, P.D.W.; Bear, C.E. Insights into the mechanisms underlying CFTR channel activity, the molecular basis for cystic fibrosis and strategies for therapy. Essays Biochem. 2011, 50, 233-248.

7) Wang, W.; Okeyo, G.O.; Tao, B.; Hong, J.S.; Kirk, K.L. Thermally Unstable Gating of the Most Common Cystic Fibrosis Mutant Channel (AF508). J. Biol. Chem. 2011, 286 (49), 41937-41948.

8) Wellhauser, L.; Chiaw, P.K.; Pasyk, S.; Li, C.; Ramjeesingh, M.; Bear, C.E. A SmallMolecule Modulator Interacts Directly with $\triangle$ Phe508-CFTR to Modify Its ATPase Activity and Conformational Stability. Mol. Pharmacol. 2009, 75 (6), 1430-1438. 
9) Conese, M; Ascenzionic, F.; Boyd, A.C.; Coutelle, C.; De Fino, I.; Smedt, S.; Rejman, J.; Rosenecker, J.; Schindelhauer, D.; Scholte, B.J. Gene and cell therapy for cystic fibrosis: From bench to bedside. J. Cyst. Fibros. 2011, 10 (suppl.2), S114-S128.

10) Schwiebert, E.M.; Benos, D.J.; Egan, M.E.; Stutts, M.J.; Guggino, W.B. CFTR is a Conductance Regulator as well as a Chloride Channel. Physiological Reviews. 1999, 79 (suppl.1), S145-S166.

11) Rogan, M.P.; Stoltz, D.A.; Hornick, D.B. Cystic fibrosis transmembrane conductance regulator intracellular processing, trafficking, and opportunities for mutation-specific treatment. CHEST. 2011, 10 (139), 1480-1490.

12) McKone, E.F.; Aitken, M.L. Cystic fibrosis: disease mechanisms and therapeutic targets. Drug Discovery Today: Disease Mechanisms. 2004, 1 (1), 137-143.

13) Welsh, M.J.; Smith, A.E. Molecular mechanisms of CFTR chloride channel dysfunction in cystic fibrosis. Cell. 1993, 73, 1251-1254.

14) Pedemonte, N.; Tomati, V.; Sondo, E.; Caci, E.; Millo, E.; Armirotti, A.; Damonte, G.; Moran, O.Z.; Galietta, L.J.V. Dual Activity of Aminoarylthiazoles on the Trafficking and Gating Defects of the Cystic Fibrosis Transmembrane Conductance Regulator Chloride Channel Caused by Cystic Fibrosis Mutations. J. Biol. Chem. 2011, 286 (17), 1521515226.

15) Yu, Y.C.; Miki, H.; Nakamura, Y.; Hanyuda, A.; Matsuzaki, Y.; Abe, Y.; Yasui, M.; Tanaka, K.; Hwang, T.C.; Bompadre, S.G.; Sohma, Y. Curcumin and genistein additively potentiate G551D-CFTR. J. Cyst. Fibros. 2011, 10, 243-252.

16) Dérand, R.; Pignoux, L.B.; Becq, F. The Cystic Fibrosis Mutation G551D Alters the Non-Michaelis-Menten Behavior of the Cystic Fibrosis Transmembrane Conductance 
Regulator (CFTR) Channel and Abolishes the Inhibitory Genistein Binding Site. J. Biol. Chem. 2002, 277 (39), 35999-36004.

17) Shoseyov, D.; Cymberknoh, M.C.; Kerem, E. Could you please pass the salt? Am. J. Respir. Crit. Care Med. 2011, 183, 1444-1446.

18) Narasimhan, M.; Cohen, R. New and investigational treatments in cystic fibrosis. Ther. Adv. Respir. Dis. 2011, 5 (4), 275-282.

19) Van Goor, F.; Hadida, S.; Grootenhuis, P.D.J.; Burton, B.; Cao, D.; Neuberger, T.; Turnbull, A.; Singh, A.; Joubran, J.; Hazlewood, A.; Zhou, J.; McCartney, J.; Arumugam, V.; Decker, C.; Yang, J.; Young, C.; Olson, E.R.; Wine, J.J.; Frizzell, R.A.; Ashlock, M.; Negulescu, P. Rescue of CF airway epithelial cell function in vitro by a CFTR potentiator, VX-770. Proc. Natl. Acad. Sci.USA. 2009, 106 (44), 18825-18830.

20) Kaiser, J. New Cystic Fibrosis Drug Offers Hope, at a Price. Science. 2012, 335, 645.

21) Van Goor, F.; Straley, K.S.; Cao, D.; González, J.; Hadida, S.; Hazlewood, A.; Joubran, J.; Knapp, T.; Makings, L.R.; Miller, M.; Neuberger, T.; Olson, E.; Panchenko, V.; Rader, J.; Singh, A.; Stack, J.H.; Tung, R.; Grootenhuis, P.D.J.; Negulescu, P. Rescue of $\Delta$ F508-CFTR trafficking and gating in human cystic fibrosis airway primary cultures by small molecules. Am. J. Physiol. Lung Cell. Mol. Physiol. 2006, 290, L1117-L1130.

22) Ramsey, B.W.; Davies, J.; McElvaney, G.N.; Tullis, E.; Bell, S.C.; Drevinek, P.; Griese, M.; McKone, E.F.; Wainwright, C.E.; Konstan, M.W.; Moss, R.; Ratjen, F.; Gaudelus, I.S.; Rowe, S.M.; Dong, Q.; Rodriguez, S.; Yen, K; Ordonez, C.; Elborn, J.S. A CFTR potentiator in patients with cystic fibrosis and the G551D mutation. N. Engl. J. Med. 2011, 365 (18), 1663-1672. 
23) Pedemonte, N.; Sonawane, N.D.; Taddei, A.; Hu, J.; Moran, O.Z.; Suen, Y.F.; Robins, L.I.; Dicus, C.W.; Willenbring, D.; Nantz, M.H.; Kurth, M.J.; Galietta, L.J.V.; Verkman, A.S. Phenylglycine and Sulfonamide Correctors of Defective $\Delta$ F508 and G551D Cystic Fibrosis Transmembrane Conductance Regulator Chloride-Channel Gating. Mol. Pharmacol. 2005, 67 (5), 1797-1807.

24) Verkman, A.S.; Haggie, P.M.; Galietta, L.J.V. Application of green fluorescent proteinbased chloride indicators for drug discovery by high-throughput screening. Rev. Fluor. 2004, $1,85-98$.

25) Mills, A.D.; Yoo, C.; Butler, J.D.; Yang, B.; Verkman, A.S.; Kurth, M.J. Design and synthesis of a hybrid potentiator-corrector agonist of the cystic fibrosis mutant protein $\Delta$ F508-CFTR. Bioorg. Med. Chem. Lett. 2010, 20, 87-91.

26) Becq, F.; Mall, M.A.; Sheppard, D.N.; Conese, M.; Moran, O.Z. Pharmacological therapy for cystic fibrosis: From bench to bedside. J. Cyst. Fibros. 2011, 10 (Suppl 2), S129S145.

27) Knapp, J.M.; Wood, A.B.; Phuan, P.W.; Lodewyk, M.W.; Tantillo, D.J.; Verkman, A.S.; Kurth, M.J. Structure-Activity Relationships of Cyanoquinolines with Corrector-Potentiator Activity in $\Delta$ F508 Cystic Fibrosis Transmembrane Conductance Regulator Protein. J. Med. Chem. 2012, 55, 1242-1251.

28) Accurso, F.J.; Rowe, S.M.; Clancy, J.P.; Boyle, M.P.; Dunitz, J.M.; Durie, P.R.; Sagel, S.D.; Hornick, D.B.; Konstan, M.W.; Donaldson, S.H.; Moss, R.B.; Pilewski, J.M.; Rubenstein, R.C.; Uluer, A.Z.; Aitken, M.L.; Freedman, S.D.; Rose, L.M.; Hamblett, N.M.; Dong, Q.; Zha, J.; Stone, A.J.; Olson, E.R.; Ordonez, C.L.; Campbell, P.W.; 
Ashlock, M.A.; Ramsey, B.W. Effect of VX-770 in Persons with Cystic Fibrosis and the G551D-CFTR Mutation. N. Engl. J. Med. 2010, 363 (21), 1991-2003.

29) Thermo Fischer Scientific. http://www.piercenet.com (accessed July 20, 2012).

30) Dorman, G.; Prestwich, G.D. Benzophenone Photophores in Biochemistry. Biochemistry. 1994, 33 (19), 5661-5672.

31) Ghosh, B.; Antonio, T.; Reith, M.E.A.; Dutta, A.K. Discovery of 4-(4-(2-((5-Hydroxy1,2,3,4-tetrahydronaphthalen-2-yl)(propyl)amino)ethyl)piperazin-1-yl)quinolin-8-ol and Its Analogues as Highly Potent Dopamine D2/D3 Agonists and as Iron Chelator: In Vivo Activity Indicates Potential Application in Symptomatic and Neuroprotective Therapy for Parkinson's Disease. J. Med. Chem. 2010, 53, 2114-2125.

32) Bunce, R.A.; Nammalwar, B. 4(1H)-Quinolinones by a Tandem Reduction-AdditionElimination Reaction. Org. Prep. Proceed. Int. 2010, 42, 557-563.

33) Wu, J.C.; Wang, D.X.; Huang, Z.T.; Wang, M.X. Synthesis of Diverse N,O-Bridged Calix[1]arene[4]pyridine-C60 Dyads and Triads and Formation of Intramolecular SelfInclusion Complexes. J. Org. Chem. 2010, 75 (24), S1-S53.

34) Baker, W.R.; Cai, S.; Dimitroff, M.; Fang, L.; Huh, K.K.; Ryckman, D.R.; Shang, X.; Shawar, R.M.; Therrien, J.H. A Prodrug Approach toward the Development of Water Soluble Fluoroquinolones and Structure-Activity Relationships of Quinoline-3-carboxylic Acids. J. Med. Chem. 2004, 47 (19), 4693-4709.

35) Alkhouri, B.; Denning, R.A.; Chiaw, P.K.; Eckford, P.D.W.; Yu, W.; Li, C.; Bogojeski, J.J.; Bear, C.E.; Viirre, R.D. Synthesis and Properties of Molecular Probes for the Rescue Site on Mutant Cystic Fibrosis Transmembrane Conductance Regulator. J. Med. Chem. 2011, 54 (24), 8693-8701. 
36) Buckle, D.R.; Foster, K.A.; Taylor, J.F.; Tedder, J.M.; Thody, V.E.; Webster, R.A.B.; Bermudez, J.; Markwell, R.E.; Smith, S.A. Novel 1H-Benzimidazol-4-ols with Potent 5Lipoxygenase Inhibitory Activity. J. Med. Chem. 1987, 30 (12), 2216-2221.

37) Michellys, P.Y.; Ardecky, R.J.; Chen, J.H.; D'Arrigo, J.; Grese, T.A.; Karanewsky, D.S.; Leibowitz, M.D.; Liu, S.; Mais, D.A.; Mapes, C.M.; Rafizadeh, C.M.; Miller, K.M.O.A.R.; Rungta, D.; Thompson, A.W.; Tyhonas, J.S.; Boehm, M.F. Design, Synthesis, and Structure-Activity Relationship Studies of Novel 6,7-Locked-[7-(2alkoxy-3,5-dialkylbenzene)-3-methylocta]-2,4,6-trienoic Acids. J. Med. Chem. 2003, 46 (19), 4087-4103.

38) Alihodzic, S.; Berge, J.M.; Frydrych, C.S.V.; Kapic, S.; Palej, I. Preparation of macrolones erythromycin derivatives as antibacterial agents, W.O. Patent 0, 542, 96, May $18,2007$.

39) Cociorva, O.; Li, B.; Szardenings, K.; Fukuda, Y.; Nomura, M.; Seto, S.; Yumoto, K.; Okada, K.; Nakamura, A. Preparation of aminoquinolones as GSK-3 inhibitors, W.O. Patent, 1, 065, 37, Sep. 20, 2007.

40) Bartkovitz, D.J.; Chen, Y.; Chu, X.; Luk, K.; Rossman, P.L.; So, S. Preparation of 4amino-thieno[3,2-c]pyridine-7-carboxylic acid derivatives as cRaf kinase inhibitors for the treatment of cancer, U.S. Patent, 0, 060, 607, Mar. 15, 2007.

41) Sevenard, D.V.; Vorobyev, M.; Sosnovskikh, V.Y.; Wessel, H.; Kazakova, O.; Vogel, V.; Shevchenko, N.E.; Nenajdenko, V.G.; Lork, E.; Röschenthaler, G.V. Halogenation of fluorinated cyclic 1,3-dicarbonyl compounds: new aspects of synthetic application. Tetrahedron. 2009, 65, 7538-7552. 
42) Kessler, W.R.; Andersen, D.H. Heat prostration in fibrocystic disease of the pancreas and other conditions. Pediatrics. 1951, 8, 648-656.

43) Banerji, B.; Conejo-Garcia, A.; McNeill, L.A.; McDonough, M.A.; Buck, M.R.G.; Hewitson, K.S.; Oldham, N.J.; Schofield, C.J. The inhibition of factor inhibiting hypoxiainducible factor (FIH) by $\beta$-oxocarboxylic acids. Chem. Commun. 2005, 43, 5438-5440.

44) Stern, E.; Muccioli, G.G.; Millet, R.; Goossens, J.F.; Farce, A.; Chavatte, P.; Poupaert, J.H.; Lambert, D.M.; Depreux, P.; Henichart, J.P. Novel 4-Oxo-1,4-dihydroquinoline-3carboxamide Derivatives as New CB2 Cannabinoid Receptors Agonists: Synthesis, Pharmacological Properties and Molecular Modeling. J. Med. Chem. 2006, 49, 70-79.

45) Young, C.R.; Rowe, C.W. Pharmaceutical solutions containing N-(5-hydroxy-2,4-di-tertbutyl-phenyl]-4-oxo-1H-quinoline-3-carboxamide and PEG and PVP K30 for the treatment of CFTR related diseases. W.O. Patent, 134279, Nov. 22, 2007.

46) Blatt, A. H. Org. React. 1942, 1.

47) Stern, E.; Muccioli, G. G.; Millet, R.; Goossens, J. F.; Farce, A.; Chavatte, P.; Poupaert, J. H.; Lambert, D. M.; Depreux, P.; Henichart, J. P. Novel 4-Oxo-1,4-dihydroquinoline3-carboxamide Derivatives as New CB2 Cannabinoid Receptors Agonists: Synthesis, Pharmacological Properties and Molecular Modeling. J. Med. Chem. 2006, 49(1), 70-79.

48) Goldsworthy, J.; Ross, W. J.; Verge, J. P. Quinolone derivatives and their use as pharmaceuticals. Eur. Patent, 55068, Jun. 30, 1982.

49) Ueda, S.; Nagasawa, H. Copper-Catalyzed Synthesis of Benzoxazoles via a Regioselective C-H Functionalization/C-O Bond Formation under an Air Atmosphere. $J$. Org. Chem. 2009, 74(11), 4272-4277. 
50) Pasquini, S.; Botta, L.; Semeraro, T.; Mugnaini, C.; Ligresti, A.; Palazzo, E.; Maione, S.; Di Marzo, V.; Corelli, F. Investigations on the 4-quinolone-3-carboxylic acid motif. 2. synthesis and structure-activity relationship of potent and selective cannabinoid-2 receptor agonists endowed with analgesic activity in vivo. J. Med. Chem. 2008, 51(16), $5075-5084$. 